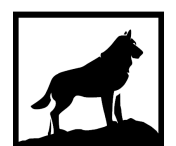

Michigan

Technological

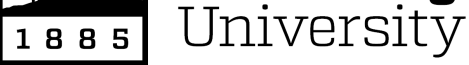

Michigan Technological University

Digital Commons @ Michigan Tech

Personality over Policy: A Comparative History of the Founding and Early Development of Four Significant American Manuscript Repositories of Business, Industry, and Technology

Erik Nordberg

Michigan Technological University, enordber@mtu.edu

Copyright 2017 Erik Nordberg

Recommended Citation

Nordberg, Erik, "Personality over Policy: A Comparative History of the Founding and Early Development of Four Significant American Manuscript Repositories of Business, Industry, and Technology", Open Access Dissertation, Michigan Technological University, 2017.

https://doi.org/10.37099/mtu.dc.etdr/527

Follow this and additional works at: https://digitalcommons.mtu.edu/etdr

Part of the History Commons 


\title{
PERSONALITY OVER POLICY: A COMPARATIVE HISTORY OF THE FOUNDING AND EARLY DEVELOPMENT OF FOUR SIGNIFICANT AMERICAN MANUSCRIPT REPOSITORIES OF BUSINESS, INDUSTRY, AND TECHNOLOGY
}

\author{
By \\ Erik C. Nordberg \\ A DISSERTATION \\ Submitted in partial fulfillment of the requirements for the degree of \\ DOCTOR OF PHILOSOPHY \\ In Industrial Heritage and Archaeology
}

MICHIGAN TECHNOLOGICAL UNIVERSITY 2017

Copyright Erik C. Nordberg 2017 
This dissertation has been approved in partial fulfillment of the requirements for the degree of DOCTOR OF PHILOSOPHY in Industrial Heritage and Archaeology.

Department of Social Sciences

Dissertation Advisor: Terry S. Reynolds

Committee Member: Susan R. Martin

Committee Member: Steven A. Walton

Committee Member: Robert R. Johnson

Department Chair: Hugh S. Gorman 


\section{TABLE OF CONTENTS}

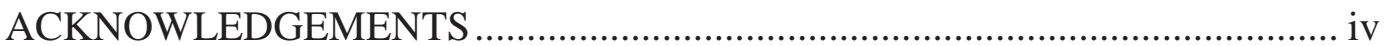

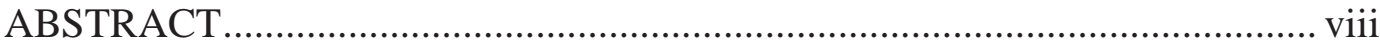

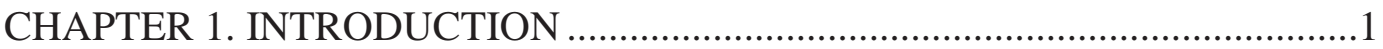

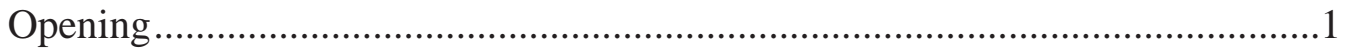

A Brief History of Manuscript Collecting Practices ..........................................4

A Brief History of the Emergence of Business History and

Manuscript Collections in Business, History, and Technology .............13

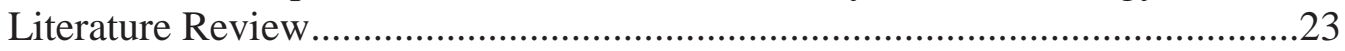

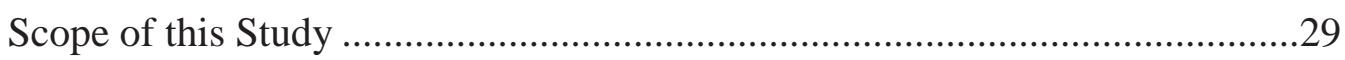

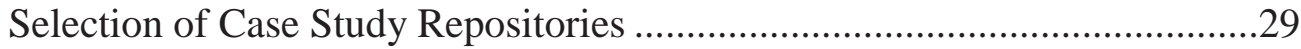

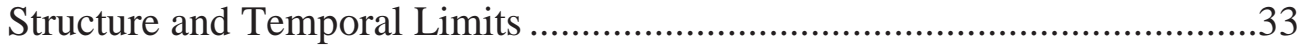

Methodology and Comparative Themes .......................................................34

Comment on Source Material ........................................................................35

CHAPTER 2. FOUNDING AND EARLY DEVELOPMENT OF

MANUSCRIPT COLLECTIONS AT BAKER LIBRARY, HARVARD

UNIVERSITY, BOSTON, MASSACHUSETTS, 1908-1980 ..................38

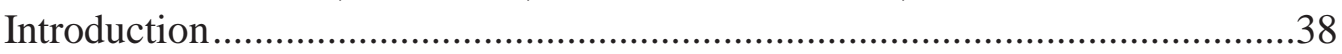

Creation of the Baker Library, 1908-1927.....................................................42

Rapid Expansion of Manuscript Collections, 1927-1956 ...............................51

Maturity and Stabilization, 1956-1980 …................................................75

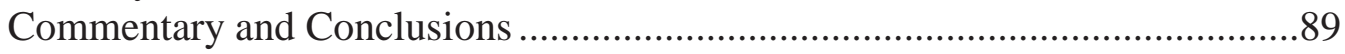

\section{CHAPTER 3. FOUNDING AND EARLY DEVELOPMENT OF}

MANUSCRIPT COLLECTIONS AT HAGLEY LIBRARY AND

MUSEUM, WILMINGTON, DELAWARE, 1953-1982 ........................96

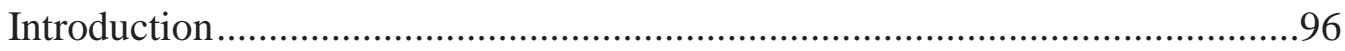

Creation of The Longwood Library and The Hagley Museum, 1953-1961 ......97

The Longwood Library ..............................................................................98

The Hagley Museum and Records of the DuPont Company .......................107

Non-DuPont Business and Industrial Manuscripts Before Consolidation...114

Consolidation of The Longwood Library and The Hagley Museum...........121

Rapid Expansion of Manuscript Collections, 1961-1982 _..............................129

Maturity and Stabilization, 1982 to Present..................................................161

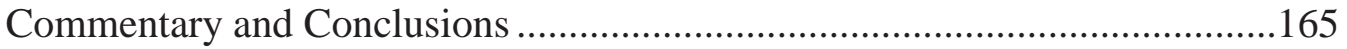




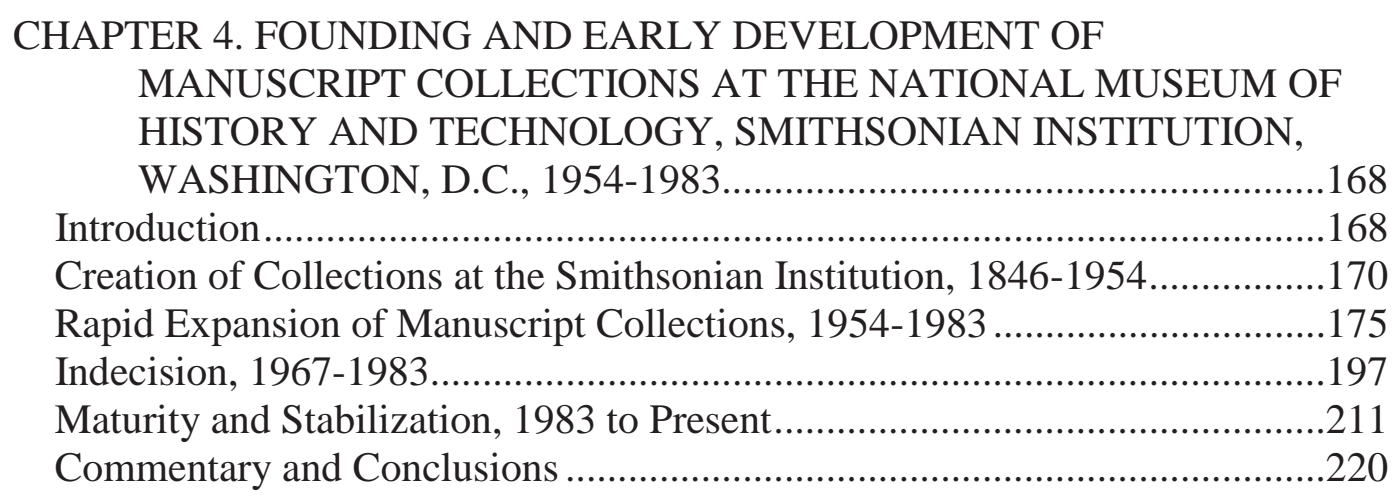

CHAPTER 5. FOUNDING AND EARLY DEVELOPMENT OF MANUSCRIPT COLLECTIONS AT THE BENSON FORD RESEARCH CENTER, THE HENRY FORD DEARBORN, MICHIGAN, 1905-1983 ........................225

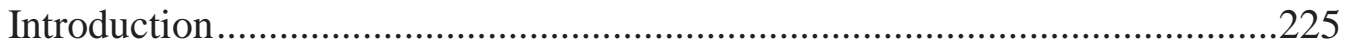

Creation of Manuscript Collections at the Edison Institute, 1905-1964...........227

Creation and Rapid Expansion of the Ford Motor Company

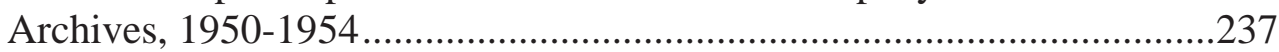

Disinterest, Disinvestment, and Disposal of the Ford Motor Company Archives, 1954-1964 ...............................................................266

Combined Collections at the Henry Ford Museum, 1964-1983 .......................282

Commentary and Conclusion..........................................................................297

CHAPTER 6. COMMENTARY AND CONCLUSIONS .....................................304

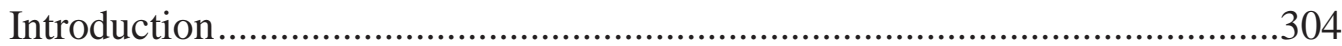

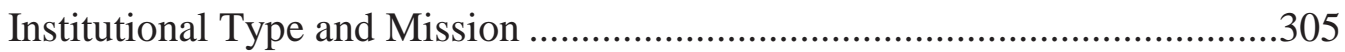

Models Used ...................................................................................................

Organizational Structures and Staffing ...............................................................316

Collection Policies and Appraisal/Acquisition Systems....................................324

Facilities and Space....................................................................................326

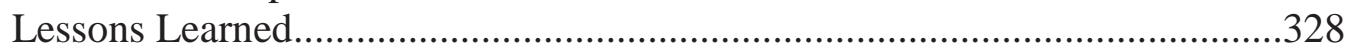

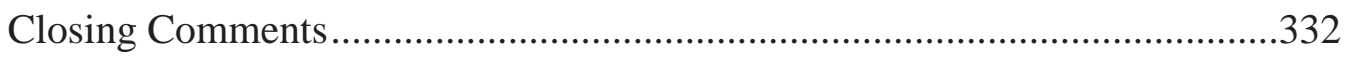

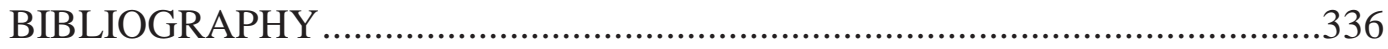




\section{LIST OF TABLES}

Table 1.1 Overview of Case Study Repositories ...............................................31

Table 2.1 Growth of Collections, Baker Library, 1932-2017 ............................84

Table 3.1 Growth of Collections, Hagley Library, 1955-2017.........................162

Table 4.1 Tabulations of Collections Held in MHT Divisions

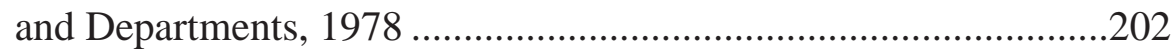

Table 4.2 Growth of Collections, MHT, 1965-2011 ...................................219

Table 5.1 Growth of Collections, Ford Archives, 1951-2017 .295 


\section{ACKNOWLEDGEMENTS}

This project is the culmination of a long journey. Certainly the last nine years, through my doctoral coursework, examinations, research, and writing. But my inspiration came in many forms at many moments. Some from my childhood, when my engineer father instilled an interest in history, historical places, and mechanical things. I recall our visit to the Quincy Mine in Hancock during my teenage years and our mutual amazement upon finding our family name forged into joists of the giant steam hoisting engine constructed by the Nordberg Manufacturing Company of Milwaukee, Wisconsin. My route back to the Keweenaw wasn't through industrial history, but as an archivist charged with selecting and preserving historical records. And it was while working at the Michigan Tech Archives that I found its collection of blueprints from the Nordberg Manufacturing Company. Over time, I learned that these materials were once part of a larger collection of records created and held by the company, that they had been surveyed by curators from Smithsonian Institution, and that the collection had been broken into pieces and transferred to repositories around the country. This was the original kernel for this project: Which are the most important archival repositories collecting records of business, industry, and technology? How and why did they begin collecting manuscripts? What influenced what they collected? What did they turn down (and what happened to that stuff)? Is there enough historical archival material preserved to answer the myriad of questions we have (and will have) about business, industry, and technology?

It may not seem much of a surprise to find an archivist writing about archives. But there is actually very little research into the history of archival repositories. The study of archival history is challenging, ironically, because archivists are not great record-keepers about our own history. We devote most of our available resources to caring for the records of other people, organizations, and corporations, treating our own administrative records as little more than necessary bureaucratic reports. We tend to be suspicious about doctoral researchers asking questions about how and why we made the choices we did, especially if those choices resulted in the destruction of historical records (even if those 
records were not within our repository's specific collecting scope). Access may understandably be denied to donor case files and accession records, which often include purchase prices and other confidential materials. Suspicions may be heightened when the doctoral researcher behind the study is also an archivist at a 'competing' institution. Add to this the author's stated intention to compare and contrast practice at multiple institutions - and to share the analysis publicly - and one can imagine an increased level of hesitation. Sadly, in some cases, these anxieties resulted in denied access to internal records and disinterest in personal interviews about historical practice. Not only was this frustrating to this doctoral archivist researcher, but it ultimately limits how much our profession can learn from its own history and how much it can improve its future activity.

Thankfully, this study was supported by many archivists, librarians, and museum curators with an interest in transparency and a welcoming attitude to the project. A full list of the individuals who participated in personal interviews is included in the bibliography, but I am particularly grateful to John Fleckner, Robert Vogel, John White, and Barney Finn at Smithsonian, Chris Baer and Lynn Catanese at Hagley, and Judith Endelman, Terry Hoover, Cynthia Read Miller, Brian Wilson, and Linda Skolarus at The Henry Ford.

During this research, I was welcomed by a group of archival scholars who meet annually at the Archives Education and Research Institute. These meetings provided a platform to test my content in front of a patient and forgiving audience, and receive valuable feedback from the leading experts in the field. More importantly, though, was finding a cohort of fellow dissertators sharing similar journeys in other programs. This GED group ("Get "er Done") urged me on, shared my successes, and lamented my struggles. My sincere thanks to Jenny Stevenson $(\mathrm{PhD})$ in Milwaukee, Eliot Wilczek $(\mathrm{PhD})$ in Boston, Katie Pierce in Austin, Jonathan Dorey in Montreal, Snowden Becker and Dalena Hunter in Los Angeles, Anastasia Weigle in Maine, and Chris Colwell down under in Sydney. We were never together in one space for any length of time, but the internet is a magic thing.

I also want to acknowledge my extended Michigan Tech, Copper Country, and work families. During my 18 years in Houghton, lines were blurred between faculty, 
fellow students, professional colleagues, and personal friends. I'm certainly thankful to my committee: Susan Martin, Steve Walton, Bob Johnson, and chair Terry Reynolds. While impossible to name everyone, I would be remiss if I failed to also mention Patrick Martin, Bruce Seely, Larry Lankton, Carol MacLennan, Kim Hoagland, Lee Presley, Scott See, Sean Gohman, and Paul White. I have been lucky to work with a myriad of cool people who held down the fort while I was distracted with thoughts of industrial archives. These include Christine Holland and Beth Russell at the Michigan Tech Archives, Robbe DiPietro and Karen Rhodes at the Michigan Humanities Council, members of the "Breakfast Club" (Virginia Thomas, Sandra Martin, and Paul Gallagher) and Sandy Yee at Wayne State, and Brandon Carter at the Reuther Library. Jo Urion and Sue Scanlan continue as true blue friends. My one regret is that I didn't finish in time for Tom Scanlan to buy me a congratulatory beer; his supportive smile and questions about "the big D" kept me focused on getting this dissertation done.

Finally, there is my real family. My mother and father, Darlene and Gary Nordberg, raised me right and have supported me at every step. I developed my love of history through AAA TripTiks and guidebooks, family subscriptions to National Geographic and Arizona Highways, and countless trips to historic sites as far flung as Colonial Williamsburg, the walled city of Luxembourg, Cape Canaveral, Michigan's Copper Country, and the historic Bushmills Distillery in Northern Ireland (I particularly liked that one). Their generosity and love continues to inspire me.

This work could not have been possible, however, without the steadfast support of two individuals who understood what I was trying to do, constantly reminded me why this work was important, and why I was the person to do it. Dr. Terry Reynolds has served as my dissertation advisor, faculty member, mentor, editor, academic colleague, and friend. I still feel a bit of an imposter about this whole thing, but it was Terry's reassuring and supportive tone - as well as the occasional "gentle inquiry" about my intentions to continue - which kept me on track to finish. It is typical of Terry's character that he continued this support - with increasing commitments of his personal time and finances - even into retirement. 
Jane Nordberg, my best friend and also my wife, has been with me every step of the way. She provided encouragement when I was on the struggle bus, applied an external editorial eye to my awkward prose (and the occasional Scooby Doo sticker if a draft chapter passed muster), and donated large portions of our 'together time' to the research, writing, and conference needs of a multi-year dissertation project. It is impossible to adequately acknowledge, appease, atone, and apologize for all of the doctoral hoopla these recent years. At the end of the day, however, it will always be just the two of us Sunday driving, not arriving, with your limitless undying love shining around me like a million suns. 


\section{ABSTRACT}

Personality over Policy: A Comparative History of the Founding and Early Development of Four Significant American Manuscript Repositories of Business, Industry, and Technology

\section{Erik C. Nordberg}

This dissertation compares and contrasts the founding and early manuscript collecting activities of four publicly accessible American archival repositories known for their extensive holdings in business, industrial, and technological history: the Baker Library at Harvard University in Boston, Massachusetts; the Hagley Library and Museum in Wilmington, Delaware; the Archives Center at the National Museum of American History in Washington, D.C.; and the Benson Ford Research Center at the Henry Ford museum in Dearborn, Michigan. It uses a historical narrative methodology and case study approach to consider how institutional contexts influenced appraisal and selection activities at these repositories during their formative years 1905-1983. The contexts considered include institutional mission, anticipated users, models inspiring their initial work, partner agencies and networks that supported their collecting activities, and the education and training of their staff. This study analyzes how these contexts affected the manuscript collections available for research today and why other records were ignored, passed over, or destroyed.

The first chapter situates the histories of these four case study institutions within the larger contexts of the history of libraries, museums, and archives in the United States, the expansion of interest in business history in the twentieth century, and existing literature about archival practice at institutions which collect manuscript records in business, industry, and technology. Chapters 2 through 5 examine each of the four case study institutions in detail, documenting their establishment, periods of rapid expansion, and ultimate stabilization. Chapter 6 provides comparative commentary and analysis. The study reveals the idiosyncratic nature of manuscript collecting at the four repositories. Acquisition was not guided by pre-established policies or guidelines at any of the four repositories, nor did the repositories have a standardized approach. Instead key individuals at each institution determined the direction of manuscript acquisition, usually in an ad hoc manner. Personality took primacy over written policy. The separate and often disparate approaches that resulted, however, led to the preservation of a much broader range of record formats, business types, and industrial sectors than might otherwise have survived. 


\section{CHAPTER 1. INTRODUCTION}

\section{Opening}

It is difficult to overstate the importance of business, industry and technology to our understanding of American history. Manufacturing and industrial production has defined a significant portion of the nation's economy, attracted and employed millions of immigrants, and influenced the United States' role in international commerce and politics. Business, industry, and technology have been topics of study for historians and academicians for some time, but in recent decades the general public began to embrace these fields as important and valuable aspects of our shared heritage. This public interest has given rise to attempts to preserve aspects of former industrial sites such as historic textile mills in Lowell, Massachusetts; steel towns in Pennsylvania; aspects of the automobile industry near Detroit; and the remains of Upper Michigan's historic copper mining district.

Records preserved in archives and records centers, however, are necessary supplements to the physical remains - the former industrial buildings, the worker housing, and the cultural landscape. In many cases, these records are the only surviving evidence of specific business enterprises; the factories or manufacturing facilities they document have been removed from the landscape or made unrecognizable by Brownfield redevelopment into recreational areas, condominium complexes, or retail strip malls. Unpublished manuscripts thus play a critical role in understanding and studying industrial history. These records may include personal papers, administrative correspondence, financial records, technical reports, labor and production records, engineering drawings, oversize maps, and photographs. They are used by historians to examine sites, the built environment, industrial processes, the methods of business (and of businessmen and women), the creativity of individual engineers, and the application of technologies to industrial problems. In some cases, they can be used as material culture artifacts to 
capture evidence of their creators and users, such as relationships between design engineers and shop floor fabricators. ${ }^{1}$

Few scholars question the value of archival records to historians and other researchers. Articles drawing on such records to explore aspects of the history of business, industry, and technology regularly appear in professional journals such as Technology and Culture (Society for the History of Technology), Enterprise and Society (Business History Conference), The Business History Review (Harvard Business School) and IA, The Journal of the Society for Industrial Archeology. Monographic studies also draw from archival business records, such as Anthony Wallace's St. Clair, Gail Cooper's Air Conditioning America, Larry Lankton's research into Michigan's historic copper mining district in Beyond the Boundaries and Cradle to Grave, and Kenneth Warren's Big Steel. Manuscript records are important remnants of industrial heritage, of equal scholarly value to artifacts, buildings, sites, and the oral reminiscences of those directly engaged in these activities. ${ }^{2}$

Although heavy industry and manufacturing have been in decline in the United States, many larger corporations, such as General Motors, John Deere, Eli Lilly, and the Weyerhaeuser Company, hold historical materials. While directories of business archives hint at the number of collections held privately by these and other corporations, it is often difficult to assess the content, comprehensiveness, and potential value of these collections. Unfortunately, a variety of forces discourage active corporations from

\footnotetext{
${ }^{1}$ John Brown, "When Machines Became Gray and Drawings Black and White: William Sellers and the Rationalization of Mechanical Engineering." IA, 25:2 (1999), 29-54.

${ }^{2}$ Anthony Wallace, St. Clair: A Nineteenth-Century Coal Town's Experience with a Disaster-prone Industry (New York: Knopf, 1987); Gail Cooper, Air Conditioning America: Engineers and the Controlled Environment, 1900-1960 (Johns Hopkins University Press, 1998); Larry Lankton, Beyond the Boundaries: Life and Landscapes at the Lake Superior Copper Mines, 1840-1875 (New York: Oxford University Press, 1997) and Cradle to Grave: Life, Work, and Death at the Lake Superior Copper Mines (New York: Oxford University Press, 1991); and Kenneth Warren, Big Steel: The First Century of the United States Steel Corporation (Pittsburgh: University of Pittsburgh Press, 2001). Examples of journal articles include Silvio Bedini, "The Evolution of Science Museums," Technology and Culture, 6:1 (Winter 1965) 1-29; Mary Yeager, "Mavericks and Mavens of Business History: Miriam Beard and Henrietta Larson," Enterprise and Society, 2:4 (December 2001), 687-768; Philip Scranton, "Diversity in Diversity: Flexible Production and American Industrialization, 1880-1930," Business History Review, 65:1 (April 1991), 27-90; and Helena Wright, "Insurance Mapping and Industrial Archaeology," IA, 9:1, (1983), 1-18.
} 
retaining or sharing these records, including patent secrecy, fear of exposure to litigation, and a desire to control brand messaging. In some cases, however, corporations have provided special access to historical researchers including Carlos Schwantes' history of the Phelps Dodge Corporation, Charles Hyde's work on the Chrysler Corporation, and Terry Reynolds and Virginia Dawson's study of the Cleveland-Cliffs Iron Company. More often, however, scholars and the general public are prohibited from accessing this material, and it is unclear if certain types of sensitive, embarrassing, or controversial material are preserved at all. ${ }^{3}$

Fortunately, researchers may access some significant collections that have been preserved at a number of key institutions. This dissertation compares and contrasts the founding and early manuscript collecting activities of four publically accessible American archival repositories known for their extensive holdings in business, industrial, and technological history: the Baker Library at Harvard University in Boston, Massachusetts; the Hagley Library and Museum in Wilmington, Delaware; the Archives Center at the National Museum of American History in Washington, D.C.; and the Benson Ford Research Center at the Henry Ford museum in Dearborn, Michigan. While business records date back to antiquity, institutions that have collected them and developed means of processing and retrieving them for the use of historians, preservationists, and others are of more recent vintage. To introduce this study, it is useful to situate the histories of these four case study institutions within larger contexts, such as the history of libraries, museums, and archives in the United States, the expansion of interest in business history in the twentieth century, and existing literature about

\footnotetext{
${ }^{3}$ Elizabeth Adkins provides a listing of corporate archives at more than forty large U.S. firms and notes with many she contacted "requests for access were usually denied because of proprietary concerns, or they were stymied by the sheer volume of unprocessed records stored in warehouses that were inaccessible even to the corporate owners. Many other records were thrown away in an effort to reduce storage costs, and thus were lost forever to both historians and corporate management." See Elizabeth Adkins, "The Development of Business Archives in the United States: An Overview and a Personal Perspective." The American Archivist, 60 (Winter 1997), 8-33. See also Carlos Schwantes, Vision \& Enterprise: Exploring the History of Phelps Dodge Corporation (Phoenix: University of Arizona Press, 2000); Charles Hyde, Riding the Roller Coaster: A History of the Chrysler Corporation (Detroit: Wayne State University Press, 2003); Terry Reynolds and Virginia Dawson, Iron Will: Cleveland-Cliffs and the Mining of Iron Ore, 1847-2006 (Detroit: Wayne State University Press, 2011).
} 
archival practice at institutions which collect manuscript records in business, industry, and technology. An understanding of the history of archives and libraries, as well as the evolution of the specific practice in these topical areas, provides the contexts within which the case study institutions operated - and which shaped their selection and preservation of significant manuscript resources documenting industrial heritage topics.

\section{A Brief History of Manuscript Collecting Practices}

The four repositories studied in this dissertation operated within, and sometimes across, a range of library, museum, and archival functions and interacted through external partnerships with scholars of business, industrial, technological, and economic history. Thus, we will briefly review the general historical development of manuscript collecting practices in libraries, archives, and museums.

The basic concepts of selecting, preserving, organizing, classifying, describing, and providing access to objects and recorded information date to ancient times. The antecedents of modern museums are the "cabinet collections" and "wonder rooms" of objects and historical artifacts gathered by royalty, scholars, and wealthy landowners in the sixteenth and seventeenth centuries. Although space discourages a detailed analysis, libraries and museums became a mainstay of American cultural history in the nineteenth century with the establishment of institutions such as the Library of Congress (founded 1800, though only achieving size and importance in the 1870s), the Smithsonian Institution (1846/building opened 1855), the Boston Public Library (1848/1895), New York's Metropolitan Museum of Art (1870/1872), the American Museum of Natural History (1869/1874), the Art Institute of Chicago (1879/1893), and the New York Public Library (1895/1911). ${ }^{4}$

\footnotetext{
${ }^{4}$ Fred Lerner, The Story of Libraries: From the Invention of Writing to the Computer Age (New York: Continuum, 1999), 107-120, and Richard Rubin, Foundations of Library and Information Science (New York: Neal Schuman, 1998), 207-264. Other key museum institutions might include the Detroit Institute of Arts (1885/1927), Chicago's Field Museum (1893/1921), the Cleveland Museum of Art (1913/1916), and the National Gallery of Art (1937/1941). See also Edward Alexander, Museums in Motion: An Introduction to the History and Function of Museums (Nashville, Tenn.: American Association for Local History, 2008); Kenneth Hudson, A Social History of Museums (Atlantic Highlands, NJ: Greenwood Press, 1975); and Oliver Impey and Arthur MacGregor, editors, The Origins of Museums: The Cabinets
} 
In the late nineteenth-century library professionals first developed consistent policies and procedures to select, arrange and describe collections. Formal systems of controlled vocabulary and descriptive subject heading thesauri (the most popular being the Library of Congress Subject Headings, developed in 1897) came together in the form of card catalogs and shared rules for description. The need to train individuals in library techniques encouraged the creation of library education programs, such as the first at Columbia University in 1887. Library training programs remained primarily undergraduate or "fifth-year degrees" through the 1920s, when the Carnegie Foundation supported creation of a new graduate department for library studies (and the first-ever PhD program) at the University of Chicago in 1928. The American Library Association began accrediting library science graduate programs in the $1950 \mathrm{~s}^{5}$

Librarians also formed membership associations earlier than archival and museum disciplines. These quickly diversified into a variety of specialist organizations. The American Library Association (ALA), established in 1876, remains the umbrella; specialized associations include the Association of State Library Agencies (1889), the American Association of Law Libraries (1906), the Special Libraries Association (1909), and the Association of American Library Schools (1911). Through conferences and workshops, these library associations informed members about practice in the field. Associated publications programs worked to create a body of theory and knowledge, particularly through periodicals like Library Journal (1876), American Libraries (1907),

of Curiosities in Sixteenth- and Seventeenth Century Europe (Oxford: Clarendon Press, 1983). For additional background on the history of museums, see Warren Leon and Roy Rosenzweig, editors, History Museums in the United States: A Critical Assessment (Urbana: University of Illinois Press, 1989) and Edward Alexander, Museum Masters: Their Museums and Their Influence (Walnut Creek, Calif.: AltaMira Press, 2002).

${ }^{5}$ By 1901, the authority of the Library of Congress as primary source for cataloging was so firmly established that it began selling copies of catalog cards to other libraries for use in their local card catalogs. See Lerner, The Story of Libraries, 135; Rubin, Foundations, 217-220; Richard Berner, Archival Theory and Practice in the United States: A Historical Analysis (Seattle: University of Washington Press, 1983), 18; and John Fitzpatrick, Notes on the Care, Cataloguing, Calendaring and Arranging of Manuscripts (Washington, D.C.: Government Printing Office, 1913). Today more than fifty graduate programs of Library and Information Science are operating in the United States and Canada. There is no centralized certification program for librarians, although some specializations in medical and school libraries have established systems for voluntary credentialing and professional development. See Rubin, Foundations, 254. 
and peer-reviewed scholarly journals such as Library Quarterly, (1931) and Library Trends (1952). ${ }^{6}$

Museum practitioners faced greater challenges than librarians in establishing formal policies and procedures for their work. With a wide range of thematic missions everything from cultural history to natural history, from art to living history villages, and from children's museums to museums of science and technology - museum staff found it much more difficult to establish common standards. Nonetheless, as with librarians, a variety of membership associations supported their work, providing training, networking, and publications. The American Association for State and Local History (AALSH), established initially in 1904 as part of the American Historical Association, provided networking for historical museums. The American Association of Museums (now the American Alliance of Museums, AAM), founded in 1906, emerged shortly after to share evolving forms of practice more broadly, through publications like Museum Work (1918) and Museum News (1924). The diversity of topical missions, however, fractured museum literature across an expanding universe of subject-specific associations and publications. Journals in museum studies, such as Curator, created in 1958 by the American Museum of Natural History, and the Journal of Museum Education, first published in 1973 by the Museum Education Roundtable, reflect this specialization and segregation by topic. ${ }^{7}$

Museums have historically preferred staff educated in specific topical disciplines, and major institutions have often required the $\mathrm{PhD}$ for their specialist curators. In more recent times, however, a wider range of interpretive and educational specialists have leavened the roles played by subject experts. Academic museum studies programs, offering degrees at the master's level, emerged in the 1970s. Although AAM developed a

\footnotetext{
${ }^{6}$ Peggy Sullivan, “Library Associations," Library Trends, 25:1 (July 1976), 135-152; and Periam Danton, “The Library Press," Library Trends, 25:1 (July 1976), 153-176.

7 Jay Rounds, "Is There a Core Literature in Museology?," Curator, 44:2 (April 2001), 194-206 and "On the Uses of Museum Studies Literature: A Research Agenda," Curator, 50:1 (January 2007), 135-146; John East, "Searching the Museum Studies Journal Literature," Curator, 51:3 (July 2008), 311-317; Hugh Genoways, "Museum Studies Programs Are Not Prepared for the Ph.D," Curator, 39:1 (March 1996), 6-11.
} 
set of best practices for museum professional training, it did not develop a formal system of educational program review and accreditation to give the practices clout. ${ }^{8}$

Traditionally, libraries and museums have emphasized an item-level approach to arrangement and description of collections. During the latter half of the nineteenth century, librarians developed key systems to organize content and knowledge, particularly classification schemes for physically shelving materials by subject, such as the Dewey Decimal Classification system, first proposed in 1876, and the more detailed Library of Congress Classification system, developed in 1897. Museum curators developed similar item-level approaches to the systematic arrangement, classification, and description of their holdings. Some museums, particularly those collecting geological and natural history specimens, sought to be build complete "systematic" collections, with representative samples from each branch of a classification schema. While both libraries and museums serve public interests, museums also exhibit their holdings for interpretive and educational purposes, often allowing such needs to influence collecting priorities. ${ }^{9}$

Archival work, that is, the preservation and organization of historical documents, emerged early in civilized states, and many of the earliest known "records" are inventory and sales records from ancient business activity. Manuscript materials were often collected by libraries and museums, which often treated documents similarly to books or artifacts, or bound documents together to be treated like books. During the nineteenth century, prominent collections of American historical documents were sometimes gathered in special libraries of membership societies, such as the American Philosophical Society of Philadelphia (founded in 1743) and the Essex Institute at Salem,

\footnotetext{
${ }^{8}$ Stephen Weil, Rethinking the Museum and Other Meditations (Washington, D.C.: Smithsonian Institution, 1990), 73-89; Jackie Weisz, Codes of Ethics and Practice of Interest to Museums (Washington, D.C.: American Association of Museums, 2000); Gary Edson, International Directory of Museum Training (London: Routledge, 1995); Elizabeth Schlatter, Museum Careers: A Practical Guide for Students and Novices (Walnut Creek, Calif.: Left Coast Press, 2008), 123-135; Constance Schulz, American Historical Association, and National Council on Public History, Careers for Students of History (Washington, D.C.: American Historical Association, 2002).

${ }^{9}$ For medical publications, the late 1870s saw the creation of descriptive index cards, the Index-Catalog of the Surgeon-General's Library and the first publication of Index Medicus. See Berner, Archival Theory and Practice, 18; and Fitzpatrick, Notes on the Care, Cataloguing, Calendaring and Arranging of Manuscripts.
} 
Massachusetts (1848), or gathered by wealthy individuals and converted into public research facilities, such as the Henry Huntington Library in San Marino, California (1919), or the Clarence Burton Collection at the Detroit Public Library (1915). The development of a separate theory and practice for archival administration, however, is relatively recent. Most of the major concepts in the field, including provenance, original order, the concept of record series, and of hierarchal relations between records (described below), have only been formally recognized by American archivists in the last half century. ${ }^{10}$

The American archival profession was initially encouraged by historians and historical organizations, including the Historical Manuscripts Commission (1895), the Public Archives Commission (1899), and the Conference of Archivists (1909) - all three created or sponsored by the American Historical Association (AHA). During the 1930s, archivists developed their own separate identity through the establishment of the United States National Archives (1934), initiation of the Historical Records Survey of the Works Progress Administration (1935), founding of the Society of American Archivists (SAA) (1936), and debut of the discipline's preeminent scholarly journal, SAA's The American Archivist (1938). ${ }^{11}$

Through the 1950s, archival practitioners acknowledged a tension between two approaches for arranging and describing records, a tension we will see in several of the repositories investigated in this study. The first (and earlier) historical manuscripts tradition originated in museums, private libraries, and historical societies, where nongovernmental agencies collected private papers of individuals, often the 'great men' of the world. These repositories initially dealt with small collections of manuscript material and, in some cases, individual documents bound together into volumes. These circumstances encouraged an item-level approach to description, following established

\footnotetext{
${ }^{10}$ Lucille Kane, "Manuscript Collecting," in William Hesseltine, editor, In Support of Clio; Essays in Memory of Herbert A. Kellar (Madison: State Historical Society of Wisconsin, 1958), 35-36.

${ }^{11}$ Berner, Archival Theory and Practice, 13-23; Terry Cook, "What is Past is Prologue: A History of Archival Ideas Since 1898, and the Future Paradigm Shift," Archivaria, 43 (Spring 1997), 17-63; Richard Cox, "American Archival History: Its Development, Needs, and Opportunities," The American Archivist, 46:1 (Winter 1983), 31-41; and James O'Toole, Understanding Archives and Manuscripts (Chicago: Society of American Archivists, 1990).
} 
library cataloging and calendaring systems for books and journals. The item-level approach was also initially encouraged by the Library of Congress' Notes on the Care, Cataloguing, Calendaring and Arranging of Manuscripts, which was published in 1913 and reprinted through the 1930s. ${ }^{12}$

A second public archives tradition or archives approach grew from handling public governmental records, including the more voluminous collections of large bureaucratic entities. This approach considered the full life cycle of records, including large blocks of routine operational records, which required active management, appraisal, and selection - as well as disposal of large blocks of materials with no lasting historical value. Drawing from the historian's concern with the sources of information, the archives approach adopted as fundamental the concepts of provenance and original order - the French phrase respect des fonds - dictating that records from different creators be maintained separately and retain each creator's original arrangement scheme. In this approach, descriptive finding aids with detailed inventories described the hierarchical relationships of series of records within a collection. The public archives system utilized a 'top down' approach, completing description at the collection level first, with inventories only describing records to series or folder level, and only very rarely describing individual documents at the item level. ${ }^{13}$

Key developments in the 1950s and 1960s pushed the public archives approach to prominence. Publication of the Library of Congress' rules for cataloging manuscripts (1952) and issuance of the National Union Catalog of Manuscript Collections (1954) encouraged consistent descriptive standards for archival collections. The seminal works of archival theory and practice that appeared shortly after, authored by T.R. Schellenberg (Modern Archives, 1956, and Management of Archives, 1965), Lucille Kane

\footnotetext{
${ }^{12}$ John Fitzpatrick, Notes on the Care, Cataloguing, Calendaring and Arrangement of Manuscripts (Washington: Government Printing Office, 1913).

${ }^{13}$ Luke Gilliland-Swetland, "The Provenance of a Profession: The Permanence of the Public Archives and Historical Manuscripts Traditions in American Archival History," The American Archivist, 54:2 (Spring 1991), 160-175. For a brief history of description, see T. R. Schellenberg, The Management of Archives, (New York: Columbia University Press, 1965), 47-60. More detailed discussions of the conflict of traditions can be found in Frank Evans, "Modern Methods of Arrangement of Archives in the United States," The American Archivist, 29:2 (April 1966), 241-263, and in even greater detail in Berner, Archival Theory and Practice, 24.
} 
("Manuscript Collecting," 1958, and A Guide to the Care and Administration of Manuscripts, 1960), Oliver Wendell Holmes (“Archival Arrangement," 1964), Ernst Posner (American State Archives, 1965), and Frank Evans ("Arrangement of Archives in the United States," 1966) promoted the archival approach over the item-level approach. "The ten years between 1955 and 1965," observed archivist Ann Pederson, "were seminal to the codification of American archival principles and practices." 14

The publications by Schellenberg and Kane, in particular, were critical in shaping archival procedures in the latter twentieth century - and led to the ascendancy of the public archives approach. Schellenberg was the first to synthesize existing theoretical concepts across the museum and library fields - what he called "a compound of the ideas of librarians, historians, and archivists" - into a single, comprehensive text. A historical and theoretical textbook more than a simple operational manual, his 1956 Modern Archives provided one of the first comprehensive descriptions of archival techniques and detailed directions for handling large blocks of government records (Schellenberg spent much of his career working at the National Archives and was able to incorporate practice emerging there in the early 1950s). Its 230 pages integrated earlier archival practice in Europe and other countries with the two traditions of practice in the United States. His subsequent volume, Management of Archives, published in 1965, re-stated his earlier work, but was intended more directly as a textbook describing techniques across all types of records and collections, including those from organizations and corporations, as well as the personal papers of individuals and groups. Both volumes have remained in print since their original publication dates. ${ }^{15}$

\footnotetext{
${ }^{14}$ Quoted section is from Ann Pederson, "Analysis or Prescription? Richard Berner on Archival Theory and Practice," The Midwestern Archivist, 9:1 (1984), 35-43. See also T. R. Schellenberg, Modern Archives: Principles and Techniques (Chicago: University of Chicago Press, 1956); Schellenberg, Management of Archives; Kane, "Manuscript Collecting," Lucille Kane, "A Guide to the Care and Administration of Manuscripts," Bulletin of the American Association for State and Local History, 11:11 (September 1960), 327-388; Oliver Holmes, "Archival Arrangement-Five Different Operations at Five Different Levels," The American Archivist, 27:1 (January 1964), 21-42; Ernst Posner, American State Archives (Chicago: University of Chicago Press, 1964); and Evans, "Modern Methods of Arrangement, 241-63.

${ }^{15}$ Quoted section is from Schellenberg, Management of Archives, 59. See also Hilary Jenkinson, A Manual of Archive Administration (Oxford: The Clarendon Press, 1922); Samuel Muller, J.A. Feith, and Robert Fruin, Manual for the Arrangement and Description of Archives (1898; first U.S. translation: New York:
} 
Kane's Guide to the Care and Administration of Manuscripts was published as a technical monograph by the American Association for State and Local History (AASLH) in 1960 and intended for museum curators given responsibility for archival materials. From her own experience as curator of manuscripts at the Minnesota Historical Society, Kane walked the reader from the basic control processes of an accession register, to organizing, sorting, and describing collections using a card index system. The volume included photographs of techniques being used at the National Archives and included extensive advice on selecting only those few items of most importance, while eliminating others for reasons of bulk, absence of research value, or preservation problems. Although some of her recommendations may seem dated to the modern reader (such as the use of lamination as a preservation technique), Kane communicated key archival values, including the retention of original order. Overall, her volume provided one of the first accessible how-to manuals for smaller organizations attempting to establish and operate an archives. ${ }^{16}$

The popularity of Schellenberg's and Kane's volumes and their use in workshops, institutes, and emerging archival education programs discouraged continuation of the item-level historical manuscripts tradition. Although even as late as 1991 archivists acknowledged that these "two traditions continue to shape professional discourse," practice was clearly trending towards series-level description. ${ }^{17}$

Even though the creators of modern archival practices established consistent methods for organizing and describing manuscripts, they provided few useful guidelines for appraisal and selection. Archival appraisal theory developed initially in the realm of governmental records with Schellenberg's The Appraisal of Modern Public Records, first published as a bulletin of the National Archives in 1956. He advised archivists to understand both the primary value of records (as documentation of the organization that created them) and the secondary evidential and informational values of content to support

H.W. Wilson Company, 1968); Schellenberg, Modern Archives; and Evans, "Modern Methods of Arrangement," 257.

${ }^{16}$ Kane, "Guide to Care of Manuscripts," 327-388.

${ }^{17}$ Quoted section is from Luke Gilliland-Swetland, "The Provenance of a Profession, 172. 
subsequent, external analyses (such as those of historians, educators, and museum curators), but his guidelines were general rather than specific. Archival theorists and practitioners have since suggested a smorgasbord of thoughts on selection, some in line with Schellenberg, and others in opposition. Yet, contrary to such emerging professional appraisal theory - and as the experience of the four repositories in this study will demonstrate - actual appraisal and selection practices more often respond idiosyncratically to local conditions, such as the volume of original materials and the remaining storage space, the format and condition of potential acquisitions, the collecting activities of other agencies (both partners and competitors), and the subject knowledge of the acquisitions personnel. Attempts to codify and standardize selection processes ultimately clash with the highly subjective nature of the work, the unique mission and purposes of the collecting institution, and the critical role staff play in deciding which manuscript items are selected and preserved. ${ }^{18}$

Some scholars feel archival administration suffers from a lack of scholarly research; much of the discipline's published research takes the form of case studies, user surveys, and other reports of practice. Journals are limited, and few have the stature of The American Archivist. Moreover, archivists have had limited success in publishing outside their immediate discipline. Monographic literature has improved in the archival field to some degree, with SAA's Basic Manual series (5 volumes published in 1977) and Archival Fundamentals series (6 volumes published 1990-1993, and revised 2003-2006) helping to achieve "a respectable critical mass." Yet only a limited number of titles explore theoretical concepts. This may be a reflection of the relatively small number of archival practitioners - and smaller number of graduate faculty. ${ }^{19}$

\footnotetext{
${ }^{18}$ Frank Boles, Selecting and Appraising Archives and Manuscripts (Chicago: Society of American Archivists, 2005); and Maygene Daniels, "Records Appraisal and Disposition," in Richard Bradsher, editor, Managing Archives and Archival Institutions (Chicago: University of Chicago Press, 1988), 5366.

${ }^{19}$ Quoted section is from Richard Cox, American Archival Analysis: The Recent Development of the Archival Profession in the United States (Metuchen N.J.: Scarecrow Press, 1990), 22-52. See also Randall Jimerson, "American Archivists and the Search for Professional Identity," in Randall Jimerson, editor, American Archival Studies: Readings in Theory and Practice (Chicago: Society of American Archivists, 2000), 1-23.
} 
For decades various types of single-day, single-course, and two-week 'institutes' provided the only specialized education available to archivists. The early 1970s witnessed the emergence of more intensive multi-course cycles of graduate archival training, most attached to library science, history, or public history programs. Although SAA provided its first set of guidelines for archival education in 1977, no standardization exists across programs, and SAA has never established a system for program accreditation. SAA helped to form the Academy of Certified Archivists (ACA), which created a system for individual certification in 1987, but the concept has received mixed support from practitioners and employers. ${ }^{20}$

Ultimately, the 1960s and 1970s proved a watershed for the maturity and basic stabilization of archival practice. A series of regional archival organizations arose, including the Mid-Atlantic Regional Archives Conference and the Midwest Archives Conference (each founded in 1972), joined by the New England Archivists (1973) and the National Association of Government Archives and Records Administrators (1974). The growth of such membership associations reflected an expansion of archival employment during this period, and graduate-trained archivists became an accepted norm at repositories across the country. By 1980, most universities, colleges, museums, and many larger business enterprises had an established archives department to care for their manuscript holdings, often with an archivist holding some type of graduate training in archival administration. As each repository's reached its mature stage of development, graduate-trained archivists assumed greater control of their manuscript collections. As we will see, this occurred by 1983 in the four repositories of concern here. ${ }^{21}$

\section{A Brief History of the Emergence of Business History and Manuscript Collections in Business, Industry, and Technology}

\footnotetext{
${ }^{20}$ Richard Berner, "Archival Education and Training, 1937 to the Present," in Berner, Archival Theory and Practice, 100-110. Cox, American Archival Analysis, 164-181; Terry Eastwood, "Nurturing Archival Education in the University," The American Archivist, 51:3 (Summer 1988), 228-52; and Jimerson, "American Archivists and the Search for Professional Identity," 8.

${ }^{21}$ Jimerson, "American Archivists and the Search for Professional Identity," 9.
} 
In the 1920s historians began to take greater interest in business and industry, recognizing that they were a core part of the American experience and therefore critical to an understanding of American history. Early business and economic historians like Norman Scott Brien (N.S.B.) Gras, Max Weber, William Ashley, and Arthur Cole, quickly began to develop an interest in primary source materials, particularly the administrative records created by past business enterprises. ${ }^{22}$

The Business History Society, founded at Harvard University in 1925, and the Joint Committee on Materials for Research, established in 1929, made the preservation of business materials a high priority in their initial work. Papers published by Ralph Hower, Oliver Wendell Holmes, and N.S.B. Gras in the 1930s promoting the conservation of business records were distributed to corporations to encourage them to preserve and share their records. Records management practices for the handling of active records within corporations became formalized and professionalized alongside archival techniques. The National Archives established a records management program as early as 1941 which, in turn, encouraged the founding of the Association of Records Executives and Administrators in 1955 and the Association of Records Managers and Administrators (ARMA) in 1956 (the two organizations merged in 1975 under the ARMA name).

Records managers became key players within business enterprises, scheduling the retention and disposal of records in accordance with legal and fiscal requirements, while also remaining attentive to the need for historical information by both the company and external researchers. ${ }^{23}$

${ }^{22}$ Adkins, "Development of Business Archives," 9; and N.S.B. Gras, "Are You Writing Business History?" Bulletin of the Business Historical Society, 18:4 (October 1944), 73-110. A good review of the important role that Harvard's Gay, Donham, Gras, and Cole had in the early development of business history is in Arthur Cole, "The Impact of a Large Collection of Business Literature," Harvard Library Bulletin, 15:2 (April 1967), 180-98. See also T. D. Clark, "Records of Little Businesses as Sources of Social and Economic History," Bulletin of the Business Historical Society, 19:5 (1945), 151-58.

${ }^{23}$ Berner, Archival Theory and Practice, 59, 73; James O'Toole, "The History of the Archives Profession," in James O'Toole, Understanding Archives and Manuscripts, 27-47; Karen Dawley Paul, "Archivists and Records Management," in James Bradsher, editor, Managing Archives and Archival Institutions (Chicago: University of Chicago Press, 1988), 34-52; "History of the ARMA International Educational Foundation," https://www.arma.org/aief/who-we-are/history accessed February 9, 2017; Robert Bailey, "The Certified Records Managers Program," in Irene Place and David Hyslop, editors, Records Management: Controlling Business Information (Reston, Virginia: Reston Publishing Company, 1982), 323-45; Richard Overton, "Can the Records Manager Help the Business Historian?" The Business 
Yet, in early- to mid-twentieth century, few companies saw an economic benefit to building and staffing an internal archives program. Some records, particularly those of defunct companies, made their way into public repositories, but a larger amount remained poorly managed within business enterprises. Several attempts were made to safeguard business records. Shepherd Clough and Thomas Cochran, economic historians at New York University, helped to form the New York Committee on Business Records, which encouraged companies to do the work in-house, or to move historical records to public repositories. Another scheme envisioned gathering the personal papers and business records of influential American business families at a single repository proposed at Columbia University, including the Rockefeller, Carnegie, Ford, Firestone, and Edison papers. $^{24}$

Yet, beyond records management systems, the practice of an active business enterprise preserving records of enduring historical within an internal archives unit is a relatively recent phenomenon. German industrial firms were some of the earliest to create in-house archives, such as the company archives founded at Krupp in Essen in 1905 and

History Review, 29:3 (September 1955), 211-17; James Soltow, "The Business Use of Business History," The Business History Review, 29:3 (September 1955), 227-37; Maynard Brichford, "The Relationship of Records Management Activities to the Field of Business History," The Business History Review, 46:2 (July 1972), 220-32; Oliver Holmes, "Some Reflections on Business Archives in the United States," The American Archivist, 17:4 (October 1954), 295; N. S. B. Gras, "The Value of Research to Business." Bulletin of the Business Historical Society, 3:6 (November 1929), 3-6; Oliver Holmes, "The Evaluation and Preservation of Business Archives." The American Archivist 1: 4 (1938), 171-85; Ralph Hower, "The Preservation of Business Records," Bulletin of the Business Historical Society 11:3/4 (November 1937), 37-61; Herbert Kellar, "Significance and Use of Business Archives," Proceedings of the Society of American Archivists, (1937, no volume number), 34-40; De Forest Mellon, "Preserving Business Records for History, an Issue Raised by the N.R.A." Bulletin of the National Retail Dry Goods Association, 19:3 (June 1934), 18-19, 87-88; David Macmillan, "Business Archives: A Survey of Developments in Great Britain, The United States of America, and in Australia," in Albert Hollaendar, editor, Essays in Memory of Sir Hilary Jenkinson (Chichester, Sussex: Moore and Tillyer, 1962), 110; “About the Business Archives Council,” http://www.businessarchivescouncil.org.uk/about/ aboutintro/ accessed February 8, 2017; Michael Moss and Lesley Richmond, "Business Records: The Prospect from the Global Village," in James O'Toole, editor, The Records of American Business (Chicago: Society of American Archivists, 1997), 369-90; and Adkins, "Development of Business Archives," 9-10.

24 Thomas Cochran, "New York City Business Records: A Plan for Their Preservation," Bulletin of the Business Historical Society, 18:3 (June 1944), 59-62. Arthur Cole critiques the Clough-Cochran proposal in Arthur Cole, "Business Manuscripts: A Pressing Problem," The Journal of Economic History, 5:1 (May 1, 1945) 51-55. See also "Columbia University Library School," October 10, 1950, Box 3, Accession 506, Benson Ford Research Center, The Henry Ford; and Arthur Johnson, "Identification of Business Records for Permanent Preservation," The American Archivist, 24:3 (July 1961), 329-32. 
at Siemens in Berlin in 1907. In the United States, early collections of selected materials were occasionally placed under the control of an in-house library, such as that of the National Safety Council, which established one at the time of its founding in 1913. In other cases, records were preserved in a private family library, such as with the du Pont family papers (one of the case studies of this dissertation). Herbert Kellar organized the records of Cyrus McCormick and International Harvester in 1915, and the Metropolitan Life Insurance Company gathered materials into an "Archives Room" as early as March 1934. By 1943 some archival records were included in company museums at Colt Fire Arms, Scovill Manufacturing, Abbott Laboratories, the Studebaker Corporation, and the American Telephone and Telegraph Company. Staffing for these operations varied in number and training, and many relied on semi-retired employees with deep institutional memory. Although trained librarians were sometimes involved, it was rare for these operations to employ anyone with specialized training to work with manuscripts or organizational records. ${ }^{25}$

The Firestone Tire \& Rubber Company Archives is generally acknowledged as the first professionally-managed corporate archives in the United States. The company established retention and disposal schedules as early as 1929 and invited Ohio State Archivist William Overman to help arrange and describe the materials in 1937-1938. In 1943 Firestone hired Overman permanently, and the archives was formally established. Although the work was partly directed to the company's $50^{\text {th }}$ anniversary in 1950 , Harvey Firestone, Jr., also realized that his company's significant wartime efforts had national historical significance and wanted them properly documented. Firestone was also reportedly of the mind that a company's awareness of its past successes and failures could help to guide its future course. Other corporate archives followed in the 1940s and

${ }^{25}$ Dates for Krupp and Siemens are given in Moss and Richmond, "Business Records: The Prospect from the Global Village," 374. See also Laurence Coleman, Company Museums (Washington, D.C.: The American Association of Museums, 1943); Ruth Parks, "The National Safety Council Archives," Special Libraries, 46:1 (January 1955), 11-13; Kellar, "Significance and Use of Business Archives," 34-40; Margaret Norton, "Herbert Anthony Kellar, 1887-1955." The American Archivist, 19:2 (April 1956), 151-53; Holmes, "Some Reflections on Business Archives," 291-304; Nancy Akers, "Metropolitan Life Insurance Archives," Special Libraries, 46:1 (January 1955), 8-10; and Kane, "Manuscript Collecting," 36. 
1950s, including Alcoa (1949), Lever Brothers (1949), Eastman Kodak (1949), Texaco (1950), Time/Life (1950), and the Ford Motor Company (1950, and a case study in this dissertation). ${ }^{26}$

Interest in corporate archives intensified in the 1970s, influenced by growing public interest in history surrounding the United States' bicentennial in 1976 and growing nostalgia for reproduction products and marketing materials. In addition to the possibility of product sales, many corporations also found easy access to their records useful in the increasing number of lawsuits being brought from government and civil sources.

Historian and former Ford Motor Company archivist Elizabeth Adkins also noted that a growing economy and corporate profits encouraged archival ventures during this period, as well as the "increasingly sophisticated arguments" archivists and historians were making for preserving business records. Archives (and archivists) could have a direct role in the business enterprise - everything from managing trademark and patent information to preparing reports in support of market research, litigation, and product development. ${ }^{27}$

The 1980s posed financial challenges for some corporations - and the demise of their corporate archives or transfer to independent repositories - but the boom-bust economic cycle also saw the creation of many new corporate archives including General Mills (1980), Kraft Foods (1983), Texas Instruments (1984), and Microsoft (1989). ${ }^{28}$

University librarians awoke to the problem of business manuscript materials in the 1930s, and sessions at the annual meetings of the American Library Association were organized by its Committee on Archives and Libraries to describe the challenges at hand.

${ }^{26}$ Adkins notes the challenges in defining what may constitute a "legitimate" company archives. Although several companies identified the need to collect records previous to Firestone, it was the first to employ staff specifically trained in archival recordkeeping practices. See Adkins, "Development of Business Archives," 10-12, 15. See also William Overman, "The Firestone Archives and Library." The American Archivist 16:4 (October 1953), 305-9; Holmes, "Some Reflections on Business Archives," 291-304; and William Overman, "The Pendulum Swings," The American Archivist, 22:1 (January 1959), 3-10.

${ }^{27}$ Quoted section is from Adkins, "Development of Business Archives," 13. See also David Smith, "A Historical Look at Business Archives," The American Archivist, 45:3 (Summer 1982), 276.

${ }^{28}$ Adkins, "Development of Business Archives,"15. For examples of corporate archives developed since 1980, see Karen Benedict, "Collecting Repositories and Corporate Archives: Variations on a Theme?" in O'Toole, editor, The Records of American Business (Chicago: Society of American Archivists, 1997), 349-68; Cynthia Little, "Business History Holdings at the Historical Society of Pennsylvania," The Business History Review, 70:1 (Spring 1996), 91-107; and Deidre Simmons, Keepers of the Record: The History of the Hudson's Bay Company Archives (Montreal: McGill-Queen's University Press, 2007). 
Universities began to collect business records, providing an alternative for businesses interested in preserving their records. The Baker Library at Harvard University (a case study in this dissertation) was the first significant academic collector, starting with its acquisition of textile records from the Slater Company in 1916. Other early academic collectors included the Pennsylvania Historical Society, the University of Michigan, and the University of Illinois, though many more universities and colleges began to take an active interest in business records in the 1950s. Because of the enormous bulk of records created by companies and limited staff to process records, some simply limited their acquisitions to smaller collections of business materials created before $1890 .^{29}$

Museums, like academic libraries, increased their collections of business records in the twentieth century, influenced by a variety of factors. Industrial history had long been a popular topic for museums. During the industrial revolution many organizations developed technology-oriented collections, such as the Franklin Institute founded in Philadelphia in 1824. The international expositions which began around 1850 celebrated the innovations and new products of industrialization, but they also helped build the collections of several important museums. Materials from the Great Exhibition at London's Crystal Palace in 1851 were acquired to develop Britain's South Kensington Museum in 1852 (now known as The Science Museum), the United States' 1876 Centennial Exposition fed important technological collections to the fledgling Smithsonian Institution, while materials gathered for the 1893 World's Columbian Exposition formed the basis for Chicago's Field Museum and supplied the location for the Museum of Science and Industry (which also incorporated materials from Chicago's 1933 Century of Progress Exposition). Some industrial museums were closely associated with business and industrial entrepreneurs, such as German engineer Oskar von Miller's development of Munich's Deutsches Museum and Henry Ford's sponsorship of a museum in Dearborn, Michigan. Additionally, many active corporations created publiclyaccessible historical exhibits and interpretive experiences, such as the World of Coca-

\footnotetext{
${ }^{29}$ Cole, "Business Manuscripts: A Pressing Problem," 46, 52; Kane, "Guide to the Care of Manuscripts," 358; Holmes, "Some Reflections on Business Archives," 298-99; Adkins, "Development of Business Archives," 13.
} 
Cola in Atlanta, Georgia, and the dozen museum facilities Wells Fargo operates from Alaska to San Francisco to Philadelphia. ${ }^{30}$

Museums, however, tended to highlight business and industry primarily through the use of graphical content in exhibits, such as advertising materials, photographs, drawings, and artifacts. Manuscripts were often only a small part of their collections and usually played a secondary role to three dimensional artifacts. As several case studies in this study will reveal, aspects of an individual museum's funding, mission, and purpose greatly influenced the specific types of manuscript items collected and preserved. ${ }^{31}$

Whether within a corporation, in an academic library, or in a museum, records of business, industry, and technology posed significant new problems for archives and archivists. The primary problem was volume. By the late nineteenth century, new duplication technologies, cost accounting systems, and other forms of corporate administrative reporting had resulted in an explosion of records within business and

${ }^{30}$ Bedini, "The Evolution of Science Museums," 1-29; Stella Butler, Science and Technology Museums (Leicester: Leicester University Press, 1992); and Eugene Ferguson, "Technical Museums and International Exhibitions," Technology and Culture, 6:1 (Winter 1965), 30-46.

${ }^{31}$ For insight into the difficulty in working with corporate sponsors, see Michal McMahon, "The Romance of Technological Progress: A Critical Review of the National Air and Space Museum." Technology and Culture, 22:2 (April 1981), 281-96. See also John Fleckner, "Reaching the Mass Audience: Business History as Popular History," in O'Toole, editor, The Records of American Business (Chicago: Society of American Archivists, 1997), 327-48; and Linda Endersby, Expositions, Museums, and Technological Display: Building Cultural Institutions for the "inventor Citizen" in the Late Nineteenth Century United States (PhD Dissertation, Massachusetts Institute of Technology, 1999); Susan Smulyan, "America's Smithsonian." The Public Historian, 19: 3 (July 1997), 87-91; John White, "The Railway Museum: Past, Present, and Future." Technology and Culture, 14: 4 (October 1973), 599-613; and Steven Lubar, "The Computer Museum, Boston, Massachusetts," Technology and Culture 27:1 (January 1986), 96-105. The literature on exhibiting the history of technology is extensive and includes Brooke Hindle, "Museum Treatment of Industrialization: History, Problems, Opportunities," Curator, 15:3 (1972), 206-13; Carroll Pursell, "The History of Technology and the Study of Material Culture," American Quarterly, 35:3 (January 1983), 304-15; Thomas Leavitt, "Toward a Standard of Excellence: The Nature and Purpose of Exhibit Reviews," Technology and Culture, 9:1 (January 1968), 70-75; Merritt Roe Smith, "Toward a Standard of Excellence: The Second Installment," Technology and Culture, 15:1 (January 1974), 76-79; Bernard Finn, "Exhibit Reviews-Twenty Years After," Technology and Culture, 30:4 (October 1989), 993-1003; Brooke Hindle, "Comment: Museum Reviews and the History of Technology," in Donald Hoke, editor, The History and Sociology of Technology: Proceedings of the Twenty-fourth Annual Meeting of the Society for the History of Technology, Milwaukee, Wisconsin, October 14-17, 1981 (Milwaukee: The Society for the History of Technology, 1982), 200-201; George Basalla, "Museums and Technological Utopianism," in Ian Quimby and Polly Anne Earl, editors, Technological Innovation and the Decorative Arts: Winterthur Conference Report 1973 (Charlottesville, Va., 1974), 355-73, and reprinted in Curator, 17:2 (1974), 105-118. 
industrial firms. William Overton, a research consultant for the Bureau of Railway Economics, referred to it in 1955 as the "Battle of the Bulk," with companies producing millions of documents each year. Some repositories limited their acquisitions to the more manageable records of smaller pre-1890 business ventures, collections which also allowed 1ibrarians to apply familiar, item-level description. But systems of calendaring and cataloging used in the historical manuscripts tradition proved increasingly untenable in the face of bulky collections produced in the twentieth century, as seen at the four repositories in this study. Repositories interested in business materials eventually adopted, of necessity, descriptive systems in line with the emerging public records approach. Bifurcated systems at institutions holding both personal papers (often amenable to the item-level approach) and business records of various vintage (far less amenable) often led to clashes between staff. The overwhelming volume of business and industrial collections also caused tensions between those staff focused on acquisitions and others responsible for the arrangement and description of those collections. Yet another problem with business records was the issue of availability: some business enterprises were willing to donate older, inactive records to public repositories, but others were unwilling to allow public access to their materials, either securing them internally or simply discarding them altogether. ${ }^{32}$

Ironically, with such potentially rich and extensive resources, scholars continue to complain of a lack of accessible resources for the study of business, industrial and technological history. Francis Blouin notes that in comparison to political, education, and religious topics, business and industrial historians have "very little documentation with which to work." Florence Bartoshesky, a manuscripts archivist at Baker Library in the Harvard University Graduate School of Business Administration, described the problem in 1985:

\footnotetext{
32 "Battle of the Bulk" is quoted from Overton, "Can the Records Manager Help the Business Historian?" 212. See also Francis Blouin, "A New Perspective on the Appraisal of Business Records: A Review," The American Archivist, 42:3 (July 1979), 317; JoAnne Yates, Control through Communication: The Rise of System in American Management (Baltimore: Johns Hopkins University Press, 1989); "Early Writing," Harry Ransom Center, University of Texas at Austin, http://www.hrc.utexas.edu/educator/ modules/gutenberg/books/early/ accessed February 16, 2017.
} 
The volume of [corporate] records created annually is vast and increasing. Yet because of economic constraints, repositories can hope to collect only a small fraction of the total volume of records that survive. So archivists and other interested parties must make decisions about which records will be saved and which will perish. ${ }^{33}$

This conundrum between the massive documentation produced by business and industrial enterprises - and the limited material archives are able to preserve - raises many questions about the ways in which archivists, librarians, and museum curators have made critical selection decisions affecting the permanent archival record. ${ }^{34}$

Acquisition decisions have also been affected by the interplay between the research interests of historians and the work of librarians and archivists at these repositories. Initial approaches to the scholarly study of business, such as those promoted at Harvard by N.S.B. Gras, centered on individual firms and, in turn, encouraged archivists to focus on collecting annual reports, minutes of corporate boards, and the general accounting records of specific firms. This direction was supported by publications in the Harvard Studies in Business History series, begun in 1931, which examined notable early business figures, such as John Jacob Astor and Jay Cooke, and medium-sized business institutions, such as the Massachusetts First National Bank and the advertising firm Ayer \& Son. ${ }^{35}$

Later historians eschewed this top down approach, feeling that business was a part of the larger society it served. Under Arthur Cole's leadership, authors like Thomas Cochran and Alfred Chandler took a more generalized and interdisciplinary approach to entrepreneurial history, drawing from a much broader variety of primary and secondary sources. At an enterprise level, these studies examined larger, vertically-integrated companies, including railroads, automobile manufacturers, and chemical companies.

${ }^{33}$ Florence Bartoshesky, "Business Records at the Harvard Business School." The Business History Review, 59:3 (Autumn 1985), 475.

${ }^{34}$ Quoted section is from Francis Blouin, "Business and American Culture: The Archival Challenge," in O'Toole, editor, The Records of American Business (Chicago: Society of American Archivists, 1997), 1.

${ }^{35}$ N.S.B. Gras, "What Is Business History," Bulletin of the Business Historical Society, 18:4 (October 1944), 87-91; Cole, "The Impact of a Large Collection," 185; Michael Nash, "Business History and Archival Practice," in J O'Toole, editor, The Records of American Business, (Chicago: Society of American Archivists, 1997), 15. 
"The complexity of the organizational structure," noted archivist Francis Blouin, "led to a complexity in the kinds of records required." More recent business history scholarship has moved away from large-scale enterprises to other forms of business organization, including formal and informal networks, making collecting decisions even more difficult. $^{36}$

Exacerbating the difficulties of collecting further, specialized interest in the history of technology developed within the larger business history agenda, emphasizing the increasing role of technology in business practice and social history. Following publication of the encyclopedic five-volume History of Technology, edited by Charles Singer, the Society for the History of Technology was founded in 1958 and began publication of its journal, Technology and Culture, in the following year. Shortly after, heightened interest in the study of industrial remains led to the founding of the Society for Industrial Archeology in 1971. Historians of technology, such as Thomas Hughes, Reese Jenkins, and David Hounshell, soon sought records of laboratories, engineers, and manufacturing plants - records previously ignored - as yet another lens to examine business history. ${ }^{37}$

${ }^{36}$ Quoted section is from Francis Blouin, "A New Perspective, 318. Michael Nash provides a useful analysis of the changes in the use of primary source material in "Business History and Archival Practice," 11-40. Nash's citation analysis calculated that Thomas Cochran reviewed more than 100,000 letters for his Railroad Leaders, 1845-1890: The Business Mind in Action (Cambridge: Harvard University Press, 1953). While citations weighed more toward secondary sources in Alfred Chandler's Strategy and Structure (Cambridge: MIT Press, 1962) and The Visible Hand: The Managerial Revolution in American Business (Cambridge: Belknap Press, 1977), Nash noted the growing importance of primary sources to researchers in the history of technology. The work of JoAnne Yates examines office technologies and their use in controlling the workforce. See JoAnne Yates, "Internal Communication Systems in American Business Structures: A Framework to Aid Appraisal," The American Archivist, 48:2 (Spring 1985), 141-58, and Yates, Control through Communication. The Records of American Business (Chicago: Society of American Archivists, 1997) includes chapters promoting functional analysis, sampling, and an elaborate "Minnesota Method" developed by the Minnesota Historical Society to more comprehensively collect business records in that state. See also Arthur Cole, "The Committee on Research in Economic History: An Historical Sketch." The Journal of Economic History, 30:4 (December 1970), 723-41; Richard Wohl, "The Significance of Business History," The Business History Review, 28:2 (June 1954), 128-40; Cole, "Impact of a Large Collection," 190-97; Blouin, "Business and American Culture,", 1-9; and Blouin, "A New Perspective," 312-20,

${ }^{37}$ Melvin Kranzberg, "At the Start." Technology and Culture 1:1 (Winter 1959), 1-10; Charles Singer, et al., editors, A History of Technology, 5 vols. (Oxford: Clarendon Press, 1954). 


\section{Literature Review}

There is no existing literature which compares and contrasts the founding and early manuscript collecting activity of multiple repositories specializing in the records of business, industry, and technology. Existing literature examining the activity of business archives includes broad sources on the rise of scholarly interest in business history, published histories of specific archives, and material published by archivists working with such records. This varied material can be classified in a number of categories, including (1) descriptions of particular collections; (2) general "how to" guides; (3) specialized "how to" guides; (4) discussions of standardizing archival practices for these specialized records; (5) directories of business archives; and (6) bibliographical compilations. We will look at each of these categories in turn.

Descriptions of particular collections at particular times can be useful for tracing the evolution of these collections, especially when multiple descriptions have been published over time. Moreover, while largely descriptive of a collection at a particular time, some of these descriptions do contain some historical material. Examples of this literature include William Overman's 1953 description of the Firestone archives; Nancy Akers' 1955 report on the Metropolitan Life Insurance Archives; and T. A. Boyd's review of the Charles Kettering Archives in 1964. As this study will show, similar descriptions were provided through the published reports of directors, archivists, librarians, and curators at our four case study institutions. ${ }^{38}$

As corporate and public collections of business records expanded, a literature emerged that attempted to advise and instruct repositories on what to keep and how to arrange and preserve these materials, that is, general "how to" guides. Arthur Cole, who had become head librarian at the Baker Library at Harvard University, published one of the first such guides for business archives in January 1938. His article, "Business Manuscripts: Collection, Handling, Cataloging," published initially in Library Quarterly,

\footnotetext{
${ }^{38}$ William Overman, "The Firestone Archives and Library," 305-9; Akers, "Metropolitan Life Archives," 8-10; and T. A. Boyd, "The Charles F. Kettering Archives," Technology and Culture, 5:3 (Summer 1964), 412-15.
} 
provided a short overview of Baker Library's growing business history collection and presented a detailed description of how his staff were arranging, describing, and physically handling these materials. That same year, Herbert Kellar discussed his work on the McCormick papers, describing his methods of arrangement and description and noting that they were "susceptible of adoption for other business records." Cole's and Kellar's works were expanded in a special issue of the journal Public Documents with Archives and Libraries issued by the American Library Association in 1938 - along with another ten articles on the preservation and organization of manuscript material. Cole continued to write about issues relating to the preservation, description, and use of business records throughout his life. Ralph Hower's extended 1937 article, "The Preservation of Business Records," included sections on which records should be selected and how they should be handled. The article was reprinted by the Business Historical Society as a separate volume and had significant influence on the topic across business, library, and archival sectors. ${ }^{39}$

As the number of corporate archives increased in the post-war period, so too did the number of articles written by corporate archivists describing how they did their work. William Overman's 1953 review of the Firestone archives detailed cataloging of photographs and records using a card index, use of microfilming for engineering drawings and other records to reduce space, and his department's management of a large company book library. Nancy Akers' 1955 report from the Metropolitan Life Insurance Archives described their accessioning system and installations in the company's "exhibit area." Other writers supplied specialized instructions on the use of microfilming, oral

\footnotetext{
${ }^{39}$ Quoted section is Kellar, "Significance and Use of Business Archives," 36. See also Cole, "Business Manuscripts: A Pressing Problem," 46; Arthur Cole, "Business Manuscripts: Collection, Handling, Cataloging," Library Quarterly 8:1 (January 1938), 93-114; Arthur Cole, "Principles for the Selection of Materials for Preservation in Collections of Business Records," Public Documents with Archives and Libraries, 6 (1938), 349-56; Herbert Kellar, "Organization and Preservation of Manuscript Collections in the McCormick Historical Association Library," Public Documents with Archives and Libraries, 6 (1938), 357-64; Arthur Cole, "Organization and Preservation of Manuscript Collections in the Baker Library of the Harvard Business School," Public Documents with Archives and Libraries, 6 (1938), 380 86; Cole, "Business Manuscripts: A Pressing Problem," 43-59; Cole, "Impact of a Large Collection," 180-98; Arthur Cole, The Birth of a New Social Science Discipline: Achievements of the First Generation of American Economic and Business Historians, 1893-1974 (New York: Economic History Association, 1974); Ralph Hower, "The Preservation of Business Records," 37-61.
} 
history, and other techniques to reduce the bulk of company collections and fill gaps in the written record. ${ }^{40}$

As practice expanded with records of business, industry, and technology, specialized "how to" guides described emerging practice for particular sectors. For example, an article by De Forest Mellon, published in 1934 in The Bulletin of the National Retail Dry Goods Association described a project with T.R. Schellenberg to identify, sample, and preserve representative records from retail stores. While hardly a source that archivists might be expected to have close at hand, their recommendations ("neither laborious nor costly") were directed to merchants working in the commercial retail trade and those responsible for their archival records. A May 1954 symposium on "Handling Company Archives and Company Historical Material" was sponsored by the Insurance Division of the Special Libraries Association in Cincinnati, Ohio. By 1978, SAA's Business Archives Section published its own "how to" guide, Business Archives: An Introduction. Although only 28 pages long, the volume was directed to companies seeking to establish an internal archives programs and provided sections on appraisal, arrangement and description, conservation, and oral history, and also provided useful recommendations for staffing, space, and operating budget. ${ }^{41}$

${ }^{40}$ Overman, "The Firestone Archives and Library." 308-9; Nancy Akers, "Metropolitan Life Insurance Archives," 8-10; Irving Zitmore, "How to Decide Whether to Microfilm Business Records and How to Go About It," Journal of Accountancy, 40:2 (February 1951), 276-281; Owen Bombard, “A New Measure of Things Past," The American Archivist, 18: 2 (1955), 123-32; Boyd, "The Charles F. Kettering Archives," 412-15; Gary Saretzky, "Oral History in American Business Archives," The American Archivist, 44:4 (Fall 1981), 353-55.

${ }^{41}$ De Forest Mellon, "Preserving Business Records for History, an Issue Raised by the N.R.A.,"18-19, 8788. National Fire Protection Association and Committee on Protection of Records, Protection of Records: Consolidated Reports of the Committee on Protection of Records. (Boston, Massachusetts: National Fire Protection Association, 1935); Hower, "The Preservation of Business Records," 37-61; Holmes, "Some Reflections on Business Archives in the United States," 295; "Symposium: Company Archives," Special Libraries, 46:1 (January 1955), 7; Emma McCall, "Notes on Handling and Preserving Company Historical Materials," Special Libraries 46, no. 1 (January 1955), 16-17; Vernie Wolfsberg, "Building Company Archives," Special Libraries 46, no. 1 (January 1955), 13-15; Edie Hedlin, Business Archives: An Introduction, (Chicago: Society of American Archivists, 1978); Courtney Bailey, "Identify In Flux: The Evolution of the Selection and Retention of Business Records," April 24, 2012, 7, https://cbaileymsls.files.wordpress.com/2015/04/755_business-records.pdf accessed February 1, 2017; Society of American Archivists, "Business Archives: Establishing and Managing an Archives," http://www2.archivists.org/prof-education/course-catalog/business-archives-\%E2\%80\%A6-establishingand-managing-an-archives accessed September 2, 2017. 
Another area of specialization concerned appraisal and selection. Archivist and business historian Elizabeth Adkins, reflecting on Schellenberg's work, noted ongoing conflicts between the primary, informational, value of specific business records internally to their parent enterprises, and the secondary values which lead historians and other external audiences to demand access. Francis Blouin further acknowledged the challenges in appraising materials from twentieth century firms, particularly the lack of guidelines or requirements for corporations - and business' seeming disinterest in doing anything about these mounting problems. More recently, the "Records of American Business" project, initiated in 1993 by James Fogerty at the Minnesota Historical Society, took a hard look at collecting, processing, and research using business records. The work resulted in a symposium (sponsored by MHS and the Hagley Museum and Library) and an edited volume of essays published by the Society of American Archivists in 1997. Other writers have observed a pragmatic shift in more recent years within corporate archives from broadly preserving records documenting the heritage and contributions of their company, to preserving only those few items fulfilling legal or fiscal regulations. While some government regulations require certain documents to be retained by companies, they also indirectly encourage corporations to actively destroy materials (following legally-acceptable disposal schedules) so they cannot be demanded during discovery in subsequent litigation. Although there have been success stories, these issues and the burdens of regulatory reporting and litigation continue to discourage companies from protecting and sharing historical records - and place tremendous pressure on underresourced non-corporate repositories to cull from voluminous sets of business records all but the most high use materials required by their patrons. ${ }^{42}$

As the archival community solidified its position and recognized the problems associated with collecting business, industrial, and technological records, some practitioners shifted from "how to" descriptions to discussions about formalizing

${ }^{42}$ O'Toole, editor, The Records of American Business (Chicago: Society of American Archivists, 1997). See Adkins' commentary about the RAB project in "Development of Business Archives," 16; See also Francis Blouin, "An Agenda for the Appraisal of Business Records" in Nancy Peace, editor, Archival Choices: Managing the Historical Record in an Age of Abundance (Lexington, Massachusetts: Lexington Books, 1984). 61-79. 
techniques and establishing standards for handling business records. For instance, the National Records Management Council, founded in 1949, published the first guide for federal records retention in 1950 and continued to issue guides and manuals for business records later that decade. The intent was to standardize practices for bureaucratic records. The Controllership Foundation compiled a series of case studies in 1957, which it intended to serve as models for a standardized approach to records management. It detailing actual records practice at a dozen different companies, including copies of records transfer forms, photographs of storage facilities, and detailed accounts of reference activity. The British Business Archives Council issued its first typescript guide for "listing, indexing, and reporting on business archives" in November 1959. 43

By the early 1980s business/industrial archives were firmly established in the United States and were increasingly directed by professional archivists. This growing maturity was reflected in the compilation and publication of directories of business archives and archivists. The Business Archives Section of SAA compiled its first directory, Business Archives in the United States and Canada, in 1975. The group also conducted the first of a series of surveys of businesses and business archivists in 1975, which helped to raise awareness of the need to preserve and share such records. Similar directories were periodically published by the British Business Archives Council before its first full directory in 1985, as well as a massive survey in 1986 reporting the locations of records from 1,000 of the earliest registered companies in England and Wales. ${ }^{44}$

\footnotetext{
${ }^{43}$ Arthur Barcan, "Records Management and the 'Paperwork Age,"” The Business History Review, 29:3 (September 1955), 218-26; National Records Management Council, Index to Federal Record Keeping Requirements (New York: National Records Management Council, 1955); Holmes, "Some Reflections on Business Archives in the United States," 295-6; Jewel Moberley, Case Studies in Records Retention and Control (New York: Controllership Foundation, 1957); Business Archives Council, Guide to Methods of Listing, Indexing and Reporting on Business Archives (London: The Council, 1959); James Barrett, "Acquisition in Industrial Archives," The American Archivist, 24:3 (July 1961), 333-36; and F. L. Sward, "Business Records Management," The American Archivist, 29:1 (January 1966), 69-74. ${ }^{44}$ Society of American Archivists, Directory of Business Archives in the United States and Canada (Chicago: The Society, 1975); the current directory is part of the SAA website at http://www2.archivists.org/groups/business-archives-section/directory-of-corporate-archives-in-theunited-states-and-canada-introduction accessed February 8, 2017. See also Gary Saretzky, "North American Business Archives: Results of a Survey," The American Archivist 40:4 (October 1977), 41319; John Armstrong, Directory of Corporate Archives: Some Corporate Members of the Business Archives Council Which Maintain Archive Facilities (London: Business Archives Council, 1985); Lesley Richmond and Alison Turton, Directory of Corporate Archives: A Guide to British Businesses Which
} 
Finally, the growth of literature relating to business/industrial/technological archives eventually encouraged compilation of bibliographies. Henrietta Larson's Guide to Business History, published in 1948, the first comprehensive bibliography to the discipline with more than 5,000 references, included a section on archives. David Gilchrist, an archivist for industrial collections at the Hagley Library and Museum, developed a bibliography which he shared freely in the early 1960s. It listed key works on the problems associated with collecting business manuscripts, including the early work of Arthur Cole and Robert Lovett at the Baker Library, materials about business manuscript collections at the Newberry Library in Chicago, and work being done to preserve and organize records of the Firestone Company and Ford Motor Company. Eugene Ferguson's Bibliography of the History of Technology, published in 1968, like Larson's guide to business history, included a section devoted to archival resources. In 1981, the Society of American Archivists compiled its Select Bibliography on Business Archives and Records Management. Its nearly 500 entries comprehensively documented the early development and literature of these sectors. ${ }^{45}$

Previously published literature provides glimpses into the issues which affect the collection of business and industrial records. Yet no previous author has attempted a book-length historical and comparative study of multiple repositories collecting in this thematic area. This dissertation does this.

Maintain Archive Facilities (London: Business Archives Council, 1997); and Lesley Richmond and Bridget Stockford, Company Archives: A Survey of the Records of 1000 of the First Registered Companies in England and Wales (Aldershot, England: Gower, 1986).

${ }^{45}$ Henrietta Larson, Guide to Business History: Materials for the Study of American Business History and Suggestions for Their Use (Boston: J. S. Canner, 1948). Gilchrist's bibliography is referenced in a memoranda, David Gilchrist to Richmond Williams, "Report of the Activities of the Specialist for the Period July 9, 1962 to December 31, 1962," 3, Box 169, Folder “Annual Reports-Library, 1960-1967," Record Group 5, Eleutherian Mills Hagley Foundation Archives, Hagley Library and Museum. See also Eugene Ferguson, Bibliography on the History of Technology (Cambridge, Massachusetts: Massachusetts Institute of Technology, 1968); and Karen Benedict, A Select Bibliography on Business Archives and Records Management (Chicago, IL: Society of American Archivists, 1981). 


\section{Scope of this Study}

This dissertation compares and contrasts the founding of and early manuscript collecting at the Baker Library at Harvard University in Boston, Massachusetts; the Hagley Library and Museum in Wilmington, Delaware; the Archives Center at the National Museum of American History in Washington, D.C.; and the Benson Ford Research Center at the Henry Ford museum in Dearborn, Michigan.

There is no standardized terminology for archival records specifically from the realm of business, industry, and the history of technology. Herbert Kellar, archivist for the McCormick Reaper Company records, and one of the earliest to write on the importance of business archives, defined these types of primary resources "as records of private and semi-public economic enterprises, owned and controlled by individuals, companies, or corporations, which are organized and operated with the intent of profit." Agreeing with archival leader Lester Cappon that the lines between archives, records, personal papers, and manuscript collections "cannot be easily or sensibly drawn" - and hoping to keep such definitions from distracting from the main narrative of this dissertation - this author employs a less formal approach where the terms archives, papers, records, and manuscripts are used interchangeably. ${ }^{46}$

\section{Selection of Case Study Repositories}

Table 1.1 provides an overview of the four case study repositories, with some introductory comparative information. Given the large number of institutions collecting

\footnotetext{
${ }^{46}$ Archives, by the strictest definition, are the body of records created by a single entity, such those of an active corporation, though some repositories may call that same body of records a manuscript collection once it has been donated by a company to a university or nonprofit repository. The administrative files of an archival repository, such as those documenting the internal operations of the four case study institutions, may also be considered the archives of the repository which holds them, whereas the personal papers of a deceased engineer collected at the repository would be considered a manuscript collection. Many archival historians apply the phrase personal papers to manuscripts relating to an individual, while records relate to organizations, both non- and for-profit. Kellar's quote is from Kellar, "Significance and Use of Business Archives," 34. Cappon's quote is from Lester Cappon, "Historical Manuscripts as Archives: Some Definitions and Their Application," The American Archivist, 19:2 (April 1956), 105. See also Robert Lovett, "Of Manuscripts and Archives," Special Libraries, 64 (October 1973), 415-18; and Berner, Archival Theory and Practice, 48.
} 
industrial materials, it is impossible to systematically study appraisal and selection practices historically across the entire nation. Limitations of time and space required this study to focus on only four repositories. The selection of these four specific institutions, however, was made with the deliberate intention of highlighting the many challenges attending collecting records of business, industry, and technology across a variety of contexts.

It is clear that similar materials are preserved in many public repositories across the country. Representative samples of local business records are routinely collected by small history museums and public libraries, and some universities support regional manuscript collections including larger corporate collections. Records of both defunct and active businesses have made their way into hundreds of these types of repositories historian Arthur Cole referenced more than 140 libraries and historical societies holding business records in $1945 .{ }^{47}$

While many small repositories have captured portions of specific local enterprises, a few hold significant large single industrial collections, such as the 10,000 linear feet of records from the Homestake Mining Company held by the Homestake Adams Research and Cultural Center in Deadwood, South Dakota. Some larger regional history centers, state archives, and larger university archives are funded sufficiently to collect materials relating to a prominent, major regional industry or theme. In these cases, business records are held alongside religious, municipal, fraternal, and personal manuscripts. Examples of these collections are those focused on copper mining on Michigan's Keweenaw Peninsula (at the Michigan Technological University Archives and Copper Country Historical Collections), on fisheries (at the Center for Pacific Northwest Studies at Western Washington University), and on the cattle industry (at the Cattle Trails of the West collections at the Colorado Historical Society). Finally, this study could also have looked at numerous larger repositories actively collecting business records with a regional or industrial focus, such as the collections of Southern business records at University of Kentucky and Duke University, railroads at the Newberry

${ }^{47}$ Cole, "Business Manuscripts: A Pressing Problem," 43-59. 
Table 1.1 - Overview of Case Study Repositories ${ }^{48}$

\begin{tabular}{|c|c|}
\hline \multicolumn{2}{|c|}{ Baker Library, Harvard Graduate School of Business, Cambridge, Massachusetts } \\
\hline Date Established & 1908 \\
\hline Period of rapid growth & 1927-1956 \\
\hline Purpose & $\begin{array}{l}\text { Support university graduate student and faculty research, particularly the } \\
\text { "business case study" model established at Harvard }\end{array}$ \\
\hline Models & No established models \\
\hline Partners / Networks & Harvard alumni, the Business History Society \\
\hline Pre-1983 Staffing & Initially business and economic historians \\
\hline Growth of Collections & $\begin{array}{l}1932=508 \text { collections } \\
1951=1,067 \text { collections } \\
1978=1,403 \text { collections }\end{array}$ \\
\hline \multicolumn{2}{|r|}{ Hagley Museum and Library, Wilmington, Delaware } \\
\hline Date Established & 1952 Museum, 1953 Library, 1961 Merger \\
\hline Period of rapid growth & DuPont collections 1955-1961, regional collections 1961-1982 \\
\hline Purpose & $\begin{array}{l}\text { Public research collection. Initially to preserve person papers of du Pont family } \\
\text { and records of the DuPont Company; expanded to document industry in the } \\
\text { Delaware Valley. }\end{array}$ \\
\hline Models & Folger Library, Huntington Library, Industrial site museums \\
\hline Partners / Networks & du Pont family support, professional societies \\
\hline Pre-1983 Staffing & Initially librarians \\
\hline Growth of Collections & $\begin{array}{l}1955=\text { fewer than } 12 \text { collections } / 200,000 \text { items } \\
1961=316 \text { collections } / 1,000,000 \text { items } \\
1978=1,525 \text { collections } / 6,000,000 \text { items } \\
1982=1,803 \text { collections }\end{array}$ \\
\hline \multicolumn{2}{|c|}{ National Museum of American History, Smithsonian Institution, Washington, D.C. } \\
\hline Date Established & 1954 \\
\hline Period of rapid growth & 1954-1964, though continuing with industrial materials through 1983 \\
\hline Purpose & Support museum exhibitions and curators' research \\
\hline Models & European national industrial museums \\
\hline Partners / Networks & $\begin{array}{l}\text { Industrial corporations, engineering departments in universities and technical } \\
\text { colleges, emerging associations of industrial historians }\end{array}$ \\
\hline Pre-1983 Staffing & Engineers, scientists, and people from industry; industrial historians \\
\hline Growth of Collections & $\begin{array}{l}1966=3,325 \text { cubic feet } \\
1986=4,500 \text { cubic feet }\end{array}$ \\
\hline \multicolumn{2}{|c|}{ Benson Ford Research Center, The Henry Ford, Dearborn, Michigan } \\
\hline Date Established & 1929 Ford Museum, 1950 Ford Motor Company Archives, 1964 Merged \\
\hline Period of rapid growth & 1950-1954 \\
\hline Purpose & $\begin{array}{l}\text { Some manuscripts as part of the museum development, but larger part of the } \\
\text { current collection developed as an internal Ford Motor Company archive } \\
\text { developed to support its } 50^{\text {th }} \text { anniversary }\end{array}$ \\
\hline Models & Industrial museums, open air museums, corporate archives \\
\hline Partners / Networks & Henry Ford, Ford Motor Company, car enthusiasts \\
\hline Pre-1983 Staffing & Librarians, archivists, marketing and public relations staff \\
\hline Growth of Collections & $\begin{array}{l}1951=2,543 \text { cubic feet in Ford Motor Company Archives } \\
1956=10,270 \text { cubic feet in Ford Motor Company Archives } \\
1964=8,000 \text { cubic feet donated to Ford Museum } \\
1980=10,000 \text { cubic feet at Ford Museum }\end{array}$ \\
\hline
\end{tabular}

${ }^{48}$ Data is drawn from various sources detailed in the case study chapters which follow. 
Library in Chicago, marine records at Mystic Seaport, or the extensive business holdings of the Minnesota Historical Society.

Baker Library, Hagley, and Smithsonian were selected for this study due to the national reputation of their broad collections of nineteenth and twentieth century American business and industrial concerns. These institutions hold thousands of cubic feet of diverse material relating to mining companies, engine manufacturers, railroad locomotive works, and other industrial enterprises and are well known to business historians and to scholars researching the history of business, industry, and technology.

The fourth case study, examining business and industrial manuscripts held at The Henry Ford, was selected to juxtapose a smaller, more focused repository and explore how its evolution varied from the other, broader, collectors. The development of manuscript collections relating to Henry Ford and the Ford Motor Company, for example, provides a useful contrast to the Hagley Library and Museum - the connection to a large corporation, a noted industrialist, and an industrial site - and there is a useable core of administrative records publicly accessible at the Benson Ford Research Center to support many aspects of this study. In addition, the Ford case reveals important relationships between non-corporate repositories and their corporate donors, as well as competing priorities for continuing use of records, corporate secrecy, and public access and research use.

Several other repositories were considered for the fourth case. For instance, the Michigan Technological University Archives and Copper Country Historical Collections in Houghton, Michigan, originated in the 1970s to preserve historical materials relating to Michigan's historic copper mining industry. Unfortunately, that repository did not operate collection committees, record formal selection processes, or create minutes of meetings or other documents that might reveal its approach to appraisal/selection - gaps in the historical record which were unlikely to be filled by oral interviews or published sources. The Bessemer Historical Society in Pueblo, Colorado, manages the records of the Colorado Fuel and Iron Company, a large mining, railroad, and manufacturing company working across several Western states. While possibly providing useful contrast to eastern examples - particularly those operating at historical industrial sites - its recent 
founding in 2003 did not fit the chronological limits set for this study (discussed below), it has not yet accomplished control of its archival holdings, and there is little actual practice yet to critique. ${ }^{49}$

\section{Structure and Temporal Limits}

This dissertation consists of six chapters: an introduction/literature review, four case studies, and a concluding chapter providing additional commentary and analysis. The order of the case study chapters is not strictly chronological. The study begins with Baker Library, the repository with the earliest founding date and broadest collections, and ends with The Henry Ford, the repository with the narrowest scope. The primary focus is on the establishment and initial periods of rapid growth of their manuscript collections, as each sought to create and stabilize its manuscript acquisition policies and priorities.

The study follows the four repositories only to 1983, when business history and the administration of business archives had reached a level of maturity and each case study institution turned to professionally trained archivists to manage its collections. By that time such personnel were readily available, for as this introduction and literature review has revealed, by the early 1980s archivists, librarians, and museum curators had created systems for graduate education and accreditation, had established membership organizations, and supported conferences, journals, and monographs to share practice and discuss theoretical issues. This transition period during the early 1980s also witnessed significant staffing changes including the retirement of key figures involved in their early manuscript collecting.

Moreover, by 1983, all four repositories had established their core collections of business and industrial records. Although each has added to their collections since that date - and reappraisal projects have disposed of some materials collected before that date

\footnotetext{
${ }^{49}$ Adkins, "Development of Business Archives," 14. See an early review of Southern business records gathered at the University of Kentucky in T. D. Clark, "Records of Little Businesses as Sources of Social and Economic History," Bulletin of the Business Historical Society, 19:5 (1945), 151-58. A good review of the state of business repositories in the early 1970s is in Brichford, "The Relationship of Records Management Activities to the Field of Business History," 220-32.
} 
- much of the important collecting work of these institutions was completed by 1983 and the repositories had settled on the general scope of their collections. The decision-making of the institutions and staff during the founding and early collecting periods critically affected what has been preserved and made available to researchers and what has been lost.

Because this study focuses on the establishment and rapid growth periods of the four repositories, it provides only cursory remarks on their post-1983 histories. This is certainly not to say that significant and interesting work was not completed after 1983. The purpose of this dissertation is not, however, to chart the complete history of these archives, but to examine their founding and early periods of rapid growth. The work of these institutions after 1983, while interesting, must await future study by other researchers.

\section{Methodology and Comparative Themes}

Following a historical narrative methodology, this research utilizes a case study approach to consider the varying institutional contexts that influenced appraisal and selection activities at these four American repositories during their formative years. Documenting the particular contexts which influenced their early manuscript acquisitions activity, this study compares and contrasts the appraisal and selection processes employed at each, revealing how these factors created the collections that survive for research today.

This study documents how each institution initiated their manuscript collecting activities and considers each repository's founding purpose, the mission of its parent institution, and model institutions it aspired toward. It examines the intended users/uses that each repository initially expected of/for its manuscript collections, both internal and external. Archival records of industrial businesses often present unique challenges to archivists: Wide format drawings, voluminous routine accounting files, preservation issues inherited with documents removed from factories and process facilities, and questions about their research value and potential for use. In some cases, appraisal and 
selection decisions were the result of deliberate plans; in others, manuscript acquisition was initially ad hoc and opportunistic. This study will show how the differing missions and directions of these repositories are reflected in the collections they gathered.

This study also examines the partner agencies and networks each repository engaged during its early collecting activities. Each repository interacted with national business historical societies, historians working in the fields of business and economic history, or, in one case, an academic alumni network of businessmen and leaders of industrial corporations. Staff at these repositories also connected to emerging associations of professional librarians, archivists, and museum professionals. This study reveals how these partner agencies and networks provided avenues for manuscript acquisitions while also creating forums for discussion of the uses and value of the materials themselves.

This study considers staff employed for this work. The education and experience of each repository's employees guided collection policies and specific decisions. Staffing at the four case study repositories included varying combinations of economic historians, museum curators, librarians, archivists, engineers, and people with direct industrial work experience. This research reveals how the backgrounds, education, and experience of staff influenced the specific manuscript materials preserved at each site.

\section{Comment on Source Material}

This work draws upon published institutional histories, internal administrative documents, and oral interviews with curators, archivists, and librarians associated with each repository. The study also touches on sources in the history of American business and industry, material culture and heritage management, museum studies, and archival management. Each of the four case study repositories offered different types of source material to support this research. Perhaps, ironically, this study reveals that professional archivists, librarians, and museum curators are surprisingly weak in documenting their own practices and institutional histories. Although some institutions published collection guides and encouraged their staff to publish in professional journals, it is rare for internal administrative records, such as collection policies, minutes of collection development 
committees, or registrar's accession records, to be formally processed and made available to researchers. Like many private industrial corporations, some manuscript repositories are cautious about opening their own institutional records and policies to external researchers. Although legitimate concerns for donor privacy concerning acquisitions and transfers exist, such policies present obstacles to research and publication on archival history.

Thus, access to the four repositories' administrative records varied. As a federal agency, Smithsonian's National Museum of American History regularly transfers inactive internal records and the office papers of retired curators to the Smithsonian Institution Archives, a separate archival repository documenting the history of the Smithsonian's family of museums. In addition, staff within the museum maintain some current and historical files for immediate reference. Hagley and The Henry Ford have created institutional records programs and have processed collections of inactive records and make them available to researchers. Baker Library is the least proactive in this regard, offering no public access to its internal administrative records of any era. Perhaps not surprisingly, all were protective of their case files, accession records, and donor files. Two of the repositories declined requests by the author to work with staff to access such records in compliance with standards for scholarly discretion for research and publication.

Oral interviews with archivists, curators, librarians, and other participants helped to fill some gaps in the archival record. Retirees and current staff from Smithsonian and The Henry Ford provided critical commentary on their work and that of their predecessors. Some individuals contacted by the author were unwilling to share comments "on the record" about their experiences. Unfortunately, many of the key participants in the early development of these four repositories are now deceased. While an obvious problem for Baker Library - with the earliest temporal timeline of the case studies - the author also failed to reach several key participants who have only recently passed, such as former Hagley librarians and archivists Richmond Williams and Michael Nash who died in 2014 and 2012, respectively. 
In addition to primary source materials and oral interviews, a varying amount of published material describes the development and operation of the four case study repositories. Each has published collection guides and promotional materials, while also receiving coverage from media sources about their work. Most valuable to this research, however, have been the articles and monographs published by archivists, librarians, and curators employed by each institution. While some individuals, such as Henry Edmunds at The Henry Ford, only produced one or two important pieces, others such as Michael Nash at Hagley, and Arthur Cole at Baker Library, were very active authors. Some of this material may be considered to be primary source material, for it provides detailed descriptions of manuscript processes in place at specific dates at each repository by a person actively involved in its work.

Although the author attempted to apply a common analytical structure to the four case study chapters, the inconsistency of source material available impaired development of a consistent narrative structure. There is no easy template or schema that can be applied equally to all of the case studies. Aside from their shared interest in collecting manuscripts from business, industry, and technology, they are ultimately very different repositories, established in response to different needs, and developing over different timelines. While this has resulted in dissimilar narrative structures for the case study chapters, the concluding chapter provides overarching analysis and commentary.

This study is grounded in the discipline of industrial heritage. While elements of archival and library history are important to understanding the decisions made by the principal participants, the work archives and libraries did and the manuscripts they preserved represent a critical core of the extant record of industry in North America. This analysis of the founding and early development of key repositories collecting in thematic areas related to America's industrial heritage proves the importance of archival records as material culture items, particularly in those cases when they are the only remaining evidence of factories, mines, power plants, railway yards, and other industries which have been removed from the physical landscape. 


\section{CHAPTER 2. FOUNDING AND EARLY DEVELOPMENT OF MANUSCRIPT COLLECTIONS AT BAKER LIBRARY, HARVARD UNIVERSITY, BOSTON, MASSACHUSETTS, 1908-1980}

\section{Introduction}

The collection of business manuscripts at Harvard University is the logical place to begin this study. Held within Baker Library at the Harvard Business School are record collections well known to business historians and historians of technology. They are considered to be the largest accumulation of business records acquired by a private institution for the purpose of research, including more than 1600 discrete collections, comprising 38,000 linear feet of records, and documenting more than 1,600 businesses and entrepreneurs, primarily from the New England region. This collection predates the other repositories in this study and provided an important model for subsequent institutions. The founding and early history of business and industrial manuscript collecting at Harvard can be divided into three major phases: creation, rapid growth, and maturity. The "creation" period saw haphazard manuscript collecting following the Business School's founding in 1908 and its initial acquisition of business archives from the Slater Mills in 1916. A more significant period of "rapid growth" followed the construction of the Baker Library in 1927. This period, directed by head librarian Arthur Cole, saw an explosive period of collecting supported by Business School faculty, Harvard alumni, and members of the Business Historical Society. Following Cole's retirement in 1956, manuscript collecting entered a period of "maturity and stabilization," during which declining resources and lack of space slowed manuscript acquisition. ${ }^{50}$

This case study of Baker Library draws from a limited set of source materials. None of the Library's internal administrative records, such as collection policies, minutes

\footnotetext{
${ }^{50}$ Robert Lovett, "Business Manuscripts at Baker Library," Business History Review, 34:3 (Autumn 1960), 345-346. Baker Library currently holds 1,652 manuscript collections, comprising 37,835 feet, though these figures do not include the holdings of the Harvard Business School Archives; Tim Mahoney, Special Collections Librarian, Baker Library, personal communication, September 6, 2017. Throughout footnotes, "HBS Archives" denotes the repository location for sources from the Baker Library, Harvard Business School.
} 
of collection development committees, or registrar's accession records, has been formally processed and made available to researchers. Requests for access for this study were declined. Because Baker Library is chronologically the earliest of the case studies in this dissertation - much of its core accessions occurred between 1929 and 1956 - none of the key participants survive to participate in oral interviews. As a result, much of this case study relies on published articles and monographs authored by archivists, librarians, and business historians associated with Baker Library. These provide contemporary descriptions of internal processes and policy, collections, and public programming. In particular, librarian Arthur Cole and archivist Robert Lovett were prolific authors, and some of their published material provides adequate substitutes for the inaccessible administrative sources. Finally, printed guides to Baker Library's manuscript collections published in 1932, 1953, 1969, and 1978 provide additional insights into archival materials acquired during each of the three collecting periods. ${ }^{51}$

Harvard University established the Graduate School of Business Administration on March 30, 1908, with its first classes taught on October 1, 1908. It was one of the first business schools in the United States, following closely upon similar schools at the University of Pennsylvania and Dartmouth College. But the new program at Harvard was different. It was the nation's first solely graduate program in business administration. It received initial financial support from Harvard alumni, heads of business enterprises, and educational foundations. The founders wanted to present business as an area for professional training, similar to medicine and law. ${ }^{52}$

${ }^{51}$ The four editions had slight variations in title and authors. For ease of reference, hereafter they will be referred by the simple title List, with an indication of the year of publication. Formally, they are Margaret Ronzone Cusick, List of Business Manuscripts in Baker Library (Boston: Harvard University Press, 1932); Robert Lovett, List of Business Manuscripts in Baker Library (Boston, Baker Library, 1951); Robert Lovett, List of Business Manuscripts in Baker Library (Boston, Baker Library, 1969); and Robert Lovett and Eleanor Bishop, Manuscripts in Baker Library: A Guide to Sources for Business, Economic, and Social History (Boston: Baker Library, 1978). Information about individual collections is also taken from the published finding aids held at Baker Library, described in Harvard's online catalog (http://hollis.harvard.edu), its online archival system (http://oasis.lib.harvard.edu), or shared to OCLC's ArchiveGrid online archival resource (https://beta.worldcat.org/archivegrid/).

52 Elizabeth Altman, "History of Baker Library," in Baker Library and the Harvard Business School, 51-92 (Boston, Massachusestts: Harvard University, Graduate School of Business Administration, 1978), 52; Melvin Copeland, And Mark an Era: The Story of the Harvard Business School (Boston: Little, Brown: 1958), 16, 28; Arthur Cole, "The Evolution of the Baker Library at the Harvard Business School," 1967, 
The founding of the school was set against tensions in higher education (especially among the Ivy League schools) between traditional scholarly programs and more pragmatic training of professionals. Up to this point, business had been considered too "venal" for a college/university setting, and many on the Cambridge campus felt it was not "worthy of Harvard." This attitude required deans, faculty, students, and alumni to demonstrate the program had scholarly value. Most of the faculty for the new business program were poached from other Harvard units, but some alumni and executives from active corporations helped conduct classes. The School also developed its own new faculty lines, including the first-ever professor in business history at any institution of higher learning. ${ }^{53}$

A library function was to be expected within the new School. But in his first annual report of 1909, Dean Edwin Gay noted that both a library and manuscript collection would be developed. By that date, the library already comprised 1,250 volumes, including monographs and periodicals. The report heralded plans for a "systematic and serious attempt to collect unprinted documents relating to business" and already held certain company records. ${ }^{54}$

As the nation's first business archive, at the first-ever graduate school of business education, no models existed to inspire or direct the emerging manuscript collection. In fact, as the library and archives grew, it became the model for others to follow. In its initial years, however, the business collections were simply a subsection of holdings within Harvard's central library system. The collections moved successively through a

HBS Faculty Publications Files, Baker Library, Harvard Business School (GB2.299); and Robert Lovett, "Business Records and Baker Manuscripts and Archives Department," Harvard Business School Bulletin, 57:1 (January/February 1981), 21.

${ }^{53}$ Lawrence Lowell, Harvard professor of government, quoted in Elizabeth Altman, "A History of Baker Library at the Harvard Business School of Business Administration," Harvard Library Bulletin, 29:2 (April 1981), 169, 172-175; Florence Bartoshesky, "Business Records at the Harvard Business School" The Business History Review, 59:3 (Autumn 1985), 476; and Arthur Cole, "Notes on my Early Experiences with the Library of the Harvard Business School," November 12, 1960, HBS Archives Vertical Files, Baker Library, Harvard Business School (E6C 1960.14).

${ }^{54}$ Lovett, "Business Manuscripts at Baker Library," 346; Altman, "History" (1978), 55; and Florence Bartoshesky, "Business Records at the Harvard Business School," The Business History Review 59:3 (Autumn 1985), 476. 
number of Harvard buildings, before attaining a more distinct identity on the top floor of the university's Widener Library in $1917 .{ }^{55}$

Deans and library staff in these early years wrote of gathering "historical materials which would manifest how systems of American business came to exist." To support the scholarly justifications for the School, reports noted that the business library "gave positive encouragement to the exploration of its intellectual domain and to publication in that field." 56

Justifications for a separate business library with a strong historical and archival component were supported by the School's emerging "problem method" or "case method" of pedagogy, which studied the experiences of actual companies and business leaders. This approach drew from similar pedagogy in the Harvard Law School. In brief, faculty and students gathered materials on an actual business situation, discussed and debated them in the classroom, and created written reports for use by subsequent researchers. The approach linked economic theory to everyday business practices by presenting problems as they would appear to a business executive. Eventually, the method combined aspects of the case method of teaching law with aspects of the clinical method of teaching medicine. Harvard's Melvin Copeland, leader in the development of the case method, wrote that students were presented with real-world problems and factual detail sufficient to allow the students to "put themselves in the position of actual executives and to develop their own decisions." 57

In 1911, the School created a "Bureau of Business Research" to coordinate the creation and maintenance of case materials for instruction. Although based on actual business enterprises, the case studies disguised company names in their final form. The School's first field case, for instance, considered challenges in work routines and labor relations at a shoe manufacturer, referred to generically as "The General Shoe Company."

\footnotetext{
${ }^{55}$ Lovett, "Business Records and Manuscripts" (1981), 21; Cole, "Evolution," 4; Elizabeth, "History of Baker Library" (1978), 52.

${ }^{56}$ Cole, "Notes," 7; Cole, "Evolution," 3.

${ }^{57}$ Quoted section is from Copeland, And Mark an Era, 255. See also Altman, "History" (1978), 55; Lovett, "Business Records and Manuscripts" (1981), 21; Altman, "A History" (1981), 173-175; and Copeland, And Mark an Era, 263-65.
} 
The Bureau also developed its own research initiatives, the first of which was a detailed study of the operating costs of retail shoe stores. It subsequently examined the retail grocery trade, department stores, and variety stores, providing the first in-depth studies of the structure and economics of retail commerce. ${ }^{58}$

Copeland, who headed the case study effort, created a "case book" for the graduate course in marketing. He gathered problems from situations he encountered in his research work, from reports from business publications, and also from his own wartime work in Washington. Beyond these initial "armchair" cases, developed from the comfort of their Harvard offices, Copeland and other program faculty soon pushed more actively off campus and into the business world (often through their network of alumni) to develop actual "field" cases. 59

The Bureau employed recent graduates from the program to seek appropriate materials on topics specified by the teaching faculty. They established contact with a variety of companies from which source material could be collected and cases written. The case studies developed from these materials also incorporated content from the library's holdings - and often included reproductions of print and manuscript material. While haphazard in approach, these processes helped to grow the Library collection. By 1924, the bulk of instruction in most courses in the School used the case system. ${ }^{60}$

\section{Creation of Baker Library, 1908-1927}

Baker Library's "Creation” period of haphazard manuscript collecting dates from the Business School's founding in 1908 and culminated in 1927 with the construction of a new library building and key directional and staffing changes. As noted above, the case study approach and its need for source materials had an early impact on the Library's development. Edwin Gay, the first dean of the School of Business, imagined a central

\footnotetext{
58 Copeland, And Mark an Era, 210-212.

59 Ibid., 75.

${ }^{60}$ Lovett, "Business Records and Manuscripts" (1981), 21; Altman, "History" (1978), 58-57; Altman, "A History" (1981), 176; and Copeland, And Mark an Era, 76, 227-238.
} 
role for the library - and unpublished manuscript sources - in the emerging case method of teaching.

To ensure that business perspectives were central to the Library's development during this creation period, staffing selections often favored men with business experience rather than formal library training. Although many support staff arrived with library training or experience, Business School administrators believed that the leadership positions, particularly the manager or head librarian, had to have a background in business to understand what needed to be collected. Dean Gay feared that "a technically trained librarian would spend more effort on library techniques and the mechanics of cataloging than on analyzing and securing the sort of material" which the library should be collecting. Gay also hoped librarians with a business background would retain contacts they had made in the business world - as a source of financial support as well as collections. As a result, the Business School library employed staff from varying backgrounds during this early period. ${ }^{61}$

Charles Eaton was the first head librarian of note. A 1902 Harvard graduate, Eaton had a career in publishing, including ten years in the publications bureau of the General Electric Company. Dean Wallace B. Donham (who replaced Dean Gay in 1919) hired Eaton to head the Business School Library in 1920. Donham acknowledged that while Eaton lacked any formal library training, he accepted the position "largely as a matter of service" to the School and would bring "just the business contacts necessary to build up the sort of library" that the School needed. ${ }^{62}$

Eaton established the early staffing and administrative structures of the fledgling library and built its collections. Although he initially eschewed employing experienced librarians, he later came to appreciate their work. Eaton operated on the belief that the library could become a substantially self-sufficient institution, practically independent from the other Harvard Libraries. Even at this early stage, he developed the "hazy notion"

\footnotetext{
61 Altman, “A History” (1981), 173, 175; and Altman, "History” (1978), 55.

62 Quoted section is from Altman, "History" (1978), 59. See also Bartoshesky, "Business Records," 477; Copeland, And Mark an Era, 60; and Altman, "History" (1978), 59. Arthur Cole often used quotation marks when referring to Eaton as a "librarian," see Cole, "Evolution," 5.
} 
that the library would grow to be a large, multi-wing building, expanding to house growing print and manuscript collections. With this vision, Eaton did not feel that the library needed a closely-defined collection policy. The scope would be national as an allinclusive archive for business documents, and he showed little concern for duplication or overlap with the collections of other Harvard libraries. ${ }^{63}$

Most commentators note Eaton's "zealous" collecting, the more forgiving describing him as an "enthusiastic collector" and the more caustic depicting an "omnivorous and not always discriminating collector." Under Eaton, the library began to aggressively collect book and serial items, financial documents from noted corporations, and other printed literature. His interests were not confined to nineteenth and twentieth century American business materials, but extended initially to anything and everything that touched on commerce, even back into antiquity. He was not averse to stepping somewhat outside the "proper province of a business library," sometimes wantonly collecting items such as bibles, early federal documents, and miscellaneous official foreign documents which had nothing directly to do with business. ${ }^{64}$

One of Eaton's successes was the establishment of a "Company Collection," comprising materials relating to specific corporations of interest to Business School faculty. Simply arranged by company and grouped by industry, the collection corralled a variety of manuscript and quasi-published items such as annual reports, investor reports, internal white papers, and softbound and pamphlet-style company histories (this material would become more popularly known to librarians as "grey literature" in the 1970s). The company collection provided a convenient place to file items arriving with the developing case studies. Staff gave little attention to recording the source, or provenance, of individual items, including many singular manuscript pieces. Individual company files tended to be reactive in nature, containing only those specific items which had been

${ }^{63}$ Cole, "Evolution," 5-6; Cole, "Some Details on the Determination of The Proper Areas for Collecting Activity at Baker Library," January 16, 1961, HBS Archives Vertical Files, Baker Library, Harvard Business School (E6C 1960.14), 18; and Cole, "Notes," 8.

${ }^{64}$ Quoted section is from Altman, "History" (1978), 59. See also Cole, "Evolution," 5-6; Arthur Cole and Laurence Kipp, "Baker Library Loses a Helmsman," Harvard Business School Bulletin, 39:2 (April-May 1963), 21; and Cole, "Notes," 8. 
received, with little proactive effort to consistently represent firms through some common template of documents. One staff member, "Miss Holt," was assigned as curator and tried to absorb everything that was sent her way by Eaton and others. The collection did not embody a systematic approach to representing the entirety of the business world, but was used in the compilation of case studies for the Business School with files crossreferenced to the numbered cases. ${ }^{65}$

In these early years, the business library had no policy or established practice for collecting and organizing manuscript materials. "The lack of such a policy was not considered a problem," noted Bartoshesky, "since at this early date no one wished to exclude possible source materials." Because Baker Library was the first business archives, and business history had not yet developed as a distinct field of study, it had no models to draw from - or cautions to restrict its collecting. ${ }^{66}$

In the 1920s, Eaton and others at the Business School did not comprehend the overwhelming volume and types of business manuscripts which might be collected. Eaton believed that little had survived across the nation - and that the Library could develop into a national storehouse for these records: "No one at the time had any wellbased notion of the bulk of business manuscripts that lay here and there around the country," a later librarian noted. "No one knew whether business enterprises would or would not give their older materials gladly to such an institution ... and no one comprehended how business manuscripts ought to be prepared for permanent preservation." ${ }^{67}$

Even library staff with some training were unsure how to handle business manuscripts. "Someone persuaded Mr. Eaton to apply to business documents the same sort of technique that was being used in other historical archives, such as those containing the papers of George Washington or Abraham Lincoln.” As a result, Eaton's staff

\footnotetext{
${ }^{65}$ Cole, "Some Details," 1-3 9, 11; Cole, "Evolution," 9; Cole, "Notes," 5; and Lovett, "Business Records and Manuscripts" (1981), 21.

${ }^{66}$ Bartoshesky, "Business Records," 477; Cole, "Notes," 6; Cole, "Some Details," 9; Cole, "Evolution," 10.

${ }^{67}$ Quoted section is from Cole, "Notes," 6. See also Cole, "Evolution," 9.
} 
initially described papers of business enterprises at the item level in a "calendar" system of detailed document abstracts, in line with the historical manuscripts tradition. ${ }^{68}$

Eaton relied on an expanding network of people to identify and assist with acquisition of manuscript collections. He sent Howard Corning, who had worked in the public utility sector before coming to the library, out on collecting trips. Corning secured a variety of "papers supposedly available for acquisition by anyone who asked and came with proper credentials" including collections from San Francisco, Atlanta, Baltimore, and even the iron and copper mining districts of Michigan's Upper Peninsula. ${ }^{69}$

As Dean Gay had hoped, Eaton also used his contacts in the business world to locate collections. The teaching program of the Harvard Business School relied on a strong relationship with the business community. Business executives helped to conduct classes, host graduate student tours and internships, and provide placement to graduates of the program. These businessmen and their corporations also became targets for records acquisition. More than 30 firms with links to the School's educational program donated business records. $^{70}$

As word spread of the Business School's interest in historical material, some libraries and professional societies offered to transfer materials that were somewhat outside their fields of interest and seemed to belong more properly in a business collection. These included collections from the Boston Public Library, the Maryland Historical Society, and the Boston Athenaeum. The New England Historic Genealogical Society deposited its papers from John Hancock, records of his mercantile and trade ventures, and those of his immediate family members. ${ }^{71}$

Eaton envisioned the library growing to physically house complementary records of other organizations in the field of business and economic history. For instance, he helped nurture the Library's early relationship with the Business Historical Society,

\footnotetext{
${ }^{68}$ Quoted section is from Cole, "Notes," 6. See also Cole, "Some Details," 9; and "Calendar (archives)," Wikipedia https://en.wikipedia.org/wiki/Calendar (archives) accessed February 20, 2017.

${ }^{69}$ Cole, "Evolution," 10.

${ }^{70}$ Bartoshesky, "Business Records," 476.

${ }^{71}$ List (1932), v, 70-71. The Hancock collection was later returned to the New England Historic Genealogical Society in the 1970s for a bicentennial exhibit. Baker Library purchased the collection outright in 1992.
} 
though the major results of this relationship would occur after his departure (see below). His more significant involvement with the Railway and Locomotive Historical Society (R\&LHS) provided mixed returns. Established to draw attention to American rail history, the R\&LHS was concerned at the loss of records as World War I drove up the price of scrap paper, encouraging some railroads to dispose of old records. The group began publication of its popular Bulletin in 1921, which featured articles, reproductions of documents, and reference to manuscript collections relating to the development and history of the railroad industry. ${ }^{72}$

Eaton pursued a collaborative relationship with the R\&LHS, hoping the Society would help acquire historical records to expand the library's manuscript collection. Society president Charles Fisher was helpful in securing printed materials, and the Society did play a role in the acquisition of records from the Connecticut River Railroad and the order books of the Taunton Locomotive Works. Beyond those, however, the Society failed to acquire the records of "noteworthy" railroad men which Eaton had hoped to secure. $^{73}$

Of even more questionable value, however, was the arrangement Eaton made to provide office and exhibit space to R\&LHS in the Business School library. The exhibit primarily comprised photographs and printed materials, with a few three-dimensional artifacts. Hoping the library might secure direct financial support from the Society, Eaton signed a contract making the exhibit space a permanent part of a proposed new library building. Subsequent library leadership inherited this "fifth wheel," complaining that the Society rarely had staff in the building and few visitors were interested in its museum

${ }^{72}$ R\&LHS incorporated in 1925, and membership grew to nearly 300 in its first decade. The Society established sections not only in New England, but in the Midwest, Pacific Coast, Canada, and England. Membership included history-minded individuals of all backgrounds, including railroad officials and business executives concerned with the disposition of their historical records, see Charles Fisher, "The Railway \& Locomotive Historical Society, Inc.” Bulletin of the Business Historical Society, 8:5 (October 1934), 77. The organization has been in continuous operation since 1925, with the name of its magazine changed from Bulletin to Railroad History in 1972, see "Railway \& Locomotive Historical Society, Inc. - History," http://rlhs.org/General/history.shtml, accessed February 27, 2016. See also Cole, "Some Details," 18.

${ }^{73}$ Fisher references these collections, which survive in Baker Library's collections as the Stone and Harris Records (3 linear feet, 1845-1888), and Records of Locomotive Builders (2 linear feet, 1847-1937). See Fisher, "The Railway \& Locomotive Historical Society, Inc.," 80; and Cole, "Some Details," 18. 
display of "old bells, tickets, conductor's badges, and samples of rail." Later library heads allowed the relationship to whither, with the artifacts dispersed to several museums and the manuscript materials retained at Baker. ${ }^{74}$

Even without access to the detailed accession records of the Library, one may still comment on the impact that the "Creation" period had on Baker's manuscript collection. One useful source is the List of Business Manuscripts in Baker Library collection guide published in 1932. Created ostensibly as a research support tool, this and subsequent guides also served as important promotional publications in an era before online catalogs, electronic finding aids, and internet search engines. ${ }^{75}$

Staff claimed that the 1932 List was the "first item of its sort to be published in the United States if not the world." It described 508 discrete collections. Although entries were neither consistent nor comprehensive, most provided five descriptive elements: (1) the primary industry relating to the content, (2) the temporal period covered by the material, (3) the names of firms represented in the collection, (4) the geographic location of the firm and/or its facilities, and (5) an indication of the size of the collection. Nearly all acquisitions were included, regardless of their status. Collections already arranged and inventoried by Library staff were represented by detailed descriptions, while brief entries reflected those which had yet to receive "sufficient research" about their contents. The goal of the cursory entries was to alert researchers to the existence of the collection within the Library's holdings. ${ }^{76}$

The entries were arranged by industry "in logical rather than alphabetical sequence" beginning with generic industries and working through extractive, manufacturing, engineering and construction, marketing and financial services, and governmental agencies. Within each industry, collections were listed in chronological order by the earliest dated item in each collection. This arrangement by industry and date became a key element in the organizational schema developed by the Library (more on

\footnotetext{
${ }^{74}$ Description of museum display is from Cole, "Some Details," 18. See also Fisher, "The Railway \& Locomotive Historical Society, Inc.," 79-80.

${ }^{75}$ List (1932).

${ }^{76}$ Cole, "Some Details," 11; and List (1932), vi.
} 
this below) and was predicated on a belief that researchers would want to compare and contrast business practice sequentially over successive decades. ${ }^{77}$

While entries in the 1932 List included some collections acquired after Charles Eaton's departure, it is still possible to identify the range of materials most likely acquired during his time as head of the library. Collection descriptions indicate how the Business School's primary interest in economic history translated into an early emphasis on accounting and financial records. Entries often provide numeric totals for "volumes" in a collection, referring to individual bound accounting volumes, such as ledgers, journals, waste books, cash books, and stock registers. For manufacturing firms, the collection descriptions indicated some labor and pay rolls and some production records, but the entries don't include such workforce information in other sectors of business. Eaton appears to have been less interested in administrative correspondence, although reference is made in some entries to collections of "unbound manuscripts" that included incoming letters. Descriptions in the List, however, rarely mention general administrative correspondence, with much of what was described linked to transmitting contracts, discussing deeds, and fulfilling orders. Thus, accounting and financial records were by far the more substantial and obvious content of early acquisitions. ${ }^{78}$

The 1932 List also reflects Eaton's willingness to take whatever came across the transom. Individual volumes represented business ventures of all shapes, sizes, and sectors: Farmers, leather merchants, hotels, sawmills, gristmills, sailing ships, postal service, retail groceries, banks, and day laborers. Although some materials contained information on national ventures and international trade by American businesses, most of the small collections came from ventures in the New England region.

Amongst the chaff, however, Eaton's staff acquired many genuinely valuable kernels. Of particular note were records of individual shipping merchants and international shipping firms gathered under the heading of "Marketing Services." These

\footnotetext{
${ }^{77}$ List (1932), vi.

78 The 1932 List provides indications of the donors for most collections, including any association they may have had with the Business Historical Society. Because the Business Historical Society was founded in 1925, one may assume that anything credited to that organization comes after that date.
} 
included the personal papers and business records of Israel Thorndike, "the outstanding Beverly merchant" (5 linear feet, 1778-1899), John Jacob Astor (7 linear feet, 17841892), and materials relating to the business ventures of Jay Cooke (40 linear feet, 18321915) (though the 1932 List acknowledged that most correspondence and "the important papers" of Cooke were held by the Pennsylvania Historical Society). Eaton did acquire several larger industrial collections, including the Fall River Iron Works (54 linear feet, 1821-1909) and the rum manufacture and transatlantic trade records of the Heard Family (400 linear feet, 1754-1898). ${ }^{79}$

Yet, the library's most significant acquisitions of manuscript records before 1927 came from the New England textile industry. The earliest textile accession came in 1916 with the records of the Slater family of businesses (246 linear feet, 1793-1926), which included the records of more than two dozen intertwined firms. Other textile firms soon donated or deposited their records at the Library. By 1932, the textile manufacturing collections included more than three dozen firms and included large collections from the Lawrence Manufacturing Company (125 linear feet, 1831-1955), the Dwight Manufacturing Company (150 linear feet, 1832-1927), the Allen-Lane Company (153 linear feet, 1853-1941), and Lyman Mills (201 linear feet, 1833-1936). As with the records of other business firms at the library, the textile collections consisted primarily of bound financial accounting books and few examples of letter books, correspondence, blueprints, or general administrative records.

In the days following World War I, Eaton "reigned" from an office atop the Widener Library building. Observers noted that he was not "accustomed to library work" and found more enjoyment in the hunt for materials rather than their organization, description, and use. Coworkers commented that Eaton "lost interest in the books or other items when they arrived within the walls of the building." "The materials had overflowed ... and spilled out into the reading rooms nominally assigned to the Classics Department of Harvard College.” Dean Donham received increasing pressure from the faculty to

\footnotetext{
${ }^{79}$ Cole and Kipp, "Baker Loses a Helmsman," 21.
} 
remove Eaton, though it would take the construction of a new library building for Donham to finally implement significant staffing changes. ${ }^{80}$

Under Eaton, the Business School's collection was "rich but chaotic." Yet Charles Eaton was successful in creating a business library collection unlike that at any other institution. While he failed to properly manage acquisition budgets or to create a focus which might be sustainable, Eaton established the Harvard Business School library as the nation's first business manuscript collection. Its first printed guide to collections referenced more than 500 separate collections and announced to the scholarly world that it intended to continue along this path for the foreseeable future. ${ }^{81}$

\section{Rapid Expansion of Manuscript Collections, 1927-1956}

The single most active period of growth of the manuscript collections at Baker Library began in the late 1920s and was encouraged by three significant events: the construction of a purpose-built library on the new business school campus in 1927, an immediate increase in collecting facilitated by the new space and the work of the Business Historical Society, and the employment of Arthur Cole in a library leadership role beginning in 1929.

The School of Business had achieved a surprising amount of success in its first two decades. Yet, its faculty, classes, and library collections were still situated in borrowed spaces in buildings designated for other programs. In the early 1920s the School's supporters decided to finance and build an entirely new Business School campus south of the Charles River, separate from the main Harvard campus. Support for the endeavor came from many sectors, including alumni, but it was George Baker, president of the First National Bank of New York, who provided the primary funding. Although one of the most successful and most highly respected businessmen in the United States, Baker was not a Harvard alumnus - in fact, he had never attended any college. When Baker was approached for a \$1 million gift, he responded with a pledge of

${ }^{80}$ Cole and Kipp, "Baker Loses a Helmsman," 9, 21.

${ }^{81}$ Bartoshesky, "Business Records," 481; and Cole, "Evolution," 6. 
\$5 million, desiring his name to be associated with "the first Graduate School in business in the world." 82

Construction of the new campus began in 1925 and included dormitories and an administration building. A dedicated library structure, named in honor of George Baker, stood at the center of the complex. Although the building did not meet staff expectations initially - work spaces were inconveniently located in relation to reading rooms and classrooms - the building still created an identifiable and iconic physical space for the Library's growing collections. Baker Library and the adjacent buildings were dedicated on June $4,1927.83$

The opening of the new library supported an important manuscript collecting collaboration with the Business Historical Society. In the early 1920s, Dean Donham, his lieutenant George Woodbridge, and Charles Eaton cultivated close ties with business leaders concerned with the preservation of business records to marshal support for the Business School and its new campus and library. Noting the seeming disinterest of historical societies in such records, these historically-minded leaders noted with dismay that firms were throwing away "tons of material" from their offices, "material which told an interesting, valuable story of the growth and accomplishment of American business."84

Under Woodbridge's leadership these businessmen formed the Business Historical Society (BHS) in 1925 "for the purpose of collecting and preserving the literature and records of commerce, finance, and industry." Charles H. Taylor, manager and treasurer of The Boston Globe, was the first BHS president and one of its most generous donors. The group had four interrelated goals: 1) Discover and preserve business records, 2) Devise ways to classify and catalog these records, 3) Promote the study of the history of business, and 4) Assist in the publication of business history. Organizing committees were established across the country, and the list of founding

\footnotetext{
${ }^{82}$ Copeland, And Mark an Era, 70.

${ }^{83}$ Copeland, And Mark an Era, 70-73; Cole, "Evolution," 5; and Altman, “A History” (1981), 176.

${ }^{84}$ Quoted section is from page 2 of "The Business Historical Society and the Harvard Business School," unpublished typescript, Carton 1 Folder, "BHS - History of Business Historical Society," Business Historical Society Records, HBS Archives, Baker Library, Harvard Business School. See also Cole, "Some Details," 9.
} 
members included a veritable who's who of Boston businessmen, Harvard alumni, and business leaders from other key cities. Membership in the Society was certainly not limited to graduates of Harvard University, although founding members Arthur Cole and Howard Corning encouraged participation by Harvard alumni. "It is hoped that Harvard men everywhere will be interested to know," Corning wrote, "that there is now a place in the university where business records and data of all kinds will be treasured." 85

By 1928, the Business Historical Society counted more than 320 members. In support of its mission to preserve and promote business history, BHS held regular meetings, issued press releases on a variety of causes, sponsored direct-mail campaigns, and held joint meetings with the American Historical Association and the Economic History Association. Its key publication, The Bulletin of the Business Historical Society, was begun in June 1926, informing members and the larger business community about how the Society was "advancing popular understanding of business." Articles highlighted specific business record collections which had been preserved, encouraging both businessmen and archivists to help in this work. ${ }^{86}$

Rather than simply serve as a passive historical society with meetings and a journal, BHS committed itself to "actively assist in preserving business archival material for future generations." Members recognized that material was quickly disappearing and that a "professional attitude" to its preservation was lacking. Previous efforts had failed, they claimed, due to lack of capital required to house such a collection. A group of

${ }^{85}$ Quoted section is from Howard Corning, "The Collection of the Business Historical Society at Baker Library." Bulletin of the Harvard Business School Alumni Association, 5:4 (April 1, 1929), 153. See also N.S.B. Gras, "Past, Present, and Future," 1-12; Bartoshesky, "Business Records," 477; Altman, "History" (1978), 60; "The Business Historical Society and the Harvard Business School," Lovett, "Business Manuscripts," 346.;"The Business Historical Society Formed by American Business Men," unpublished typescript, Carton 1, Folder 1, "BHS - History of Business Historical Society," Business Historical Society Records, HBS Archives; "The Founding Members of the Business Historical Society, Incorporated," unpublished typescript listing, Carton 1, Folder "BHS - History of Business Historical Society," Business Historical Society Records, HBS Archives; and "Charter of The Business Historical Society, Incorporated," Harvard Business School Alumni Bulletin, 1:1 (June 1926), 11-16.

${ }^{86}$ The Bulletin was continued as the Business History Review, which has been published directly by the Harvard Business School since March 1954, see N.S.B. Gras, "Past, Present, and Future," 4; Bartoshesky, "Business Records," 479; Lovett, "Business Records and Manuscripts" (1981), 21; and Hidy and Hidy, "Henrietta Larson: An Appreciation," 8. 
businessmen, such as the founders of the BHS, and an academic institution, such as Harvard's Graduate School of Business, were ideal to redress the situation. ${ }^{87}$

To a large degree, therefore, the early mission of the Business Historical Society was predicated on the ability to house manuscript materials at the School. There is little doubt that the initial work of the Society was made known to George F. Baker as he was considering his support for the new campus buildings and library. Not long after completion of the structure, the School and the Society signed a contractual agreement which named Baker Library as the official depository for historical materials BHS members might acquire. The contract stipulated that the University would provide staff "trained in the special techniques required" of such a repository. ${ }^{88}$

The Business Historical Society promoted Baker Library as the place for the nation's business materials, with a comprehensive collection of print, manuscript, and grey literature documenting the "financial, commercial and industrial development of the world." There would be a "greater benefit to business through such a centralization of data," the organization announced, "instead of the present scattered method in small individual libraries or segregated collections." BHS members promoted Baker Library's facilities and specialized staff as unique for the cataloging needs of business records and that records placed there would see active use by Harvard students as part of the School's emerging case system of teaching. ${ }^{89}$

The 1927 completion of the new Baker Library building created the opportunity for a rapid increase in collecting. Calls went out to both members and potential members, encouraging them to contact the Library if they found materials in their own collections or to lawyers, bankers, and other professionals within their ranks who found such

\footnotetext{
${ }^{87}$ Corning, "The Collection of the Business Historical Society at Baker Library," 149; and George Rich, "Our Primary Purpose." Bulletin of the Business Historical Society, 1:1 (June 1926), 2.

88 "The Business Historical Society Formed by American Business Men," 1; Cole, "Notes," 13; and George Rich to Samuel Rea, December 10, 1925, Carton 1, Folder "BHS - History of Business Historical Society," Business Historical Society Records, HBS Archives.

89 "Charter of The Business Historical Society, Incorporated," 11-16; and "The Business Historical Society Formed by American Business Men," 2.
} 
materials through interactions with their clients, many of whom were going through bankruptcy and liquidation. ${ }^{90}$

Initially, the Business History Society did not wish to place boundaries on what might be acquired, and it considered potentially valuable business records from all historic periods, all geographic areas, and all industries. Its early promotional literature was broad in scope:

to collect, preserve, and make available for business, economic and historical study, not only books but also records of corporations and partnerships, ship logs, and other original source data, in fact, every sort of valuable destructible data relating to commerce, finance, and industry. ${ }^{91}$

Although Arthur Cole and his staff would later attempt to limit Baker Library's collections, BHS members continued to collect broadly. Even as late as 1938, Harvard Professor Ralph Hower was still encouraging casting a wide net. "Because of our location it is true that most of our material relates to New England," he wrote to a colleague and potential donor, "but we are eager and willing to preserve business materials relating to other parts of the country or even in foreign countries."92

The Society's Bulletin became a potent tool in this collecting activity. It highlighted the holdings of Baker Library, with new accessions and processed collections described at length in its issues. Editors hoped to encourage prospective manuscript donations by publishing detailed descriptions of gifts and newly opened collections, such as volumes of London banking magazines, a "valuable deposit" of information about Boston shipping lists from 1843 to 1878, and manuscript records of the Central Wharf and Wet Dock Corporation. ${ }^{93}$

The response to these calls was significant, with members shepherding business manuscript donations from across the nation. While most materials were outright gifts,

\footnotetext{
${ }^{90}$ Lovett, "Business Manuscripts," 346; and Robert Lovett, "Business Records in Libraries," The American Archivist, 20:3 (1957), 383.

${ }^{91}$ George Rich to Samuel Rea, December 10, 1925, Business Historical Society Records, HBS Archives.

92 Ralph Hower to Alston Field, July 20, 1936, Carton 1, Folder "Business Historical Society Acquisitions suggested 1929-1941," Business Historical Society Records, HBS Archives; and Bartoshesky, "Business Records," 478.

${ }^{93}$ List (1951), iv; and "The Business Historical Society and the Harvard Business School," 2.
} 
some collections came as deposits from still-active corporations, and others were purchased from donors using funds raised by the membership of the Business Historical Society. For a time, BHS coffers supported a paid agent to seek out available business records. In all, these efforts resulted in nearly half of all manuscript material collected by Baker Library during the 1920s and 1930s. ${ }^{94}$

The List publications were careful to describe and acknowledge donations directed through the BHS, often indicating the specific donor's name. The initial 1932 edition identified more than 210 collections (more than 1/3 of all holdings) as being routed through the BHS. Charles Taylor, president of the Business Historical Society, played a singular role. This "incorrigible collector" was responsible for more than half of all acquisitions ascribed to BHS in the 1932 List. His place in New England business, civic, and social life provided access to a wide variety of businessmen, collectors, and established families - as well as their historical records. Holding "no interest in, or patience with, the intellectual problems connected with business history," Taylor's acquisitions reflected his personal historical interests. Almost all initial acquisitions in the "Marine Industries" section came through Taylor, comprising hundreds of ledgers and log books from dozens of fishing, shipping, whaling, and shipbuilding firms. Taylor helped to diversify the holdings to cover many smaller retail, professional offices, and personal service enterprises, everything from the Boston law firm of Sohier and Welch (2 linear feet, 1833-1883) and the Exchange Coffee House (1 ledger, 1821-1839), to an account book for blacksmith Nathaniel Chamberlin (1 volume, 1743-1775) and a record of medicines and drugs sold to doctors by Redford Webster (1 volume, 1784-1787). The importance of the Business Historical Society and Charles Taylor cannot be undervalued. ${ }^{95}$

Beyond its new building and work with the Business Historical Society, however, Arthur Cole, who joined the staff in 1929 and would lead the program until his retirement in 1956, was the most important influence on the "growth" period in manuscript

\footnotetext{
${ }^{94}$ Cole, "Evolution," 10; Lovett, "Business Records and Manuscripts" (1981), 21; and Bartoshesky, "Business Records," 478.

${ }^{95}$ N.S.B. Gras, "Past, Present, and Future," 2.
} 
collecting. Cole built a national reputation in business and economic history, corporate records management, and archival process and practice for business records.

Born in Haverhill, Massachusetts, on November 21, 1889, Cole attended Governor Dummer Academy and Bowdoin College, where he wrote and edited both school's newspapers. He entered Harvard University in fall 1911 as a graduate student, receiving masters (1913) and PhD (1916) degrees in economics at the Graduate School of Business. He worked directly with Dean Gay on his doctoral studies. His dissertation examined the history of wool manufacture and the rise of the factory system in the United States and, during his doctoral research, Cole discovered the rich trove of historical records preserved by the Slater textile companies of Webster, Massachusetts. Working with Dean Gay and early managers of the Library, Cole assisted in the acquisition and transfer of the records to Harvard. ${ }^{96}$

Slater was the first large, unified collection of business records acquired by the Harvard Graduate School of Business, and its significance to the repository - and to Cole's career - cannot be understated. Described as "the core" and "the beginning" of the manuscript collection, the handling of the Slater's fifteen hundred volumes created a pattern for many subsequent acquisitions. Perhaps more importantly, Cole's involvement in the acquisition encouraged him to remain interested in the preservation of business records and set the stage for his subsequent work as head of Baker Library. ${ }^{97}$

Yet, Cole's primary career was as a scholar and educator in the field of economic history. Upon graduation from his PhD program in 1916, Cole became a tutor and instructor in economics at Harvard. Military service in World War I interrupted his academic work. Cole achieved the rank of Captain working with the Ordnance Department and the U.S. Tariff Commission. Afterwards he resumed his academic

\footnotetext{
${ }^{96}$ Biographical information is drawn from Robert Lovett, "Arthur Harrison Cole," Proceedings of the Massachusetts Historical Society, 86 (1974), 86-89, and Thomas Cochran, "Arthur Harrison Cole, 18891974," The Business History Review, 49:1 (Spring 1975), 1-5. See also Arthur Cole, "Notes on my Early Experiences with the Library of the Harvard Business School," 5, and Altman, "History" (1978), 63.

${ }^{97}$ Altman, "History" (1978), 63; Altman, “A History" (1981), 180; Lovett, "Business Manuscripts," (1960), 346; List (1951); Lovett, "Arthur Harrison Cole," 87; and "A Conversation with Robert Lovett," Harvard Business School Bulletin, 57:1 (January/February 1981), 19.
} 
position, advancing to assistant professor in 1923, associate professor in 1928, and professor of business economics in 1933.

Cole was a prolific writer and wrote dozens of articles across many different disciplines, provided introductions and forewords to numerous monographs, and authored/co-authored a significant number of his own monographs. He also achieved great success in program administration, serving for 10 years with the International Price Committee, working as editor of The Review of Economic Statistics, and co-publishing the Journal of Business and Economic History. He was a founding member of the Business Historical Society and helped to transition its members' bulletin into the Business History Review. Cole's scholarly work was not without its detractors; his interest in social forces and behavioral science often took his work outside the pale of many mainstream economists. ${ }^{98}$

Cole's academic career was on the rise when Dean Donham appointed him as “administrative curator” under Charles Eaton at Baker Library in 1929. His role was not initially clear, and it is likely that Donham created the job title so as not to offend Eaton. Yet Donham obviously hoped Cole's presence would leaven Eaton's lack of budgetary restraint. Cole was immediately concerned with the Library's lack of "proper objectives" and began to direct change. It wasn't long before the two found themselves at "loggerheads." Eaton resigned "rather than accept a subordinate position," and Donham promoted Cole to head librarian in 1933. In total, Cole would serve Baker Library for 27 years until his retirement from Harvard in $1956 .{ }^{99}$

Dean Donham presumably felt that Cole would be able to bring order out of the chaos created by Eaton's uncontrolled collecting, and Cole's "sailing directions" were "to impart order and suitable objectives to the acquisition policies of the library." Cole claimed that he "was surprised to find himself invited" to take on management of the library, reflecting late in his life that he could recall "no objective foundation for rational selection" for the work. He had no formal library training and "was so ignorant of library

\footnotetext{
${ }^{98}$ Cochran, "Arthur Harrison Cole," 2.

${ }^{99}$ Cole, "Notes," 2, 8; Altman, "History" (1978), 63; and Arthur Cole, "The Impact of a Large Collection of Business Literature," Harvard Library Bulletin, 15:2 (April 1967), 188.
} 
matters and requirements." Cole intended to continue his career as an educator and scholar, so he devised administrative structures to manage the routine operations of the Library. Described as a "master at inspiring his assistants and successfully delegating duties," Cole acknowledged the work of the "capable corps of women assistants" employed at the Library, though some of his writings reflect significant bias toward male staff. 100

Initially, he "joined forces" with assistant Mary Feiss to set up a "logical internal structure" for the Library's operation. One of Eaton's hires, Feiss also lacked formal library training, but claimed to have learned library procedures through "endless correspondence with other librarians." While Feiss enjoyed managing the operational aspects of the library, she did not want to have "any part in determining the objectives of the institution." She developed the operating procedures, order forms, and other ordering/accounting policies which allowed Cole's decisions to be systematically recorded and efficiently acted upon. ${ }^{101}$

Cole undertook a systematic review and restructuring of Baker Library, seeking to rationalize the collections and justify acquisitions policies within the Harvard setting more in line with "the proper objectives of the library." Administratively, Cole created a structure with four operating departments: acquisitions, cataloging, reference, and circulation (Cole noted a "clash of personalities" which kept reference and circulation separate for many years). The acquisitions department maintained records for all materials purchased by Baker Library and included a small staff that collated and bound items. $^{102}$

Alongside these functional departments, Cole established four divisions to handle different aspects of Baker Library collections: the Corporation Collection, the manuscript

\footnotetext{
100 Altman, "A History" (1981), 180; Cole and Kipp, "Baker Loses a Helmsman," 21 ("sailing directions"); Cole, "Evolution," 7 ("surprised to find myself"); Cole, "The Impact of a Large Collection," 191; Cochran, "Arthur Harrison Cole," 2 ("master at inspiring"); and Lovett, "Arthur Harrison Cole," 87 ("capable corps"). Although Cole acknowledged some roles of women, his writings (both published and unpublished) reflect a general gender bias toward male staff, see Cole, "Notes," 10-11, and Cole, "Some Details," 8, 23 ("so ignorant").

${ }^{101}$ Feiss' personal style offended others in the library, however, and pressure from other staff ultimately forced her dismissal, see Cole, "Evolution," 7, 11, and Altman, "History" (1978), 65, 71.

${ }^{102}$ Cole, "Notes," 8, 11; and Cole, "Some Details," 19-20.
} 
division, and two imprint collections held in the Kress and Aldrich rooms at the Library. Each division was responsible for the ordering and care of materials in its collection, as well as coordinating service to the public. Cole attempted to develop a fifth collection division on transportation. He believed that the rise of commercial aviation would encourage research and teaching on the topic, and he gathered materials and set aside physical space for the effort. Although the aviation materials did not receive the use that Cole expected, Baker Library maintained a separate collection for many years. ${ }^{103}$

Late in life, Cole reflected that his operational approach to managing the collections - and staff - relied upon "autocratic power lodged in my own hands." A system of "decision slips" recorded his determination as to whether a donation should be accepted and how staff should handle it. "Nothing was done relative to it until I had ruled regarding it," Cole noted. This top-down authoritarian approach established patterns for acquisition and declination, instructing staff with a level of finality that ensured staff would fulfill Cole's appraisal decisions. Cole acknowledged that this level of control was only possible due to the "modest size" of Baker Library and its focused collecting areas. ${ }^{104}$

Alongside the manuscript collections, imprints - books, serial titles, and other printed items - played an important role. Eaton had been a voracious collector of printed material, and there was a significant growth of the imprint collection under Cole as well. Although emphasizing American business, the collections were also rich in European and other international holdings.

A classification system to organize and physically shelve the book collections was under development when Cole arrived. Librarians working with business materials had long recognized that the three major classification systems - Library of Congress, Dewey Decimal, and that of Charles A. Cutter (a former Harvard librarian who had championed the use of card catalogs in the 1860s) - lacked the specificity needed for a library containing a large specialized business collection. Working with Cutter's nephew,

${ }^{103}$ Cole, "Some Details," 19-21.

${ }^{104}$ Cole, "Some Details," 23. 
William A. Cutter, staff developed a detailed system to classify business literature. Cutter's Industries List, first published in 1930 and expanded and reprinted in four editions through 1949, provided a foundation for the work that he, Cole, and other Baker Library staff used for the organization of business materials of various formats. ${ }^{105}$

The "Baker System of Classification," initially developed as an in-house guide for imprints, drew from Cutter's Industries List and Cole's experience as a researcher and educator. It attempted to group materials in a logical way to support browsing for the types of research Cole expected business students and faculty to conduct (at least by browsing in the card catalog, as patrons could not browse the closed stacks of the Baker Library). The system gave primary consideration to the functional divisions within business activities and the relation of these functions to particular types of business institutions; geography and industrial sectors were given a secondary place in classifying specific pieces. The Baker System created an expandable, structured, call number system which, in turn, established the physical locations for books on the shelf. It was deemed of sufficient value to other libraries that the H.W. Wilson Company, a leading library publishing house, issued a formal edition, A Classification of Business Literature (with foreword by Cole). Looking back later in his career, Cole recalled that he "had never given thought to the notion of library classification" before the project, a reflection on his lack of any background in libraries. The work would inform much of Cole's thinking on business information and the way that collections would be organized and described at Baker Library. ${ }^{106}$

Baker Library created a divided card catalog - still novel at that time - with separate sets of subject and author/title cards. Relying on the Library of Congress subject headings for much of its subject cataloging, the card catalog incorporated elements of the Baker System and expanded its nomenclature for business topics. Cole observed that

\footnotetext{
105 Altman, “A History” (1981), 181; Baker Library, A Classification of Business Literature, (New York: The H.W. Wilson company, 1937), I; and Arthur Cole, "Business Manuscripts: Collection, Handling, Cataloging," Library Quarterly, 8:1 (Jan 1938), 103.

106 Quoted section is from Cole, "Notes," 10. Baker Library's closed stacks are mentioned in Arthur Cole and Margaret Stirling, "Flexibility of the Baker Classification," Special Libraries, 35:6 (August 1944), 336; Cole, "Evolution," 13; Baker Library, A Classification of Business Literature (New York: The H.W. Wilson company, 1937), I; Altman, "History" (1978), 67; and Cole, "Notes," 10
} 
students "made little employment of the author cards," spending most of their time in the subject portion of the card catalog. Staff also maintained a separate shelf-list of cards specifically organized following the Baker classification, which helped staff and researchers to "browse" the collection (particularly portions with closed stacks) and was used during periodic "reading" of the shelved collection to ensure that items were present and in proper order. ${ }^{107}$

After creating the Baker System, Cole and his staff reviewed the library's existing imprint collection, both serial items and monographic material. Publications relating to business were "just too numerous for Baker Library to consider total acquisition" so "it was essential the best possible choices be made." The project saw the re-shelving of the print materials according to the new schema. Staffing billowed from 32 employees at Baker Library to 74 to complete this physical work. ${ }^{108}$

The new Baker Library facility provided room for expansion, and in 1927 a Division of Manuscripts was established in "reasonably adequate quarters." When Cole arrived, he assumed oversight for the division, and all manuscript acquisitions required his approval. A small staff was dedicated to the manuscripts, with internal leadership provided by individuals such as Sophia Glidden (1927-1929), Margaret Cusick (19291933), Alice Lyons (1933-1941), and, immediately following World War II, Carolyn Peeler (1947). ${ }^{109}$

Dean Donham's "large dreams for the library of his school" placed manuscripts in a key role, feeling that historical records were critical to understanding "how the present business system came to exist." In addition to sponsoring interactions with external business, professional, and historical societies, Donham actively sought historical manuscript and imprint collections to help build the collections. Cole's doctoral work with the Slater Mills manuscripts reinforced Donham's belief of the role manuscripts

\footnotetext{
107 Cole, "Evolution," 12; Cole and Stirling, "Flexibility," 337; and Cole, "Some Details," 12, 26.

108 Cole, "The Impact of a Large Collection," 188-89; and Altman, "History" (1978), 91.

${ }^{109}$ Lovett, "Business Records and Manuscripts" (1981), 21; List (1951), i; and Robert Lovett, "Business Manuscripts in the Baker Library," Harvard Library Bulletin, 5:2 (Spring 1951), 256.
} 
could play in Baker Library's development - as well as the role Baker Library could play in informing modern business records practice. ${ }^{110}$

Cole and his staff overhauled Eaton's Company Collection, renaming and expanding it as the "Corporate Records Collection." He believed students and scholars coming to Harvard for research would expect to find records of specific corporations at Baker Library. Under Eaton, however, the collection had been disorganized and materials difficult to locate. ${ }^{111}$

The collection grew to include a wider variety of manuscript documents, imprint items, and grey literature. Thematically, Cole and his staff decided the collection should include information on all Class I railroads and all public utilities. In addition, they identified "634 industrial concerns, 55 insurance companies, 100 banks and other financial institutions, and 15 foreign corporations" to include in the collection. They removed many print items and transferred them into the book collection, and the remaining materials they organized consistently within individual company sections by document types, such as annual reports, financial documents, and other secondary items. Believing the main use of the materials by students and professors would be to trace financial change, staff focused on quantitative sources such as property surveys, inventories, and valuation reports. By 1948, Baker Library was collecting the annual reports and other financial publications of more than 2,500 American corporations. The corporate collection had held many miscellaneous items from various companies, which Cole felt might be overlooked. "It seemed unwise to maintain separate folders for each unit," so he decided to gather like material together into industry folders on topics such as canals and banks. ${ }^{112}$

\footnotetext{
110 Cole, "Notes," 7.

${ }^{111}$ For Cole's detailed review of the Corporation Records Division, see Arthur Cole, "Corporation Material in the Business School Library." Harvard Library Notes (June 1941), 46-53; see also Cole, "Some Details," 1-3.

${ }^{112}$ Quoted section is from Cole, "Some Details," 3. See also Cole, "Corporation Material in the Business School Library," 49; Cole, "Evolution," 9; Arthur Cole, "The Baker Library as a National Research Institution," March 19, 1948, HBS Faculty Publications Files, Baker Library, Harvard Business School (GB2.299); and Cole, "Some Details," 2.
} 
Cole accepted some flexibility in the geographic and structural boundaries of the Corporate Records Collection. From a thematic perspective, the Federal Reserve Banks were excluded as governmental agencies, yet those of savings banks and insurance companies were included. Eaton had allowed some professors' specialized interests to tip the collection more heavily toward railroads and canal companies. With the help of a broader range of faculty, Cole established a more balanced representation, including manufacturing and public utilities, while also expanding to selected foreign companies, particularly Canadian and British firms. ${ }^{113}$

Cole's arrival and his work rationalizing the policies, procedures, and collections of Baker Library coincided with dramatic changes in the nation's economic conditions, presenting both challenge and opportunity for the manuscript collections. The Great Depression of the 1930s restrained University budgets and curtailed collecting outings like those of Howard Corning during Eaton's tenure.

The depressed economic conditions caused the demise of many businesses in the 1930s - and exposed large masses of historical records to destruction. Individuals and corporations seeking a repository to preserve these materials looked to the Graduate School of Business with its new archives. This was particularly true for New England's textile industry and "accelerated the collecting" as New England mills closed or moved work to the American South. Baker Library's already impressive textile collections were augmented by the papers of the Amoskeag Manufacturing Company (314 linear feet, 1831-1936), the Pepperell Manufacturing Company (192 linear feet, 1741-1932), and the Nashua Manufacturing Company (23 linear feet, 1824-1932). Additional corporate gifts from the textile machinery industry included records from the Saco-Lowell Machine Shops (27 linear feet, 1855-1960) and the Whitin Machine Works (81 linear feet, 18431933). Material came in so rapidly that the staff couldn't handle it all, and much was put into crates in the basement for storage. ${ }^{114}$

\footnotetext{
${ }^{113}$ Cole, "Some Details," 5-6.

${ }^{114}$ Robert Lovett, "A Brief Account of the Collecting of Business Records at Harvard University," Bulletin of the Business Archives Council of Australia, (unknown date), 84-86, from the HBS Faculty Publications Files, Baker Library, Harvard Business School (GB2.535); see also "A Conversation with Robert Lovett," 19, and Lovett, "Business Manuscripts," 346, 347.
} 
Cole later admitted that in his early years at the library, everyone was "flying blind" when it came to manuscripts. "No one had the foggiest idea" - not the dean, their colleagues in the Business Historical Society, or even Cole himself. Cole later noted: “[T]he volume of extant business records was really stupendous [and] our library's initial notion of taking over all records for the country was downright idiotic." Cole's 1945 essay, "Business Manuscripts: A Pressing Problem," outlined the changes in office technology, business practice, government regulation, and just sheer expansion of American business fueling the explosion of business records. These experiences and limits in potential space confirmed for Cole that there were far too many business records "laying here and there all over the nation" for Baker to possibly collect. ${ }^{115}$

As a result, Cole and his staff determined to limit Baker Library's manuscript program in both geographic and temporal scope by focusing on business materials from the New England region from the middle of the seventeenth century up to the 1890s. The institution, giving preference to earlier time periods, would look for papers that "were in danger of destruction," were reasonably complete in coverage, or were from "enterprises of economic significance in the region." 116

During the 1920s and 1930s, other university-based archives were becoming more interested in business manuscripts, likely as a reflection of the growing stature of Baker Library. As a gesture of largesse (and a useful way to reduce Baker's holdings) Cole deaccessioned some collections and sent them to other repositories, including Yale, the University of Michigan, the Newberry Library, and libraries in Baltimore and California. Never one to miss an opportunity to laud Baker Library, Cole remarked later that "in a sense, Baker Library served to preserve such collections of valuable documents while certain parts of the country were being educated in their value."117

Baker Library wasn't protected from the fiscal restraints imposed by the Great Depression. The Graduate School, facing severe financial exigencies, discharged a third

\footnotetext{
${ }^{115}$ Cole, "Some Details," 9 ("foggiest," and "idiotic"), 13; Arthur Cole, "Business Manuscripts: A Pressing Problem," The Journal of Economic History, 5:1 (May 1945), 44-46; and Cole, "Evolution," 10 ("laying here and there").

${ }^{116}$ Quoted sections are from Cole, "Evolution," 10. See also List (1951), i; and Cole, "Some Details," 8.

${ }^{117}$ Quoted section is from Cole, "Some Details," 13. See also Cole, "Evolution," 10-11; and List (1951), i.
} 
of Baker Library's staff - a sudden loss of twenty people - and closed its manuscripts division for most intents and purposes. Although re-opened briefly around 1940, the division was closed during World War II and was not fully revived until 1947.

Regardless of staffing, additional manuscript materials continued to arrive at the Library, solicited and unsolicited, and a sizeable backlog of unprocessed manuscripts accumulated.

Yet much important work was accomplished even with reduced staffing. The core work of receiving and registering incoming acquisitions was maintained, basic cataloging of book and serial items continued, as did a basic level of reference and research support. Feiss and Margaret Ronzone, a graduate student from Radcliffe College, created standard deposit and gift documents, and also worked out a sequencing arrangement for records which allowed like items to be shelved together. This was an initial departure from the item-level approach taken by Eaton. ${ }^{118}$

Cole and Ronzone produced a seminal work on the arrangement and description of business records. First appearing as an article, "Business Manuscripts: Collection, Handling, Cataloging" in a 1938 issue of Library Quarterly, the work was subsequently revised and distributed in pamphlet form by Baker Library. It described a detailed and systematic process for the acquisition, selection, arrangement, description (relying on Cutter's Industries List), and physical treatment of business collections. "Business Manuscripts" drew upon Baker's work with records from New England textile firms and provided a "distinctive scheme" for organizing business manuscripts:"119

Under this scheme, the so-called administrative records come first, including minutes, where they exist and are available, stockholder records, and legal papers. Then follow the general accounting series, the ledgers, journals, and cash books. (Incidentally, although we have kept the cash books, I have not observed that many scholars have made use of them.) Next come the production records, and in the case of a large textile company these can be quite voluminous. A sub-section here would be the payrolls ... [t]hen follow the selling records; for textile companies, these often include dealing with a selling agent ... Finally there is a place for correspondence,

\footnotetext{
${ }^{118}$ For a sample of the forms, see Cole, "Business Manuscripts" (1938), 100, 102.

${ }^{119}$ Cole, "Business Manuscripts” (1938), 93-114; Altman, “A History” (1981), 181.
} 
and what may be called miscellany. In the mills organized on the Boston or Merrimack pattern, the treasurer was located in Boston, with the agent was responsible at the mill; letters between the two, where preserved, are of interest. Thus the thousand or more volumes of the typical large textile company collection fall into place. ${ }^{120}$

Cole promoted the 1938 publication as "the only manual of its sort in print" and wrote regularly that it was in "much demand."121

The article also outlined Cole's thoughts about the Baker Library collection as a whole, including the notion that there was an ideal collection of representative types of records which the Library should aspire to collect. Cole sought to build a finite collection with representative samples of records from each major industry (akin, perhaps to the "systematic collection" of objects attempted by some museum curators). Cole felt that some documents would "outlive their usefulness" and could be replaced by sets of records discovered subsequently which might provide better intellectual support for specific types of research. He felt that once a significant analysis was completed on longer runs of routine data - especially from bulky bound volumes - a repository could destroy the originals. ${ }^{122}$

The 1938 article also provided a platform for Cole's thoughts on the future of business archives in general. Acknowledging that no single institution could be a "national all-inclusive archives of business documents," he shared, publicly, Baker Library's intention to collect generally about pre-1890 New England business. Articles about the systems in operation at Baker and the 1932 List of Business Manuscripts not only helped the Library to formalize its internal procedures, they also shared its collections and innovative archival methods with a national audience. ${ }^{123}$

Cole developed a variety of networks to help acquire materials for Baker Library. Contrary to Charles Eaton's isolationist approach towards other campus libraries, Cole

\footnotetext{
${ }^{120}$ Lovett, "Business Records and Manuscripts" (1981), 22. A similar summary of Cole's system was also provided by Lovett in "The Appraisal of Older Business Records." The American Archivist, 15:3 (July 1952), 232.

${ }^{121}$ Cole, "The Baker Library as a National Research Institution," 2.

${ }^{122}$ Cole, "Business Manuscripts" (1938), 96.

${ }^{123}$ Quoted section is from Cole, "Business Manuscripts" (1938), 95. See also Bartoshesky, "Business Records," 481.
} 
determined to work collaboratively with the other Harvard librarians on both imprint and manuscript acquisitions. "[I] t was necessary to keep from being drowned," Cole wrote, "one did not have the privilege of trying to secure all the material in given fields." 124

Working with his staff, he developed a written "schedule" outlining the materials Baker Library would collect and, somewhat magnanimously, "those which we would allow Widener, the Law School Library, and other Cambridge and Boston library institutions to collect as they wished." Baker would not now collect works on labor, the poor, and socialism (covered by Widener), and he identified other topical areas to avoid duplication of effort, such as the drug trade (collected by the Harvard School of Pharmacy), employers' liability and workman's compensation (held by Harvard Law School Library), and planning (of interest to the Harvard Library on Landscape Gardening). Cole "staked out limits" for each library, so that Baker would be "leaning upon" these other libraries "for materials not highly important to the work of the Business School." The approach also acknowledged certain off-campus Boston library institutions, such as the Insurance Association of Boston, which collected materials on casualty and fire insurance, and the library of the Boston Street Railway Company for information about urban transportation. The schedule was shared with representatives at the other libraries where it "gained ready acceptance." 125

Individual members of the Business School faculty were another key group providing counsel for new acquisitions. Manuscripts curator Robert Lovett later reflected on his valuable consultations with faculty on new collections, including the sometimes contradictory advice (one might say "take payrolls above all else!" while another might say “we don't need payrolls!")· It was not simply a case of avocational interest for some faculty. In addition to the generalized Business School curriculum, Dean Donham sought to establish business history as a distinct academic discipline with its own tenured

\footnotetext{
${ }^{124}$ Cole, "Notes," 8, 12.

${ }^{125}$ While these decisions helped to focus collecting - particularly during the financial challenges of the Great Depression - some subsequent library staff considered Cole's actions as "unfortunate" to the overall collecting program at Baker Library, see Altman, "History" (1978), 74; Cole, "The Impact of a Large Collection," 188-89; Lovett, "Business Records and Manuscripts" (1981), 21; and Cole, "Notes," 11 (“...Widener, the Law School..."). For a detailed list of topics and libraries, see Cole, "Some Details," 22, which is also the source for quoted section "leaning upon."
} 
faculty. Norman Scott Brien ("N.S.B.") Gras was the first faculty member appointed to serve as the Straus Professor of Business History just as Baker Library opened. Gras groomed his own protégé, Henrietta Larson, to help build the emerging business history discipline. The two had met at the University of Minnesota where Gras encouraged Larson's study of the Minnesota wheat market - a topic which formed the core of her dissertation from Columbia University in 1926. When Gras moved to Harvard in 1927 to begin a program of research and teaching in business history, he invited Larson to join the new group. Working with other junior faculty, the two created a business history curriculum which was integrated into the primary Business School program. ${ }^{126}$

Gras, Larson, and former Business School Dean Edwin Gay helped to develop key publication outlets for the fledgling business history discipline and its emerging scholars. Gras and Gay were the leading founders and editors of the Journal of Economic and Business History. The group launched a monograph series, Harvard Studies in Business History, in 1931. It included works by K.W. Porter, Gras, Ralph Hower (a professor at the Harvard Business School and trustee of the Business Historical Society), and Larson's own work on Jay Cooke. Larson was also co-author with Gras of 1939's Casebook in American Business History which, alongside Gras' Business and Capitalism, became core texts for emerging courses in business history around the country. The two were approached by Standard Oil to author/edit a multivolume history of the company. ${ }^{127}$

The variety of new outlets for publication further heightened the profile of the Harvard School of Business, its faculty, and the holdings of Baker Library. Many of the monographs and many more article-length studies made close use of manuscript sources

\footnotetext{
126 “A Conversation with Robert Lovett," 19; Lovett, "Business Records and Manuscripts" (1981), 21; Biographical information on Larson is from Ralph Hidy and Muriel Hidy, "Henrietta Larson: An Appreciation," The Business History Review, 36:1 (Spring 1962), 1-10, and Bartoshesky, "Business Records," 479.

${ }^{127}$ Larson emerged as a significant scholar and editor in the field of business history, particularly through her fifteen years as editor of the Bulletin of the Business Historical Society, 1938-1953. Her 1949 Guide to Business History presented the first comprehensive bibliography for the discipline with more than 5,000 references, see Hidy and Hidy, "Henrietta Larson: An Appreciation," 7. See also N.S.B. Gras, "Past, Present, and Future of the Business Historical Society" Bulletin of the Business Historical Society, 24:1 (March 1950), 4; and "Memorial: Edwin Francis Gay," The American Economic Review, 37:3 (June 1947), 412.
} 
at Baker Library. Sweeping studies published by Gras such as his History of Agriculture in Europe and America (1925) and Industrial Evolution (1930) referenced dozens of Baker Library's smaller manuscript collections.

Unfortunately, the Business Historical Society was unable to sustain itself. As the field of business history matured, it became increasingly difficult to balance the varying needs of the historians, business professionals, academic scholars, and buffs who comprised the Society's membership. Tensions arose over differing approaches to business history. Membership dwindled after the World War II, and the Society folded in the 1950s. Most of the Society's assets were donated to the Business School, the Bulletin reemerged as the Business History Review, and all archival records previously "on deposit" from BHS were commuted into outright gifts. It is perhaps fitting that the final article in the closing issue of the Bulletin was a four-page description of a recentlyprocessed collection at Baker Library. ${ }^{128}$

The influx of records from BHS activities contributed to Cole's realization that a single, central, and national collection of business records was not tenable and led Baker to deaccession and transfer records to other repositories in appropriate states, as noted above. But encouraging other regional business records repositories was only a part of a grander scheme by BHS to ensure that materials were gathered more proactively across the country. Harvard business professor Ralph Hower developed a guide for understanding, selecting, and preserving business records. Simply entitled "The Preservation of Business Records," the guide was first published in 1937 as a special issue of the Bulletin of the Business Historical Society and then expanded into a standalone pamphlet in 1941. Arthur Cole considered this work a milestone in broadening understanding and discussion of the importance of business records. Hower's volume served as a good companion to "Business Manuscripts: Collection, Handling, Cataloging," the more process-oriented manual which Cole and Ronzone had produced in

\footnotetext{
${ }^{128}$ N.S.B. Gras, "Past, Present, and Future," 4-6; Altman, "History” (1978), 60; Lovett, "Business Records and Manuscripts" (1981), 21; Bartoshesky, "Business Records," 478; and Lovett, "Business Manuscripts in Baker Library: The Pierson Collection: Life in an Early Company Town," Bulletin of the Business Historical Society, 27:4 (December 1953), 260-264.
} 
1938. While Hower's publication was of great use to libraries and historical societies considering acquisition of business records, Cole felt it also presented "one of the most cogent and forceful arguments in favor of the creation of corporate archives" and hoped it would encourage individual firms to organize and retain their own records. ${ }^{129}$

Cole helped to launch the National Records Management Council in 1949. The hope was that by encouraging this work - including the "winnowing of the accumulated mass" of business records - that companies could retain their own records, at least "that portion that would be useful in the preparation of a history of the company." In 1961, Cole remarked that these efforts relieved Baker Library of a "considerable amount of anxiety" towards its perceived duty of the "retention and preservation of business records for the whole country." The Library and School would continue as a champion of corporate records management in the decades to come. ${ }^{130}$

Despite the limits Cole tried to place on record acquisition, Baker Library was always willing to consider "deposits" of material which might otherwise be lost. Some companies didn't desire to make an outright gift of their materials as their boards were reluctant to lose control of their materials. Cole acknowledged that deposits were very rarely withdrawn, but he felt it tied the hands of library staff in possibly replacing specific collections with others which might be more representative of a given theme or industry. Baker Library continued to allow for the "deposit" of records as a means to provide some initial preservation. Deposit agreements usually had a set date - often 20 years from the original date - after which the collections automatically became the property of the Library. ${ }^{131}$

This variety of networks - Harvard and Boston libraries, Business School faculty and alumni, the Business History Society, and scholars reading publications utilizing its

\footnotetext{
${ }^{129}$ Quoted section is from Bartoshesky, "Business Records," 481. See also Letter from Executive Secretary to Shaw Livermore, December 14, 1938, Business Historical Society Records, Harvard Business School, Carton 1, Folder "Business Historical Society - Acquisitions suggested 1929-1941," Ralph Hower, "The Preservation of Business Records," Bulletin of the Business Historical Society, 11:3/4 (November 1937), 37-61; and Ralph Hower, The Preservation of Business Records (Boston: Business Historical Society, 1941).

${ }^{130}$ Both quoted sections are from Cole, "Some Details," 11-12. See also Emmett Leahy, "Modern Records Management," The American Archivist, $12: 3$ (July 1949), 231-242; and Cole, "Evolution," 11.

${ }^{131}$ Arthur Cole, "Business Manuscripts" (1938), 99, and List (1951), iii.
} 
manuscripts - helped attract additional acquisitions to Cole and Baker Library. Although the rise of business history as a scholarly discipline encouraged many repositories to collect from their local areas, by 1956, Baker Library was acknowledged by most scholars as the premier business archives in the nation. ${ }^{132}$

The significance of the "Rapid Growth" period on Baker Library's manuscript collections is readily apparent through comparison of editions of the List of Business Manuscripts in Baker Library. Archival material more than doubled, from 508 collections in the 1932 edition to more than 1,100 discrete entries in the 1951 edition. Although the 1951 List may have been inflated by the inclusion of some grey literature from the imprint collections (and some items held by other Harvard Libraries), the overall increase in the size of Baker's manuscript holdings was still very significant. ${ }^{133}$

The central role of the Business History Society in this expansion has been mentioned above, as have the opportunities presented by the bankruptcy and closure of textile enterprises during the Great Depression. Yet the collections expanded in many other areas, too. This period saw important acquisitions in manufacturing industries, such as the records of the American Steel \& Wire Companies (30 linear feet, 1822-1936), business and sales catalogs from Reed \& Barton silversmiths (25 linear feet, 1828-1931), and the records of the Waltham Watch Company (111 linear feet, 1854-1941). Collections expanded in the construction, engineering, and railroad industries, including the Nashua \& Lowell Railroad (30 linear feet, 1835-1916) and the Boston \& Albany Railroad (66 linear feet, 1831-1898), which had been encouraged by the Railroad \& Locomotive History Society. There were also extensive additions in the shipping and "marketing services" industries, as well as the printing and publishing sector with the acquisition of records of the Boston Evening Transcript (54 linear feet, 1841-1941) and the business papers of Maine publisher and investor Edward Charles Allen (60 linear feet, 1871-1896).

\footnotetext{
132 Oliver W. Holmes, review of List of Business Manuscripts in Baker Library, by Robert W. Lovett, The American Archivist 15:2 (1952), 166-68; Oliver W. Holmes, "Some Reflections on Business Archives in the United States," The American Archivist, 17:4 (1954), 291-304; and Robert A. Shiff, "The Archivist's Role in Records Management," The American Archivist, 19:2 (1956), 111-20.

${ }^{133}$ List (1932).
} 
Ongoing relationships Baker Library maintained with some donors resulted in accruals to existing collections. A good example are the records of the wholesale marketing firm Nathan Trotter \& Company, which grew from 923 volumes to more than 1,300 volumes between 1932 and 1951 (and later grew to more than 1,400 volumes in its present form - 221 linear feet, 1798-1955). Similar additions occurred to the records of the textile shipper William Appleton (present collection 75 linear feet, 1831-1889) and also the Heard family of rum manufacturers and international traders (present collection 400 linear feet, 1734-1901). The latter grew through an "exchange with Yale University" in the 1940s, as well as an accrual from the Ipswich Historical Society in 1984. ${ }^{134}$

Cole was determined to maintain a focus on business and economic history. He had no interest in political and personal papers outside of this thematic scope and directed many non-business collections to other repositories. In some cases, such materials were separated and returned to donors, while Baker Library retained the business-related items they wanted. Cole was hesitant to collect materials on technology. When presented with a set of books and magazines from an executive at the New York Air Brake Company, Cole rejected them as "predominantly technological" and "largely inappropriate for the Baker Library."135

While Cole worked to focus Baker Library's manuscript acquisitions on New England, external influences (including the Business Historical Society) still allowed a certain number of "foreign collections" to enter the holdings. Included separately at the end of the 1951 List, these were predominantly smaller collections, often single items in the imprint collections from Britain, France, and Mexico. One exceptional collection were materials related to the business ventures of the famed Medici Family of Florence, Italy (15 linear feet, 1400-1600).

Along with the growth of the manuscript and imprint collections, other "subsidiary collections" emerged. Isolated stock certificates, charter parties, bills, and similar items were placed in a file of "Business Instruments." Clippings, advertisements, and circulars

\footnotetext{
${ }^{134}$ List (1978), 161.

${ }^{135}$ Arthur Cole, "Business Manuscripts" (1938), 98; and Cole, "Some Details," 20.
} 
were classified in accordance with the industry classification and placed in vertical files. "The photograph collection is extensive," indicated the preface to the 1951 List, "and included all framed pictures in possession of the School as recorded in the Manuscript Division. In addition, there is a large collection of industrial photographs, classified by industry number." Other materials, because of their format and need for special treatment, were grouped together as "Exhibits," including trade cards, paper money, and an abacus. ${ }^{136}$

Like the Corporate Records Collection, much of this material - particularly the biographical and photographic files - retained little provenance to donors and specific accessions. Additionally, there was the "museum" space that Eaton had allocated for the Railway \& Locomotive Historical Society for its display of railway paraphernalia. Although Eaton's intentions for three-dimensional objects were not clear, Cole was not sympathetic to the idea of collecting the "material of business" and generally turned down such offerings. These subsidiary collections were described through separate inventories, monographs, and special catalogs. Although omitted from the List, their formal existence reflected the growth and diversification of Baker Library's holdings during this active collecting period. ${ }^{137}$

While the collections were strongest in the textile and shipping interests of New England firms, by the time of Cole's retirement in 1956, Baker Library had firmly established itself as "practically the only sizeable collection of original business records in public or quasi-public hands," not only in the United States but, possibly, the world. Research use increased, particularly high volumes of research inquiries by mail from scholars, journalists, and people in business. "As one friend of the Library has phrased it," he wrote, "we have become a sort of Federal Reserve Bank among libraries - a librarians' library." 138

\footnotetext{
${ }^{136}$ List (1951), iv.

${ }^{137}$ Cole discusses his decision not to accept a large collection documenting the evolution of book printing in "Some Details," 18.

${ }^{138}$ Cole claimed that in a typical year, the Library received "something like a thousand reference inquiries by mail or telephone." This and the two quoted sections are from Cole, "The Baker Library as a National Research Institution," 2-3. See also List (1951), i.
} 


\section{Maturity and Stabilization, 1956-1980}

Manuscript acquisitions by Baker Library settled into a period of maturity and stabilization in the late 1950s, following the explosive growth in its collections during the 1920s and 1930s, and the resource and staffing shortages of the Great Depression and World War II. The overarching goals - and changing needs of faculty and students - of the Business School pushed Library priorities toward strengthening the book and imprint collection. Limited staff resources assigned to the manuscript collections directed energies toward reducing the unprocessed backlog, while slowing new manuscript acquisitions. ${ }^{139}$

The Library experienced transitions in its key personnel during this period. Overall staffing levels remained somewhat fixed, but professionally-trained librarians increased as a percentage. Arthur Cole became increasingly distant from operational control beginning in the 1940s, and three staff members played critical roles following Cole's retirement in 1956: librarians Donald Clark and Lawrence Kipp, and manuscripts curator Robert Lovett. ${ }^{140}$

Clark was the first trained librarian in a higher leadership role at Baker Library. He received a degree in library science from Columbia in 1936 and initially worked in libraries on the west coast. He was with the Economics Division of the New York Public Library when he was recruited to Baker. During his time at Baker, he remained actively engaged in professional service: he served a term as president of the Special Libraries Association (along with many other assignments in SLA), was on the editorial board of the Public Affairs Information Service, and edited a Harvard-produced monthly publication, The Executive, which selected and abstracted business books and periodicals, reaching more than 10,000 subscribers at its height in $1962 .{ }^{141}$

Cole hired Donald Clark in 1940 as an assistant librarian in the wake of Mary Feiss' dismissal. He was brought in to manage the operational aspects of Baker Library

\footnotetext{
139 Altman, "History" (1978), 78.

${ }^{140}$ Lovett, “Arthur Harrison Cole,” 87; and Altman, "History” (1978), 71, 91.

${ }^{141}$ Cole and Kipp, "Baker Loses a Helmsman," 20-22; and Altman, "History” (1978), 72.
} 
and was groomed as Cole's successor. Cole allowed Clark to slowly assume more control of the primary operations of the library, including staffing, new book acquisitions, the imprint collections, and most day-to-day management activities. Seeking to attract and retain qualified staff, Clark improved personnel policies and encouraged staff-suggested efficiencies, such as the relocation of the acquisitions staff nearer to the cataloging department. For student and faculty users, Clark converted a seldom-used staffed reading room into a "recreational reading room" for less-formal reading, study, and socialization. He also seated an art committee to help with the aesthetics of the physical space. ${ }^{142}$

Cole retained responsibility and oversight for "historical materials," such as older books, periodicals, corporation reports, and manuscripts. "Perhaps the Library benefitted from the presence of two differently trained, joint administrators," Arthur Cole reflected later. "It seems to me it has." In 1945, Clark and Cole undertook a review of the Library and its role in the Business School and found increasing interest in contemporary problems rather than historical ones. ${ }^{143}$

In 1948, as Cole developed and led Harvard's new Research Center for Entrepreneurial History, Clark assumed near-complete responsibility for the Library's administrative functions. Cole's work for the new Center proved awkward for Baker Library. Disagreements with N.S.B. Gras about the purpose of the Center and its appropriateness for the Business School drove Cole back to the main campus and the safe housing of the School of Economics. This continued confusion concerning the place of business history at Harvard pushed Cole further from the Business School and undermined his leadership of the Library. ${ }^{144}$

Before moving into the head librarian position, however, Clark faced opposition from those who still felt the head of Baker Library should have a firm education in business and economics. Regardless of his formal library training and professional experience, Clark was required by Dean Donham to complete the Harvard MBA program

\footnotetext{
${ }^{142}$ Cole and Kipp, "Baker Loses a Helmsman," 22; and Altman, "History" (1978), 78.

143 Quoted sections are from Cole, "Notes," 19. See also Cole and Kipp, "Baker Loses a Helmsman," 22; and Altman, "A History" (1981), 187.

144 Altman, "History” (1978), 77; and Altman, “A History” (1981), 187-188.
} 
(which he was happy to do at Harvard's expense). At the completion of his studies in 1949, he became associate librarian, and following Cole's retirement from Baker Library in 1956, Clark was named formally as head librarian (though Cole maintained various roles on the Harvard campus until his death in 1974). Clark remained with Baker Library until 1962 - a total of 22 years - when he departed to become head of the library at the University of California Santa Cruz. ${ }^{145}$

Lawrence Kipp, another professionally trained librarian, came from Harvard's Widener Library in 1954, initially as an assistant librarian under Arthur Cole. He, too, was groomed for advancement and was elevated to associate librarian following Cole's retirement in 1956 and eventually became head librarian in May 1963 following Clark's departure, ultimately retiring in $1978 .{ }^{146}$

More important to the maturity and stabilization period of manuscript collections at Baker Library, however, was the work of Robert Lovett. For most extents and purposes, Baker Library's manuscripts division had ceased operations during World War II. In 1948, Cole hired Lovett to re-establish the manuscript program, providing a small reading room and office/work area on the second floor of the Library. Although not formally trained as a librarian, Lovett was a New England native with a Harvard master's degree in history. Most importantly, he had archival experience working with the archives of Harvard College, a special undergraduate school within the larger University. Lovett later became curator of Baker Library's transportation collection, worked for the Medical Library archives, and helped to edit volumes reproducing documents from various Harvard collections. He was an active and engaged professional (which he considered to be a "strength rather than a weakness" for Baker Library), regularly presenting at historical and archival conferences, and he also served as chairman of the Business Records Committee of the Society of American Archivists. ${ }^{147}$

${ }^{145}$ Cole, "Evolution," 18; Altman, "History" (1978), 72; Altman, “A History" (1981), 188; and Cole and Kipp, "Baker Loses a Helmsman," 20, 22.

${ }^{146}$ Altman, "History" (1978), 79-81, 89-90; and Altman, “A History" (1981), 192-196.

147 Altman, "A History" (1981), 190; List (1951), i; Altman, "History" (1978), 66; Bartoshesky, "Business Records," 482; and Robert Lovett to Ken Carpenter, May 12, 1984, HBS Faculty Biography Files, Baker Library Harvard Business School (GB534). 
Lovett's task was to re-energize the manuscripts unit, particularly with regard to the backlog of unprocessed collections. Staff in previous periods had taken the easy route of focusing within collections on the bound financial accounting volumes. Lovett discovered that many collections, even some received as early as the 1920s, remained untouched in crates in a variety of storage areas. "Because of the Depression, and then the war," Lovett recalled later in his life, "many of these collections were not handled in any way ... When I arrived in 1948, one of my first jobs was to get all of the material out of storage, and start to process it." Lovett remained with Baker for 31 years, attaining the title of Curator of Manuscripts and Archives in 1961, working until his retirement in $1980 .{ }^{148}$

The Manuscripts Division became a lean but productive unit under Lovett's leadership. Initially described as a "largely one-man operation," the number of staff varied in later years, but rarely included more than Lovett, one other professional archivist, and a few part-time student assistants. Lovett particularly valued the central role that Eleanor Bishop played with arrangement and description as his full-time assistant from 1959 to 1975, including her as co-author of the 1969 and 1978 List publications. Despite staff size and limited resources, work completed with the collections during Lovett's tenure had a significant impact on their description and accessibility. ${ }^{149}$

Lovett and his staff had to give much of their initial energy to appraising, weeding, and processing manuscript material. Many of the collections had arrived at Baker Library with no formal appraisal and included many useless items. Lovett's experience working with archival collections at other Harvard libraries and his professional activity and reading, provided him with an understanding of "modern techniques" of archival practice. Though his writing doesn't specifically use the word

\footnotetext{
${ }^{148}$ Quoted section is from "A Conversation with Robert Lovett," 19. See also Lovett, "Business Records and Manuscripts" (1981), 22; Altman, "A History" (1981), 190; and Lovett, "Business Records and Manuscripts" (1981), 20.

${ }^{149}$ Robert Lovett, "Some Changes in the Handling of Business Records at Baker Library," The American Archivist, 19:1 (1956), 40; Lovett, "Business Records and Manuscripts" (1981), 21; Robert Lovett to Ken Carpenter, May 12, 1984, HBS Archives; Robert Lovett, "Business Manuscripts at Baker Library, 19691979,” The Business History Review, 53:3 (Autumn 1979), 386-391; and List (1969 and 1978).
} 
"provenance," he did plead with repositories and companies not to break up collections. Lovett used the phrase "original order" and stressed the need to organize and describe collections. He was realistic about the limits to which understaffed repositories can describe archives and manuscripts. "In most cases we cannot attempt to record piece by piece," he acknowledged, "the voluminous series of letters and documents precludes this." But Baker Library would at least provide a collection-level description and "list" the contents at the box, series, or folder level when possible. ${ }^{150}$

When Lovett arrived, nearly a fifth of the textile collections remained in storage, inadequately listed and difficult to use. Lovett devised an appraisal pilot project to better understand these records and determine what to keep and what to discard. Lovett documented the project in a 1952 article, "The Appraisal of Older Business Records," published in The American Archivist. Working with two graduate students from the departments of economics and history, Lovett reviewed three unprocessed textile collections. The team engaged Arthur Cole and other faculty to advise on the potential use of these records, both for company histories and for things such as "special studies of the history of business cycles, of long-range changes in productivity, or of changes in wage payments and earnings" (one of the grad students was using an analysis of payroll ledgers for his dissertation project). ${ }^{151}$

Lovett's pilot project codified the types of materials Baker Library would retain from most textile firm collections: General ledgers and journals, treasurers' records and other reports, as well as any correspondence which survived. Emphasis was given to the early years of a company's development. Lovett decided that routine materials, such as canceled checks, bills of lading, proxies, and express receipts, would be discarded. "Useful information could be obtained" from such records, Lovett wrote, "only at great expense" of time in lengthy analysis. Preference, he concluded, should be given instead to summary or periodic reports and, if a series was simply too large to keep, one might

\footnotetext{
150 Altman, “A History” (1981), 191. For insights on Lovett's knowledge of emerging archival theory and practice, see Lovett, "Some Changes," 39-44; Lovett, "Business Records in Libraries," 384; and Lovett, "Business Manuscripts," 348.

${ }^{151}$ Lovett, “The Appraisal of Older Business Records,” 232-233.
} 
sample records in some uniform manner over longer spans of time. Although Lovett was cautious ("destruction is very final") and claimed that the proportion of discards to what was kept was "not usually very great," the project discarded enough duplicative material to net the library a significant sum for the paper's scrap value. ${ }^{152}$

Interaction with the faculty, students, and other researchers provided important feedback to his work of appraisal and selection. "It was a small operation," Lovett recalled, "and we got to know our users very well." Not only did these interactions help Library staff in charting directions for their collecting work, but they created strong personal ties between staff and users: "I guess that was one of the things I liked most about the job," said Lovett, "the contacts with scholars who used Baker."153

The collection policy changed very little after 1951. Arthur Cole's decision to focus on pre-1890 New England materials made increasing sense, particularly as other repositories took more interest in business records. Limitations of space encouraged conservative selection, if not an excuse to turn down some material. "The stacks below are crowded and are not air-conditioned," Lovett noted. "Some collections are stored in a warehouse at the back of the [Harvard] Stadium, and delays of a day or two may be expected in access to this material." ${ }^{154}$

As Baker's collections matured, additional decisions limited collecting within thematic areas already well-covered by existing collections. By 1960, for instance, Baker Library had "sufficient" materials on farming and general stores. "One more single volume store ledger," Lovett noted, "doesn't tell much more than the ones [we] already have." 155

Purchasing materials outright, particularly single volumes, increased during this period. The 1978 List, for instance, identified nearly forty 'new' collections acquired by purchase. Lovett acknowledged the practice, claiming that although the bulk of materials generally came as gifts from firms or families, the Library did "on occasion purchase a

\footnotetext{
${ }^{152}$ Lovett, ibid., 233.

153 “A Conversation with Robert Lovett," 19.

${ }^{154}$ Altman, "A History" (1981), 191; List (1969), i; and Lovett, "Business Records and Manuscripts" (1981), 21.

${ }^{155}$ Lovett, "Business Manuscripts," 347.
} 
single volume or two of early date, say before 1820." Lovett indicated that some monetary arrangements were made for deposits of records from firms where Baker Library "has served in effect as the firm's archives." The Library was willing to put some restrictions on access to new acquisitions, but its goal was always to open records as soon as possible to researchers. ${ }^{156}$

Baker Library also removed or transferred several collections. The 1969 List specifies 16 collections either transferred to other repositories or returned to donors, while the 1978 edition listed 15 more. In some cases, Baker returned records previously placed on deposit to their original institutions, including the Maryland Historical Society, the Old Dartmouth Historical Society, and the Missouri Botanical Garden. Of note was the return of the Hancock papers to the New England Historic Genealogical Society after a deposit of nearly 40 years. Similarly, the First National Bank of Boston, which had deposited a variety of records during Arthur Cole's tenure, asked for their return when it decided to establish its own archives. ${ }^{157}$

As it had done in previous decades, Baker Library donated some non-New England collections to repositories in California, Oregon, Ohio, Kentucky, and New York. "We feel that if a collection relates wholly to another region ... we should send it there." Lovett referred to such transfers as a "shortcut to acquiring space," and some decisions were the result of the appraisal and processing work of Lovett and his staff. They saved time if they made disposal decisions before detailed processing and description. The preface to the 1969 List indicated that most materials selected for removal and transfer "had not been completely [described in previous editions of the List] and it seemed appropriate to transfer it before further work was done." Lovett also described a formal process by which Baker Library realized several thousand dollars in revenue by copying and selling some documents bearing postage and revenue stamps. ${ }^{158}$

156 Ibid., 347-348.

${ }^{157}$ List (1978), i-v.

${ }^{158}$ Quoted section is from Lovett, "Some Changes," 41. See also List (1969), iii; and Lovett, "Some Changes," 44. 
The removals were an indication of the collaborations Baker Library had created with other repositories, both locally and across the nation. Lovett found that relationship between New England's museums and archives of business-related documents and artifacts became less competitive and more cooperative over time. "As individual institutions have acquired "identities" in terms of acquisitions," he noted, "the other institutions have tried to be supportive, sometimes to the extent of transferring relevant holdings." This extended to one of Baker's key collection areas - the textile industry. Having established its core collection, Baker Library became more selective, acquiring just those few records that filled gaps in its existing holdings. Lovett referred duplicative textile materials to the Merrimack Valley Textile Museum in Andover, Massachusetts. ${ }^{159}$

It was a two-way street, and Baker Library received some significant new acquisitions from other academic institutions. One of its few new textile collections were the records of Suncook Mills (30 linear feet, 1864-1954), an outright gift from the University of New Hampshire. Yale University provided key materials, including a small collection of railroad research by its Professor Kent Healey (2 linear feet, 1931-1958) and records of textile mill supplier L.W. Carroll and Son (25 linear feet, 1839-1936). Yale also transferred two large and important collections on the metals industry in Waterbury, Connecticut: the Scovill Manufacturing Company Records (321 linear feet, 1790-1956) and the Smith and Griggs Manufacturing Company Records (111 linear feet, 18641939). ${ }^{160}$

Staff continued Cole's work in encouraging businesses firms to become more involved and more directly responsible for collecting and preserving their own records. This was partially a self-preservation activity against the potential flood of donations. Baker Library's long-standing policy of focusing on pre-1890 records had distinct spatial advantages. Cole was correct that "recent documents" were much more voluminous due to the advent of cost accounting and the emergence of machine document duplication and

\footnotetext{
159 “A Conversation with Robert Lovett,” 19.

${ }^{160}$ Lovett describes his trip to Yale to survey the Scovill records in "Adventures of a Business Records Hunter,” March 1985, HBS Faculty Publications Files, Baker Library, Harvard Business School (GB2.535). See also List (1978), i.
} 
production technologies. Even the shift from bound ledgers to loose-leaf notebooks and "vertical" files increased the challenge for records managers and archivists.

"Realistically, the records of a large modern company would swamp a facility like Baker," Lovett wrote in 1981. He worked on various initiatives, particularly with the Business Archives Committee of the Society of American Archivists, to encourage businesses to keep their own archives. ${ }^{161}$

Staff maintained and continued many traditional collecting networks. Although the Business Historical Society ceased operations, many of its former members continued to direct material to Baker. As alumni, Clark and Lovett interacted directly with many other Business School graduates who had moved into the business world. Lovett made regular trips to meet with donors and assess potential acquisitions, often accompanied by his wife on journeys into Maine, New Hampshire, and Vermont. ${ }^{162}$

The 1969 and 1978 lists of Manuscripts in Baker Library reflect the stabilization and maturity of the Library's manuscript collecting activity following 1951. Although nearly 20 years had elapsed between the 1951 and 1969 editions, growth of the manuscript collections had clearly slowed. Source information is inconsistent and fails to provide a single, total extent of the manuscript collections, but Table 2.1 provides an overview of collection growth. Assuming the Slater Mills records in 1916 were the first manuscripts acquired, these figures indicate that more than 2/3 of Baker Library's holdings were acquired during the repository's first 35 years - with indications that some of these were brought in after Arthur Cole joined the staff in 1929. Fewer than 350 collections were acquired in the repository's next 37 years (1951-1978), and Lovett noted that by 1978, only about a dozen collections were being added in an average year. ${ }^{163}$

\footnotetext{
${ }^{161}$ Quoted section is from "A Conversation with Robert Lovett," 19. Lovett mentions the changes from bound ledgers to loose leaf in "The Appraisal of Older Business Records," 238, while Cole is more detailed in "Business Manuscripts: A Pressing Problem," 44-46. See also Arthur Cole, "Business Manuscripts" (1938), 96-97; and JoAnne Yates, Control Through Communication: The Rise of System in American Management (Baltimore: Johns Hopkins University Press, 1989), 21-64.

162 "A Conversation with Robert Lovett," 19; and Lovett, "Adventures," 3.

${ }^{163}$ List (1969 and 1978). Some ship logs were aggregated in the early List publications, but separated as individual numbered entries in later editions. The preface to the 1969 edition also indicates that "certain family collections, which were scattered in different parts of the former List, have been brought together," List (1969), i.
} 
Table 2.1 - Growth of Collections, Baker Library, 1932-2017 164

\begin{tabular}{|c|l|r|r|r|r|}
\hline Date & \multicolumn{1}{|c|}{ Source of Information } & Number of & Cubic Ft. & \multicolumn{2}{|c|}{ Printed Guides } \\
\cline { 5 - 6 } & & Collections & & $\begin{array}{l}\text { Pages for } \\
\text { collection } \\
\text { entries }\end{array}$ & $\begin{array}{l}\text { Total Pages } \\
\text { incl. preface, } \\
\text { indices, etc. }\end{array}$ \\
\hline 1932 & List of Business Manuscripts & 508 & & 112 & $112^{*}$ \\
\hline 1951 & List of Business Manuscripts & 1,067 & & 174 & 213 \\
\hline 1969 & List of Business Manuscripts & 1,300 & & 245 & 334 \\
\hline 1978 & Manuscripts in Baker Library & 1,403 & & 261 & 382 \\
\hline 2017 & Baker Library Staff & 1,652 & 37,835 & & \\
\hline
\end{tabular}

* there was no index included in the 1932 Guide.

The pace of acquisitions after 1951 may also be inflated in some significant ways. As noted previously, later editions of the List included entries for rare and quasipublished documents from the imprint collections, as well as items held physically by other libraries on the Harvard campus. For instance, the Houghton Library held all 32 entries under the category for "Theatre" (half of which were 'new' to the 1969 edition). The Houghton Library also held a large number of the individual ships' log books included in the List publications. The Schlesinger Library at the Radcliffe Institute (the former Radcliffe College having merged with Harvard in 1963) held the records of the Lydia E. Pinkham Medicine Company (185 linear feet, 1776-1968), which were 'new' to the 1978 edition. ${ }^{165}$

One might question whether to 'count' the transfers of business collections from Yale, the University of New Hampshire, and other repositories in the same way as private donations or purchases. Some other 'new collections' weren't necessarily separate and discrete collections, either. For instance, the American Antiquarian Society assisted with the 1977 donation of materials from the Mixter family of Hardwick, Massachusetts. Although the Business Records of the Mixter and Knight Families (15 linear feet, 17931905) comprised the central part of the donation, 12 volumes in the collection pertained

\footnotetext{
${ }^{164}$ Figures are derived from the List publications (1932, 1951, 1969, and 1978). The 2017 figures are from Tim Mahoney, Special Collections Librarian, Baker Library, personal communication, September 6, 2017.

${ }^{165}$ Lovett, "Business Manuscripts," (1951), 259.
} 
to other firms. These were formed into 9 separate collections, each with its own entry in the List. Similarly, although the Superior Court of Cheshire County in Keene, New Hampshire, transferred the records of the bankrupt Cheshire Provident Institution for Savings (15 linear feet, 1833-1913), Baker archivists broke out the subsidiary records of 4 smaller predecessor banks as separately-listed collections. In light of these approaches to listing entries in the 1969 and 1978 inventories, the slowing of manuscript acquisitions during this period is even more evident. ${ }^{166}$

That said, Baker brought in many important collections during this period. Acquisitions to its core textile collection filled gaps in its existing holdings, expanded coverage through related industries, or, in some cases, added examples of textile enterprises outside of New England. In addition to the Suncook Mill records from the University of New Hampshire (mentioned above), Baker Library acquired the records of the Naumkeag Steam Cotton Manufacturing Company (45 linear feet, 1845-1947), the Merrimack Manufacturing Company (11 linear feet, 1821-1957), and the Faulkner and Colony Woolen Company of Keene, New Hampshire (42 linear feet, 1815-1948). The latter records were acquired after Arthur Cole was chided on a golf course by members of the Colony family for neglecting to mention the firm in his seminal study of the woolen industry; Cole immediately dispatched Lovett to collect the records. ${ }^{167}$

Historically, the success of the New England mill industry was based upon a number of subsidiary industries and infrastructures. After 1951, Baker Library acquired the business records of the Proprietors of Locks and Canals (13 linear feet, 1792-1947), which improved navigation and closely managed water power leases along the Merrimack River through Lowell and other textile towns. These acquisitions included the records of its engineer James Francis, and were complimented by a separate collection of papers from the firm's chief engineer, Arthur Safford (12 linear feet, 1903-1951).

Additionally, Baker Library expanded its textile interests beyond New England with the

\footnotetext{
166 The Cheshire records were re-integrated at a later date and now form a single collection at Baker Library. Lovett described his trip to Keene to survey the records in "Adventures of a Business Records Hunter," 8.

167 “A Conversation with Robert Lovett," 19; and Lovett, "Adventures of a Business Records Hunter," 5.
} 
acquisition of a large collection from the Bigelow-Sanford Carpet Company (28 linear feet, 1828-1953), as well as records relating to the Avondale Mills in Alabama (150 linear feet, 1923-1939) (though the latter were subsequently transferred to the public library in Birmingham, Alabama). ${ }^{168}$

Perhaps the single most important collection of business manuscripts acquired during this period were materials received in 1962 from Dun \& Bradstreet Company, a New York business services company specializing in gathering and reporting commercial data about other firms. Although a portion of the material comprised records of the operating firm itself (60 linear feet, 1831-1962, with additions in subsequent years), the more significant component was more than 2,500 bound credit report ledgers (249 linear feet, 1840-1895) containing information on literally thousands of American business firms. The correspondence files of Thomas Lamont (144 linear feet, 1894-1948) and Winthrop Aldrich (126 linear feet, 1918-1965, with additions in subsequent years) marked an important step in collecting national known bankers and financiers. ${ }^{169}$ Industry and manufacturing were strengthened with records of the Parker Mills and Tremont Nail Company (13 linear feet, 1845-1918) and the McLauthlin Elevator Company (10 linear feet, 1850-1912). New acquisitions in the rail industry included material relating to the bankruptcy and reorganization of the Florida East Coast Railway (7 linear feet, 1909-1955) and the transfer from Yale University of its collection from the New York, New Haven, and Hartford Railroad (69 linear feet, 1822-1964). Other larger acquisitions varied across the business world: the Walter Baker \& Company chocolate business (14 linear feet, 1812-1945), the Massachusetts Hospital Life Insurance Company (57 linear feet, 1823-1967), and the saddlery records of Smith-Worthington in Hartford (22 linear feet, 1818-1927).

After gaining a sense of completeness in its primary thematic collecting areas particularly textiles and manufacturing in New England in the period before 1890 -

\footnotetext{
${ }^{168}$ The extent of 150 linear feet is taken from the 1969 List publication. There is currently no record of a collection of this size and content at the Birmingham Public Library, though a smaller collection of Avondale records are preserved at Auburn University.

${ }^{169}$ Lovett, "Business Records and Manuscripts" (1981), 23; and List (1969), i.
} 
Baker Library cautiously expanded its collections into other areas, particularly emerging businesses and industries. Although still seeking collections with a "reasonable completeness ... for the life of the firm or activity to which they relate," the Library reached out into new sectors. Some of the new acquisitions contained only twentieth century material, defying Cole's long-standing policy focusing on pre-1890 business. For instance, Baker extended its holdings into the power and public utilities sector with the records of Eli Goldston, chief executive of Eastern Gas and Fuel Associates (7 linear feet, 1961-1974) and Earl Barber, a public utilities engineer in Massachusetts (11 linear feet, 1910-1969). The United States Justice Department, perhaps recognizing Baker Library as a center for information about business firms, donated a collection of photocopied documents it had gathered in pursuit of anti-trust cases concerning U.S. and foreign oil companies (9 linear feet, 1930-1952). ${ }^{170}$

Although none of these collections was large in comparison to Baker Library's textile holdings, together they represented a broadening of the library's collecting scope to more recently-created records. This loosening of the pre-1890 restriction allowed the Library to complement its Merrimack locks and canals records with predominantly twentieth century records, such as the personal papers of Arthur Safford, its chief engineer (12 linear feet, 1903-1942), as well as to acquire construction and engineering records from Stone \& Webster (27 linear feet, 1892-1956), and to even venture out of New England to collect mid-twentieth century labor relations materials from Thompson Products of Cleveland (27 linear feet, 1933-1964). The Library even accessioned a few small twentieth century collections pertaining to the automobile trade in New England carriage maker E.P. Bryant (1 linear foot, 1900-1915) and Briggs Motor Sales Company (4 linear feet, 1925-1945).

Baker Library even brought its historic commercial and mercantile collections into the twentieth century (regardless of Lovett's claim that additional store ledgers were not needed). It acquired a large collection of materials gathered by Harry Resseguie, an editor for Women's Wear Daily, about department stores along the eastern seaboard (44

\footnotetext{
${ }^{170}$ Lovett, "Business Manuscripts," 347.
} 
linear feet, 1945-1966). The business records of Louis Kirstein, owner of Boston's famed Filene's department store, included detailed information about his work with several national retail and merchandising associations (34 linear feet, 1909-1942). Smaller collections came in from Adler \& Childs of Dayton, Ohio (1.5 linear feet, 1933-1950) and Gimbel Brothers and Saks Fifth Avenue in New York (1 linear foot, 1939-1960).

The manuscripts unit became responsible for the Business School archives during this period, including pictorial records, maps, and exhibit materials. When Lovett arrived in 1948, the School Archives contained only a few copies of faculty publications, clippings files about the School and faculty, and such School records as "drifted into the library." Clark had appealed to alumni for materials, but Lovett systematized an approach to more comprehensively document the School's activities and scholarship. Lovett managed to gather records of the various Deans and librarians, as well as papers of prominent faculty. ${ }^{171}$

In addition to publishing its holdings through its own internally-published List guides, Baker Library began to list its manuscript collections with the National Union Catalog of Manuscript Collections (NUCMC) at the Library of Congress. This tool, initially issued through a series of print volumes starting in 1959, served as one of the first clearing houses for information about manuscript holdings around the nation. Lovett and Cole were also involved with a survey conducted by the Society of American Archivists of repositories, which encouraged them to list Baker's business holdings in NUCMC. ${ }^{172}$

Lovett observed that the combination of NUCMC, distribution of the List publications, and word of mouth across the scholarly community had an impact on use. In 1968-69, Baker Library recorded only 136 users; in 1977-78, it saw more than 250, with increasing numbers of researchers external to the Harvard community. The textile

\footnotetext{
${ }^{171}$ Lovett, "Business Manuscripts," 349; Altman, "History" (1978), 66; Lovett, "Business Manuscripts," (1951), 261; and Altman, "A History" (1981), 191.

${ }^{172}$ Cole, "Evolution," 11; and Lovett, "Business Records in Libraries," 253-261.
} 
collections remained a popular area for study, but the records of the Dun \& Bradstreet Company were in high demand as well. ${ }^{173}$

\section{Commentary and Conclusions}

The retirements of Lawrence Kipp in 1978 and Robert Lovett in 1980 provide a useful closure for this case study. Manuscript collecting had slowed by this time due to a variety of pressures including reduced staffing, a sense of completeness in core topical collecting areas, and a lack of storage space. Although Baker Library continued (and continues) to acquire new collections, its most valuable archival holdings had been acquired previous to 1980, particularly the period 1927-1956.

By 1980, Baker Library's collections had reached a level of maturity and some staff believed the Library could be more selective in what to acquire as it moved forward. Subsequent acquisitions were more likely to document emerging industries and new models of business activity, or come from firms active in later historical periods than those of its core collections. A few notable examples of manuscript collections acquired after 1980 would include records of the Polaroid Corporation (currently 857 linear feet, 1905-2005), early computer manufacturing firm Wang Laboratories, Inc. (155 linear feet, 1948-1992), and records of the investment banking firm Lehman Brothers (350 linear feet, 1868-2007), as well as other venture capital firms and entrepreneurs. Baker Library remains one of the pre-eminent archival repositories for materials in business and industrial history, but is also now one of many competitors for records of singular and significant firms and individuals from this genre. ${ }^{174}$

From its founding within an academic institution, the manuscript collections of Baker Library were primarily intended to support the educational and research needs of students, faculty, staff, and alumni of the Harvard Graduate School of Business. Thus, Baker's collections included a variety of resources to inform the curriculum, particularly the school's "case study" approach, and included print and manuscript sources, grey

\footnotetext{
${ }^{173}$ Lovett, "Business Manuscripts at Baker Library, 1969-1979," The Business History Review, 53:3 (Autumn 1979), 388-89.

${ }^{174}$ Altman, "History" (1978), 91; and Lovett, "Business Manuscripts," 347.
} 
literature, and even some three-dimensional artifacts. As the first repository to collect business materials - business having been considered neither a worthy academic discipline nor something that should be documented through historical records - Baker Library had no models to mimic. Because of its groundbreaking work, it became the model that inspired and informed repositories that later developed in other parts of the country. One subsequent commentator, archivist David Gilchrist at the Hagley Library and Museum, noted "a trip to Baker Library is a necessary part of the education of anyone interested in business manuscripts as much of the pioneering work in the field was done there." 175

Others, such as the industrial historians who developed the Smithsonian's Museum of History and Technology in the 1950s, would apply different appraisal schema to their acquisition of business and industrial records. Yet even these perspectives were influenced by the holdings at Baker Library. Robert Vogel of the Smithsonian noted:

Business records really were another category altogether with which we didn't do anything. That wasn't our role, at least as I saw our role. Our role was to record the history of engineering. Not business. It's a separate field, really ... And Baker is known as probably the best repository in the country for business records. There are others, of course, but in my limited experience, they are the best. ${ }^{176}$

Because its manuscripts were intended initially primarily for use within the Business School academic context, acquisition at Baker Library was driven toward specific types of materials. Baker Library researchers, at least initially, took the corporation and specific industries as their unit of study. These users encouraged collection of finance and accounting records, with only secondary interest in correspondence and other administrative records. Thus, Baker Library collected little engineering or shop practice information and turned away personal and political materials if they did not have direct

\footnotetext{
175 Gilchrist, "Report-1963," 1; Quoted section is from David Gilchrist to Richmond Williams, "Report of the Activities of the Specialist for the Period July 9, 1962, to December 31, 1962," 6-7, Box 169, Folder "Annual Reports-Library, 1960-1967," Eleutherian Mills Hagley Foundation Archives, Record Ground IV.

${ }^{176}$ Robert Vogel, personal interview, May 30, 2009.
} 
bearing on the core business topics desired by primary academic users at the Business School.

At first, staff believed Baker Library could collect at a national or even international scale. As the realities of just how much material was "laying here and there all over the nation" became known, staff quickly focused collections geographically on New England. Similarly, Baker's librarians decided to limit the collections to materials before 1890. Even with these foci, the Library encountered problems with space and staffing. As the collections matured, and as the School extended its education programs beyond the MBA, staff considered and acquired materials beyond these regional and temporal boundaries. As awareness grew of the richness of the collections, academic researchers external to the Harvard community became an increasingly significant component of Baker Library's user base. ${ }^{177}$

Although some of the line staff within Baker Library had either library training or experience in the technical operations of a library, for its first 50 years, the head librarians at Baker arrived with no formal library training. Key Harvard administrators believed that this new form of library - collecting imprints and manuscripts about business history - must be led by someone with an academic education in business. This approach produced mixed results during the tenure of Charles Eaton, but bore better fruit during the era of Arthur Cole. Formal library training and archival experience became increasingly important in hiring after 1940, and Baker Library emerged as a leader in emerging archival practice with business manuscripts. Lacking national archival standards for business records, staff had to address the specific challenges of organizing, classifying, and preserving such records. Baker Library's staff became increasingly professionalized in the 1950s and 1960s, and professional staff in its manuscripts unit became highly visible among both archivists and historians. ${ }^{178}$

Part of this visibility was the result of publications by the staff about their work. Distribution of the printed List of Business Manuscripts in Baker Library in 1932, 1951,

177 Cole, "Evolution," 10; and Copeland, And Mark an Era, 126-136.

${ }^{178}$ Bartoshesky, "Business Records," 482. 
1969, and 1978 played an important role in this, but Baker Library staff - and those working collaboratively with them in the Business School and the Business Historical Society - set themselves to a "definite publication effort" and produced seminal works on collecting and preserving business manuscripts. These efforts promoted the use of Baker's collections, but also alerted readers to the topical areas in which Baker Library was collecting. This, in turn, encouraged donors to consider supporting the enterprise with additional collections or with monetary support. By the 1970s, bibliographies on the care and handling of business manuscripts gave the work of Cole, Lovett, and Hower equal status to seminal works in the general field of archival administration by T.R. Schellenberg, Lester Cappon, and Lucille Kane. ${ }^{179}$

As has been shown, Baker acquired collections using a variety of networks and partner organizations. Harvard faculty and staff played significant roles in establishing networks; some, such as Arthur Cole, began their relationship as graduate students and continued in staff roles. The Business School relied on members of the business community to donate money (especially the significant gift from George Baker to construct the Business School campus), participate as instructors, host graduate students as interns, serve as objects of case studies, and also donate historical records. The larger network helping to direct manuscripts to Baker Library were alumni of the University and some were graduates of the Business School program.

Baker Library also developed collaborative relationships with other repositories. Some of these were academic institutions and larger historical societies with their own archival collections, while some were smaller agencies, public libraries, and even public records offices. As the institution's reputation as a collector of business records grew, many of these institutions transferred materials to the Library as the more suitable place for preservation. But as Baker Library's collections matured, and the institution faced

\footnotetext{
${ }^{179}$ List (1932); Cole, "Notes," 16; and Altman, "History" (1978), 77. Two examples of bibliographies are David Gilchrist's 1962 document, titled "Business Manuscripts - Select Bibliography," distributed by staff at the Hagley Library and Museum, Box 362, Folder "Collecting Policy," Eleutherian Mills Hagley Foundation, Record Group IV, and one included in Linda Vollmar, "Manuscripts Project Progress Report: The William Henry Collection," January 1969 (student paper submitted to Richmond Williams in connection with unnamed class H553, likely at the University of Delaware), 1, Box 373, Folder "Bibliography," Eleutherian Mills Hagley Foundation, Record Group IV.
} 
restrictions of space and staffing, it used these collaborations as a two-way street to deaccession and ship unwanted collections from Cambridge to other repositories around the country.

Relationships with a few professional societies developed into more detailed and symbiotic relationships which had direct impact on manuscript collecting. The collaboration that Charles Eaton established with the Railway \& Locomotive Historical Society took the Library in directions which proved discordant (particularly the collection of historical artifacts for exhibit and interpretation) and failed to deliver much in the form of manuscript referrals. But the longer relationship established with the Business Historical Society proved much more beneficial. Serving as the Society's official repository, Baker Library received thousands of linear feet of historical records from members or through their contacts across the country. Business historians and Baker staff used BHS publications, especially its Bulletin, as a vehicle to call for donations, announce new acquisitions, and showcase research in the collections.

Between 1908 and 1980, Baker Library amassed an amazing manuscript collection. Within its collecting area focus - New England before 1890 - it became the primary repository for records of some of the United States' key industries. The New England textile industry was central to the manuscript holdings, including not only highly significant records from primary milling firms, but also the records of ancillary firms and organizations. In addition, Baker Library's generalized collecting program encouraged the acquisition of more than 1,400 separate collections across all forms of business.

Baker faced increasing challenges due to the changing needs of its host institution. The initial interest by business history faculty in placing individual business enterprises at the center of their discipline didn't persist. Cole felt that studies of individual entrepreneurs and specific firms didn't "add up" to any significant understanding of the larger trends in business development. ${ }^{180}$

Cole also increasingly questioned the role and value of the manuscript collections, initially during the challenging budgetary periods of the Great Depression and World

${ }^{180}$ Cole, "The Impact of a Large Collection," 186. 
War II. At one point, he referred to the manuscripts program "as a marginal portion of the Library's domain," and noted that archival records were infrequently used by students. He was closely aware of the heavy staff costs involved in organizing, describing, and supporting use of such records, while also realizing that "the whole mass requires much storage space." 181

Over time, Cole discovered, manuscript items "were not necessary for the instruction of either students or the faculty in the prevailing case method" developed by the School. Eventually, it turned out, the collections were used almost completely by visiting scholars and PhD candidates external to the Harvard community. While Baker Library was making a significant contribution to the preservation of business records (and thereby, Cole claimed, "to American business and American civilization"), it became increasingly difficult to justify in terms of direct support for the curriculum of the School. Subsequent staff agreed that the pedagogical needs for historical records were now minimal. ${ }^{182}$

Defending Baker Library from the accusation of underutilization by students required increasing amounts of library staff time in later years. Writing in 1978, Baker librarian Elizabeth Altman commented that staff believed "many students leave the School with little knowledge of where to find literature on management and business information." She observed that student use of the collections (both print and manuscript) remained low and that as the use of the case method increased, demand on the library's collections declined. Altman noted a similar lack of use by faculty, suggesting at best a general indifference on their part to library matters, or at worst a lack of respect by Business School faculty for the Library staff or a more generalized sense of reduced status for the entire Business School by their counterparts "across the river." 183

Cole realized that the core needs of the Business School had drifted from Baker Library's primary focus. Fearing the discovery of this "drift," Staff worked diligently to

\footnotetext{
${ }^{181}$ Cole, "Some Details," 10 (... a marginal portion..."); Cole, "Notes," 14; Cole, "The Baker Library as a National Research Institution,” 3 (“... whole mass requires...”).

${ }^{182}$ Cole, "Notes," 7; Lovett, "A Brief Account," 2; Cole, "The Baker Library as a National Research Institution," 2; and Bartoshesky, "Business Records," 476.

${ }^{183}$ Altman, "History" (1978), 87-88.
} 
locate external funders to support the Library and external partners to whom a portion of the financial burden could be shifted. "The Baker Library has become a national research institution," Cole wrote in 1948, "and as such has a function that transcends provincial affiliations" such as the needs of a single institution's students. Although Cole was successful in locating support for specific projects and collections, he had mixed success attempting to fund endowments for book acquisitions, publication initiatives, and a standalone archival building. ${ }^{184}$

As use by the Business School community declined, staff observed a slow but steady increase in use by outside researchers. Increasingly, staff time was used to answer simple, ready-reference questions by phone or mail, to support the research of visiting scholars, and to assist external business users seeking everything from background on competitor firms in the Dunn Company records to "specific data of all sorts for use in corporate planning and consulting work." Of course, many external users simply wanted easy answers, not detailed research support. "Business manuscripts are not the most popular manuscript sources," Lovett wrote, "Their very bulk puts people off, for it takes much effort to pull out the nuggets - or the aggregates." 185

Although Baker Library's manuscript collections may not have continued to address original expectations for use, the Business school accepted that it was now charged to "deal with them" and that this responsibility, while costly, was a commitment they could not step back from. Regardless of these challenges - perhaps even ignoring, inspired by, or in spite of these challenges - Baker Library succeeded in preserving "an extraordinarily rich storehouse of knowledge regarding the past and present of business." Cole was correct in realizing that this storehouse would stand ready for a wide variety of researchers for an indeterminate time ahead. ${ }^{186}$

\footnotetext{
${ }^{184}$ Cole, "The Baker Library as a National Research Institution," 3.

185 Altman, "History" (1978), 82-84 ("specific data"); and Lovett, "Business Records and Manuscripts" (1981), 20.

${ }^{186}$ Cole, "The Baker Library as a National Research Institution," 6.
} 


\section{CHAPTER 3. FOUNDING AND EARLY DEVELOPMENT OF MANUSCRIPT COLLECTIONS AT HAGLEY LIBRARY AND MUSEUM, WILMINGTON, DELAWARE, 1953-1982}

\section{Introduction}

The Eleutherian Mills Historical Library (EMHL), commonly known as the Hagley Museum and Library in Wilmington, Delaware, or simply as "the Hagley," is one of the premier repositories of business records in the United States and has "played an important role in the history of technology for decades." Comprising more than 40,000 linear feet of records, the repository holds more than 2,700 manuscript collections, including the records of more than 1,000 business ventures, primarily located in the MidAtlantic region of the country. The repository works closely with the University of Delaware, whose Hagley Fellows program is considered one of the premier academic programs in the history of technology. ${ }^{187}$

Like Baker Library, the founding and early history of business and industrial manuscript collecting at Hagley can be examined in three primary phases: creation, rapid expansion, and maturity, although the Hagley's "creation" period was more complicated than that of Baker Library. At Hagley, it involved several units that had a separate institutional existence and had gathered materials for many decades. The complicated creation period for the Hagley ends only with the consolidation of these separate institutions in 1961 in a new purpose-built facility. Just as Baker Library experienced a period of rapid expansion after the accession of Arthur Cole, the new Eleutherian Mills Historical Library (EMHL), to use its official name before 1984, enjoyed a period of rapid expansion after consolidation lasting for around two decades. Around 1982, EMHL transitioned into a final period of "maturity" as expansion slowed.

\footnotetext{
187 Quoted section is from Glen Asher, "Researching the History of Technology at the Hagley Museum and Library," Technology and Culture, 44:4 (Oct. 2003), 762. Information on the extent of the collections provided through e-mail communication with Hagley Assistant Curator Chris Baer, July 25, 2017. See also Michael Nash, "Business History at the Hagley Museum,” Business History Review, 60:1 (Spring 1986), 104.
} 
This case study of manuscript collecting at Hagley draws from a variety of source material, both primary and secondary. Unlike Baker Library, a comparatively large amount of Hagley's internal administrative records, including collection policies, minutes of staff meetings, external correspondence, internal memoranda, and reports have been made available to researchers. Although the establishment and early development of manuscript collections at Hagley occurred later than at Baker Library (beginning at Baker in 1908 and in the 1950s at Hagley), the key participants in this early development have not survived to participate in oral interviews. Additional sources include articles and monographs published by Hagley archivists and administrators, including collection guides published in 1970 and 1978, and the finding aids published for its individual manuscript collections. ${ }^{188}$

\section{Creation of The Longwood Library and The Hagley Museum, 1953-1961}

The modern Hagley Library is the result of the consolidation of two established entities: the Longwood Library and the library of the Hagley Museum. The Longwood housed the personal papers of several generations of the du Pont family, collected over many generations and formalized as a "library" collection in the mid-1950s. The Hagley Museum's library at consolidation had the corporate records of E.I. du Pont de Nemours and Company (commonly referred to as the DuPont Company or simply DuPont). These records had been formalized into an internal archives during the development of a company historical museum, also in the mid-1950s. ${ }^{189}$

\footnotetext{
${ }^{188}$ Although some finding aids exist only as in-house printed collection inventories, many are posted to Hagley's online database (http://findingaids.hagley.org/xtf/), described in their online catalog (http://h92010.eos-intl.net/H92010/OPAC/Index.aspx) or shared to OCLC's ArchiveGrid online archival resource (https://beta.worldcat.org/archivegrid/). The published collection guides are John Riggs, $A$ Guide to the Manuscripts in the Eleutherian Mills Historical Library: Accessions through the Year 1965 (Greenville, Delaware: Eleutherian Mills Historical Library, 1970) and John Riggs, A Guide to Manuscripts in the Eleutherian Mills Historical Library: Supplement Containing Accessions for the Years 1966 through 1975 (Greenville, Delaware: Eleutherian Mills Historical Library, 1970), hereafter "Riggs, Guide (1970)" and "Riggs, Guide: Supplement (1978)."

${ }^{189}$ For ease of reference, I will use "du Pont" throughout this text to refer to the family name and "DuPont" for the corporation name, regardless of specific year. There are competing approaches to such references in other works. In his introduction to the 1970 collections guide, curator John Riggs acknowledges that
} 
Although not initially envisioned together, these collections merged to form the Hagley, a special research library devoted to industrial history, especially to "that part of industrial America which centers in the East, in the Delaware Valley." "The intent, in brief," one contemporary noted, was "to create a library and center of research and publication devoted to the industrial and business history of the region."190

\section{The Longwood Library}

The modern Hagley Library owes its existence in part to the multiple generations of the du Pont family who were responsible for founding and running a successful American explosives and chemical firm: E. I. du Pont des Nemours and Company, founded in 1802. Pierre S. du Pont (hereafter P.S. du Pont) was of particular importance. He rose to leadership in the DuPont Company, serving on the corporate board from 1902 to 1940 and as chairman from 1919 to 1940 . He transferred his success as a corporate manager to General Motors, where he served as board member (1913-1944), chair, and president. By 1924, however, he had stepped back from direct involvement in the day-today management of both companies. ${ }^{191}$

P. S. du Pont's wealth and avocational interest in horticulture led him to create Longwood Gardens on an estate he purchased near Kennett Square, Pennsylvania, thirty

the spelling of the surname has varied over the centuries and that Hagley indexers endeavored to locate and use what was appropriate for each family member during their era. In later years, Hagley staff tended more toward spelling the du Pont family name with a lower case "d," and the DuPont Company with an upper case D, no space, and an upper case P. See Nash, "Business History at the Hagley Museum," 105, note 1.

190 Charles David, “The Longwood Library Program as Presently Conceived,” December 16, 1955, 5, Box 166, Eleutherian Mills Hagley Foundation Archives, Longwood Library , Record Group IV, (hereafter EMHFA/RG4); "Notes for a talk to the Wilmington Garden Club 6 January 1958," Unknown author (likely Charles David), 7, Box 159, Folder "Miscellaneous Subjects," EMHFA/RG4; and Charles David, "Longwood Library Progress Report," April 30, 1956, 1, Box 145, Folder “Annual Reports 1955-1960," EMHFA/RG4.

191 The best biographical studies are Alfred Chandler and Stephen Salsbury, Pierre S. Du Pont and the Making of the Modern Corporation (New York: Harper \& Row, 1971) and sections of William S. Dutton, Du Pont: One Hundred and Forty Years (New York: Scribner, 1951). A useful chronology is included in Riggs, Guide (1970), 106-114. To mark his May 1924 departure from direct management, P.S. du Pont established a holding company for his stock interests to provide an annuity of $\$ 900,000$ a year until the deaths of both he and his wife. He retired as chairman of the DuPont Board of Directors in May 1940. 
miles northwest of the DuPont Company headquarters. In 1946, he created the Longwood Foundation, a non-profit educational corporation, and funded a substantial endowment that helped propel the gardens to international prominence. He restored and enlarged the estate's eighteenth-century residence at Longwood into a country home to which he could escape from the business pressures of Wilmington. It was within this building that he gathered books, personal papers, and other materials relating to his life and those of his du Pont forebears. These included the historical records of Pierre Samuel du Pont de Nemours, a French economist, reformer, and statesman, and his sons, particularly Eleuthere Irenee du Pont de Nemours (hereafter E.I. du Pont), a scientist and entrepreneur, who had studied the manufacture of explosives and gunpowder with Antoine Lavoisier at the French Arsenal. ${ }^{192}$

In October 1799, amidst the storm clouds of the French Revolution, the family immigrated to the United States, transporting a sizeable collection of books and personal papers. This collection passed through successive generations with personal and commercial materials added, including correspondence with French intellectuals and economists such as Francois Quesnay and Anne Robert Jacques Turgot and American statesmen including Thomas Jefferson and Benjamin Franklin. As the family's enterprises and wealth grew, so did their appreciation for their own historical records. Some envisioned the possibility of a standalone structure to gather the family papers and books "scattered in all our houses."193

192 Chandler and Salsbury, Pierre S. Du Pont, 587-589; Riggs, Guide (1970), 107; Charles David, "Third Annual Report," November 11, 1958, 3; Dumas Malon, ed., Correspondence Between Thomas Jefferson and Pierre Samuel du Pont de Nemours, 1798-1817(New York: De Capo Press, 1930), xii; Charles David, "The Longwood Library," Papers of the Bibliographic Society of America, 51:3, (1957), 185; Eleutherian Mills Historical Library, "Handbook for Guides," Fall 1961, 3, Box 149, Folder "Guides, Handbook for," EMHFA/RG4; Riggs, Guide (1970), 684; and The History of the E.I. du Pont de Nemours Powder Company: A Century of Success (New York: The Banker and Investor Magazine Publishing Company, 1912), 22, 29.

${ }^{193}$ Quoted section is from Eleutherian Mills Historical Library, Eleutherian Mills Historical Library; A Record of Its Dedication on 7 October 1961 (Greenville: Eleutherian Mills-Hagley Foundation, 1961), 5. See also Eleutherian Mills-Hagley Foundation, The Hagley Museum: A Chronicle of America's Industrial Heritage (Greenville: Delaware, Eleutherian Mills-Hagley Foundation, 1963), 20-23 and 35; Nash, "Business History at the Hagley Museum," 106; Roxanne Therese Johnson, An Analysis of the Early Record Keeping in the Du Pont Company, 1800-1818 (New York: Garland, 1989), 6; Riggs, Guide (1970), xi-xiii; Linda Heineman, "Eleutherian Mills Historical Library, Greenville, Wilmington, Delaware," unpublished student paper for LS 535 (unknown institution), May 1971, 1, Box 363, Folder 
Yet it would take many decades before P.S. du Pont saw the concept through to conclusion. By 1914, he had completed significant work on the gardens and remodeled the mansion, including a purpose-built addition to house the growing collection of family manuscripts. Carpenters constructed a "library vault" under the reception room of the house in 1924, and in 1948, du Pont converted a bowling alley into additional storage. Following professional advice, he purchased library shelving and archival manuscript containers for this air-conditioned storage area. Additional records were stored in a detached garage on the Longwood grounds. ${ }^{194}$

With the goal of making the materials accessible to scholars, P.S. du Pont decided to use the Longwood mansion itself as the physical structure for a "library of a public nature" where "graduate or research students and other users would be properly serviced." On December 14, 1953, the State of Delaware issued a certificate of incorporation for the Longwood Library Association, to establish "a free, public, and nonsectarian library for the use of the public and for the purposes of instruction and education." 195

Lammot du Pont Copeland was elected president of the association. He and fellow board member Henry B. du Pont - both nephews of P.S. du Pont - led much of the

"History of Eleutherian Mills Historical Library," Eleutherian Mills Hagley Foundation Archives, Library, Record Group V, (hereafter EMHFA/RG5); and Jim Parks, "A Sense of Corporate History: Hagley Museum and Library is the Nation's Foremost Depository of Corporation Archives," Focus: Metropolitan Philadelphia's Business Newsweekly (July 19, 1989), 19.

${ }^{194}$ Chandler and Salsbury, Pierre S. Du Pont, 312-313; "Handbook for Guides," 1961, 3; Walter Heacock and Charles David, "Proposed Revision to a Document dated 12 December 1956," February 24, 1958, 3 5, Box 154, Folder "Proposal for a New Joint (Hagley-Longwood) Library Building," EMHFA/RG4; P.S. du Pont to Pepper, Bodine, Stokes \& Hamilton, January 6, 1950, Box 330, Folder "Preliminary Planning of Library, 1946-1957," EMHFA/RG4; Frank Battan, "Narrative on Development of the Longwood Library Under the Late Pierre S. du Pont," January 16, 1959, 1, Box 145, Folder "Annual Reports 1955-1960," EMHFA/RG4; David, "Notes for a talk to the Wilmington Garden Club," 4; and Thomas Butler, "Narrative on Development of Longwood Library Association," December 21, 1955, 1, Box 330, Folder "Preliminary Planning of Library, 1946-1957," EMHFA/RG4.

${ }^{195}$ Quoted sections are from Battan, "Narrative on Development of the Longwood Library," 1-4. Always the shrewd businessman, P.S. du Pont was careful to obtain tax-exempt status for the Association to enhance the impact of his planned donation of the house and surrounding property to the venture, see Butler, "Narrative," 1955, 7; Charles David, "The Longwood Library, Kennett Square, Pennsylvania," Bulletin of the Special Libraries Council of Philadelphia and Vicinity, $22: 3$ (January 1956), 1, 34; Heacock and David, "Proposed Revision," 1958, 5-6; and Butler, "Narrative," 1955, 5. See additional communications and corporation papers in Box 330, EMHFA/RG4. 
work to develop the Longwood Library. Another key figure was Frank Battan, personal secretary and close friend to P.S du Pont. Battan was elected board secretary and shepherded the library project along, developing initial estimates of annual library operating costs and structuring transfers of General Motors Corporation and United States Rubber Company stock from P.S. du Pont's personal portfolio to endow the enterprise. Many later acknowledged the Library would never have been "born" without Battan's efforts. ${ }^{196}$

Sadly, P.S. du Pont did not live to see the library through to completion. His death on April 5, 1954, complicated matters because he had failed to finalize codicils to his will that would have transferred the mansion house, fifty acres of the surrounding property, and the intended stock bequests. Battan worked tirelessly with the family and Longwood Foundation board to see that P.S. du Pont's intentions were honored. He also convinced the trustees not to name the library in P.S. du Pont's honor. " $[\mathrm{H}] \mathrm{e}$ had a very strong feeling that any public institution, association or function that is used by the general public should not be connected with a particular name of a family."197

Unlike Baker Library, the Longwood Foundation hired an experienced library administrator to lead the fledgling institution. Dr. Charles David, the first Director of the Longwood Library, was hired in 1955. Although not a librarian by initial training, he brought a wealth of experience in historical research, scholarship, and academic library administration to the new venture. While attending Northwestern University, he received a Rhodes scholarship to complete his undergraduate studies in modern British History at Hertford College, Oxford. He continued into graduate studies at the University of Wisconsin, where he completed a master's thesis in French history, then went to Harvard, where he completed PhD in 1918 with a dissertation concerning Robert Curthose, eldest

\footnotetext{
${ }^{196}$ Richmond Williams, "The Longwood Achievement," in John Riggs, editor, Charles Wendell David: Scholar, Teacher, Librarian (Philadelphia: Union Library Catalog of the Philadelphia Metropolitan Area, 1965), 46, 48; Battan, "Narrative on Development of the Longwood Library," 4; J.B. Riggs to Richmond Williams, "Critique on Draft of History of the Library," June 21, 1973, 1, Box 363, Folder "History of Eleutherian Mills Historical Library," EMHFA/RG5. Unfortunately, Battan's health suffered during his years with Longwood, and he eventually retired due to illness in 1963, see Richmond Williams, "1963 Report,” 8, Box 169, Folder “Annual Reports-Library, 1960-1967,” EMHFA/RG5.

${ }^{197}$ Butler, "Narrative," 1955, 11; and Battan, "Narrative on Development of the Longwood Library," 6.
} 
son of William the Conqueror. He received recognition as an emerging medieval scholar and accepted an appointment as associate professor at Bryn Mawr College, where he worked for more than 25 years. ${ }^{198}$

As a historian, Charles David had an abiding interest in libraries and the work they did to collect and catalog information for scholars. In 1933, he helped establish the Union Library Catalogue of the Philadelphia Metropolitan Area, which used Works Progress Administration monies to microfilm the catalogs of more than 100 libraries in the Philadelphia area and produce a single, comprehensive, card catalog. The project also provided initial funding for staff to service the catalog - and to respond to telephone inquiries from member libraries concerning the location of specific resources. ${ }^{199}$

The catalog project introduced Charles David to the executive leadership of the University of Pennsylvania, whose library system was outdated and in need of improvement. Not only did the University administration agree to house the new union catalog on its campus, but they also invited David in 1941 to assist them in a review of their library system. Hired as Director of Libraries, he oversaw a transformation of the Penn library system and its physical infrastructure. He also expanded research and scholarship programs at the new library, mounting international exhibits and hosting academic symposia. ${ }^{200}$

Charles David became executive secretary of the Association of Research Libraries from 1947-1962 and served as chair of the board for the American Library Association. In an era before photocopying, David was a leader in the use of microfilming as a means of preservation and distribution, working through such organizations as the American Documentation Institute and the International Federation of Documentation. ${ }^{201}$

${ }^{198}$ Charles David, "Robert Curthose, A Critical Biography" (unpublished dissertation, Harvard University, 1918). Information about David's early life, education, and career before Hagley can be found in Caroline Robbins, "The First Half Century," in Riggs, editor, Charles Wendell David, 10-18.

${ }^{199}$ Eleanor Campion, "The Union Library Catalogue," in Riggs, editor, Charles Wendell David, 19-24.

200 John Lewis, "Introduction," in Riggs, editor, Charles Wendell David, 7-8.

${ }^{201}$ Rudolph Hirsch and Margaret Nolan, "The Peaceful Revolution," and Verner Clapp, "Bibliographic Vision," both in Riggs, editor, Charles Wendell David. 
Following his retirement from the University of Pennsylvania in 1955, Charles David was selected as founding director of the Longwood Library. Arriving at Kennett Square, Pennsylvania, he discovered that little of the "necessary work of organizing it into an effective manageable library and archive" had been done and there was no "adequate catalog or record." In addition to the backlogs of unprocessed du Pont family books and manuscripts, there was "a reference collection to create, a staff to assemble, the specific institutional directions to chart, and the physical problems of converting a residence into a library building to solve." Thanks to the transfer of stock from P. S. du Pont's estate, however, the operating budget was not insignificant for the mid-1950s. Once fully staffed, the Longwood Library was spending \$230,000 to \$350,000 annually, which included a generous acquisitions budget for book and imprint purchases. ${ }^{202}$

Charles David set out immediately to identify and hire competent catalogers for the book collection and an experienced manuscripts specialist to undertake a similar work with the manuscript collection. By the autumn of 1956, five departments were in operation. Organizational charts from the early years document a staff of 25, with David as director and Frank Battan serving as assistant director and business manager. The acquisitions department was led by Grace Ottey, who brought experience from the Lippincott Library at the University of Pennsylvania's Wharton School of Business. Earle Coleman headed the cataloging department, which included Evald Rink, who brought experience dealing with business publications. Frank Battan led the research and translation department (many of the early du Pont family papers were in French), which

\footnotetext{
${ }^{202}$ Quoted section about "adequate record" is from Charles David to Board of Directors, Longwood Foundation, September 30, 1955, 1, Box 145, Folder "Annual Reports 1955-1960," EMHFA/RG4. Quoted section about "converting a residence" is from Richmond Williams, "Preliminary Draft" history of library, June 16, 1973, 3, Box 363, Folder "History of Eleutherian Mills Historical Library," EMHFA/RG5. In 1959 and 1960 the total operating budget was $\$ 230,000$, growing to $\$ 358,000$ in 1964, and $\$ 381,500$ in 1966. By 1982 the museum budget was $\$ 2.7$ million a year, with $75 \%$ of its operating budget from the foundation endowment, which was valued at \$27.4 million, see Charles David, "Fourth Annual Report," November 10, 1959, 14, and Charles David, "Fifth Annual Report," October 1960, 14, both in Box 145, Folder "Annual Reports 1955-1960," EMHFA/RG4, as well as Tracey Linton Craig, "Delicate Balance: Hagley Museum Traces the Impact of Technology and Its Products on Society and the Individual," History News,37:5 (May 1982), 21. David, "The Longwood Library," 1957, 199; and Richmond Williams, “1964 Report,” 6, Box 169, Folder “Annual Reports-Library, 1960-1967,” EMHFA/RG5,
} 
later assumed all reference functions as well. Additional maintenance and photographic functions were managed by specific individuals; photographic duplication provided the only means of duplication in the era before photocopy machines came into general use. ${ }^{203}$

Perhaps the most critical operational unit was the manuscripts department, as it would bear the important initial burden of arranging and describing the du Pont family papers. Charles David found hiring a manuscripts curator the most difficult staff problem of all, and eventually settled on Dr. John Beverley Riggs, who began work in September 1956. Riggs' previous work experience included positions at Mt. Vernon and the Manuscripts Division of the Library of Congress. His doctoral research at Yale University involved a survey of foreign archival sources for the study of American business and economic history, which seemed a good fit for the work at hand. ${ }^{204}$

Like Baker Library during its earliest decades, David and his staff had to create all of the necessary policies and procedures for the new manuscript collection. Riggs implemented a system following the prevailing, item-level, historical manuscripts approach he had encountered at Mt. Vernon and the Library of Congress. It began with a structured accessioning system utilizing donor forms and case files to closely document each donation, record the provenance of the collections, and track any restrictions on the use of specific materials. Although a slow and meticulous process, staff had processed more than 380 separate accessions by the end of $1962 .{ }^{205}$

\footnotetext{
${ }^{203}$ Grace Ottey managed the acquisitions department for 21 years, dealing primarily with purchasing imprints, but also managing incoming manuscripts acquisitions, see David, "Longwood Library Progress Report," 1956, 1; David [1955 Report], 1; Charles David, [First Annual Report], September 17, 1956, 8, Box 145, Folder "Annual Reports 1955-1960," EMHFA/RG4; "The Reference and Research Department," undated (ca. 1962), Box 296, Folder “Annual Reports, 1956-1963," EMHFA/RG5; "Organizational Chart," October 29, 1958, Box 162, Folder "Personnel Chart," EMHFA/RG4; and "Organizational Chart," July 15, 1959, Box 151, Folder "Longwood Library Organizational Chart 1959," EMHFA/RG4.

${ }^{204}$ David, "Longwood Library Progress Report," 1956; David, "Brief Progress Report for the Period October 1-December 31, 1956,” January 24, 1957, Box 145, Folder “Annual Reports 1955-1960,” EMHFA/RG4; and David, "The Longwood Library,” 1957, 200.

${ }^{205}$ Charles W. David, "Second Annual Report," September 30, 1957, 6, Box 145, Folder "Annual Reports 1955-1960," EMHFA/RG4; Walter Heacock, "The Foundation Policy for the Acquisition and Administration of Historical Materials," February 4, 1972, Box 373, Folder "Acquisition Policy," EMHFA/RG5; Richmond Williams, "1962 Report," 6, Box 169, Folder "Annual Reports-Library, 19601967," EMHFA/RG5; and John Riggs, "1963 Report of the Department of Manuscripts," 3, Box 365, Folder “Annual Reports, 1956-1986,” EMHFA/RG5.
} 
Within the collections, the task of arranging and describing the extant du Pont family manuscript material was daunting. Before Riggs' arrival, Charles David had temporary employees opening envelopes and filing manuscripts in rag paper folders in chronological order. Stored in cardboard boxes, the records were shelved in the stacks area, following their initial inventory arrangement. ${ }^{206}$

Riggs implemented a systematic and detailed approach to the processing of manuscript collections similar to that of the accessions and case files - and with the ultimate goal of an item-level catalog for all materials. He outlined three stages of work. Inventorying would allow staff to identify and locate materials across the sprawling collection. A second stage of integration involved shifting, sorting, and dating arranged papers to produce a logical and recognized order. ${ }^{207}$

Once inventorying and integration are completed, the final task of cataloguing individual items will begin. A card file, arranged alphabetically and listing each item, is our goal. All documents will be numbered, and this will give to each item its proper designation for referencing within the collection as in all published citations. Eventually, when the catalogue is finished, it is our intention to reproduce the cards for two additional files, one to be arranged chronologically and the other by subjects. The subject catalogue, while difficult to form, will be based on brief descriptive entries set down in the initial steps of cataloguing. ${ }^{208}$

Minutes from meetings of the Longwood staff reflect the benefits and challenges of this level of "individual cataloging" of manuscript collections. The approach required staff who were more expert at typing and transcribing than analytic or intellectual work. "[W]orking with manuscripts is one of the most tedious and time consuming things ever done in a library," noted Riggs. "There must be a consistent standard and the work must be done in uniform order." In seeking to replace an assistant in the manuscripts

\footnotetext{
${ }^{206}$ David, [First Annual Report], 1956, 8; and "Handbook for Guides," 1961, 12-13.

${ }^{207}$ David, "The Longwood Library," 1957, 200.

${ }^{208}$ David, "Notes for a talk to the Wilmington Garden Club 6 January 1958," 1.
} 
department, for example, the staff agreed that "a competent typist hired on a temporary basis would fill the requirement" rather than a trained librarian. ${ }^{209}$

During the first two years, the Library was not generally open to public, although some scholars were allowed special access for research deemed important and/or time sensitive. Lacking a reading room, the Library moved such researchers from office to office as spaces became available in the Longwood residence. Word spread about the new venture, but the lack of control was of concern for Longwood staff. "We only ask the indulgence of prospective researchers," pleaded Charles David, "we can hardly find ourselves in a position to give more than limited access until cataloguing is well advanced."210

As the flagship collection at the Longwood Library - and the direct link to the endowment funding from the family -processing the du Pont family papers was of immediate importance. It was a complicated set of materials, too, with more than eight separate groupings representing the different branches of the family. The largest block of papers were those amassed by P.S. du Pont, commonly referred to as the "Longwood Manuscripts" (1,065 linear feet, 1438-1954) because they were gathered in the Longwood Mansion location. A second significant collection was acquired from Henry Francis du Pont and were known as the "Winterthur Manuscripts" (156 linear feet, 15881955) for their location at his estate in nearby Winterthur, Delaware. Although provenance required the two collections to remain separate and distinct, there was a great deal of crossover of correspondents, content, and document types between them. The combined accessions included records of more than five generations. ${ }^{211}$

\footnotetext{
209 “Minutes," Longwood Library staff meeting, January 15, 1957, 2-3; unless otherwise noted, minutes from staff meetings under Charles David's direction during the period 1957-1961 are preserved in Box 156, Folder "Staff Meetings: Minutes 1956-1961,” EMHFA/RG4.

${ }^{210}$ Quoted section is from David, "The Longwood Library," 1957, 201. See also "The Reference and Research Department," ca. 1962, 1.

${ }^{211}$ The work of organizing and describing the P.S. du Pont papers proved more than first expected. Sometime during 1960, staff made the "disconcerting discovery" of a "considerable quantity of P.S. du Pont papers" in an outbuilding they had not originally surveyed. See David, "Fifth Annual Report," 1960, 4. Because of the gathering interest in the centenary of the Civil War, Longwood staff created an arbitrary chronological break in the manuscript collections at the year 1865, which marked the end of hostilities as well as the death of Admiral Samuel Francis du Pont. Longwood staff would devote its immediate processing efforts to the earlier period to get that material into shape for use by scholars - and
} 
At the other end of the spectrum, the extant materials at Longwood also included the more recent papers of P.S. du Pont (1,000 linear feet, 1880-1954). Longwood staff cataloged some of this material immediately, creating a 20,000-card index and a typed inventory more than 700 pages long. Frank Battan worked with the more confidential parts of the papers and hired Ruthanne Hindes, an "experienced archivist," to work on the collection. Records of the period do not disclose any cleansing of potentially unsavory or controversial materials, but the P.S. du Pont materials were segregated from other collections in a locked cage in the stacks area. ${ }^{212}$

A large group of the du Pont family - who also populated the Foundation board and represented significant shareholders in the DuPont Company - were surprisingly actively involved in the Longwood project. They felt that the materials were "their collections," wanted to give advice on aspects of family history, and often donated "new material," regardless of its compatibility to the collecting philosophy developing at Longwood. Charles David considered implementing a policy to allow Longwood to reject or dispose of family offerings not germane to the collections. Staff were concerned, however, that such a policy would cause ill feelings, and the library might actually miss opportunities to receive important additional documents and books. David was "willing to be a receiver so long as he is not required to be a foolish keeper."213

\section{The Hagley Museum and the Records of the DuPont Corporation}

Separately from the Longwood Library, the Hagley Museum gathered a significant collection of manuscript business records of the DuPont Company. The development of this archival collection dates to the company's early interest in its own

to prioritize publication of an edited volume of the Admiral du Pont correspondence in 1960 in advance of the centennial observations, see David, "Brief Progress Report," 1957; David, "Second Annual Report," 1957, 6; and "Manuscript Holdings of the Longwood Library," January 1960, 1-2, Box 162, Folder "Manuscripts holdings," EMHFA/RG4.

212 Following the move to the new library in Delaware, the secure area was enlarged as additional confidential collections were acquired, see Williams, "1963 Report," 6: David, "Second Annual Report," 1957, 13; "Third Annual Report," 1958, 10; "Fourth Annual Report," 1959, 11, 13; and Richmond Williams, “1961 Report,” 5, Box 169, Folder “Annual Reports-Library, 1960-1967,” EMHFA/RG5.

213 “Minutes,” Longwood Library staff meeting, February 5, 1957, 1. 
history and an anniversary project to convert its historic powder works property into a public museum and heritage site.

The E.I. du Pont de Nemours and Company, making use of knowledge gained in France, established its first gunpowder mill on Brandywine Creek near Wilmington, Delaware, in 1802, produced purified saltpeter in 1803, and its first keg of black powder in $1804 .{ }^{214}$ Black powder was important to the new nation, helping to clear the wilderness of stumps and rock, level land for a network of rail, open the earth's mineral resources, and power guns and military armaments. Family connections to Thomas Jefferson influenced the DuPont Company's initial success in supplying explosives to the government during the War of 1812. Federal wartime contracts set the pattern for growth, with DuPont products used extensively in both the Civil War and World War I. Multiple family-owned facilities produced related chemical and explosive products, including smokeless powder, T.N.T., dynamite, guncotton, nitric acid, sulfuric acid, and alcohol. Research laboratories at the Brandywine site (and another in Gibbstown, New Jersey, twenty miles east of Wilmington) made DuPont one of the first major corporations to use scientific research to develop wholly new products. Although the original powder mills closed in 1921, the Brandywine continued as the company's research headquarters. In the twentieth century, DuPont became synonymous with synthetic fibers such as rayon, nylon, Orlon, Kevlar, Tyvek, and Dacron, as well as other plastic products such as cellophane, neoprene, and Teflon, while its industrial dyes and chemicals were raw materials for dozens of other sectors, including nuclear weapons and atomic energy. ${ }^{215}$

${ }^{214}$ Impressions of Hagley (Wilmington, Delaware: Hagley Museum and Library, 1991), [2]; The Hagley Museum: A Chronicle, 23-35; Nash, "Business History at the Hagley Museum," 106.

${ }^{215}$ Nash, "Business History at the Hagley Museum," 108; Craig, "Delicate Balance," 18. The history of the DuPont Company is represented in a wide range of publications, including celebratory works supported by the Company itself such as The History of the E.I. du Pont de Nemours Powder Company: A Century of Success and Dutton's Du Pont. Unauthorized studies of the company include John K. Winkler, The Du Pont Dynasty (New York: Reynal \& Hitchcock, 1935) and Gerald Colby Zilg's enormous work, Du Pont: Behind the Nylon Curtain (Englewood Cliffs, New Jersey: Prentice-Hall, 1974). Alfred D. Chandler utilized the corporate and administrative histories of the DuPont and General Motors corporations as centerpieces to his best-known works, Strategy and Structure: Chapters in the History of the American Industrial Enterprise (Cambridge, Massachusetts, Massachusetts Institute of Technology Press, 1962), and Chandler and Salsbury, Pierre S. Du Pont. Additional scholarly analysis of the DuPont Company may be found in Graham D. Taylor and Patricia E. Sudnik, Du Pont and the International Chemical Industry (Boston, Massachusetts: G.K. Hall, 1984) and Charles W. Cheape Strictly Business: 
Under P. S. du Pont and company treasurer John Raskob, DuPont incorporated in 1899, paralleling many growing enterprises in shifting away from individual proprietorship or partnership organization. A new "big company” was formed in 1903 with the absorption of dozens of smaller explosives and chemical ventures within which the company held controlling stock. Raskob and P.S. du Pont devised novel operational and reporting structures for the new corporation, and P.S. du Pont further consolidated his control of the company with a stock coup in $1915 .{ }^{216}$

Shortly after, the DuPont Company invested some of its early World War I profits purchasing stock in the struggling General Motors Corporation. By 1920 P.S. du Pont and John Raskob exerted significant control over the automobile manufacturer, with du Pont serving as both president and chairman of the board. GM returned to profitability, and in May 1923, P.S. du Pont turned the presidency over to Alfred Sloan (though he and DuPont Treasurer John Raskob maintained close oversight of financial administration). The two companies were intertwined in many ways, with GM becoming a major purchaser of the paints, chemicals, and plastic products developed by DuPont. ${ }^{217}$

The business records of the DuPont Company dated to the founding of the powder mills in 1802. Over time, the company adopted a variety of records-keeping practices. In its earliest years, it was attentive to records-related issues and preserved a variety of historical materials, particularly internal financial records. Entering the twentieth century, older records were stored in wooden powder crates (known as "shook boxes") at a

Walter Carpenter at Du Pont and General Motors (Baltimore, Maryland: the Johns Hopkins University Press, 1995). The development of rayon, cellophane, neoprene, and nylon are nicely summarized in Dutton, Du Pont, and in much more detail in David Hounshell and John Smith, Science and Corporate Strategy: Du Pont R and D, 1902-1980 (Cambridge and New York: Cambridge University Press, 1988). While Dutton provided one of the earliest indications of DuPont's role in the Manhattan project (381 383), Zilg provides a detailed analysis in Du Pont: Behind the Nylon Curtain, 363-365.

216 The History of the E.I. du Pont de Nemours Powder Company: A Century of Success, 214; Chandler and Salsbury, Pierre S. Du Pont 105-107; Winkler, The Du Pont Dynasty, 210-228.

${ }^{217}$ See "General Motors Bonanza," in Winkler, The Du Pont Dynasty, 249-263, and Zilg, Du Pont: Behind the Nylon Curtain, 199-205. The General Motors venture was primarily intended as a profit-making stock investment for the DuPont Company and its related family shareholders. P.S. du Pont never forced business transactions between the two corporations which may have impaired the enormous dividends possible from the two companies' independent success. "In 1926 the dividends the DuPont Company received from General Motors were about \$44 million, while the profits from its sales to General Motors could hardly have been more than \$2 million," Chandler and Salsbury, Pierre S. Du Pont, 565, 583. 
centralized "Hall of Records" on the grounds of DuPont's research facility outside Wilmington. ${ }^{218}$

Around 1950, DuPont modernized its nascent archives. Key records management improvements at DuPont are documented in an extended chapter in a 1957 publication, Case Studies in Records Retention and Control, issued by the Controllership Foundation. The chapter indicates that DuPont had operated a records program for several decades, with one of the records storage buildings (possibly the Hall of Records itself) purpose built in 1945 for the management and storage of records. Following assignment of administrative control to the corporate secretary's office in 1951, DuPont engaged the National Records Management Council to carry out a survey, review, and renovate the Hall of Records to improve handling of semi-active and inactive/historical records. The fifty-page chapter included photographs of both the old and new storage shelving, copies of records transfer forms, and detailed accounts of reference activity during the project period 1951-1953. The project included appraisal of more than 3,000 types of records, covering more than 140,000 cubic feet. Records deemed worthy of retention were repacked into standard cardboard records containers. The chapter included a brochure about the "new and improved" Hall of Records (the eight-page brochure was distributed widely to DuPont staff in 1953). The project increased the capacity of the Hall of Records to 174,600 cubic feet, sufficient for four to five years of growth beyond 1956. Nearly 14,000 cubic feet of records were judged obsolete and destroyed during the project. ${ }^{219}$

Disposals had taken place before the 1951 project. The company had destroyed one particularly large block in March 1937. While the reasons for this earlier disposal are unclear, an inventory of the destroyed items listed dozens of bound volumes of letterpress copy books and shipping information from DuPont and its subsidiaries dating back before

\footnotetext{
${ }^{218}$ David, “The Longwood Library," 1957, 194; Johnson, An Analysis of the Early Record Keeping; Records management practices are described in the undated DuPont circular "Hall of Records Offers New and Rapid Services," issued by the Records Division of the Secretary's Department, Box 149, Folder "Hall of Records," EMHFA/RG4. This circular was also reproduced in its entirety in Jewel Moberley, "E.I. Du Pont de Nemours \& Company," Case Studies in Records Retention and Control (New York: Controllership Foundation, 1957), 439-445. For a good summary of the significant records groups within the DuPont Company records see Nash, "Business History at the Hagley Museum," 108110.

${ }^{219}$ Moberley, "E.I. Du Pont de Nemours \& Company," 403-455.
} 
the Civil War. The loss of this material was discussed by Charles David and Longwood Foundation executives and helped to raise awareness about the importance of the Company's archives to the developing library enterprise. P.S. du Pont had not included DuPont Company records in his plan for the Longwood Library, but crossover with the family papers he had collected certainly existed. ${ }^{220}$

The DuPont Company was attentive to its own history in public ways, too, and in 1926, established a small museum on the ground floor of its main office building in Wilmington. The 30 ' x 40' room featured items relating to the company's early history, including powder kegs, blasting machines, testing apparatus, and historic accounting books. Historical interest increased in the lead-up to the corporation's $150^{\text {th }}$ anniversary in 1952. Luther Reed, a long term DuPont employee and recently retired corporate officer, was put in charge of a program to celebrate the milestone at the site of the original powder mills on the Brandywine. The project suggested the possibility a permanent museum utilizing restored buildings at the site. ${ }^{221}$

To support the museum initiative, DuPont established a separate non-profit educational corporation, The Eleutherian Mills-Hagley Foundation, in 1952. The new Foundation acquired the lands for development of the museum and received substantial cash and stock donations from the DuPont Company and key members of the du Pont family for an endowment. Luther Reed became managing director in charge of development for the museum and restoration of the site. Dr. Walter Heacock, formerly director of exhibit buildings at Colonial Williamsburg, was hired in 1954 to develop and direct the indoor-outdoor industrial museum, with an emphasis on hands-on and immersive visitor experiences. While the Foundation board was made up of former DuPont Company executives and du Pont family members (some of whom fit both

\footnotetext{
220 The two-page inventory of records destroyed in March 1937 is included with a memo from Norman Wilkinson to Charles David, January 22, 1958, Box 363, Folder "Hagley Museum Accessions," EMHFA/RG5.

${ }^{221}$ Parks, “A Sense of Corporate History," 1989, 19; and Laurence Coleman, Company Museums (Washington, D.C.: The American Association of Museums, 1943), 101. Information on Luther Reed is from "Hagley History," an internal document listing Eleutherian Mills-Hagley Foundation leadership, shared to the author by staff of the Hagley Library and Museum.
} 
categories), Heacock was the first "professional" hired by the Foundation and would serve until 1984.222

The Hagley Museum opened in May 1957 in historic buildings, including the 1803 du Pont residence within the Brandywine complex. Museum exhibits illustrated the industrial development of the U.S. in the age of water power. Heacock's approach was to "bring together a small group of qualified historians, supply them with essential working tools in the form of a specialized library, and have them assemble the needed information." As researchers (rather than librarians or archivists), these museum curators and staff gathered manuscript and print materials to support their research and interpretive needs, including more than 2,000 volumes of standard reference works, books on industrial history, and manuscript and photographic items documenting the DuPont mills and other Brandywine factories. The resources of this small working library were soon in constant use by Hagley Museum staff, "since research has been a vital factor in all of our activities and will continue to be."223

DuPont decided that company records dating from 1802 to 1902 had more value to the museum project than the company and transferred them to the museum's library in the mid-1950s where they could be more easily accessed by research staff and other external researchers. Officials were comfortable opening pre-1903 historical records, one telling Charles David "that he felt there was nothing too detrimental or harmful" in the records. The transfer relieved some space pressures at the Hall of Records. Museum staff sorted and cataloged the corporate records, though no evidence survives of their approach to this work. Once designated as the "custodian" of DuPont corporate records, museum staff discovered that they were also responsible for providing a rather extensive reference

\footnotetext{
${ }^{222}$ In addition to the company, "generous support" was provided by Lammot du Pont Copeland and Louise du Pont Crowninshield. Charles David to Frank Francis, July 31, 1959, Box 148, Folder "Eleutherian Mills-Hagley Foundation," EMHFA/RG4. "The Hagley Library Turns Fifty on October 7, 2012," uncredited blog entry, www.hagley.org/librarynews/library-directors-desk-reflecting-hagleys-history accessed November 15, 2014 (print copy in author's collection); "Hagley History;" and Craig, "Delicate Balance," 18;

${ }^{223}$ Quoted section about "qualified historians" is from Heacock and David, "Proposed Revision," 1958, 2. Quoted section about research is from Walter Heacock to Charles David, April 7, 1958, Box 154, Folder "Proposal for a New Joint (Hagley-Longwood) Library Building," EMHFA/RG4. See also Craig, "Delicate Balance," 18.
} 
service for various departments and officials of the company. Heacock sought additional and ongoing transfers of records from the DuPont Company to augment and build the collection for a full representation of company history. But much DuPont material remained in Company control, inaccessible to the public and museum staff. This included most corporate records after 1902 - including materials relating to the ties between DuPont and General Motors - as well as the technical library of published and unpublished resources maintained by the DuPont Company Research Department. ${ }^{224}$

Heacock hired historian Norman B. Wilkinson to develop the research and interpretive program for the Museum. Wilkinson's resume included numerous articles and reviews on industrial history, and he had served as assistant state historian for the Pennsylvania Historical and Museum Commission. Much of Heacock's team's initial research work supported the physical restoration of historic buildings and creation of museum displays on the history of powder making, the story of the du Pont family and DuPont Company, and the broader history of industrial development in the Brandywine region. Museum staff utilized materials held in repositories throughout Delaware and Pennsylvania, the DuPont Company records held at the museum and Hall of Records, personal papers at the Longwood Library, and their own expanding internal library. ${ }^{225}$

By 1961, the Hagley Museum's library held a significant amount of manuscript material. The Company records it held would eventually become "Series I" of the collection known today as the E.I. du Pont de Nemours \& Company Records (550 linear feet, 1801-1901). The materials included correspondence, account books, production and

\footnotetext{
${ }^{224}$ Quoted section is from "Minutes," Longwood Library staff meeting, January 14, 1958, 3. See also "Minutes," Longwood Library staff meeting, February 11, 1958, 2; Charles David to Frank Francis, July 31, 1959; David, "The Longwood Library," 1957, 201-202; and "The Hagley Library Turns Fifty." Eleutherian Mills-Hagley Foundation continues as the legal corporation name, although in 1984 the institution designated Hagley Museum and Library as its official name. Several guidebooks have been published by and about the museum and its special exhibits, including The Hagley Museum: A Chronicle; Glenn Porter, The Workers' World at Hagley (Wilmington, Delaware: Hagley Museum and Library, 1981); and Impressions of Hagley. See also Craig, "Delicate Balance," 18; Walter Heacock to Charles David, April 7, 1958.

${ }^{225}$ Biographical information about Wilkinson from "News and Comment," Pennsylvania History, 43:2 (1976), 186; Norman Wilkinson to Walter Heacock, undated (ca. 1960), "Research Program for the Eleutherian Mills-Hagley Foundation," 2-3, Box 148, Folder "Eleutherian Mills-Hagley Foundation," EMHFA/RG4.
} 
sales records, and materials from dozens of subsidiary companies including cotton, woolen, chemical, and tanning enterprises. Smaller collections in the Museum's library related to individual family members, covering both personal and business records. Outside of the DuPont ventures, the Hagley Museum library also held photograph collections relating to Wilmington-based marine engineering and shipbuilding firm Pusey and Jones (6,700 photographic images, 1865-1955), the papers of a local spice company, as well as "smatterings of records of several smaller firms in this vicinity."226

\section{Non-DuPont Business and Industrial Manuscripts before Consolidation}

In the area of non-DuPont manuscripts, the Longwood Library had gone much further than the museum's library. P.S. du Pont always intended Longwood to grow to include other aspects of "du Pontiana" - a word he coined to describe the history of the family members and their business ventures. But he was also interested in situating family activities within national contexts, intending the library to collect American economic history at a national scale, focusing on the Middle Atlantic States. ${ }^{227}$

Charles David, founding head librarian at Longwood, embraced this vision of a broad research library devoted to American industrial history, looking to the business manuscript collections of Baker Library as a model. ${ }^{228}$

That such a collection is practical and highly desirable has been fully demonstrated by the experience of the Baker Library of the Harvard School of Business Administration which has brought together a tremendous and unique collection of business and industrial material from the geographic region of New England. A similar undertaking is contemplated for our own geographic area. It will require careful planning and conservative direction in order that the material to be gathered shall be representative, of important research value, and not so voluminous as to be unmanageable in terms of our resources. This work of collection must be made major as soon as we

\footnotetext{
${ }^{226}$ Norman Wilkinson to Charles David, April 30, 1962, Box 363, Folder "History of Eleutherian Mills Historical Library," EMHFA/RG5. The 550 linear feet extent for the DuPont papers is taken from Nash, "Business History at the Hagley Museum," 106.

${ }^{227}$ Battan, "Narrative on Development of the Longwood Library," 5; Riggs, Guide (1970), v.

${ }^{228}$ Nash, "Business History at the Hagley Museum," 105.
} 
are established in our new quarters, and it will certainly continue to be major for a good many years to come." 229

If the Longwood Library were to justify itself as a significant national research library, he told local audiences, "it has to devote itself to something more than the du Pont family and company, even though we fully acknowledge the important role which the family and company have played in our national history."230

Like the early staff at Baker Library, Charles David initially believed Longwood could develop its manuscript acquisitions with a national scope. His memo to the Longwood Foundation Board on September 30, 1955, outlined his vision of assembling and making available "a considerable body of primary materials from the archives of a considerable number of important industries." Travelling in the summer of 1955, he discussed the idea with librarians and scholars and met with a great deal of enthusiasm for the venture. ${ }^{231}$

This is not to say that there are not difficulties which have been pointed out to me, the magnitude of which I fully recognize. The most important of these, I think, is the magnitude of the primary materials with which we shall have to reckon. If the Longwood Library is to become an important center of research in industrial history, it will have to be strong not only in printed materials but also in primary manuscript materials out of industrial archives. $^{232}$

During a visit to Boston, David toured Baker Library, and was told of the large volume of manuscripts remaining in private and corporate hands. "The problem will not be to obtain materials," he told his colleagues, "but rather how to keep from being overwhelmed by their mass." David committed the Longwood to responsible collecting, refusing to acquire "such masses that we cannot provide adequate storage for them and bibliographic control over them." In a January 1956 article in the Bulletin of the Special Libraries

\footnotetext{
${ }^{229}$ David, "The Longwood Library - It's Scope and Purpose," 1960, 39.

${ }^{230}$ Quoted section is from Williams, "The Longwood Achievement," 47. See also David [1955 Report], 23; David, "Notes for a talk to the Wilmington Garden Club," 6.

${ }^{231}$ David [1955 Report], 3-6.

${ }^{232}$ David [1955 Report], 3-4.
} 
Council of Philadelphia and Vicinity, David called for a scope of collection that "may range from the beginning of the Industrial Revolution on into the 20th century" and would "contain unique primary materials derived from the archives of various industries." 233

The trustees of the Longwood and Hagley Foundations, however, were not as enthusiastic about such an expansive - and likely expensive - national scope for the Longwood Library. The company-supported Hagley Museum had limited its interpretive and collecting activities "very definitely to stay within the confines of the Brandywine area, not to spread out beyond that." One trustee who heard of Charles David's plan to grow Longwood into a national collection on the history of technology and industry was "appalled by its magnitude." Longwood's staff responded accordingly, reducing their scale "due to the apprehension on the part of some members of our Board lest our program become too ambitious." Imitating the museum, they focused their acquisitions on only Philadelphia, Chester County, southern New Jersey, and Delaware. ${ }^{234}$

This was a frank disappointment for Charles David. But he took the new directive in stride and began to develop a network of communications and colleagues in the narrower region to allow the Library to expand beyond du Pont family and company materials, albeit in a more confined geographic region. "Although the emphasis of the library would be on this geographic area," he wrote, "the economic development of the four state area parallel those of the Atlantic seaboard and reflect the growth of the American industrial society as a whole." Staff began to contact active companies in the region to solicit their historical corporate records. ${ }^{235}$

The 1957 acquisition of records of the Lukens Steel Company (now extended to 700 linear feet, 1798-1993) was the first large collection of non-DuPont corporate records

${ }^{233}$ Quoted sections about "masses" and "mass" are from David [1955 Report], 3-4; See also David, "The Longwood Library, Kennett Square," 1956, 1, 34.

${ }^{234}$ Quoted sections warning not to "spread out" and trustees being "appalled" are from Charles David, "Notes on Conference Held in Lammot du Pont Copeland's Office," January 27, 1956, Box 145, Folder "Annual Reports 1955-1960," EMHFA/RG4. Quoted section addressing their "apprehension" is from David, "Second Annual Report," 1957, 6; David, "Brief Progress Report," 1957, 3.

${ }^{235}$ Quoted section is from Eleutherian Mills-Hagley Foundation, "News Release," July 18, 1961, Box 148, Folder "Eleutherian Mills-Hagley Foundation," EMHFA/RG4. See also Williams, "The Longwood Achievement," 51. 
obtained by the Longwood Library. Lukens originated in 1790 as an iron mill, rising to significance in the 1810s under Charles Lukens, producing the first boiler plate in the United States. At the time of the Longwood project, Lukens was one of the oldest regional firms still under original family control, operating at Coatesville, Pennsylvania, just fifteen miles from the Longwood Library. ${ }^{236}$

Since the collection would be a "test case setting a precedent for future policy," Charles David sought Longwood Foundation approval. Rather than an outright gift or purchase, the Lukens records were handled through a deposit agreement. In March 1957, David, John Riggs, and Frank Battan traveled to Coatesville and selected five loads of records dating from 1790 to 1890 . The records arrived in bad physical state, both in terms of organization and preservation. Staff gave the material a preliminary cleaning before arranging in boxes and inventorying. Carpenters added wooden shelving to the Longwood mansion's garage to house the records, while staff completed an initial listing of contents. ${ }^{237}$

The Lukens collection consisted of more than 200 bound volumes, including core accounting journals, ledgers, cash books, and other bank books, as well as letterpress copy books of outgoing correspondence. An additional set of 120 boxes held loose documents, sales orders, production and shipping records, and a set of incoming correspondence. Unlike the du Pont family papers, staff applied an "archives approach" to the Lukens records, with only collection-level and series-level descriptions reflecting the structure and departments of the corporation. Bound volumes were listed separately if

\footnotetext{
236 "Minutes," Longwood Library staff meeting, April 3, 1957, 1, and David, "Notes for a talk to the Wilmington Garden Club," 7.

${ }^{237}$ While working through the records, the Longwood staff discovered additional materials relating to the Lukens and Pennock families, including property deeds dating to the 1770s and a manuscript journal of Elizabeth Webb, a Quaker who traveled the eastern seaboard states in 1698. As the deposit agreement only extended to corporate records, such family papers and other correspondence were returned to the Lukens family descendants. See "Minutes," Longwood Library staff meetings, January 15, 1957, 1, February 5, 1957, 1; June 29, 1957, 3; September 15, 1961, 5; and November 7, 1961, 3. See also David, "Second Annual Report," 1957, 6; David, "Third Annual Report," 1958, 2, 8.
} 
needed, but loose items were described at the folder level as an efficient balance between accessibility and the time-consuming work of item-level cataloging. ${ }^{238}$

Following the Lukens project, Charles David acquired the records of the Northern Liberties Gas Company of Philadelphia (40 linear feet, 1686-1958), one of the oldest gas manufacturing companies in the region. He saw these records, also, as a test case that would set precedent for Longwood's acquisition of industrial manuscript material beyond DuPont, and he worked closely with the Board throughout the acquisitions process. ${ }^{239}$

As the regional community of collectors and auction houses became aware of Longwood's acquisition activity, they offered manuscript items for purchase; sometimes single daybooks or individual documents. The Library was initially unsure about such purchases. Frank Battan and Grace Ottey felt comfortable buying single items, expecting that if Longwood went on "gradually accumulating" such items that they would "fit together and ultimately form a pattern." 240

John Riggs, however, was resistant to the purchase of materials "not positively germane to the existing papers as they stand now," particularly if they were small collections or individual items. Riggs was opposed to growing the collections while there was still so much work to do in the existing du Pont collections. "It is time consuming to process it," he noted, and he attempted to assert authority over any potential purchases as manuscript curator. ${ }^{241}$

Ongoing questions concerning the scope of external industrial collections - and ongoing friction between Riggs and other staff - would play out for many years. Planning for an exhibit of manuscript materials in June 1960, for example, Charles David suggested including pieces from the Lukens Steel and other non-DuPont collections. Riggs complained that there was enough to draw simply from the du Pont family papers, but David saw an opportunity to reach out to his developing regional network of business

\footnotetext{
238 See the description of Accession 50, "Records of the Lukens Steel Co., of Coatesville, Pa., c.17981944,” in Riggs, Guide (1970), 855-857.

${ }^{239}$ David, [First Annual Report], 1956, 8; “Minutes," Longwood Library staff meeting, January 15, 1957, 2 .

240 “Minutes," Longwood Library staff meeting, July 17, 1959, 4.

241 “Minutes," Longwood Library staff meeting, July 17, 1959, 4.
} 
owners and donors, hoping to encourage their participation by exhibiting "a place for their materials" at the Library. ${ }^{242}$

As was the case at Baker Library, imprints became an important complement to manuscript materials at the Longwood Library. These included monographs and serial titles collected by P.S. du Pont about his ancestors, titles printed by the du Pont Press in France, works on French genealogy, and a variety of books by and about Antoine Lavoisier, local history, gunpowder manufacture, and horticulture. The imprint collection also included company and trade catalogs, marketing materials, and the proceedings of business and manufacturing associations. Longwood adopted the Library of Congress system of classification for its shelving arrangement ("being the most suitable for a research library such as ours"). However, Longwood had to produce many of its own cards for unique items not held by LOC and, over time, began sending duplicate catalog cards to both LOC and Charles David's Union Library Catalog project. ${ }^{243}$

As the manuscript collections came under closer control, Longwood Library staff undertook a variety of activities to promote the new library enterprise. Following up on his 1956 article in the Bulletin of the Special Libraries Council of Philadelphia and Vicinity, Charles David delivered a paper to the Bibliographic Society of America in May 1957, subsequently published in their proceedings and distributed, via reprints, to the Foundation Board and the du Pont family. John Riggs produced his own brief report in January 1960 entitled "Manuscript Holdings of the Longwood Library," which, Charles David reported, "received wide publicity both in this country and abroad."244

242 "Minutes," Longwood Library staff meeting, June 22, 1960, 3.

243 David, “Third Annual Report," 1958, 3; David, “The Longwood Library," 1957, 191; Butler, "Narrative," 1955, 6; Williams, “1963 Report,” 6; Williams, "Preliminary Draft," 1973, 5. See descriptions of the Special Conference Committee, the National Industrial Conference Board, and the National Association of Manufacturers (NAM) in Nash, "Business History at the Hagley Museum," 116 117. Glen Asher also discusses records of the NAM at Hagley, as well as materials from the American Iron and Steel Institute (AISI) and the Society for the Plastics Industry (SPI), see Asher, "Researching," 765-6. Trustees at the Longwood Foundation cautioned staff not to compete with local libraries or other special collections in the region for resources, including the University of Pennsylvania and Bryn Mawr, see "Minutes," Longwood Library staff meeting, July 17, 1959, 3; David, [First Annual Report], 1956, 7, 8; and David, “Third Annual Report," 1958, 1; "Handbook for Guides,” 1961, 13-14.

${ }^{244}$ Quoted section about "wide publicity" is from David, "Fifth Annual Report," 1960, 10. Perhaps as part of the ongoing divisions between the two men, Charles David doesn't mention Riggs by name, only referring to the document as "A notable minor achievement of the Manuscripts Department, or rather of 
P.S. du Pont believed that the value of the manuscript collection would only be proven through its use for research and publication. Thus, as he developed his concepts for a publicly accessible library, he was also attentive to attracting and supporting graduate students and other scholarly researchers. Within a few months of du Pont's death, Frank Battan prepared a list of more than thirty research and publication projects that P.S. du Pont had personally started or completed - and which Battan thought the new Library should pursue. Charles David committed the Library to research fellowship, scholarship, and subsidized publication programs, though the mechanics and funding were still to be determined. ${ }^{245}$

Staff quickly encountered problems using a historical residential building for a research library. When Charles David arrived in the summer of 1955, the settlement of P.S. du Pont's estate wasn't yet completed. The mansion still held a large amount of furniture, dishware, linens, and other household belongings. David commented: "It is not at all clear to me how we shall manage for adequate shelving space when our planned acquisitions program gets going in an important way." He presented the Foundation with various plans to convert some of the household spaces into offices, workrooms, and additional collections storage areas. Meanwhile, Frank Battan sent periodic letters through 1958 to more than thirty "immediate" members of the du Pont family seeking to distribute the household contents. ${ }^{246}$

Not surprisingly, the building was not designed for a large collection of heavy books, bound industrial accounting volumes, and boxes of corporate records. Apart from shelving installed along walls, the main portions of the house had to be used for administrative, cataloging, processing, and public research spaces. Painting and refurbishing occurred on a room-by-room basis as spaces became available. Staff and researchers lodged complaints of inadequate lighting throughout the building. ${ }^{247}$

\footnotetext{
its Curator." An updated version, titled "Manuscript Holdings-May 1962," is in Box 363, Folder "Manuscript Holdings-Circular,” EMHFA/RG5. See also David, “Second Annual Report,” 1957, 12. 245 David, "Longwood Library Program as Presently Conceived," 1, 7; Butler, "Narrative," 1955, 5. ${ }^{246}$ Quoted section about "adequate shelving space" is from David [1955 Report], 7; David, "Second Annual Report,” 1957, 1; David, “Third Annual Report,” 1958, 3.

${ }^{247}$ David, [First Annual Report], 1956, 6; David, "Third Annual Report,” 1958, 3.
} 
Solutions for collection storage initially focused on renovating the mansion's garage. The main floor was converted to house 18,000 manuscript and print volumes, with a portion of the basement converted into an expanded photographic laboratory. Work on the garage was complicated by the arrival of the Lukens and Northern Liberties Gas records. Following this, a "considerable rearrangement of shelving and materials in the two vaults under the Mansion House" allowed a better integration of books and manuscripts. Unfortunately, access to the lower level vaults was limited to a rear stairway and an "Elevette" lift which P.S. du Pont had installed. While a "perfectly legal device for a gentleman's residence," the State Fire Marshal found it a fire hazard for a public library operation. Charles David devised a plan to upgrade the elevator, but also established procedures to ensure two modes of exit from the basement vault. ${ }^{248}$

From the outset, however, Charles David realized that much more space would be needed if the Longwood Library was going to pursue its long-term expansion plans. He proposed engaging an architectural firm to design an addition with a modern, four-tier, fireproof, air-conditioned stack building. Although this plan did not find favor with the Longwood Trustees, it drew the Board's attention to alternative options for housing the collection. This included the possibility of moving the collections to Wilmington. ${ }^{249}$

\section{Consolidation of The Longwood Library and The Hagley Museum}

During the years following P.S. du Pont's death in 1954, the Longwood Library and the Hagley Museum operated as separate enterprises at separate locations with separate endowments, separate governing boards, separate budgets, and separate staffing. One focused on family history; the other on corporate history. Charles David's expansion of Longwood into non-DuPont business records, however, had challenged this division, creating opportunities to see three strands of collecting (family papers, DuPont Company

\footnotetext{
248 David, [First Annual Report], 1956, 5; "Second Annual Report," 1957, 1, 3, and "Third Annual Report," 1958, 2; "Minutes," Longwood Library staff meeting, April 3, 1957, and June 29, 1957.

${ }^{249}$ Williams, "Preliminary Draft," 1973, 4; David, [First Annual Report], 1956, 8; Heacock and David, "Proposed Revision," 1958, 4; Williams, "The Longwood Achievement," 51; Heineman, "Eleutherian Mills Historical Library," 1971, 4; David, "Second Annual Report," 1957, 4.
} 
history, and non-DuPont business manuscripts) as parts of an integrated whole. One additional component to P.S. du Pont's personal enterprises - the formal Longwood Gardens - however, seemed discordant. ${ }^{250}$

Discussions of a possible merger of the Longwood and Hagley operations became more frequent in 1957 and 1958. Charles David spoke against the artificial separation of du Pont family papers at Longwood, DuPont Company records, and the history being interpreted at the museum. "The association between family and company during the first hundred years," he wrote, "was so intimate that the attempt to divide the records ... is extremely difficult and inconsistent in practice." From a budgetary standpoint, he argued, the financial support of two similar libraries was "hardly good economy." Walter Heacock agreed that the division was largely artificial. "[T]he usefulness of both collections for research would be considerably enhanced by their integration in a single collection." Heacock also saw administrative and professional advantages in such a merger. "The prospect of joining those collections with our own appeals to our staff for two reasons," he wrote to David. "It would facilitate our own research, and the joint collection would constitute a library of considerable value to scholars in general." 251

Yet Heacock had some reservations about moving library materials from the Hagley Museum to a new joint facility. His research staff needed to have easy access to the collections for their work. He noted: "If our collection goes into the new building under discussion, the staff must also be housed there." Finally - and not insignificantly he felt that moving collections and staff to a new library must lead to additional staff lines for the museum's interpretive program. ${ }^{252}$

Between December 1956 and February 1958, Charles David and Walter Heacock prepared proposals for a joint research library at the Brandywine site to house the

${ }^{250}$ Charles David complained to the Longwood Foundation trustees that his counterparts at the Longwood gardens had disregarded their budget limits for the purchase of botany books. "Minutes," Longwood Library staff meeting, April 9, 1957.

${ }^{251}$ Quoted section about dangers of dividing the records is from David, "The Longwood Library," 1957, 201-201; Quoted sections from Heacock are from Walter Heacock to Charles David, April 7, 1958. See also Heacock and David, "Proposed Revision," 1958, 5-6.

${ }^{252}$ Quoted section is from Walter Heacock to Charles David, April 7, 1958. See also Charles David to Frank Francis, July 31, 1959, Box 148, Folder “Eleutherian Mills-Hagley Foundation,” EMHFA/RG4. 
combined manuscript collections of Longwood and the Hagley Museum and their staffs in a single, new, purpose-built facility. The two suggested the specific site where the building would eventually be built, estimated the square footage for various uses (including 10,000 sq. ft. for collections), and provided estimates for design, construction, furnishings, and landscaping. The proposals outlined the many advantages of a joint library facility, including the research needs of the museum staff and fellows from the Hagley-University of Delaware program. Written for du Pont family members seated on both Foundation boards, their report lauded the project as creating a single wellorganized repository for du Pont family papers, an integrated archives and "show place" for DuPont Company history, and an important collection of manuscript records for scholars across the country. ${ }^{253}$

In October 1958, the Longwood Board approved the merger. Although acquisitions and cataloguing work continued at Kennett Square, no additional physical changes were made to the Mansion House. Longwood staff were assured that there would be a place in the new organization for every employee, that fringe benefits would continue, and that years of service would extend to the new entity. Contractors broke ground in fall of 1958, with the Longwood Foundation financing construction of the library before receding to Pennsylvania to focus on management of the Longwood Gardens as a standalone operation. The Longwood Foundation made a one-time transfer of $\$ 10$ million from its endowment and, upon completion of the new library building in

\footnotetext{
253 The revised proposal in February 1958 addressed the trustees' concern to limit the scope of future collecting, but a close comparison between the original and revised proposals reveals that the second proposal actually increased the stack capacity by $33 \%$. The authors conveniently removed estimates for furnishings, equipment, and landscaping from the second proposal, claiming that "until an architect has been employed and has drafted preliminary plans, we hardly see how definite figures can be suggested for such items." As a result, the revised proposal estimated costs much lower at only $\$ 686,500$ - even though the new plans increased overall square footage for both staff and collections. The two proposals are Walter Heacock and Charles David, "Proposal for a Joint Research Library on the Brandywine to Serve the Interests of the Longwood and the Eleutherian Mills-Hagley Foundations," December 12, 1956, and Walter Heacock and Charles David, "Proposed Revision to a Document dated 12 December 1956," February 24, 1958, both in Box 154, Folder "Proposal for a New Joint (Hagley-Longwood) Library Building," EMHFA/RG4. See also David, "Brief Progress Report," 1957, 5, and David, "Second Annual Report," 1957, 4.
} 
1961, the Eleutherian Mills-Hagley Foundation assumed complete oversight of the combined operation. ${ }^{254}$

Staff were concerned about their administrative change between Foundations. "[O]nce the new building was up and our collections were moved," one staff member worried, "we were to be given to the [Eleutherian Mills-Hagley] Foundation lock, stock and barrel." In an effort to reassure Library staff, the new institution's management structure established separate museum, library, and maintenance divisions on equal administrative footings, with a General Director overseeing the entire operation. Although the stated intention was to hire the director from a museum background, the Trustees initially turned to the DuPont corporate community for a trusted person to move the fledgling organization through this consolidation. In July 1959, Philip Kimball was installed as executive vice president of the Foundation and given the task of harmoniously merging the two previously independent entities. A distinguished engineer, Kimball had recently retired as assistant general manager of the DuPont explosives department, joining the board of the Eleutherian Mills-Hagley Foundation. Kimball became the de facto executive head of the whole enterprise and was ultimately named General Director of the combined operations, a position he would hold until 1966. ${ }^{255}$ Charles David identified several models in which "a library and a museum are operated successfully as a joint enterprise," including London's British Museum and the Huntington Library in California. At David's suggestion, Kimball visited with Frank Francis, director and principal librarian at the British Museum, in London in September 1959. Kimball reported to David that he had a "pleasant talk" with Francis, commenting

\footnotetext{
${ }^{254}$ Some parts of the Longwood collections, particularly the botanical-horticultural imprints and catalog cards were segregated and left behind at Longwood to be managed separately by a librarian hired by Longwood Gardens in July 1960. For details on the transition see David, "Fifth Annual Report," 1960, 1; David, "Fourth Annual Report," 1959, 1; Craig, "Delicate Balance," 21; Heineman, "Eleutherian Mills Historical Library," 1971, 10, and "Minutes," Longwood Library staff meeting, December 17, 1959, 2; David, "Second Annual Report," 1957, 5; "Minutes," Longwood Library staff meeting, October 7, 1958, 3, and October 24, 1958, 3; and "The Hagley Library Turns Fifty."

${ }^{255}$ Quoted section about "lock, stock, and barrel," is from "Minutes," Longwood Library staff meeting, December 17, 1959, 2-3; Charles David to Frank Francis, July 31, 1959; "Hagley History," 4;, and "The Hagley Library Turns Fifty.”
} 
that the impetus toward "a co-ordinated institution" with both museum and library was indeed very similar to that of the British Museum. ${ }^{256}$

Charles David and Frank Battan, meanwhile, traveled to Dearborn, Michigan, to investigate "the great Ford project called the Edison Institute," which included the Ford Museum and Greenfield Village. Although no specific mention was made of the Ford Motor Company Archives during this visit, it seems likely that David and Battan discussed shared experiences with Ford staff. David did report to his staff the public relations role a museum could have for its related company, in addition to serving as a tax shelter through donations of cash, land, buildings, and collections. ${ }^{257}$

Word soon started to leak out about the Longwood-Hagley merger and staff began to speak openly about it with colleagues, donors, and the public.

Late in 1960 or in 1961 the Longwood Library is to be removed from Longwood and merged with the Hagley Museum Library (Eleutherian Mills-Hagley Foundation). The combined library, to be known as the Eleutherian Mills Historical Library, will occupy a new building now being erected on the original property of the DuPont Company overlooking the Brandywine. 258

In October 1960, Baker Library asked to include the Hagley museum's library in a guide to libraries holding pre-twentieth century imprints in economic history. Although Baker made separate requests to both Longwood and the Hagley Museum, Charles David submitted a single entry for the Eleutherian Mills Historical Library (EMHL). The entry defined the institution's geographical scope as "having the Brandywine Valley as its focal point" but extending outward to include eastern Pennsylvania, New Jersey, Delaware, and Maryland. Public statements about the newly combined venture stressed that its

\footnotetext{
256 "In some ways when the institutions get very large," he warned, "the conjunction of the two types of institutions presents awkward problems of administration, control, space, [and] varying conceptions of function." The basic idea, however, was a sound one "and the expertise of the curators can be fully exploited for the benefit of all sides of such an institution," Charles David to Frank Francis, July 31, 1959.

257 “Minutes," Longwood Library staff meeting, October 24, 1958, 3.

258 "Manuscript Holdings of the Longwood Library," 1960, 3.
} 
primary mission was to preserve manuscripts, with imprints providing a support and contextual role. ${ }^{259}$

As plans for the merger progressed in the late 1950s, so, too, did Charles David's retirement plans. The completion of the new library would mark an appropriate end to his eight years of establishing and building the program. The Longwood and Hagley Foundation Trustees decided to hire an "understudy" to work alongside and replace their founding library director. The trustees seemed most interested in attracting "younger or middle aged" candidates with library experience and significant research and scholarship who might lead the organization for many years. ${ }^{260}$

The trustees ultimately selected Dr. Richmond Williams, who began as Associate Director and Charles David's understudy on May 1, 1961. Williams held a PhD in European History from the University of Pennsylvania, and his research interests in nineteenth-century French, English, and American relations provided good linkage to the transfer of economic and industrial knowledge represented by the du Pont family and business manuscript collections. He was also well versed in the crossover areas between archives, libraries, and museums, having spent 1956 to 1960 as director of the Wyoming Historical and Geological Society in Wilkes-Barre, Pennsylvania. During his tenure there, he supervised a complete renovation of the society's facilities, expanded the museum program, and reorganized the library operation. He served as faculty with the Institute on Pennsylvania Life and Culture and the Seminar on American Culture in the Cooperstown program in historic preservation. At the time of his appointment, he had

259 Dorothea Reeves to Charles David, October 17, 1960, Box 149, Folder "Harvard University," EMHFA/RG4. The letter is accompanied by the two-page submission Charles David which was published in Dorothea D Reeves, Resources for the Study of Economic History: A Preliminary Guide to Pre-Twentieth Century Printed Material in Collections Located in Certain American and British Libraries (Boston: Baker Library, Harvard Graduate School of Business Administration, 1961).

${ }^{260}$ Charles David "told Mr. Copeland if his health permitted he would stay with the job until the building was erected and he had the operation going," "Minutes," Longwood Library staff meeting, October 24, 1961, 3, and December 17, 1959. Correspondence about the search process includes Charles David to Arthur P. Dudden, July 18, 1960; Arthur Johnson to Charles David, November 1, 1960; and Charles David to Lammot du Pont Copeland, August 25, 1960, all in Box 159, Folder "Personnel: Files for the Search for the Understudy for the Directorship," EMHFA/RG4. 
just completed a national survey of historical societies in his role as Assistant Director at the American Association for State and Local History. ${ }^{261}$

Williams worked with Charles David until the latter's retirement on December 31, 1961. He stepped into the full role of director of the new merged library in 1962 at age 36 and would hold the position until his own retirement in 1987. Like David, Richmond Williams was active professionally, serving as president of the American Association for State and Local History, secretary of the Economic History Association, and member of American Council of Learned Societies, the National Historical Publications and Records Commission, and the Delaware Humanities Council. ${ }^{262}$

The merger and leadership change were consummated in 1961 with the opening of the new Eleutherian Mills Historical Library (EMHL). It took four days in July to move the Longwood collections to the new facility. Relocation of collections from the Hagley Museum's library was completed a month later. In addition to the combined collections, the building also housed 26 staff from both former sites and offices for Foundation executives Philip Kimball and Luther Reed. ${ }^{263}$ Occupying a single, shared

${ }^{261}$ Charles W. David to members of the Longwood Library Staff, "An important new appointment," February 15, 1961, Box 159, Folder "Miscellaneous Subjects, 1955-1957; and "Hagley History," 5.

${ }^{262}$ Charles David mentored Richmond Williams for seven months, helping to set the new Library into motion. He officially retired from Hagley on December 31, 1961. Not content to step completely away from the library profession, he accepted an invitation from Henry B. du Pont to help with the development of the marine library at Mystic Seaport in Connecticut. In 1965, a group of colleagues published a short volume of salutary essays about Charles David's life, John Riggs, editor, Charles Wendell David: Scholar, Teacher, Librarian (Philadelphia: Union Library Catalog of the Philadelphia Metropolitan Area, 1965). They also organized an event in March 1965 to celebrate his accomplishments on the occasion of his $80^{\text {th }}$ birthday. See John Lewis, "Introduction," 1965, 8-9; Williams, "1961 Report," 5; "Richmond Dean Williams," (obituary), The News Journal (Wilmington, Delaware), October 25, 2014, http://www.legacy.com/obituaries/delawareonline/obituary.aspx?pid=172927963 accessed November 15, 2014; and "Minutes," Longwood Library staff meeting, October 24, 1961, 3.

263 The New York architectural firm of Vorhees, Walker, Smith, Smith, and Haines were the designers, and the contractor was the Baton Construction Company of Philadelphia, see "News Release," 1961, and Williams, "1961 Report," 2. Although nothing was lost or damaged, many issues arose during the move. The crew from the Atlas Storage Company were very capable, but the project was somewhat poorly planned and executed, with library staff pitching in much more than expected. Some of the problems were also caused by delays in the construction schedule. Approval for the move came with very short notice to the moving company which, due to a prior commitment, had to suspend the Longwood move for an entire day in the middle of the project, see "Minutes," Longwood Library staff meeting, September 15, 1961, 4. The DuPont Company continued to operate its Hall of Records for its post-1902 records, as well as a non-public technical library with reference and serial imprints for use by its engineers and research scientists, see "Minutes," Longwood Library staff meeting, February 11, 1958, 2. 
space for the first time, Richmond Williams noted that the collections "complement each other in a remarkable fashion and together constitute one of the strongest collections of its kind in existence."264

A series of events in the fall of 1961 formally initiated the new operation. A preview open house allowed more than 200 staff and board members from the two Foundations, Longwood Gardens, and the Winterthur Museum to tour the facility. But the main event was an extravagant dedication event on October 7 that included more than 500 guests. The event featured a program of dedicatory speeches and the formal transfer of the building and the collections from the Longwood Foundation to the Eleutherian Mills-Hagley Foundation. Paul Buck, director of the Harvard University Library, delivered the keynote address, asserting that no other repository would rival the combined collections. An additional 500 members of the public took advantage of public visitation arrangements in the following weeks. ${ }^{265}$

A special exhibit included manuscript letters from many of the du Pont family, as well as from Franklin, Jefferson, Washington, and John Quincy Adams. It also highlighted items from the DuPont corporate records, including one of the six original cartons used to ship du Pont family and business records to the United States in 1799. Perhaps playing to the Trustees of the two foundations, the exhibit did not include any items drawn from acquisitions outside the du Pont family and corporate enterprises. Following the dedication, Hagley published a 68-page illustrated booklet with the complete text of all speeches and a catalog of the exhibit materials. About 4,000 copies

\footnotetext{
${ }^{264}$ Williams, "1961 Report," 2.

${ }^{265}$ In his talk, entitled "The Historian, the Librarian, and the Businessman," Buck compared the history of the du Pont family with that of the John Adams family of Massachusetts, noting both families' interest in collecting personal papers and opening them for public research. His remarks also addressed the distrust between businessmen and historians - but also pointed to the corporate records of the Ford and Firestone companies becoming publicly available in standalone repositories. "But worthy as are these ventures," Buck noted, "none rivals the collection we dedicate today." See Eleutherian Mills Historical Library: A Record of Its Dedication, 1961, 9-14. See also Williams, "1961 Report," 1; and Nash, "Business History at the Hagley Museum," 105.
} 
were distributed to individuals and institutions in the United States and Europe, the product of consolidating the Longwood and Hagley Museum mailing lists. ${ }^{266}$

The new Library building had a modern, functional design. At its center was a three-level closed stacks area, surrounded by offices and work areas. Public spaces included an entrance area, a reading room, and a rare book room that could be used for public gatherings and lectures. The building was fully air-conditioned and as fireproof as modern construction could make it. The stacks area measured 17,300 square feet, though only 10,000 feet were initially equipped with shelving. ${ }^{267}$

\section{Rapid Expansion of Manuscript Collections, 1961-1982}

The completion of the new library building in 1961 led to a period of rapid expansion that lasted two decades. Early in this period, the new Hagley Library (still under the EMHL name) updated administrative and staffing structures, developed descriptive and promotional tools to draw attention to the institution, initiated new types of public programming, and began to significantly expand its non-du Pont collections. It is useful to look at each of these developments in turn.

Operating the newly consolidated operations created some problems. Some staff retained loyalties to their pre-merger collections and operations. Charles David, before he left, pushed both museum and library staff to move on: "[T]he Longwood Library no longer exists and Hagley Library no longer exists," he noted, "there is only one library here ... and we operate it." Richmond Williams and Walter Heacock worked with the Foundation Trustees to establish a number of committees to encourage cooperation between the previously separate staffs. In addition to a research committee, they formed a publications committee and other intra-departmental groups to address changes in

\footnotetext{
${ }^{266}$ A detailed catalog of the exhibit contents is included in Eleutherian Mills Historical Library: A Record of Its Dedication, 1961, 19-59. Trained guides led tours of the new building and participants enjoyed a small souvenir pamphlet and a luncheon catered by the Wilmington Club. An internal handbook was written to help Hagley guides to understand - and share to visitors - the background of the Longwood and Hagley collections, the construction project, and plans for its expansion, see "Handbook for Guides," 1961, 3. See also Williams, "Preliminary Draft," 1973, 7; and Riggs, "1963 Report of the Department of Manuscripts," 4.

${ }^{267}$ Eleutherian Mills Historical Library: A Record of Its Dedication, 1961, 61.
} 
operational philosophy and procedure. These groups provided a useful place for staff from both units to have a "working level interchange." Work also began to comingle material from the two collections into a cohesive whole. Cataloging librarians began immediately to integrate imprints from the Hagley Museum library into the much larger and better-cataloged Longwood collection. ${ }^{268}$

Within Williams' portion of the operation, the organizational structure remained largely unchanged. Staff in most key positions were expected to be "professionally qualified" for their duties. During the construction and transition, both Charles David and Richmond Williams discovered that the Longwood Foundation had provided many services that they now had to assume and fund. These included staff to operate a reception desk and central switchboard, grounds maintenance, accounting, and other administrative services. ${ }^{269}$

To further ease the transition, Williams encouraged staff to attend professional conferences, distribute literature about the collections, promote the library through presentations, and, when possible, publish articles in professional newsletters and journals. Likewise, the Longwood and Hagley foundations made a conscious commitment to fund staff professional development, continuing education, training, and travel. These commitments placed Hagley representatives at major professional meetings and conferences, building the reputation of the entire enterprise. These included archival and library associations, but also business and industry professional settings, such as the National Industrial Conference Board, the Business History Association, and the Economic History Association. ${ }^{270}$

${ }^{268}$ Quoted section "we operate it" is from "Minutes," Longwood Library staff meeting, October 24, 1961, 1. See also Williams, "1964 Report," 1; Williams, "1961 Report," 3.

${ }^{269}$ Heineman, "Eleutherian Mills Historical Library," 1971, 4; David, "The Longwood Library - Its Scope and Purpose," 1960, 1; "Handbook for Guides," 1961, 3; Williams, "1961 Report," 1-5.

${ }^{270}$ Williams helped create the Council of Historical Libraries of Delaware (CHiLD), a group which sought to discourage competition between collecting repositories in the state. It was also instrumental in a number of cooperative efforts, including the microfilming of newspapers. He served on the editorial advisory board for the Business History Review and was eventually elected Secretary-Treasurer of the Economic History Association. He was also appointed to serve as a commissioner on the National Historic Publications and Records Commission at the National Archives and Records Administration. See Williams, "1962 Report," 2-3, 6, 12-13; Williams, "1963 Report," 11-12; Williams, "1964 Report," 1; Williams, "1966 Report,” 2; Williams, "1970 Annual Report,"10-11; Williams, "1975 Annual 
The new Hagley Library also supported training in new skills and upgrading professional qualifications, such as providing unpaid leaves for David Gilchrist and Marie Windell to complete doctoral research. It also provided tuition and release time for coursework and training, in one case promoting Mrs. Hildegard Rink rather than seeking an outside replacement to fill a vacancy. In another case, the Library supported two members of the Manuscripts Department at the "Modern Archives Institute," a two-week intensive course in modern archives management run by the National Archives and Records Service and American University. ${ }^{271}$

Thus, through a conscious and deliberate program of professional development and travel support, the Library eased the pangs of transition and expanded its network of academic and professional contacts at the important and relevant professional meetings under Williams. Ultimately, these programs promoted the collections and built the reputation of Library within the academic community. ${ }^{272}$

As the merged institution smoothed the bumps of consolidation and encouraged staff professional activity after 1961, it also developed other tools to draw the attention of researchers and external audiences. John Riggs' short brochure on "Manuscript Holdings" was enlarged to include non-DuPont materials and distributed to chairs of academic history departments. And the Library reported collection information to the National Union Catalog of Manuscript Collections (NUCMC), which beginning in 1959,

Report," 4; Williams, “1976 Annual Report.” 18, Box 169, Folder “Annual Reports - Library, 19601967," EMHFA/RG5; and John Riggs, "Annual Report-1976," Manuscripts and Archives Department, 6, Box 365, Folder "Annual Reports, 1956-1986," EMHFA/RG5.

${ }^{271}$ Williams attempted to codify the support the Foundation would provide to individuals. His "Draft Foundation Policy on Support of Staff Members' Professional Activities," suggested financial support for up to four professional speaking engagements per year, attendance for at least one professional conference, and support for holding office in one regional or national professional organization. While staff could accept honoraria for invited talks and could request up to two days per month to undertake paid consulting work, Hagley held no involvement with these transactions, see Richmond Williams, "Draft Foundation Policy on Support of Staff Members' Professional Activities," April 11, 1973, Box 373, Folder "Acquisition Policy," EMHFA/RG5; Richmond Williams, "1965 Report," 6, Box 169, Folder "Annual Reports - Library, 1960-1967," EMHFA/RG5; Williams, "1975 Annual Report,” 4. For background on the Modern Archives Institute, see Bruce Ambacher, "The Modern Archives Institute: A History and Profile of Recent Students." Archival Issues, 18:2 (January 1, 1993), 109-19.

${ }^{272}$ Williams, "1969 Annual Report," 12; Evald Rink, Printing in Delaware (Wilmington, Del: Eleutherian Mills Historical Library, 1969); Williams, "1970 Annual Report," 1, 12. 
published a series of printed index guides to manuscript holdings widely used by researchers. ${ }^{273}$

Yet, Riggs' brochure and NUCMC did not provide very much detail about the vast manuscript collections already gathered at Hagley. To disseminate detailed information, major manuscript repositories at the time sometimes published book-length guides. Riggs envisioned such a publication for the Library's du Pont family holdings. Although it is not clear what opinion Richmond Williams had about the project, the Foundation's Advisory Committee approved "Dr. Riggs' proposal" in April 1963. 274

Riggs' guide, which focused on the Library's du Pont family holdings but included its other manuscript collections, proved more difficult than first imagined. It would not reach printed form until 1970. Internal documentation does not explain the full reasons for the drawn-out process, but it is likely that John Riggs' preference for itemlevel description proved a major stumbling block. To succeed, the collections had to be fully processed - inventoried, integrated, and cataloged - so that the guide would have everything in its proper place when it went to print. Richmond Williams' annual reports imply frustration with Riggs' slow progress. In 1965, the project was "gathering momentum" with staff tying up loose ends of checking, labeling, and arranging 820 separate accessions. In 1966, completion was "now in sight," but 1967 still only found them "practically ready for final typing," with Riggs promising the guide would be completed in 1968. Williams was finally able to report that the manuscript was at the printer in his report dated January 22, 1970."275

The final product, A Guide to the Manuscripts in the Eleutherian Mills Historical Library; Accessions Through the Year 1965, was a formidable tome at 1,200 pages, including an exhaustive 200-page index. It included item-level descriptions of most of the

\footnotetext{
273 “Manuscript Holdings-May 1962;" John Riggs, “Operations in the Manuscripts \& Archives Department," December 15, 1977, 2, Box 363, Folder “Operations of M\&A Department," EMHFA/RG5; "Minutes," Longwood Library staff meeting, November 26, 1958, 5.

274 "Minutes," Longwood Library staff meeting, January 6, 1960, 3; Williams, "1963 Report," 5; David, "The Longwood Library," 1957, 200.

${ }^{275}$ Ironically, David Gilchrist - who sparred with Riggs frequently as Specialist in Industrial Collections would provide the final editing and printing in his new role as head of the Publications Department. See Riggs, Guide (1970), xix; Williams, "1965 Report," 3; Williams, “1967 Report,” 7, 9; Williams, "1969 Annual Report," 12.
} 
du Pont family materials in the original Longwood and Winterthur collections, the DuPont Company materials, as well as more generalized descriptions of the other manuscript collections accessioned through 1965. Numeric summations of the individual manuscripts items in each collection demonstrated Riggs' dependence on an item-level frame of reference. ${ }^{276}$

In 1964, the Publications Committee selected the University of Virginia Press to become its official partner for publication of books by the Eleutherian Mills-Hagley Foundation. Richmond Williams encouraged Library staff to participate in this program, because he felt that guides to collections (like Riggs'), edited reprints of rare volumes, and published bibliographies helped to publicize the Library's holdings. Cataloging librarian Evald Rink in 1981 produced a bibliography of early printing in the state of Delaware through the program and would subsequently produce the authoritative bibliography Technical Americana: A Checklist of Technical Publications Printed Before 1831. ${ }^{277}$

The Guide and books published by the University Press of Virginia were not the only mechanisms by which the Hagley sought to attract the attention of scholars. Although the October 1961 dedication opened the new library to the public, researchers were still expected to secure advance permission for access, with an application and review process, including approval from the Library Director himself. Williams, however, warned that high school students and college undergraduates would not ordinarily gain permission to use library facilities. Although a few items which were not considered rare were shared through interlibrary loan, books would not "ordinarily circulate to residents in the Wilmington area." 278

To encourage scholars to see the Hagley as a resource, the Library began a "Grants in Aid" program in 1962, helping to defray costs of a stay in the Wilmington

\footnotetext{
${ }^{276}$ Williams, "1970 Annual Report,” 8-9; and Riggs, Guide (1970), xix.

277 Williams, "1964 Report," 2; Williams to Hagley Library Departments Heads, "The Library Role in an Overall Foundation Publication Program" (“draft”), October 8, 1963, Box 364, Folder "Policy," EMHFA/RG5; Rink, Printing in Delaware, 1761-1800; Technical Americana: A Checklist of Technical Publications Printed Before 1831 (Millwood, N.Y: Kraus International Publications, 1981); and Williams, "1975 Annual Report," 13.

${ }^{278}$ David, “The Longwood Library - It's Scope and Purpose,” 1960, 20-21.
} 
area. Administered by the newly-formed joint Research Committee, the grants provided up to $\$ 500$ to each scholar per month, with the length of the grant dependent upon the project. Selection was based primarily on the "usefulness of the total resources of the Library to the applicant's project" and the significance of the scholar's work to their general field of study. Preference was given to people who planned immediate publication of their research with the hope that references to Hagley's collections in prefaces and footnotes might attract other scholars. Initially intended for postdoctoral researchers, the program was broadened in 1969 to include those in the research stage of their dissertations. The first round of recipients included Stephen Ambrose, who was gathering source material for a biography of U.S. Army general and military strategist Emory Upton. ${ }^{279}$

Another important group of researchers encouraged to use the Hagley were select graduate students from the History Department at the University of Delaware. That department had, working with the Hagley Museum, developed a program in 1954 that supported doctoral students (and later master's students), known as "Hagley Fellows," who were studying the history of business, industry, and technology. ${ }^{280}$

Research and reference activities in the new library escalated quickly, particularly due to the presence of Hagley museum research staff housed in the building and the presence of the Hagley Fellows. Friction emerged between the Library staff and the Hagley Fellows. Conceptually, the fellowship program was predicated on immersion in archival resources from which research would arise. In the pre-merger library at the Hagley Museum, this equated to direct access to the stacks and immediate access to manuscript acquisitions as they arrived. While Library staff believed that "it is a privilege

\footnotetext{
279 Williams, "Preliminary Draft," 1973, 8; Williams, "1962 Report,” 3; Williams, "1969 Annual Report," 3, Box 169, Folder "Annual Reports-Library, 1960-1967," EMHFA/RG5. Quoted section about selection criteria is from the announcement of the grants program in "The Editor's Corner," Business History Review 36:2 (Summer 1962) 229-230.

${ }^{280}$ The 1954 establishment of the Hagley Fellows program was confirmed through personal e-mail communication with Dr. Arwen Mohun, professor and chair of the Department of History at the University of Delaware, March 11, 2017. The department holds an unfinished manuscript detailing the history of the program which references 1954 correspondence between Walter Heacock and John Munroe. See also Williams, "1975 Annual Report,” 4, Box 169, Folder "Annual Reports - Library, 19601967," EMHFA/RG5; and Walter Heacock to Charles David, April 7, 1958.
} 
in research libraries to open stacks to serious scholars," they felt the need to exert some level of control over the collections and their use. At Longwood, stack access had been restricted and regulated, including sign-in logs, call slips to document use of specific collections, and other registration routines. John Riggs now faced pressure by members of the Hagley Fellows program for access to the Longwood papers as he was attempting to catalog them. He encouraged "these Hagley people" to exhaust all of other sources first. Following the merger, it quickly became necessary to segregate and close the manuscript materials. ${ }^{281}$

Yet another way the merged Library sought to promote itself was through an exhibit program initiated to showcase manuscript and imprint titles from the collections. Exhibits included "Local Industry in the National Perspective, 1789-1833," "1962 Acquisitions in the Industrial Manuscripts Collections," and "Technology at the Centennial Exposition at Philadelphia of 1876." The new Library also began to host to a variety of meetings and conferences to introduce communities of historians, archivists, and librarians to the collections. Hagley hosted, among others, the Delaware Library Association, the Philadelphia Chapter of the Association of College and Research Libraries, the Philadelphia Special Library Council, and various smaller regional antiquarian book and historical societies. ${ }^{282}$

While the Hagley Library, in the aftermath of the consolidation, undertook programs to promote staff professional development and attract the attention of scholars, the most important development in the period 1961-1982 was the rapid expansion of its non-DuPont manuscript collections. While affirming that the du Pont name would continue as a "central core" of the library, Richmond Williams realized there were diminishing returns because fewer and fewer additional du Pont items would be uncovered. Although his vision for a national scope of collections failed to receive institutional support, he felt that even a Mid-Atlantic or Delaware Valley industrial

\footnotetext{
${ }^{281}$ Williams, "1961 Report," 4; "Minutes,” Longwood Library staff meeting, October 17, 1961, 1; November 24, 1959, 3;/ and October 17, 1961, 3.

${ }^{282}$ Williams, "1962 Report," 3-5; Williams, "1963 Report," 1, 4; Williams, "1970 Annual Report,” 10, Box 169, Folder “Annual Reports - Library, 1960-1967,” EMHFA/RG5.
} 
archives would provide room for important expansion of Hagley's industrial manuscript collections. ${ }^{283}$

Debate about geographic collecting boundaries repeatedly resurfaced. Only four months into his employment, Richmond Williams presented a plan to acquire records from active anthracite coal companies in the Scranton, Wilkes-Barre area, with the idea of "making E.M.H.L. the center for study of the coal industry of that region." Williams was familiar with that region's history and historical records, having been director of the Wyoming Historical and Geological Society in Wilkes-Barre. Charles David and John Riggs, however, felt the topical area was "too far afield" since the anthracite coal region was centered nearly 150 miles north of Wilmington. ${ }^{284}$

Although Williams' proposal did not receive support, it renewed conversation about seeking financial support for records from active corporations. Hagley staff turned again to their experienced colleagues at Harvard's Baker Library. In cases where materials were taken on deposit, Baker included a clause on their deposit form indicating that materials would become Baker's property after twenty years. Robert Lovett at Baker Library cautioned against accepting too many restrictions from depositors concerning access or use. "If restrictions are kept as simple and made as definite as possible," he wrote, "I do not see why deposits should not be accepted." "If one cannot get a collection any other way than on deposit, then I guess one just has to go along with the wishes of the donor."285

Following Baker's example, Hagley developed a standard deposit agreement for the archives of active companies - and many subsequent collections arrived through deposit agreements, rather than outright gifts. Some of the negotiations were styled more like a business sales pitch: "we borrow, list, service, and store your archives in a

283 "Collecting Policy of E.M.H.L - June 1971” (“draft”), Box 362, Folder "Collecting Policy," EMHFA/RG5.

${ }^{284}$ Quoted sections are from "Minutes," Longwood Library staff meeting, September 15, 1961, 5.

${ }^{285}$ Quoted sections are from correspondence between Charles David and Robert Lovett, November 27 and November 30, 1956, Box 145, Folder "Business History-Lukens Steel Company," EMHFA/RG4. This folder also includes a sample of the "Memorandum of Manuscript Acquisition" donor form used at Baker Library during this period. See also "Minutes," Longwood Library staff meeting, September 15, 1961, 5, and November 7, 1961, 3. 
fireproof, humidity-controlled library." Hagley committed its resources to store, organize, and inventory the materials with "the same care and protection accorded to its own collections." Proprietary records could be closed for a period from the time of creation, files with information about living individuals would be handled sensitively, and further restrictions could be applied by the company. Hagley invested considerable staff time in maintaining and updating a "Restrictions Book" that recorded the various controls required by donors. In some cases, for instance, a scholar might need to secure written permission from the donor to access certain records or to publish quotations. Deposits were taken for a period of twenty years, with the opportunity at that point for either party to discontinue the arrangement. The costs for any special preservation or repair work with the materials would be borne by the company. ${ }^{286}$

John Riggs was adamant that the owners must "foot the bill" for work after the transfer based on his past experiences. The original letters of Admiral du Pont, for example, had been glued into scrapbooks by a well-meaning du Pont family member, sometimes obscuring the text of the letters themselves. Longwood staff worked with conservators at the Delaware State Archives to dismount them, remove the glue and other defacements, and dry them. It was slow work that took more than four months and even involved training some Longwood guards to do the work. Records from Lukens Steel, likewise, arrived in bad physical state, damaged from years of misuse and poor storage conditions. Riggs restricted such records from public use until proper cleaning, conservation, processing and rehousing were completed, requiring considerable work. ${ }^{287}$

${ }^{286}$ Quoted section about "fireproof, humidity-controlled library" is from the draft letter, Richmond Williams to Western Savings Fund Society, February 28, 1973, 1, Box 373, Folder "Acquisition Policy," EMHFA/RG5. Quoted section about "care and protection" is from the EMHL deposit agreement dated February 27, 1973, is from Box 373, Folder "Acquisition Policy," EMHFA/RG5. Williams felt Hagley and active corporations - needed to aspire to larger philosophical goals and consider the deposit of archival materials as a responsible act for the public good. In his draft letter to the Western Savings Fund Society, he indicated they would be "adding to the fund of knowledge of historians who might study the development of the American free enterprise system." In addition, the preservation of such records in a public research facility would indicate the importance of a company to this national story, and allow the company to present itself as a reputable firm with "nothing to hide from the objective research scholar." See also David, "The Longwood Library - It's Scope and Purpose," 1960, 8; and Riggs, Guide (1970), xxi.

${ }^{287}$ David, "Brief Progress Report," 1957, 1; “Minutes," Longwood Library staff meeting, September 15, 1961, 5, and November 7, 1961, 3. 
While the steps that Williams took to improve the administration of Hagley and promote its image were important, his most significant accomplishment was expanding Hagley's non-DuPont collections. Williams may even have taken advantage of Riggs' distraction with preparing and publishing the Guide to implement several mechanisms to expand the Library's non-DuPont collections. "Perhaps the greatest shift from the Longwood experience was the concentration on business and industrial archives," he reflected later in his career. "These gradually replaced first in size and later importance" the collections of private papers acquired through the du Pont family."288

The single most important step in doing this was Williams' creation in 1962 of a wholly new staff position specifically dedicated to seeking and acquiring industrial manuscript records. The "Specialist in Industrial Collections" position (or "SIC" as it came be known) reported directly to Williams, rather than the manuscript curator, Riggs. Two individuals provided significant leadership in this role during the rapid expansion of Hagley's industrial manuscript collections: David Gilchrist, 1962-1966, and Hugh Gibb, 1969-1979. A doctoral student at Johns Hopkins, Gilchrist began as SIC on July 9, 1962, and was promoted to Assistant to the Director in 1964 in recognition of the many special projects he worked on in addition to acquisition of industrial manuscripts. When Gilchrist became director of publications at Hagley in February 1967, Dr. Daniel Nelson briefly filled the SIC position, though he quickly moved up to Fellowship Coordinator for the Foundation. His successor, Hugh Gibb, brought over thirty years of interest in railroad history, culminating in his 1965 master's degree from the Hagley program examining the history of the Delaware Railroad. Gibb became SIC in 1969 and remained until his retirement in 1979, though he would return in 1983 as a volunteer on a project to organize the Reading Railroad records. ${ }^{289}$

\footnotetext{
${ }^{288}$ Williams, “1967 Report,” 4; and Williams, "Preliminary Draft,” 1973, 6.

${ }^{289}$ Williams, "1962 Report," 9; David Gilchrist to Richmond Williams, "Report of the Activities of the Specialist in Industrial Collections for the year 1963," 1, Box 169, Folder "Annual Reports-Library, 1960-1967," EMHFA/RG5 (hereafter Gilchrist, "Report-1963”). Gilchrist's 2011 obituary indicates that he "attended the doctoral program in history at Johns Hopkins University," and there are references to a trip to the Huntington Library in 1964 "pursuing his own research for his doctoral dissertation. A search of the Johns Hopkins library catalog failed to discover a dissertation. See "David Gilchrist," The Day (New London, Conn.), September 9, 2011, http://www.legacy.com/obituaries/theday/obituary.aspx?pid=153522898 accessed October 13, 2015.
} 
The first person to hold the position, David Gilchrist, set himself three initial tasks: define a collection policy and methods, deal with existing collections and pending acquisitions, and plan for the expansion and use of the collections. The SICs encountered little competition from other repositories for "industrial” collections. "The library's general field of interest," Gilchrist noted in 1962, "does not now appear to be broadly populated by institutions making similar efforts to collect the resources of business history." 290

With the charge to significantly expand the Hagley's industrial manuscript holdings, the SICs developed a number of tools. The first was a "lead card" system that Gilchrist designed to track information about potential new manuscript acquisitions. These cards also helped him to interact internally with staff to reestablish contact with some donors when negotiations had lapsed. Gilchrist also developed a second file with the names of companies and individual businessmen who had been active in the region. This "regional reference list of business and businessmen" helped in locating and evaluating new acquisitions. ${ }^{291}$

David Gilchrist to Richmond Williams, "Report of the Activities of the Specialist for the year 1964," 5 , Box 169, Folder "Annual Reports-Library, 1960-1967," EMHFA/RG5 (hereafter Gilchrist, "Report1964"); Williams, "1964 Report," 4; Williams, "1966 Report," 8; Williams, "1967 Report," 5; Hugh Gibb to Richmond Williams, "1969 Annual Report," January 12, 1970, 1, Box 373, Folder "Annual Reports - Industrial Specialist," EMHFA/RG5; David Gilchrist to Richmond Williams, "Report of the Activities of the Specialist for the year 1966," 1, Box 169, Folder "Annual Reports-Library, 1960-1967," EMHFA/RG5 (hereafter Gilchrist, "Report-1966"); Hugh Gibb, The Delaware Railroad (M.A., University of Delaware, 1965). Additional biographical information about Gibb is from Duane Swanson and Hugh Gibb, The Historical Records of the Components of Conrail: A Survey and Inventory (Greenville, Del.: Eleutherian Mills Historical Library, 1978), 4; Williams, "1969 Annual Report," 7; Williams, "1969 Annual Report," 7; Michael Nash, "1983 Annual Report - Manuscripts and Archives Department," 7, Box 365, Folder “Annual Reports, 1956-1986," EMHFA/RG5.

${ }^{290}$ Quoted section is from David Gilchrist to Richmond Williams, "Report of the Activities of the Specialist for the Period July 9, 1962 to December 31, 1962," 6-7, Box 169, Folder "Annual ReportsLibrary, 1960-1967," EMHFA/RG5 (hereafter Gilchrist, "Report-1962"). See also Gilchrist, "Report$1963, " 1$.

${ }^{291}$ Gilchrist felt that any success he might have as SIC would come from the existing network of contacts at Hagley, so he distributed cards to members of the library and museum staff. The 5" x 8 " cards held information about private collections and items held by booksellers and auction houses, and had space to maintain a chronological record of contact by any staff member. Gilchrist organized the cards topically, helping him to think thematically about current collections and future additions. Williams, "1962 Report," 9; Gilchrist, "Report-1966," 9; Gilchrist, "Report-1962," 1-2, 7; Gilchrist, "Report-1963," 5. 
Over time, the Specialists in Industrial Collections created subject bibliographies of imprint materials relating to the region's business history. The bibliographies also helped identify key companies to approach for business records and informed Hagley's ongoing acquisitions of print and microformat copies of journals, research literature, and the proceedings of industrial and business associations. For instance, Gilchrist compiled bibliographies of French travelers' accounts of American economic conditions (particularly those who visited the Philadelphia-Wilmington area), of periodicals and secondary literature about the railroad industry, of canal development in the region, and of literature on scientific management. Gilchrist's system of identifying appropriate new imprint titles for purchase was so successful that it became difficult later to find older materials not already in the library's possession."292

Gilchrist, working with Hagley Fellow James Stokesberry, also developed a "Regional Catalog of Source Materials in Business History" to better describe and encourage access to business and industrial manuscript records it and other repositories in the region held. Their initial survey identified nearly 180 institutions with manuscript collections “pertinent to this Foundation's interest in American economic and technological history." Conversations with the Library of Congress helped design field forms and processes so that the results of the work could be included in the National Union Catalog of Manuscript Collections. An initial pilot project in the summer of 1964 included visits to ten selected repositories, including the Delaware State Archives, the Historical Society of Delaware, and the county historical societies in Chester and Bucks County. The work continued for several years under both Gilchrist and Gibb, with more than 3,700 collections identified at 120 repositories. Gibb portrayed it as an additional service to the research community: "If we don't have it, we know where it is."293

\footnotetext{
292 The guides indicated which titles were already held by the library and which could be added to the "want list" of the Acquisitions Department to guide purchases from dealers' catalogs. Gilchrist and other Hagley staff maintained close contact with booksellers throughout the region, informing them of the library's thematic interests and encouraging them to offer material in advance of inclusion in their distributed catalogs. As a result, the library was often able to purchase books before they were offered for public sale, see Gilchrist, "Report-1962," 6; Gilchrist, "Report-1963," 1; Williams, "1963 Report,” 3; Gilchrist "Report-1964,” 1.

293 Quoted section about "pertinent” collections is from Williams, "Preliminary Draft," 1973, 11. Quoted section about "we know where it is" is from Hugh Gibb, notes for presentation (likely 1970), 5, Box 373,
} 
The project was invaluable in helping Richmond Williams and the SICs to better understand what had already been collected - and where Hagley might best direct its future collecting activity. Hugh Gibb, for instance, noted that many so-called "business collections" consisted mainly of bound accounting ledgers, and he was disappointed by how little information had been collected about regional technologies. "Companies which had no hesitation in committing their most intimate financial dealings to paper," he noted, "were more reticent about trade secrets." The project also encouraged several collecting projects, such as Gibb's manuscript acquisitions in the food processing industry in southern New Jersey in 1973. ${ }^{294}$

During Daniel Nelson's brief stint as Specialist in Industrial Collections, he helped to write a policy statement for collecting industrial manuscripts, which was approved in December 1967. The policy defined the geographic collecting area as the "mid-Atlantic states region" within an eighty-mile radius of Wilmington. From this work, Nelson designed a brochure to be used to "attract business manuscripts from the Wilmington area and beyond." The document provided an overview of the Eleutherian Mills Historical Library (as it was called then), the types of manuscripts sought, and the services and benefits provided to companies who deposited records. Nelson also compiled a list of nearly forty business firms in the Wilmington area that were more than 75 years of age to receive the brochure and a follow-up contact. The project expanded the network of businesses and business men in the region initiated by Charles David and resulted in Hagley acquiring records from several companies, such as the Wilmington Savings Fund Society (70 linear feet, 1831-1964), New Castle Mutual Insurance

Folder “Annual Reports - Industrial Specialist,” EMHFA/RG5. See also Williams, “1965 Report,” 6; Gilchrist "Report-1964," 4-5; Hugh Gibb to Richmond Williams, "1968 Annual Report," January 10, 1969, 1, Box 373, Folder “Annual Reports - Industrial Specialist,” EMHFA/RG5; Hugh Gibb to Richmond Williams, “1970 Annual Report,” January 18, 1971, 2, Box 373, Folder “Annual Reports Industrial Specialist," EMHFA/RG5; Hugh Gibb, "Research Possibilities in Middle Atlantic Regional Technology before 1900," Eleutherian Mills Historical Library Fall Regional Conference, October 31, 1969, 1, Box 373, Folder “Annual Reports - Industrial Specialist,” EMHFA/RG5; Williams, “1969 Annual Report," 12.

${ }^{294}$ Quoted section about "trade secrets" is from Gibb, "Research Possibilities," 1969, 1. See also Hugh Gibb to Richmond Williams, “1973 Annual Report,” January 16, 1974, 3, Box 373, Folder “Annual Reports - Industrial Specialist,” EMHFA/RG5. 
Company (2.2 linear feet, 1828-1962), Garrett, Miller \& Co. (12 volumes, 1896-1899), and George Hardcastle and Sons (3 volumes, 1892-1907). ${ }^{295}$

The SICs visited and maintained contacts with other institutions. For instance, in 1962, David Gilchrist and Evald Rink visited the Library of the Bureau of Railway Economics to inquire about their policies and procedures for cataloging, shelving, and acquisitions. From their visit, they submitted a report to Richmond Williams with recommendations for a Hagley collecting policy specifically for railroad material. Gilchrist visited a variety of other libraries, including the Franklin Institute, the American Antiquarian Society, the Library Company of Philadelphia, the Transportation Center at Northwestern University, the Chicago Historical Society, and the Newberry Library in Chicago, which Gilchrist felt stood out as similar in many ways to Hagley. ${ }^{296}$

In September 1962, Gilchrist visited with Robert Lovett at Baker Library. Although Hagley staff were already familiar with these collections, Gilchrist felt that "a trip to Baker Library is a necessary part of the education of anyone interested in business manuscripts as much of the pioneering work in the field was done there." Lovett shared a bibliography on records management principles he found useful when working with operating companies. He also offered several cautions to Gilchrist:

The great bulk of business records dictates caution in collection policy and emphasizes a need to collect quality rather than quantity. At the Baker Library space is at a premium and control of its collections has only recently been achieved. A vigorous collection program before World War II deluged the library with material more rapidly than it could be organized for use. It is apparent, however, that a library like the EMHL can perform a useful service by locating sources of business history which it [Baker] may not, for reasons of space and potential use, wish to acquire. ${ }^{297}$

\footnotetext{
${ }^{295}$ Quoted section about hope to "attract business manuscripts" is from Williams, "1967 Report," 7-8. A draft of the text for this brochure and the list of Wilmington businesses is included with "Statement of Manuscript Collecting Policies and Procedures," December 1, 1967, Box 373, Folder “Acquisition Policy," EMHFA/RG5.

${ }^{296}$ Gilchrist, "Report-1962," 6; Williams, "1962 Report,” 9; Gilchrist, "Report-1963,” 4.

${ }^{297}$ Gilchrist, "Report-1962," 2.
} 
Lovett also shared a large folder describing manuscript collections offered to Baker Library "but refused for various reasons." 298

While the SICs participated in a range of library and archival conferences, they were just as likely to attend gatherings of business records managers and business historians. A short list of Gilchrist's and Gibb's travel included the annual Business History conference, the American Historical Association, and a variety of special conferences on records management. Hugh Gibb arranged for Hagley to have booths in the vendor halls at the American Records Management Association conference and the Delaware Business Show, using the gatherings to talk about the importance of preserving company records and making them available for research - ideally at the Eleutherian Mills Hagley Library. "I will feel that we will have achieved success only when the commercial-industrial world automatically thinks of EMHL as the repository for its early records" (emphasis his). ${ }^{299}$

At the conferences they attended - and similar talks to staff at smaller museums Hagley staff stressed the importance of manuscript business records to understanding and interpreting industrial history. Archival records would "aid in the interpretation, reconstruction, maintenance, and operation" of machinery. Inbound and outgoing administrative correspondence, trade catalogs, and accounting records can help to understand the reasons specific equipment was purchased, the work it was put toward, and even whether the financial position of the company affected the choice of a "merely adequate machine or a first-class one."

Williams and the SICs coordinated a series of professional conferences at Hagley in the 1960s and 1970s, exploring themes relating to their manuscript collections. They invited scholars whose papers which might warrant publication, but might also alert scholars to the collections at Hagley and encourage staff to better understand Hagley's

\footnotetext{
${ }^{298}$ Gilchrist, "Report-1962," 2.

${ }^{299}$ Quoted section is from Hugh Gibb to Richmond Williams, August 29, 1969, "Aims of the Specialist in Industrial Collections," Box 373, Folder “Annual Reports - Industrial Specialist,” EMHFA/RG5. See also Hugh Gibb to Richmond Williams, "1974 Annual Report," January 17, 1975, 2, Box 373, Folder "Annual Reports - Industrial Specialist," EMHFA/RG5.

300 "Manuscript Collecting for the Non-Specialist," Box 373, Folder “Acquisition Policy," EMHFA/RG5.
} 
areas of collecting activity. The first conference, held in March 1964, examined the impact of the Civil War, with 75 scholar participants. Gilchrist co-edited a print volume of the proceedings distributed for free to libraries and archives around the world and used by several universities in economic history classes. A semiannual Hagley economic history conference eventually emerged, examining regional themes. From conference planning activities, Hagley eventually developed a mailing list of nearly 600 scholars interested in the fields covered by the library's collections. Hugh Gibb ultimately complained that the time he spent transcribing the proceedings, while promoting Hagley, only indirectly assisted his work of expanding the collections. ${ }^{301}$

As far as the SICs' actual work in collecting manuscripts, internal documents suggest an early understanding that collections would concentrate on the mid-Atlantic region in the years 1825-1925 with a particular focus on the nineteenth century, but with recognition of the need for some flexibility. ${ }^{302}$

[We] are interested all kinds of industrial, commercial, financial, and agricultural enterprises, both the records of the firms themselves, and of individuals who influenced their policies. Again, with a view to the physical limitations, we have stressed diversification rather than specialization ... The collecting policy has never been inflexible. We are endeavoring to expand its horizons with the qualitative taking precedence over the quantitative. $^{303}$

\footnotetext{
${ }^{301}$ Williams, "Preliminary Draft,” 1973, 7-8; Gilchrist, "Report-1963," 3; Gilchrist, "Report-1963,” 3-4; Williams, "1964 Report," 3; Williams, "Preliminary Draft," 1973, 7; David Lewis and David Gilchrist, Economic Change in the Civil War Era: Proceedings of a Conference on American Economic Institutional Change, 1850-1873, and the Impact of the Civil War, held March 12-14, 1964, (Greenville, Del.: Eleutherian Mills-Hagley Foundation, 1965); Gilchrist “Report-1964," 6; Gilchrist, "Report-1966," 1; Williams, "1969 Annual Report," 9; Williams, "1970 Annual Report," 9; Hugh Gibb to Richmond Williams, “1972 Annual Report,” January 15, 1973, 2-3, Box 373, Folder “Annual Reports - Industrial Specialist," EMHFA/RG5; Harold Williamson, editor, Evolution of International Management Structures (Newark: University of Delaware Press, 1975); Gilchrist, "Report-1963,” 1; Williams, “1963 Report,” 7; Gilchrist, "Report-1963,” 5; Gilchrist "Report-1964," 4.

302 "Statement of Policy for the Collecting of Industrial Manuscripts," (likely Daniel Nelson, 1968), Box 373, Folder "Acquisition Policy," EMHFA/RG5; Richmond Williams, "Goals for Acquiring Future Manuscript Collections," October 6, 1966, Box 362, Folder “Collecting Policy,” EMHFA/RG5.

303 Nelson "Statement of Policy," 1968.
} 
But the SICs, like David, soon found that "The field of business history is so vast and the materials so abundant - particularly on this side of World War I - that one has to exercise very great self-restraint or run grave risk of being overwhelmed."304

Publicly, Hagley's directors continued to emphasize that, geographically, collections would extend "not more than 80 air miles distant from the library," making the library the midpoint of a "Trenton-Philadelphia-Wilmington-Baltimore industrial axis" that included the steel and canal region around Bethlehem, Allentown, and Easton, Pennsylvania, as well as the Harrisburg/Hershey, Pennsylvania, metropolitan area, and much of the New Jersey coastline. In actuality, staff were willing to consider materials from a larger area. Some documents indicate a willingness to include anything south of Wilmington on the Delmarva Peninsula. And corporate structures at times required a more expansive approach. "Many organizations have their headquarters within our area but their operations extend far beyond our boundaries."305

To attain "a complete technological background," staff regularly reached outside the eighty-mile area. A good example is Hagley's desire to represent steam boiler manufacture in its collections. The ideal Wilmington enterprise would have been the Edgemoor Iron Company, but their records had not survived. One of Richmond Williams' contacts with the National Association of Manufacturers alerted him to records of a similar firm, the Erie City Iron Works (14 linear feet, 1864-1937). Hugh Gibb traveled the 400 miles to Erie, Pennsylvania, to collect the records in October 1966. “Although somewhat beyond the Library's geographic area," Gibb wrote in his annual report, the collection allowed them to represent the work which would have been done in Hagley's region by a company similar to Edgemoor. By 1978, Gibb and Williams acknowledged, at least internally, that they were not constrained by the eighty-mile rule.

\footnotetext{
${ }^{304}$ Charles David to David Roswell, May 14, 1958, Box 159, Folder “Miscellaneous Subjects,” EMHFA/RG4.

305 Quoted section about the Philadelphia-Wilmington-Baltimore axis" is from Gibb, notes for presentation, 1970, 1; Nelson "Statement of Policy," 1968. Closing quoted section is from "Statement of Policy for the Collecting of Industrial Manuscripts,” (1968), 1. See also Gibb, “1975 Annual Report,” 1.
} 
"If a collection has relevance to other holdings or can complement those holdings," Gibb wrote in an internal memo to Williams, "the geographic limitation is waived." 306

Yet, like Baker Library, Hagley sought to avoid over-collection in any one sector. Williams noted: "We should avoid the multiplication of records from the same type of company unless these duplicate records add significantly to the research value of those presently in our collections." "Two banks should be sufficient," Gibb wrote to Williams in 1969, and "we don't need any more grist mills." He felt Hagley had good coverage in the iron and steel industries, but lacked collections about the extractive industries supporting them, as well as the transportation networks connecting mines to mills and manufacturing facilities. "It may be necessary to go beyond our present geographic limits to achieve the balance, but they are flexible enough to stand the strain."307

The work of Gilchrist, Nelson, and Gibb expanded the non-DuPont manuscripts in the Hagley dramatically between 1962 and 1979. In most cases, collections were taken on deposit from active corporations or given as outright gifts by private owners. In rare cases, however, Hagley purchased materials from dealers. ${ }^{308}$

One early success was acquisition of the records of the Sun Oil Company (450 linear feet, 1908-1922). They included records of the Pew family, as well as materials from the Marcus Hook Refinery. That same year saw the acquisition of historical materials from dye manufacturer Carter \& Scattergood (0.8 linear feet, 1826-1903) and textile printing company, Eddystone Manufacturing Company (11 linear feet, 18771959). These were followed by records of leather firm J.E. Rhoads \& Sons (213 linear feet, 1699-1969) and the first of several accessions from the cloth spinning and weaving enterprise Joseph Bancroft \& Sons (with subsequent additions, the combined accessions now comprise more than 500 linear feet, covering 1831-1974). Williams described the

\footnotetext{
${ }^{306}$ Nelson "Statement of Policy," 1968; Gilchrist, "Report-1966," 4-5; Hugh Gibb to Richmond Williams, "Job Description - Specialist in Industrial Collections," 31 August, 1978, 1, Box 373, Folder "Annual Reports - Industrial Specialist," EMHFA/RG5.

${ }^{307}$ Williams, "Goals," 1966; Gibb "Aims of the Specialist in Industrial Collections" 1969, 1.

${ }^{308}$ See Gilchrist's comments on the purchase of the "fairly extensive" collection of mercantile records from a Philadelphia dealer, Gilchrist "Report-1964," 3.
} 
Bancroft collection as rivaling the DuPont Company records in extent and completeness. $^{309}$

The range of industries expanded over time. The personal papers of engineer Frederick W. Wood (13.25 linear feet, 1867-1943) included photographs and blueprints relating to the Pennsylvania Steel Company, the Maryland Steel Company, and the Hogg Island Shipyard. The Philadelphia Suburban Transportation Company (147 linear feet, 1792-1973) and the Red Arrow Lines Photograph Collection (3.5 linear feet, 1899-1970) documented the interurban railway network in the greater Wilmington area. Materials from Dowling \& Kennedy (5.0 linear feet, 1872-1886) documented a railroad contractor's work with the Lackawanna Railroad in the 1880s. Although the records of the Fitz Water Wheel Company (285 linear feet, 1897-1966) did not include accounting records or measured drawings, the truckload of material the Library acquired included purchase orders, contracts, and correspondence - as well as manufacturing records such as shop orders and shop cost-accounting ledgers. ${ }^{310}$

Williams and the SICs weren't only interested in large industrial enterprises. Smaller acquisitions included records of several early nineteenth-century mercantile houses, such as Wilmington-based Dutilh \& Wachsmuth (5.0 linear feet, 1772-1875) and a small collection from Edith McConnell (3 volumes, 1937-1956), who operated a restaurant and bake shop frequented by Hagley's senior staff. Interest also extended beyond the records of business enterprises to the personal papers of specific individuals. During a vacation to Ireland, Hugh Gibb examined and arranged to microfilm the diaries of Richard B. Osborne (one microfilm reel containing seven volumes, 1829-1857), an Irish engineer involved in the construction of the Camden and Atlantic Railroad, which opened up the Jersey shoreline for the development of Atlantic City. ${ }^{311}$

In some cases, the Specialists in Industrial Collections were able to collect both manuscripts and printed material. While negotiating for the records of the Phoenix Steel

\footnotetext{
${ }^{309}$ Williams, "1962 Report," 9; Gilchrist, "Report-1962," 5; Nash, "Business History at the Hagley Museum," 110; Gilchrist, "Report-1963," 2; Gilchrist "Report-1964," 2-3; Williams, "1965 Report," 1; Asher, "Researching," 763-764.

${ }^{310}$ Gibb, "1975 Annual Report," 1-3; Gilchrist, "Report-1966," 3-4.

${ }^{311}$ Gilchrist "Report-1964," 3; Gibb, notes for presentation, 1970, 1; Gibb, "1975 Annual Report," 3.
} 
Company, for instance, David Gilchrist identified and later purchased from the company a collection of nearly 500 books and pamphlets, including long runs of the Railroad Gazette, Engineering News, Engineering Record, and the Engineering-News Record. In other cases, contacts made for printed materials led to the discovery and donation of manuscript items. In 1966, Gilchrist learned the corporate library of the Pennsylvania Railroad was distributing some of its books to interested libraries. Working through Lammot Copeland, he managed to secure a gift of published annual reports for railroads in the Pennsylvania family. The contact introduced Hagley as a serious professional industrial library - a connection that would come full circle years later when Hagley acquired manuscript records from the parent company. ${ }^{312}$

The SIC also collaborated with colleagues in Hagley's pictorial collections unit to acquire a collection of nearly 27,000 glass plate negatives and 34,000 prints from the Westinghouse Steam Division (201 linear feet, 1898-1964), including extensive documentation of not only turbine and generator manufacture, but also images of workers and communities for the period covering 1910-1940. ${ }^{313}$

The Phoenix Steel Company (77.3 linear feet, 1827-1963) collection reflects the challenges Hagley faced with industrial records. Initial negotiations stretched out over two years, resulting in an initial transfer of two truckloads of materials from Phoenixville, Pennsylvania (about thirty miles north of Wilmington), in 1966. The donation included the larger collection of records of the Phoenix Bridge Company (220.4 linear feet, 18741963), a subsidiary that operated from the 1860s to the 1960s. In terms of sheer bulk, nothing Hagley had dealt with previously approached the collection of measured drawings acquired from the bridge company: nearly 2200 contracts and more than 25,000 individual prints. Richmond Williams had to pay to have the Phoenix blueprints placed in a secure offsite public storage facility from which they were processed and retrieved for

\footnotetext{
${ }^{312}$ Gilchrist, "Report-1966," 5.

${ }^{313}$ Memorandum, Hugh Gibb to Richmond Williams, "1969 Annual Report," January 12, 1970, 1; See also Richmond Williams, "1969 Report," 8.
} 
research use. The initial processing and inventorying took up an extensive amount of Hugh Gibb's time, and the corporation continued to deposit more records with Hagley. ${ }^{314}$

The SIC's also helped shepherd the ongoing relationship with the DuPont Company. Annual reports from the period include references to transfers from the Advertising Department, Brandywine research laboratories, and early corporate records. The 1978 supplement to the Guide, which covered accessions from 1966 to 1975, indicates additions to the E.I. du Pont de Nemours \& Company records included approximately 46 linear feet added to the existing Series I and more than 250 linear feet added as a wholly new Series II. The new series included 82 separate accessions touching all aspects of the Company's business, with many document sets extending through the end of World War II and some even reaching into the 1960s and 1970s. Yet the DuPont Company remained conservative in the amount of post-1915 material it transferred to Hagley's publicly-accessible collections. Richmond Williams worked diligently to get DuPont to free up more materials, but more than ten years of negotiations found the company holding to a policy which severely restricted the kinds of materials that could be donated. $^{315}$

The SICs, however, did succeed in bringing in several collections of personal papers relating to employees of the DuPont Company. In 1963, David Gilchrist negotiated acquisition of the papers of Treasurer John Raskob (300 linear feet, 19001956), claiming them to be the "most important acquisition" of the Library since Longwood received the Winterthur manuscripts. Like P.S. du Pont's papers, the Raskob papers presented access problems due a fifty-year restriction placed by his heirs.

Although Hagley continued to accept collections with restrictions, Williams attempted to allow scholarly access whenever possible. "All collections," he wrote, "have been given with the idea that they should be used for research by qualified scholars." Williams

\footnotetext{
${ }^{314}$ Gilchrist, "Report-1964," 2; Gilchrist, "Report-1966," 3-4; "Sometime in 1924 Phoenix had destroyed all drawings made prior to $1905 \ldots$ and subsequent filing had been careless to say the least," Gibb, "1971 Annual Report," 1; D.T. Muir, "What Constitutes Pictorial Collections?" April 25, 1972, Box 363, Folder "Operations of M\&A Department," EMHFA/RG5.

315 Williams, "1963 Report," 1-2; Gilchrist, "Report-1962,” 5; Gilchrist, "Report-1963," 1; Riggs, Guide: Supplement (1978); Williams, "1964 Report," 4; Williams, "1966 Report," 9; Williams, "1969 Annual Report,"13; and Williams, "1970 Annual Report," 4.
} 
judged access questions for closed collections on a case-by-case basis. It was challenging, however, to make equitable decisions. For instance, Williams provided access to Alfred Chandler and Stephen Salsbury for their authoritative biography of P.S. du Pont. But once their book was published, other scholars were denied access. ${ }^{316}$

Acquisition of the Atlas Powder Company records (104 linear feet, 1868-1958) were ostensibly a DuPont transfer as Atlas had been created in 1912 as part of the courtordered breakup of firms involved in an alleged explosives monopoly. "The removal of [Atlas] records from Reynolds, Pa. was my largest physical operation of the year," reported Hugh Gibb, "involving four days' time and 320 miles of travel for three persons." The collection included more than 700,000 items, not all of which they expected to keep permanently. Hagley's relationship with the DuPont Company included regular negotiations for physical space for storing and processing collections. As noncurrent company records made their way to Hagley's permanent collections, it freed up space in DuPont's Hall of Records. This, in turn, was made available to Hagley for temporary storage of bulky new acquisitions, such as the records of the Pennsylvania Bank and especially those of the Reading Railroad, acquired from the Pennsylvania Historical Society in 1975. "It must be recognized that [the acquisition of the Reading papers] would not have been possible without the cooperation of the DuPont Hall of Records," Hugh Gibb noted. "This collection could not have been housed on our premises and it would have been impractical to place it in public storage." ${ }^{317}$

Space and staff for processing collections became an increasing concern as Williams and the SICs succeeded in their work. When the new library facility opened in 1961, manuscript collections occupied a combined total of 2,600 linear feet - in a building designed to hold 10,000 linear feet of manuscript material. By the end of 1971, the library had 7,300 linear feet of manuscripts in-house with some larger collections held

\footnotetext{
${ }^{316}$ Quoted section is from Williams, "1963 Report," 1, 10. See also Gilchrist, "Report-1963,” 2; Williams, "1966 Report," 6; and Williams, "1965 Report," 3.

${ }^{317}$ Quoted section about removal of the Atlas records is from Gibb, “1975 Annual Report," 2. Gibbs' quoted section sharing appreciation to the DuPont Hall of Records is from Gibb "1974 Annual Report," 2. See also Williams, "1975 Annual Report," 4; Hugh Gibb to Richmond Williams, "1976 Annual Report," January 7, 1976, 1, Box 373, Folder “Annual Reports - Industrial Specialist,” EMHFA/RG5; Gibb, "1969 Report," 1; and Williams, "1969 Annual Report," 8.
} 
offsite. Hagley implemented plans to add shelving to the third floor of the stacks, but that filled quickly, too. Riggs noted in 1972: "[T]he Library feels the pinch of space in many areas. The manuscripts storage area is rapidly filling up with only a year or more of capacity left." There was also a growing issue in the reading room due to increasing numbers of visiting researchers, grants-in-aid recipients, and Hagley Fellows. ${ }^{318}$

John Riggs recommended the library simply rein in manuscript acquisition. "We have to realize that we cannot acquire and house everything that is extant or available." The SICs, however, continued to bring in new materials, and Williams continued to expand the use of commercial offsite storage. The Phoenix Steel records, additional collections from Joseph Bancroft \& Sons Licensing (2 collections totaling 70.5 linear feet, 1867-1971), and the Pennsylvania Power and Light papers (multiple collections totaling 1,000 linear feet, 1853-1957) were shunted to outside storage firms. A process evolved where incoming acquisitions would be stored temporarily in rented public space, moved to the Hall of Records for initial processing, and finally moved to the library to be shelved and made publicly available. Yet the minutes from staff meetings make regular reference (and complaint) about collections in offsite "dead storage" lacking any form of inventory control. And such storage was not inexpensive; Hugh Gibb reported combined costs of about $\$ 7,000$ in 1976 alone. $^{319}$

Not surprisingly, staff suggested a variety of plans, including an additional stacks building or records center. Removal of all manuscripts from the existing building, they argued, would allow for expansion of printed materials. By 1975, close to 50\% of Hagley's manuscript items resided at locations other than the main library. Conditions at these areas seldom met minimal environmental and fire standards, and there was the added cost of access and retrieval. For example, the records of the National Association

\footnotetext{
${ }^{318}$ Quoted section about "the pinch of space" is from Williams, "1970 Annual Report," 2. See also John Riggs to Richmond Williams, "Consideration on the subject of space in the present building and projection for the next twenty years," February 1972, 1, Box 362, Folder "Accessions," EMHFA/RG5; and Williams, "1967 Report," 10.

${ }^{319}$ Gibb, "1971 Annual Report," 1; Riggs "Consideration on the subject of space," 1972, 3; Gibb, "1972 Annual Report," 1; Williams, "1976 Annual Report." 4, 6, 10; Hugh Gibb to Richmond Williams, "1977 Annual Report," January 19, 1978, 1, Box 373, Folder “Annual Reports - Industrial Specialist," EMHFA/RG5; Michael Nash, John Rumm, and Craig Orr, Pennsylvania Power \& Light Company: A Guide to the Records (Wilmington, Delaware: Hagley Museum and Library, 1985).
} 
of Manufacturers (at that time more than 1,000 linear feet, 1895-1973) were housed more than three miles away. Staff frustrations continued to grow with the "relentless game of musical chairs." 320

The format and condition of incoming materials also posed challenges, leading to serious questions about appraisal and selection. Measured drawings and blueprints, for instance, posed both administrative and conservation questions. Some argued that blueprints were photographically produced and therefore should be in the Library's pictorial department, not the manuscript unit. Collections with large drawings couldn't be processed until a suitable storage areas and appropriate cabinetry were arranged. Finally, as with many other items coming from former industrial sites, drawings required specialized conservation treatments because most had been stored in unfavorable humidity conditions by their corporate creators. ${ }^{321}$

Questions also arose over what role the Specialist in Industrial Collections should have in processing collections. As originally designed, the SIC was a field archivist whose primary role was to seek and acquire collections, not process them. "There is not an Industrial Collections Department," complained the head of the Pictorial Division. Once the records were in house, processing was supposed to be done by the Imprints, Manuscripts, or Pictorial Collections Departments. The Research and Reference Department was then to provide access and support to scholars. But Riggs and the staff of the Manuscript Department were buried in the work of processing the Longwood and Winterthur manuscripts - and preparing the contents of the Guide. Processing lagged far behind acquisitions. The large influx of new acquisitions also created bottlenecks in Hagley's procedure for fumigation of incoming material. ${ }^{322}$

Gilchrist and Gibb both complained about the slow pace of manuscript processing in Riggs' unit. In a private memo to Richmond Williams, Gibb implied that the problem

\footnotetext{
${ }^{320}$ Closing quoted section is from Williams, "1975 Annual Report," 4. See also Riggs "Consideration on the subject of space," 1972, 3. Hagley continued to receive materials from the National Association of Manufacturers, whose collections by 1972 measured more than 1,200 linear feet.

${ }^{321}$ Muir, "What Constitutes Pictorial Collections?" 1972; Gibb, “1969 Report," 1.

${ }^{322}$ Quoted section is from Muir, "What Constitutes Pictorial Collections?" 1972. See also Gilchrist, "Report-1963," 2.
} 
lay with the women Riggs employed, indicating that they could not work as quickly as one "who knows the territory." Hugh Gibb ultimately struck a deal with Riggs to do a pilot processing project himself, albeit under the curator's direct supervision. His work with records from the Wilmington Savings Fund Society (70 linear feet, 1831-1964) proved his ability to process manuscript collections efficiently: ${ }^{323}$

We picked [the collection] up on Wednesday. I started midday on Thursday and was finished by 2 P.M. on Friday, doing the shelving entirely alone. By comparison, two of his girls required two weeks to shelve the Artisans collection which was somewhat smaller... I cannot see improvement in the near future with the present working force of that department. A considerable amount of my time for the next few months must be devoted to this area." 324

Williams had "reservations about this diffusion of effort" away from the primary acquisitions goals for the SIC, but Gibb felt strongly that helping with collections processing was critical to the success of the program. Regardless of how others thought things should work, Hugh Gibb characterized himself as "the one-man Industrial Collections Department" and boasted that his acquisitions and processing work made as much research material available in a single year as most institutions collected in a generation. ${ }^{325}$

To his credit, Hugh Gibb developed a working relationship with John Riggs. "The seemingly unbelievable thing to me is that he and I have achieved a rapport," he wrote to Williams. "I shall do my best to keep it that way." That said, both Gibb and Williams were concerned that processing work detracted from field and acquisitions work. Both felt that the larger part of Gibb's time, upwards of $65 \%$, should be directed to collecting, with only $20 \%$ spent working on processing/cataloging, and lesser amounts to research and other projects. In August 1978, however, Gibb calculated that only 20\% of his time was spent collecting and upwards of $70 \%$ spent processing collections. Williams had "reservations about this diffusion of effort" away from the primary acquisitions goals for

\footnotetext{
${ }^{323}$ Williams, "1967 Report," 4; Gibb "Aims of the Specialist in Industrial Collections" 1969, 1.

${ }^{324}$ Gibb "Aims of the Specialist in Industrial Collections" 1969, 1.

${ }^{325}$ Gibb, "1969 Report,” 1. Williams, "1976 Annual Report." 5-6.
} 
the SIC, but Gibb accepted the trade-off that his help with collections processing positively impacted scholarly access. ${ }^{326}$

Surviving records indicate some instances where Hagley failed to acquire a collection or declined materials. In addition to the anthracite coal records the Foundation board denied, David Gilchrist missed a donation of older records from the then-active Lehigh Coal and Navigation Company (204 cubic feet, 1792-1978) when the owners decided to donate them to the Pennsylvania State Archives (though Gilchrist groused about the use of public funds to preserve the records of private companies). Hagley wanted the papers of naval architect and marine surveyor H.H. Thayer to complement the papers of his father already in the collections. In the end, however, the owners decided to turn Thayer's papers over to the marine library at Mystic, Connecticut. ${ }^{327}$

In other cases, private owners or auction houses approached Hagley about the possible purchase of manuscript items. One example was a collection of records from Riehle Brothers of Philadelphia, a manufacturer of scales and scale testing equipment. The collection, which included eight cartons holding about 24,000 items, mostly bills and receipts, had research value in an area not otherwise represented at Hagley. But the lack of core administrative records such as minutes, executive correspondence, annual reports, or equipment inventories, did not support the seller's asking price of $\$ 15,000$. Richmond Williams ultimately declined purchase. "We are not interested in purchasing the collection at the asking price," he wrote to the owner. "I suspect that [the] best chance to reap a reward ... would be more indirect - to get the collection appraised and to give it to a non-profit, tax exempt institution like ours.” Another agent offered Hagley records from Joseph Shipley, a leading Anglo-American merchant banker in the early nineteenth century. Staff were able to discern the likely provenance of the offered materials - and that they comprised a third portion of an earlier complete body of records of which Hagley held the remaining two-thirds. However, Hagley staff determined that they did

\footnotetext{
${ }^{326}$ Gibb "Aims of the Specialist in Industrial Collections" 1969, 1; Hugh Gibb to Richmond Williams, "Description of Duties," September 19, 1974, 1, Box 373, Folder “Annual Reports - Industrial Specialist," EMHFA/RG5; Gibb, “Job Description,” 1978; Gibb, “1969 Report,” 1.

327 Gilchrist, "Report-1962," 4.
} 
not offer any new information about Shipley. "[We are told] of your confidence in being able to sell the letters elsewhere without difficulty," Williams wrote to the agent, "I wish you well in that venture."328

Lacking access to Hagley's internal acquisition case files, it is unclear what role purchase had in Hagley's acquisition program. Many of the business collections acquired by the SICs were outright gifts or placed on deposit by active companies. Of course, the du Pont family and DuPont Company records were supported by endowments at the Longwood and Eleutherian Mill-Hagley Foundations. While these provided generous funds for imprints, it is less clear what level of funding was available for purchasing manuscript material. In addition to the collections mentioned above, minutes from Hagley staff meetings include only occasional mentions of manuscript purchases, such as the business and personal papers of Thomas Masters, of the New York mercantile firm of Markoe \& Masters (5.5 linear feet, 1800-1855), the records of a carpet firm, the Oxford Manufacturing Company (0.5 linear feet, 1864-1894), records of Harrisburg's Fairview Iron Works with the firm Jared Pratt \& Son (1.2 linear feet, 1837-1858), and a letter of du Pont de Nemours written a few hours after the fall of the Bastille. ${ }^{329}$

Williams was willing to consider the purchase of a very large collection. "We should acquire one or two more collections of the size and quality of the DuPont Company records," he wrote, "even if we must go beyond our geographic area." Thus, staff made at least two assessments of the large "Warshaw Collection of Business Americana," a collection of manuscript and printed materials collected by a scrap paper dealer in New York City. But Williams ultimately declined purchase of the collection, claiming the extensive (and expensive) collection was outside the main thrust of the library's collecting efforts. Most importantly, the collection's strength appeared more in printed graphical material rather than the types of manuscript material Hagley sought.

\footnotetext{
${ }^{328}$ Quoted section to "reap a reward" is from Richmond Williams to Earl Moore, March 8, 1979. Quoted section about "confidence in being able to sell" is from Richmond Williams to Dale Fields, June 9, 1980; and John Riggs to Richmond Williams, "The Shipley Bringhurst Collection," June 9, 1980. See also John Riggs to Richmond Williams, "Collection of Riehle papers offered by Earl Moore," March 7, 1979. All of these sources are located in Box 363, Folder "Offers Declined, EMHFA/RG5.

${ }^{329}$ David, "Third Annual Report," 1958, 8; David, "Fifth Annual Report," 1960, 6; Williams, "Sixth Annual Report,” June 1961, 1, Box 169, Folder “Annual Reports-Library, 1960-1967,” EMHFA/RG5.
} 
The collection was later purchased by the Smithsonian Institution (and is described in a subsequent chapter of this dissertation). ${ }^{330}$

Williams and the staff continued to feel that "something dramatic and significant" was needed to make the Library more visible nationally. The thought was to attract one or more "nationally important collections," and Hugh Gibb's background in railroad history encouraged Hagley to consider a big acquisition there. These combined desires resulted in one of Hagley's largest and most important projects: the acquisition of records from the Reading Company (1,131 linear feet, 1795-1979). ${ }^{331}$

Reading had succeeded the Philadelphia and Reading Railroad, one of the first American rail lines. Founded in 1833, Reading had become the holding company for a system of railroads, canals, and coal mines. Hagley had received one block of Reading materials from the Pennsylvania Historical Society in 1964. By 1970, that block had received preliminary sorting, but was still not available to researchers. Williams and Gibb developed contacts with the firm - and had secured a general agreement for a records deposit - when the Reading Railroad filed for bankruptcy protection in 1971. 332

When bankruptcy proceedings concluded, new blocks of Reading records began to arrive in 1974. The sheer bulk of the new transfers and limited staffing required creative approaches. Materials were selected during seven different trips in August and September. Some materials were quickly inventoried and made available for research, including more than 500 account books and 621 letterpress books of outgoing correspondence. Loose incoming correspondence, the "most voluminous part of the collection," required more work. In addition to provenance, the project attempted to identify and re-establish original order. ${ }^{333}$

\footnotetext{
${ }^{330}$ Quoted section is from Williams, "Goals," 1966. See also Frank Battan, "New York Itinerary," July 2, 1959, Box 159, Folder "Miscellaneous Subjects," EMHFA/RG4; Williams, "1964 Report," 6; and Gilchrist "Report-1964," 3.

${ }^{331}$ Richmond Williams, "1966 Report," 8-9

${ }^{332}$ Gibb, "1971 Annual Report," 2. Gibb noted that the initial work by the Pennsylvania Historical Society had partially destroyed the collection's integrity, a factor which added to the cataloging challenge, Gibb, "1975 Annual Report," 1.

${ }^{333}$ Gibb, “1975 Annual Report,” 3.
} 
With the establishment of Conrail on April 1, 1976, Reading ceased to exist as an independent company. Hagley staff made five final trips to the Reading Terminal in Philadelphia, adding a considerable amount of material to the collection. Hugh Gibb noted: "We now have minute books plus more important legal documents of all of the Reading's absorbed subsidiaries.” By 1977, largely through the efforts of Hugh Gibb, Hagley had acquired more than 1,000 linear feet of records from the former Reading Railroad. The project marked an important milestone in Hagley's expansion beyond the du Pont family and the DuPont Company. "There are less than a dozen such railroad archives processed or in process for public use in these United States," reported Gibb. "The Reading, while small as railroads go, is important from the standpoint of innovation and it does represent the practice of the area in which EMHL is interested."334

The Specialists in Industrial Collections not only had a huge impact on acquisitions of industrial manuscripts, but also influenced changes in administrative structure and descriptive technique. With the Guide published and the primary work of organizing the du Pont family papers completed, Williams established a revised set of responsibilities for the Manuscripts unit, including documentation of the use of restricted collections, an in-house manuscripts exhibit program, a survey of repair and conservation needs, and work on a supplement to the Guide. In Williams' mind, however, the highest priority was processing the backlog of manuscripts and archival materials. John Riggs fussed that staffing was insufficient for this work and complained that the Specialist for Industrial Collection continued to exist administratively outside his unit. ${ }^{335}$

The influx of large amounts of non-DuPont business and industrial collections also encouraged a different approach to collection description, away from the item-level orientation Riggs had applied to the du Pont family papers and toward a modern archives approach beginning at the collection and series level. Richmond Williams was clearly

\footnotetext{
${ }^{334}$ Quoted section about "minute books" is from Gibb, "1976 Annual Report," 1; Quoted section about "less than a dozen" is from Gibb "1974 Annual Report." See also Williams, "1976 Annual Report." 4; Nash, "Business History at the Hagley Museum," 110; and Gibb, "1975 Annual Report," 1.

${ }^{335}$ Williams, "1969 Annual Report," 5, 12; Williams, "Implementation of Library Ten-Year Plan,” July 10 , 1969, Box 363, Folder “Operations of M\&A Department,” EMHFA/RG5; John Riggs to Richmond Williams, "Future Operations of the Manuscript Department," August 28, 1969, 1, Box 363, Folder “Operations of M\&A Department," EMHFA/RG5.
} 
aware of developing practice in this area through his participation in archival and manuscript professional organizations and his teaching at the University of Delaware. In addition to special techniques for business archives described by Arthur Cole and Robert Lovett, Williams was certainly familiar with the contemporary work of Theodore Schellenberg and Lester Capon describing the modern archives approach. ${ }^{336}$

The increasing appearance in internal documents of phrases and terminology such as provenance, original order, and "finding aid" reflected the change in ideology of most Hagley staff. John Riggs, however, continued to promote the centrality of the du Pont personal papers and a need for item-level description. "The fact that the du Pont family and business papers are the core of our manuscript holdings needs more emphasis," complained Riggs. Rather than acknowledging the value of the new accessions of industrial records, he only saw the "long hours of meticulous effort needed to provide intellectual access in these large modern collections." 337

We have been able to carry processing quite far in particular areas during the past, e.g., the Papers of Pierre S du Pont and the early groups of the Longwood and Winterthur Manuscripts. The numbering and carding of large masses of correspondence in the two latter collections has proved of immense service to the staff of the Foundation and to the scholarly public. $^{338}$

The SICs' work had identified very different techniques for processing and description, relying more on collection-level description and often working with the bound volumes of core business records. Hugh Gibb was even working with an archival student from the

\footnotetext{
${ }^{336}$ One example is a January 1969 student paper submitted by Linda Vollmar as part of a class Williams taught at the University of Delaware. The paper includes a concise overview of business history and existing archival practice in 1969, including references to archival principles of provenance and original order, as well as the more contemporary work of Theodore Schellenberg and Lester Capon. Reference is also made to the work of Arthur Cole and Robert Lovett with business archives at Baker Library at Harvard. It is likely that these texts were suggested by Williams. See Linda Vollmar, "Manuscripts Project Progress Report: The William Henry Collection," January 1969 (student paper submitted to Richmond Williams in connection with unnamed class H553, likely at the University of Delaware), 1, Box 373, Folder "Bibliography," EMHFA/RG5.

${ }^{337}$ Williams, "1976 Annual Report." 6.

${ }^{338}$ Riggs, "Operations in the Manuscripts \& Archives Department," 1977, 1-2.
} 
University of Delaware to do much of the organizing and description for new collections. ${ }^{339}$

Reductions in staffing occurred as endowment income dipped in the recession of the mid-1970s. The manuscripts unit lost a processing assistant who had worked with larger accessions, as well as a long-serving, part-time processing assistant who had started with French-language materials in the Longwood and Winterthur manuscripts. John Riggs responded with a curt, yet professional, memo on December 15, 1977, indicating that he and the remaining department staff would do their best to adhere to the prevailing standards. But necessary reductions in the level of descriptive detail in future inventories, he warned, would "place more effort on researchers to locate distinct elements within a large collection." The reductions would also limit staff support for detailed inquiries and photo orders, requiring patrons to provide precise citations for anything they required. Riggs was also quick to indicate how reduced staffing would slow work on the backlog of unprocessed new accessions. ${ }^{340}$

Richmond Williams turned outward to secure funding for several larger appraisal and processing projects. A grant from the National Endowment for the Humanities supported processing of the Pennsylvania Power and Light records deposited at Hagley in October 1976. A separate grant from the National Historical Records and Publications Commission (NHPRC) funded a project to appraise, select, and distribute pre-1968 records from more than 360,000 linear feet of records remaining in the possession of the Penn Central Corporation. Working with representatives from nine other repositories, appraisal and selection was finished in $1986 .{ }^{341}$

\footnotetext{
${ }^{339}$ Gibb, "1977 Annual Report," 1; and John Riggs, "Operations in the Manuscripts \& Archives Department," 1977, 6, Box 363, Folder "Operations of M\&A Department," EMHFA/RG5.

${ }^{340}$ Quoted section is from Riggs, "Operations in the Manuscripts \& Archives Department," 1977, 1-4. See also Riggs, "Operations in the Manuscripts \& Archives Department," 1976, 6.

${ }^{341}$ Initially, seven archival repositories participated: Hagley, the New York Public Library, the New Jersey State Archives, the Pennsylvania Historical and Museum Commission, Pennsylvania University, the Urban Archives at Temple University, and the Bentley Library of the University of Michigan. They were later joined by the Ohio Historical Society and Baker Library at Harvard University. Finding aid for the Penn Central Transportation Company Records, New York Public Library, http://archives.nypl.org/mss/2372, accessed March 27, 2017; See also Nash, Pennsylvania Power \& Light Company, xi; Christopher Baer, "Salvaging History," Railroad History, No. 192 (Spring/Summer 2005), 76-87; Nash, "1982 Annual Report," 1-3, 5; and Nash, "Business History at Hagley," 111.
} 
Riggs felt that Hagley should issue regular printed supplements to the Guide in addition to reporting new collections to the National Union Catalog of Manuscript Collections. But he wished to move the time-consuming work of copyediting, proofreading, and indexing of future Guide publications outside his department. The continuing independent role of the Specialist in Industrial Collections still piqued Riggs. "In future operations the services of Mr. Gibb should be more closely linked with our operations," he wrote, hoping for focused work with Rigg's assistant, Ruthanne Hindes. "The principle of keeping our operations closed up, tightly, within a single big collection at a time, needs careful consideration. He and Miss Hindes should form more of a team in the future." ${ }^{342}$

John Riggs' stature at Hagley clearly eroded during the 1970s. His primary work for nearly two decades had been processing the du Pont papers and the preparation of the Guide and a shorter supplement, which was published in 1978 and included descriptions of additional acquisitions made between 1966 and 1975. Meanwhile, starting in 1962, Richmond Williams and the SICs had transformed Hagley's collections and the staff's approach to descriptive cataloging. Ironically, Riggs ultimately acquiesced and jumped into the industrial records fray, albeit briefly. Taking a page from the SIC model, his thirty-page survey of "Sources for Public Utilities in the Middle Atlantic States" in April 1980 reviewed the electrical generating industry and contained a detailed listing of public utility companies in Hagley's geographic area of interest. Building upon the large accession of records Hagley had acquired from the Pennsylvania Power \& Light Company, Riggs suggested working with other public utilities to inventory and microfilm additional records. But this industrial work was clearly outside Riggs' core interests in the pre-twentieth century European roots of the du Pont family. Riggs retired from Hagley in 1982, after 25 years of employment. ${ }^{343}$

\footnotetext{
${ }^{342}$ Riggs, "Operations in the Manuscripts \& Archives Department," 1977, 4.

343 "We cannot house masses or original records, but we can accommodate a great deal of microfilm." Upon this recommendation, Hagley succeeded in microfilming 36 reels of records from the Philadelphia Electric Company and its dozens of subsidiaries. See John Riggs, "Sources for Public Utilities in the Middle Atlantic States," April 29, 1980, Box 364, Folder "Report - "Sources For Public Utilities in The Middle Atlantic States, 1980," EMHFA/RG5.
} 


\section{Maturity and Stabilization, 1982 to Present}

It is appropriate to close this study of the founding and early development of the manuscript collections at the Hagley in 1982. In that "year of transition," both John Riggs and Ruthann Hindes retired. Although Hugh Gibb continued in a part-time capacity processing projects, the position of Specialist of Industrial Collections formally ended following his retirement in 1979. During a "year of rapid personnel change," Michael Nash was hired as curator of the Manuscripts and Archives Department and began work on November 7, 1982. Chris Baer, who had started in a part-time role in the late 1970s, was elevated to the full-time position of Archival Specialist in January 1983, reflecting, perhaps, that as a recognized repository for industrial records it no longer needed to acknowledge the theme in a specific position title. ${ }^{344}$

Table 3.1 provides an overview of the growth of manuscript collections at Hagley. Gathering consistent numbers is challenging, particularly before the 1961 merger of Longwood and Hagley when staff had little control over the collections. Riggs' itemlevel orientation preferred reporting of gross numbers of individual manuscripts, rather than discrete numbers of collections or standard measurements of linear of cubic footage. In fewer than thirty years, from 1954 to 1986, the manuscript collections had grown from P.S. du Pont's original holdings at Longwood, to more than 20,000 linear feet of records, 350,000 photographs, and 165,000 imprints. ${ }^{345}$ Although Hagley continued (and continues) to acquire new manuscript collections, most of its core holdings had been acquired previous to 1982, particularly between 1962 and 1979 during the employment of David Gilchrist and Hugh Gibb as Specialist of Industrial Collections. Chris Baer noted that an "old boys network" used by David, Williams, and the SICs to collect surviving manuscripts in the Brandywine Valley died out in the 1970s. ${ }^{346}$

\footnotetext{
${ }^{344}$ Michael Nash compiled annual reports for the Manuscripts and Archives Department which are held in Box 365, Folder “Annual Reports, 1956-1986," EMHFA/RG5. Most information in this concluding section draws upon reports from the period 1982-1986 unless otherwise noted.

${ }^{345}$ Extent numbers from Nash, "Business History at Hagley," 104.

346 The NHPRC project resulted in Hagley's acquisition of the records of the Reading Railroad's primary competitor, the Pennsylvania Railroad (2,000 linear feet, 1813-1968). Other notable acquisitions after 1982 would include coal producers Penn Virginia Corporation (115 linear feet 1864-1981) and
} 
Table 3.1 - Growth of Collections, Hagley Library, 1955-2017 347

\begin{tabular}{|c|c|c|c|c|}
\hline Date & Source of Information & $\begin{array}{l}\text { Number of } \\
\text { Accessions }\end{array}$ & Cubic Ft. & $\begin{array}{c}\text { Number of } \\
\text { Manuscript Items }\end{array}$ \\
\hline Sep 1955 & David, 1955 Report & & & 200,000 \\
\hline Dec 1955 & David, "Longwood" & & & 200,000 \\
\hline Jan 1958 & David, "Notes for a talk" & & & 500,000 \\
\hline Oct 1961 & Dedication booklet & & & $1,000,000$ \\
\hline Dec 1961 & Williams 1966 report & 316 & & \\
\hline Spring 1962 & Williams Manuscripts & & & $1,000,000$ \\
\hline Dec 1965 & Guide & 845 & & $2,580,000$ \\
\hline End 1965 & "Consideration / space" & & 5,000 & \\
\hline Dec 1966 & Williams 1966 report & 926 & & \\
\hline 1970 & Guide & & & $3,500,000$ \\
\hline Nov 1971 & Riggs "Memorandum" & & & $3,880,000$ \\
\hline End 1971 & "Consideration / space" & & 7,300 & \\
\hline Jun 1973 & "Preliminary History" & & & $5,000,000$ \\
\hline 1978 & Supplement to Guide & 1,525 & & $6,000,000$ \\
\hline 1982 & Nash 1982-1986 reports & 1,803 & 15,200 & \\
\hline 1986 & Nash 1985 annual report & 1,900 & 20,000 & \\
\hline 2015 & Wikipedia & More than 2,500 & 37,000 & \\
\hline Jun 2017 & Baer & 2,711 & 40,270 & \\
\hline
\end{tabular}

Westmoreland Coal Company (347 linear feet, 1854-1982), the Radio Corporation of America (RCA) records (250 linear feet, 1887-1983), MCI Communications Company records (now including 726 linear feet, 1849-1999), the Seagram Company (multiple collections now covering more than 700 linear feet, 1879-1996), and Avon Products (212 linear feet, 1880-212). Additional deposits from Unisys included its Remington Rand predecessor (30 linear feet, 1830-1975), separate corporate records while operating under the Univac (now including 616 linear feet, 1935-1985), and Sperry-Univac names (now including 237 linear feet, 1874-1995), as well as records of the Sperry Gyroscope Company (76 linear feet, 19101970). See Asher "Researching;” Nash, "1982 Annual Report," 3-7; Nash, "1983 Annual Report, 1; and Christopher Baer, personal interview, March 7, 2014.

347 January 1955 figure is from David, 1955 Report, 2; "Notes for a talk to the Wilmington Garden Club," 5; December 1955 figure is from David, "Longwood Library Program as Presently Conceived," 1; October 1961 figure is from Eleutherian Mills Historical Library, Record of Its Dedication, 4; December 1961 figure is recalled in Williams, "1966 Report," 1; Spring 1962 figure is from Richmond Williams, "Eleutherian Mills Historical Library," Manuscripts, 14:2 (Spring 1962), 38; December 1965 figures are from Riggs, Guide, v-vii; "End 1965" figure is recalled in Williams, "Consideration on the subject of space," 1; December 1966 figure is from Williams, "1966 Report," 1; 1970 figure is calculated from information about additions made between December 1965 and 1970 as indicated in Riggs, Guide, v-vii; November 1971 figures are from John Riggs, "Memorandum," November 16, 1971, Box 362, Folder "Accessions," EMHFA/RG5; "End of 1971" figures are from June 1973 figures are from Riggs to Williams, "Consideration on the subject of space," 1; Williams, "Preliminary Draft," 6; 1978 figures are from Riggs, Guide: Supplement (1978), ix; 1982 figures are extrapolated from Nash's annual reports from 1982-1986; 1986 figures are estimated for the move to the Soda House and are from Nash, 1985 report, 9; and June 2017 figures are from Chris Baer, personal e-mail communication, July 25, 2017. 
Nash described the rapid growth period at Hagley as "passively accepting" most collections offered. He declared: "Repositories can no longer accept all of the records," particularly the huge collections created by $20^{\text {th }}$ century corporations. "[W]e have neither the facilities nor the staff to handle collections which require tens of thousands of linear feet of storage space and dozens of person-years to process." In the five years following Nash's arrival, 1982-1986, acquisitions became more targeted and included fewer (though sometimes larger) collections. These included 1,700 feet of records from the Penn railroad project and another 850 linear feet relating to the Sperry-Univac computing and defense companies, but the remaining new materials averaged 450 linear feet per year. Nash turned the staff's focus from acquisitions to processing the backlog and to a re-examination of the collections' thematic, temporal, and geographic boundaries. Manuscript processing made a "significant dent" in the backlog, with Nash's annual reports noting average completion of more than 1,700 linear feet annually between 1982 and 1986. Nash also embarked on a reappraisal project to re-evaluate some low use collections, looking in particular at routine transactional records for sampling and/or disposal. Nash's annual reports also recorded annual figures for deaccessioning, often comparing numbers for incoming and outgoing materials with an indication of net loss in the overall size of collections. Although Hagley continued to build its collection into new topical areas, after 1986 it sought stasis in acquisitions and disposals relative to its available space. An additional significant bookend to this transitional period was the retirement of Richmond Williams in $1987 .^{348}$

Nash worked with Williams to force Foundation trustees to address the increasingly severe space problem, understanding that the manuscript collection would continue to grow, particularly in thematic areas not represented in its existing collections, even if not at the previous rate. Key to this was a multi-year plan began in 1982 to move the manuscript unit and its collections to a wholly different location. A historic building on the DuPont powder works property, the Soda House, stood near the 1961 Library building and was carefully converted into collections storage, staff offices and work

\footnotetext{
${ }^{348}$ Quoted section is from Nash, "1983 Annual Report," 2-3.
} 
spaces, and a public reading room. The two projects - weeding and new space - helped to determine which collections would be moved, which sampled, and which deaccessioned. Dedication of the Soda House facility occurred on October 22, 1986. The facility continues to serve as Hagley's primary manuscript facility. ${ }^{349}$

These significant changes in personnel and physical space, along with changes in direction with as much or more emphasis placed on processing, reappraisal, and deaccessioning as on manuscript acquisitions, represented a clear shift in emphasis at Hagley. While the period following 1982 is worthy of further detailed study, it does mark a natural end point for this case study examining the establishment and early development of Hagley's manuscript collections.

One mark of the maturity of the Hagley program may be reflected in a May 1978 visit from staff of the library of the Henry Ford Museum and Greenfield Village. This enterprise, based in Dearborn, Michigan, developed with many similarities to Hagley, including connections to an active industrial corporation, support from the Company's namesake family, and relation to a Company-related museum function. At this particular juncture in the development of the Henry Ford museum's library, its staff turned to Hagley as a model. The visit by Joan Gartland to Wilmington included time with five different Hagley staff, who noted that Hagley was in the "enviable position of owning practically everything in their subject field." As a fledgling repository Hagley had turned to Baker Library for inspiration; by 1982 the Eleutherian Mills Hagley Library had become the inspiration for newer arrivals into the field of business and industrial manuscripts. ${ }^{350}$

\footnotetext{
${ }^{349}$ In the case of the records of the Atlas Chemical Company, for example, sampling of routine chemical assays, plant construction, and accident reports reduced the collection from 2,000 to 500 linear feet, Nash, "1984 Annual Report," 2-3; Nash, "1982 Annual Report," 3, 5.

350 Joan Gartland to Douglas Bakken, May 22, 1978, Accession 195, Box 5, Folder 12 "Library Annual Reports, 1978-1981,” Benson Ford Research Center, The Henry Ford.
} 


\section{Commentary and Conclusions}

The Hagley Library emerged when family papers initially gathered by P.S. du Pont for a private research library joined manuscripts gathered at the Hagley Museum, including records of the DuPont Company, during development of an indoor-outdoor museum at the site of the company's original mill property. The 1961 construction of a purpose-built library building created a fully-functioning research repository which allowed scholars easy access to both du Pont family and company records, as well as a significant early imprint collection. An aggressive and directed acquisitions program targeted non-DuPont business and industrial collections, with directors and field archivists proactively expanding the scope of its holdings. Proximity to the University of Delaware also supported a specialized graduate program in industrial history which made particular use of the broad collections.

The roots of the Hagley as a private research library (Longwood) and a corporate museum (Hagley Museum) differed from Baker Library's roots as an academic library. At Longwood, access to the manuscript collections was initially limited to external scholars and at the Hagley Museum's library to the museum curator-researchers. Baker was more open. Although the consolidated Library became increasingly intertwined with the Hagley Fellows program at the University of Delaware, the Hagley remained an independent research facility lacking either the advantages or pressures that Baker Library had as a unit in a specific school within Harvard University. Baker Library certainly served as a model for Hagley, both for how to build a research collection for the study of American business and industry, but also as a foil against which Hagley's collections might "provide a correction to the New England bias in the history of American industrialization." In the end, both Baker and Hagley benefitted from the research activities of associated graduate students and faculty members, both in promoting their manuscript collections through scholarly presentations and publications and in locating new manuscript materials while conducting research in the field. In the case of the independent research collection at Hagley, staff publications and other 
promotional tools became increasingly important in attracting researchers, new manuscript collections, and other types of monetary support. ${ }^{351}$

Staff at both Baker and Hagley were active professionally, and many became prolific authors in historical, library, archival, and records management journals. The two cases provide alternative approaches to starting a new manuscript collecting program. Baker Library believed, at least initially, that staff educated and experienced in the world of business would be better positioned to "know" and collect records from that sector. The early results, particularly during Charles Eaton's tenure, were inconsistent and often of poor quality. Hagley, perhaps with the advantage of studying the development at Harvard, committed to hiring directors with doctoral degrees in history and experience in the administration of library and heritage collections. This allowed the two Hagley startups to move more quickly toward deliberate and successful manuscript collecting. Both developed and collaborated with networks of businessmen and historians to assist in identifying and acquiring manuscript material.

Of course, each institution encountered internal staff tensions - between collectors and processors, about specific acquisitions, and concerning the optimal balance between collections processing, reference service, and public programming. Although these tensions are somewhat universal in the archival sector (historically and contemporarily), they impacted both institutions' collections. As staff developed understanding of the magnitude of the manuscript resources available nationally, each repository limited its scope of collections geographically. In addition, each recognized significant changes in the format and extent of business and industrial records had occurred in the twentieth century and either limited their collecting to pre-1890 materials or became much more cautious in acquiring twentieth century records. The challenges of processing and describing business and industrial collections tracked alongside theoretical discussions in the archival profession nationally and are reflected in Hagley's transition from item-level description of the historical manuscripts tradition, championed

${ }^{351}$ Quoted section about Hagley providing a "correction" to New England bias is from Christopher Baer, "Salvaging History," Railroad History, No. 192 (Spring/Summer 2005), 7. 
initially by John Riggs, to the collection- and series-oriented archives that became dominant across the profession by 1979 .

Unlike Baker Library, where individuals such as Charles Eaton and Arthur Cole exerted significant individual control over manuscript acquisitions and collecting policies, Hagley's professionally trained staff sought collaborative discussions about collecting activity, some collegial and others confrontational. In addition, the boards of their governing Foundations - and individual members of the du Pont family - had considerable influence over budget expenditures, extending their control to decisions about the scope of manuscript collecting. Directors David and Williams remained attentive to those holding the purse strings, while also building justifications for bending their geographic scope when a specific set of manuscripts warranted consideration.

By 1982, Hagley had established itself as a key archival repository for industrial and business records from the mid-Atlantic region and as one of the few repositories nationally with clearly defined interests in industrial enterprises. Hagley's focus represented a departure from the primary interest Baker Library had in business and economic records. Although Hagley collected financial account books, it was also interested, perhaps more interested, in technological history, industrial production processes, correspondence, measured drawings, and laboratory research materials. By the end of their respective establishment periods, both Baker and Hagley had amassed a representative sample of industries in their regions. Subsequent collecting more often filled gaps in their existing holdings, replaced existing collections with "better" materials for similar sectors, or expanded the collections to cover new fields such as computing, aerospace, and venture capital enterprises. 


\section{CHAPTER 4. FOUNDING AND EARLY DEVELOPMENT OF MANUSCRIPT COLLECTIONS AT THE NATIONAL MUSEUM OF HISTORY AND TECHNOLOGY, SMITHSONIAN INSTITUTION, WASHINGTON, D.C., 1954-1983}

\section{Introduction}

The Smithsonian Institution's National Museum of American History (NMAH), known internationally for its artifact collections and exhibits, also holds a significant collection of manuscript material in technological and industrial history which includes more than 1,200 discrete collections, comprising over 17,000 linear feet of records. Historians visit the "Archives Center" within NMAH to access collections such as the George H. Clark Radioana Collection (220 cubic feet, 1880-1950), the Pullman Palace Car Company Photographs (128.5 cubic feet, 1882-1955), and the Baldwin Locomotive Works-Southwark Foundry and Machine Company papers (342 cubic feet, 1868-1945). These collections are the offshoot of the Smithsonian's 1954 decision to create a separate, new technology-oriented Smithsonian museum to be called the National Museum of History and Technology (MHT). The technology-rich nature of the exhibits planned for the new entity, which opened in 1964, provided the impetus for its important early manuscript collecting activities, which centered on the history of science, technology, and industry. Unlike either Baker Library or Hagley (which also included a museum component), however, the manuscripts collected for MHT were not initially intended to be a publicly accessible archival collection. Rather, these collections were initially gathered to support the personal internal research, publication, and exhibition needs of a group of curator-historians. ${ }^{352}$

\footnotetext{
${ }^{352}$ As this case study examines the development of the Museum through the establishment of its formal "Archives Center" in 1983, reference will generally be to MHT or "the Museum." MHT was officially an administrative unit within the United States National Museum, but some records indicated it ceased to exist as an administrative entity in 1967. MHT became the National Museum of History and Technology in 1969, although MHT and NMHT were used interchangeably by many employees. The name was changed to its current title, the National Museum of American History, in 1981. See "Agency History, 1957-present," National Museum of American History, Smithsonian Institution Archives, https://siarchives.si.edu/collections/siris_arc_218078 accessed May 9, 2017.
} 
As with Baker and Hagley, the founding and early history of the manuscript collections at the Smithsonian Institution's National Museum of History and Technology can be divided into three major phases: origins, rapid expansion, and maturity. But unlike Baker and Hagley, it is necessary to add a fourth phase, a long period of indecision, between "rapid expansion" and "maturity." The "origins" period was marked by random, small, occasional manuscript acquisitions. This period runs from the 1846 establishment of the Smithsonian Institution through the authorization of MHT in 1954. A period of "rapid expansion" of manuscript acquisitions followed from 1954 to 1967. One curator described the first decade of that span, culminating in the opening of the Museum in January 1964, as the "golden era" of collecting. The end of this "rapid expansion" phase was marked by the acquisition of the gigantic Warshaw collection (1,000 cubic feet) in August 1967. After this, MHT entered a period of indecision, characterized by slow growth and uncertainty about acquisitions guidelines, public availability, and storage issues. The period of "maturity" began in 1983 with the hiring of MHT's first professional archivist and the creation of a permanent, publicly accessible archival unit within the renamed National Museum of American History. Available data indicates a decline in new archival acquisitions in the history of technology and industry in the 1980s, while the broadened mission of the renamed Museum caused rapid expansion of manuscript holdings in other areas of American history. ${ }^{353}$

This case study of MHT draws from multiple sources. Historians have reviewed the Smithsonian's early focus on industry and technology, though none has provided any detailed history of the Museum's archival holdings. Unlike Baker Library, a surprisingly large volume of administrative records survive and are publicly accessible, including administrative correspondence from many offices and divisions within MHT, policy and procedural documents, minutes of collections committees, and the personal papers of key curators who collected manuscripts in the history of science and technology. Several of these central participants have also described their activities in scholarly articles and

353 Quoted about a "golden era" is from "The Life and Times of Robert M. Vogel, Ret.," SIA Newsletter (Fall 1988), 5. See also "Mission \& History,” National Museum of American History, http://americanhistory.si.edu/museum/mission-history, accessed April 23, 2017. 
other publications. To supplement these sources, the author conducted oral interviews to fill gaps in the primary and secondary sources. Finally, a printed collection guide, published in 1978, as well as acquisition information recorded in specific collection finding aids, help to track the development and growth of the repository's holdings. ${ }^{354}$

This research reveals that archival collecting at MHT was carried out by a number of curators with little formal curatorial or archival training who acted independently and with no central direction. This was different from Baker and Hagley where single individuals carried out or closely directed collection activities. The manuscripts MHT curators gathered were acquired in a haphazard fashion with little deliberate planning similar to some periods at its peer institutions. The justification for manuscript acquisition at MHT, however, was different. Manuscripts collection was carried out, supposedly, to provide MHT curators with background material for museum exhibits. This was often true, but it was more often to support the research mission of the institution. Unlike at the Hagley, however, the archival collection at MHT was never able to substantially free itself from the museum with which it was affiliated, perhaps because its promoters did not attract outside funding or have an endowment like the Hagley did. At MHT, formal archival policy only developed late and reactively to internal limits of storage space, demands for intellectual control over collections, and increasing pressure by external researchers for information about and access to manuscript material.

\section{Creation of Manuscript Collections at the Smithsonian Institution, 1846-1954}

Science and technology had a central place in the evolution of national history museums in the United States. As early as the 1830s, members of the National Institute

\footnotetext{
${ }^{354}$ Arthur Molella, "The Museum That Might Have Been: The Smithsonian's National Museum of Engineering and Industry," Technology and Culture, 32:2 (April 1991), 237-263; Marilyn Sara Cohen, American Civilization in Three Dimensions: The Evolution of the Museum of History and Technology of the Smithsonian Institution (Ph. D. Dissertation, George Washington University, 1980); Pamela M. Henson, "'Objects of Curious Research:' The History of Science and Technology at the Smithsonian," Isis, 90 (1999), S249-S269; Robert Post, "A Very Special Relationship:" SHOT and the Smithsonian's Museum of History and Technology," Technology and Culture, 42:3 (July 2001), 401-435; and National Museum of History and Technology, Guide to Manuscript Collections in the National Museum of History and Technology, 1978 (Washington: Smithsonian Institution Press, 1978).
} 
for the Promotion of Science displayed American innovation through exhibits and displays, some of them in space secured in the U.S. Patent Office. Philadelphia's Franklin Institute, founded in 1824 as an industrial mechanics institute, coordinated international exhibitions of invention and technology and served as a testing and quasi-regulatory professional body. The spirit of these early ventures was incorporated into Congressional discussion about how best to use the bequest of English chemist and mineralogist James Smithson "to found in Washington, an establishment, under the name of the Smithsonian Institution, for the increase and diffusion of knowledge." The 1846 act creating the Smithsonian called for a collection of "all objects of art and foreign and curious research and all objects of natural history." The Smithsonian's first Secretary, Joseph Henry, debated the best ways to fulfill both Smithson's bequest and the Congressional mandate, initially steering the institution away from collecting and hoping to direct activity more toward international exchanges of scientific information, particularly in the natural sciences. ${ }^{355}$

The 1876 Centennial Exposition in Philadelphia proved a turning point for the Smithsonian's growing collections, particularly those in science and technology. As part of Congressional support of the international gathering, the Museum's staff accumulated objects and produced a series of "government exhibits." At the conclusion of the exposition, Smithsonian staff convinced many of the exhibitors to donate their exhibits to the Museum. Materials from 34 countries, filling dozens of boxcars, were then transported from Philadelphia to Washington, D.C. Surviving literature fails to indicate whether any manuscript items were included in the material transferred to Washington. Most of what the Smithsonian acquired were objects of natural history. Most industrial and mechanical items - such as steam engines, machines, and manufacturers' exhibit

\footnotetext{
${ }^{355}$ For background on the founding of the Smithsonian Institution, see Henson, "Objects of Curious Research," S249-251. For information on the Franklin Institute and its Committee on Science and the Arts, see Michal McMahon, Technology in Industrial America: The Committee on Science and the Arts of the Franklin Institute, 1824-1900 (Wilmington, Del: Scholarly Resources, 1977) and Stephanie Morris, The Franklin Institute and the Making of Industrial America: Guide to the Microfiche Collection (Bethesda, Md.: Academic Editions, 1987). Bruce Sinclair makes only passing mention of the Institute's library in his institutional history Philadelphia's Philosopher Mechanics; a History of the Franklin Institute, 1824-1865 (Baltimore, Johns Hopkins University Press, 1974).
} 
samples - were sold by exhibitors to actual customers as operating products. Excitement over the nation's showing at the exhibition, however, encouraged Congress to fund a companion building to the Smithsonian's original structure, known locally as "The Castle" for it iconic architecture. The new National Museum of the Smithsonian Institution (later known as the Arts and Industries building) opened in 1881, filled with exhibits drawn from the exposition donations. ${ }^{356}$

Smithsonian curator George Brown Goode extended the chronological limits of the Museum's anthropology collections to include the modern age and, as a result, the new building soon exhibited materials relating to contemporary technology and industry. Curators for the modern age exhibits were often drawn from industry. They included John Elfreth Watkins, who was appointed as curator of transportation in 1885, the first curator in any discipline related to technology or industry. Entering the Museum via a successful railroad career, Watkins helped to secure and preserve artifacts such as the early steam locomotives John Bull and Stourbridge Lion. George C. Maynard had managed the District of Columbia telephone system and joined the Museum as curator of the "section of electricity" in 1898. His association with Alexander Graham Bell and Gardner Greene Hubbard led to acquisition of artifacts and some manuscripts in telegraphy, telephony, and aviation. ${ }^{357}$

The Museum's object collection grew dramatically in the early twentieth century, including a large transfer of original patent models in 1908. The few published notes about collecting during this period occasionally reference some archival manuscripts,

\footnotetext{
${ }^{356}$ Molella, "The Museum That Might Have Been," 239-241; Henson, "Objects of Curious Research," S253; Post, "A Very Special Relationship," 417; and Robert P. Multhauf, "A Museum Case History: The Department of Science and Technology of the United States Museum of History and Technology," Technology and Culture, 6:1 (Winter 1965), 48.

${ }^{357}$ Watkins left the Museum for a period in the 1890s, first to develop the exhibit of the Pennsylvania Railroad at the 1893 World's Columbian Exposition and then to head the department of Industrial Arts at Chicago's Field Museum. See Frank Taylor, "The Background of the Smithsonian's Museum of Engineering and Industries," Science, 104:2693 (August 9, 1946), 130-132; Richard Loomis, "The Telephone Comes to Washington: George C. Maynard, 1839-1919,” Washington History, 12:2 (Fall/Winter 2000/2001), 22-40; Molella, "The Museum That Might Have Been," 240-41; and Robert Vogel, "Assembling a New Hall of Civil Engineering," Technology and Culture, 6:1 (Winter 1965), 59.
} 
including single blueprints and small sets of engineering drawings of early steam engines. There is, however, no clear indication of a purposeful manuscript collecting activity. ${ }^{358}$

The initiative to develop a separate museum specifically for engineering and industrial history began under the leadership of Carl W. Mitman. A former mining engineer, Mitman had toured the major European museums of science and industry while planning the Museum of Peaceful Arts in New York. He arrived at the Smithsonian initially in 1911, but took up a permanent position in 1918 as chief curator of technological collections and consolidated the Museum's holdings in civil and mechanical engineering. He believed the United States needed a strong national industrial museum, similar to Germany's Deutsches Museum, Britain's South Kensington Museum, and France's Conservatoire des Arts et Metiers. In 1920, Mitman approached the Smithsonian Board of Regents about establishing a separate "National Museum of Engineering and Industry." The proposal attracted some support from external donors to the point that initial architectural renderings were commissioned - and Mitman created a logo insignia for a "committee of one hundred" in support of the building project. But Mitman was unable to attract funding from either the Smithsonian's upper administration or the U.S. Congress, and the initiative died in 1927. ${ }^{359}$

Frank Taylor, Mitman's protégé and successor, took up the gauntlet for a museum of engineering and industry within the Smithsonian system. As a young man growing up on Capitol Hill in Washington, D.C., Taylor worked as a laboratory apprentice in the Museum's division of mechanical technology. His college career included an engineering degree from Massachusetts Institute of Technology and a law degree from Georgetown University. He returned to employment with the Smithsonian in 1933, working initially under Mitman to modernize the Museum's exhibits to make them similar to those Mitman had seen at larger European museums of science and technology. By the 1950s, the two had succeeded in attracting Congressional support for what would become MHT,

\footnotetext{
${ }^{358}$ Multhauf, "A Museum Case History," 48; Frank Taylor, Catalog of the Mechanical Collections of the Division of Engineering, United States National Museum (Washington, U.S. Govt. Print. Off., 1939), 15, 18.

${ }^{359}$ Taylor, "Background of the Smithsonian's Museum of Engineering and Industries," 131; and Molella, "The Museum That Might Have Been," 260.
} 
and the industrial holdings of Smithsonian had become "in effect, the national museum of engineering and industry in the United States" and had come to compare favorably with national museums of science and industry abroad. ${ }^{360}$

Although the Museum hadn’t amassed a significant amount of manuscript material prior to 1955, evidence points to some specific acquisitions. An early catalog of the mechanical collections of the United States National Museum's division of engineering references sketches of a 1776 Watt pumping engine, drawings of Robert Fulton's early steamboats Clermont and Chancellor Livingston, and a series of blueprints of George Corliss steam engines, including his 1876 Centennial engine which powered portions of the Philadelphia exhibition. J. Elfreth Watkins also acquired manuscript items during his tenure as curator in the late nineteenth century. Although best known for his acquisition of the locomotive John Bull, Watkins spoke widely to professional groups and conventions seeking historical materials and impressed on his former engineering colleagues "the importance of preserving the artifacts of railway's youth." One of Watkins' finest acquisitions was the records of the Baltimore and Ohio Railroad, which included drawings and lithographs, as well as 1,500 photographs documenting bridge construction, stations, and roadbeds. Watkins' acquisitions in rail history were the exceptions rather than the rule, however, and other industries and technologies appear to have been poorly represented by either object or archival material in the Museum's collections into the middle of the twentieth century. ${ }^{361}$

\footnotetext{
${ }^{360}$ Quoted section is from Carl Mitman's preface in Taylor, Catalog of the Mechanical Collections, 1. Biographical information about Taylor is from "Frank Taylor; Founding Director of American History Museum,” Washington Post, June 30, 2007, http:/www.washingtonpost.com/wp-dyn/content/article/ 2007/06/29/AR2007062902435.html, accessed April 23, 2017, and "Frank Taylor - Influential public servant and administrator who steered the postwar expansion and modernization of the Smithsonian," The Sunday Times (New York), July 30, 2007, http://www.timesonline.co.uk/tol/comment/obituaries/ article2163431.ece, accessed April 27, 2010 (copy in author's collection).

${ }^{361}$ Referenced collections are from Taylor, Catalog of the Mechanical Collections, 31, 39, 80-81. Quoted section is from Vogel, "Assembling a New Hall," 60. So few were the materials in civil engineering, Vogel was able to mention as a "notable exception" the 1942 acquisition of one line of trussing from America's first iron railroad bridge, see Vogel, "Assembling a New Hall," 60. Additional information from Robert Vogel, personal interview, May 30, 2009, and John White, personal interview, April 5, 2010.
} 


\section{Rapid Expansion of Manuscripts Collections, 1954-1983}

Congressional authorization for the Museum of History and Technology in 1954 was the result of decades of lobbying by dozens of curators, administrators, and supporters. Yet, there was little time for celebration - the new museum building required design, construction, new exhibits, and new collections. Taylor, Mitman's longtime colleague, was given the responsibility for planning the new museum and was formally appointed MHT Director in 1958. He would be succeeded in the director's role by John Ewers (1964-1965), Robert Multhauf (1966-1969), Daniel Boorstin (1969-1973), Brooke Hindle (1974-1978), Roger Kennedy (1979-1992), and others subsequent to this case study period, 1954-1983. ${ }^{362}$

Each director managed a small administrative workforce of assistant directors and clerical staff. The core work of the Museum, however, was carried out by curators with assignments in specific topical areas. Directors and curators constantly tinkered with the best way to organize staff, artifact collections, and conceptual themes in a logical structure. As a result, it is impossible to construct a coherent organizational chart for the period between 1954 and 1983. For example, the Museum's Division of Agriculture and Natural Resources, which dated to 1904, experienced significant name and reporting line changes during the period between 1957 and 1995.

In a 1957 reorganization, a new Department of Science and Technology inherited a Division of Agriculture and Wood Products from the old Division of Crafts and Industries. At the same time, a new Department of Arts and Manufactures housed a Division of Industrial Cooperation, which included the study of mining. In 1961 the Division of Industrial Cooperation was renamed the Division of Manufactures and Heavy Industries. A Department of Industries was created in 1969, along with the Division of Agriculture and Mining (formerly Agriculture and Forest Products). In 1976 Agriculture and Mining and the Division of Manufacturing merged to form a Division of Extractive Industries. In 1985 the Division of Extractive Industries became the Division of Agriculture and Natural Resources, and

362 “Agency History, 1957-present," National Museum of American History, Division of Agriculture and Natural Resources, https://siarchives.si.edu/collections/siris_arc_222941 accessed May 9, 2017. 
in 1995 Agriculture and Natural Resources was absorbed into a newly created Division of the History of Technology. ${ }^{363}$

While MHT's organization regularly shifted, there were some constants. The Office of the Director usually included at least one assistant director and other administrative staff. Interpretive and operation content was structured under three to five broad “departments," each containing two to six "divisions" overseen by a specific curator. Although there were many changes during the early development of the Museum of History and Technology, the technology departments usually included Science and Technology, Industries, and Applied Arts. The remaining history departments included National (or "Civil”) History, Military (or "Armed Forces") History, and Cultural History. ${ }^{364}$

The hiring of initial curatorial staff in key topical areas was a critical first step in transforming MHT from authorization to reality. Before ascending to MHT director, curator Robert P. Multhauf was a driving force in the new museum project. He joined the Smithsonian staff as associate curator of engineering in 1954, coincident to Frank Taylor's final legislative push for the stand-alone MHT. Multhauf was later promoted to oversee the department of science and technology and its numerous subunits, a venture which would be the primary focus of his work for more than thirty years. ${ }^{365}$

\footnotetext{
363 “Agency History, 1904-1995.”.

${ }^{364}$ Examples of departmental and divisional structures may be found in a manuscript report labeled "Sixth Floor - Archival" in Box 1, Folder 6, of the Archival Collections Administrative History Files, Archives Center, National Museum of American History; and Silvio Bedini to Messrs. Vogel, White, and Finn, "NMHT Archives," May 12, 1972, R.U. T90005, Box 1, Folder “Archives 1965-1972," Smithsonian Institution Archives.

${ }^{365}$ Born in South Dakota and raised in Iowa, Multhauf completed a B.S. degree in chemistry at Iowa State College in 1941. Following several years in the explosives and rubber industries, Multhauf joined the U.S. Navy and, following the end of World War II, stayed on in Japan to survey that country's scientific and industrial recovery. This work informed his master's degree in Far East Studies at Berkley in 1950, and his shift from industry to the history of science was confirmed with a PhD from U.C. San Francisco in 1953 with a dissertation examining the relationship between technology and natural philosophy in medieval Europe. Multhauf became director of the Museum in 1966 and four years later transitioned to the post of senior historian, the equivalent of emeriti status in academia. He retired from the Smithsonian in 1987. See Bernard Finn, "Robert P. Multhauf, 1919-2004," Technology and Culture, 46:1 (January 2005), 265-273; and Multhauf, "A Museum Case History," 51.
} 
Multhauf hired, in turn, curatorial staff with a mixture of academic, engineering, and industrial experience for his reporting units. One of those hires, Bernard Finn, recalled that "there were people like me who had a science or technical background and went back and took history courses." Pamela Henson, historian at the Smithsonian Institution Archives, claims that the change to "university-trained historians of science" occurred in the 1950s. Robert Post, a former Smithsonian curator and associate director, disagrees, saying that 'less than 20 percent' of the curators at the end of Multhauf's era were academically trained historians of science and that "many of the most productive [curators] had never been to graduate school." Regardless of educational background, few curators were hired from other museum organizations, and it is not clear if any arrived with any training in museum, archives, or library work. Both Multhauf and Frank Taylor believed the Museum needed to function beyond the simple collection-and-exhibit traditions of many institutions, and operate more like a university, with curators as serious researcher-scholars developing in-depth exhibits and publishing in scholarly journals. ${ }^{366}$

Where single individuals like Arthur Cole, Charles David, and Richmond Williams directed or closely controlled manuscript acquisitions at Baker Library and Hagley, manuscript acquisition at MHT was driven by multiple curators, each of whom had the autonomy of university faculty. Three of Multhauf's curatorial hires would play pivotal roles in the development of industrial manuscript holdings in the Museum: Robert Vogel, John White, and Bernard Finn. Between 1957 and 1983, these three curators gathered an enormous assemblage of artifacts in their areas of interest and designed the Museum's foundation exhibits as well as dozens of smaller or temporary installations. But they also amassed large amounts of unpublished manuscript material. By 1978, they managed close to two-thirds of the Museum's archival collections (see analysis later in this chapter).

\footnotetext{
${ }^{366}$ Quoted sections are from Bernard Finn, personal interview, March 1, 2010, Henson, "Objects of Curious Research," S264, and Post, "A Very Special Relationship," 410, note 26.
} 
Robert Vogel was the first to arrive, joining the Smithsonian staff in 1957. A collector who had developed an interest in history during his childhood in Philadelphia and Baltimore, Vogel had made regular visits to museums including the Smithsonian. He completed a bachelor's degree in architecture at the University of Michigan in 1954, but spent considerable time making trips to the Henry Ford Museum in Dearborn, writing term papers about steam engines, and working summer jobs at an isolated lumber camp in Idaho ("whole place run by steam; main saw driven by a large, elderly Corliss engine...Heavenly place; time warp.”). Following graduation, he worked as an architect for an East Coast contractor, but his thoughts turned more and more to museum work. The timing of his blind application letter to the Smithsonian "offering one with a solid appreciation of the technological past" couldn't have been better; Multhauf was looking for someone to help refurbish galleries for mechanical and civil engineering:

The only reason that they hired me, I'm quite certain, was that I had done as a term paper in my last year at the University of Michigan, a term paper titled "Factory Prime Movers of the Nineteenth Century." It was a paper that I had deeply enjoyed doing, heavily illustrated with Nineteenth Century woodcuts and engravings of steam engines, water turbines, motors and that sort of thing. And I brought that with me ... and I laid that on Multhauf's desk ... he kept it for a while, passed it around in the administration of the museum ... Had it not been for that term paper, I would not have been hired, I'm quite certain of that. ${ }^{367}$

Vogel was hired as a curator of heavy machinery and civil engineering in 1957 and remained in this general area of the Museum until his retirement in $1988 .{ }^{368}$

John "Jack" White arrived at Smithsonian initially as a summer intern in 1958. He had spent his youth riding streetcars, hanging around machine shops and engine rooms in Cincinnati, and building working models of various machines. His study for a bachelor's degree in history from Miami University in Ohio introduced him to some of the early literature on the history of transportation and technology. White also worked on an assembly line at a small manufacturing plant and held summer jobs creating scale

\footnotetext{
${ }^{367}$ Robert Vogel, personal interview, May 30, 2009.

${ }^{368}$ Quoted section is from "The Life and Times of Robert M. Vogel," 5.
} 
drawings in a drafting room, instilling a hands-on appreciation of technology.

Responding to an interviewer in 1990, White indicated that balance between practical knowledge and college training was important:

Certainly, an engineering background is going to impart insight that a straight historian probably won't have, but the crucial hands-on aspect may still be lacking. And engineers who haven't studied history are notoriously terrible historians. My argument is that practical experience and formal training are both essential to the making of a good technical historian. ${ }^{369}$

White interned under curator Howard Chapelle in the design of three new galleries for the fledgling Museum of History and Technology. Chapelle took responsibility for marine transportation, while White was tasked with producing exhibits on automotive and locomotive history. White ascended to Chapelle's position as curator of transportation in 1967 and transitioned to Senior Historian in 1986 before his full retirement from the Smithsonian in $1990 .^{370}$

Bernard "Barney" Finn was hired by Multhauf as curator of the Museum's electrical collections in August 1962. He completed a bachelor's degree in engineering physics from Cornell University in 1955 and worked initially as an experimental physicist in the nuclear power field. Pursuing an interest in the history of science, Finn returned to graduate school and worked under Irwin Hebert at the University of Wisconsin to complete a PhD in the history of science. At MHT, Finn remained responsible for electrical collections throughout his career, even while serving several periods as chair of multi-unit administrative departments within the institution. He retired in 2005 and transitioned to the position of curator emeritus. ${ }^{371}$

As these and other curators arrived at the Smithsonian, they faced very immediate demands to research, design, and test exhibits in their specific fields of concentration. MHT tried initial exhibit concepts in temporary installations in the Arts and Industries

\footnotetext{
${ }^{369}$ Robert Post, “A Life With Trains,” American Heritage Invention and Technology, 6:2 (Fall 1990$), 37$.

${ }^{370}$ Post, “A Life With Trains,” 35-40.

${ }^{371}$ Biographical information from "Powering A Generation: Finn Biography," http://americanhistory.si.edu/powering/bios/finn.htm, accessed April 23, 2017, and Bernard Finn, personal interview, March 1, 2010.
} 
building in the late 1950s, but most efforts focused on the new purpose-built facility to be opened in 1964. Developing exhibits for the new building included a push to locate and acquire new objects and support materials. As a result, during the period 1955-1964, the Smithsonian became a formidable collector. In addition to historical artifacts, Multhauf, Vogel, Finn, and White gathered large amounts of archival material. The late 1950s were particularly fruitful for those gathering collections for an emerging museum of industry and technology. World War II had heightened Americans' awareness of the importance of technology, and the return of a consumer-driven manufacturing boom had spurred new scientific discoveries and a range of machines and products of direct use to average citizens. The ascendency of radio, television, automobiles, and airplanes provided curators with challenges in how best to represent technical themes, how to interpret the operation and impact of historic machines and engines, and how to educate the Museum's visitors about innovations over time. Most importantly, a robust federal budget for travel, artifact and manuscript acquisition, and exhibit fabrication created a period which Vogel referred to as a time "of ferment, funding, new concepts, and hope - a golden era." 372

Curators interested in the history of pure science and technology, as well as manufacturing production and heavy industry, often sought donations from corporate enterprises engaged in these fields. In many cases, the "ask" was for three dimensional objects for study and exhibition, but the conversation often turned to product catalogs, operational manuals, photographs, and manuscript items. In contrast to Baker, MHT's curators' interests often focused less on the history of companies and more on the development of technologies and machinery. The Hagley was more likely to overlap with the Smithsonian's collection activities. John Hoffman, MHT curator for mining, for instance, found himself at odds with his counterparts at Hagley in 1967 concerning the records of the Lehigh Coal and Navigation Company (45 cubic feet, 1820-1965). Hagley's Director Richmond Williams wrote: "Our interests in this material are at opposite ends of the spectrum. You are interested in the engineering and technical materials - reports, blueprints, drawings, studies - relating to the technology of coal

372 “The Life and Times of Robert M. Vogel," 5.

Page 180 
mining in the anthracite region. We are interested in the economic and social consequences of the Old Lehigh Coal Company." Williams was being a bit disingenuous concerning Hagley's interests, particularly five years into their expansive collecting drive under David Gilchrist as their Specialist in Industrial Collections. Nonetheless his comments reflect the emerging reputation MHT was gaining for collecting specialized materials in engineering and technology. ${ }^{373}$

One important factor that drove MHT's collecting in certain areas was the problem of large technological objects. Certain technological fields - and their material culture - proved more difficult than others to collect and interpret. The representation of large objects from civil and mechanical engineering became a particular challenge. Vogel noted:

Despite its importance in man's adaptation to his surroundings, the field of civil engineering has, until the recent past, received hardly more than token treatment in technical museums anywhere. This deficiency is plainly a result of the size of the objects created by civil engineering. A bridge or dam does not respond to the format of a conventional museum exhibit with the same facility as a collection of rare coins, or an early surveying instrument, or even, for that matter, a locomotive. ${ }^{374}$

Historically, the Smithsonian fabricated scale models to interpret large objects. Frank Taylor's 1939 catalog of objects in the Museum's mechanical collection lists dozens of models - some constructed and submitted by companies in support of applications to the United States Patent Office (and later transferred to Smithsonian), others donated by companies directly to the Museum, and still others "made in museum" for use in earlier interpretive exhibits. ${ }^{375}$

Multhauf's initial hope of securing systematic collections of automobiles, planes, steam locomotives, and streetcars in the 1950s suggested obvious storage problems. As a

\footnotetext{
${ }^{373}$ Richmond Williams to John Hoffman, March 13, 1967, R.U. 276, Box 5, Folder 5, Smithsonian Institution Archives (the author is indebted to Dr. Eric Nystrom for sharing this source).

374 Vogel, “Assembling a New Hall," 59.

375 See, for instance, photographs of the models of the Conowingo hydroelectric generating station or the Corliss compound beam pumping engine in Taylor, Catalog of the Mechanical Collections, plate 9 and plate 18 .
} 
result, Vogel observed, "about the only point that was absolutely clear from the outset of planning" for the new museum "was that models would form the very foundation of the exhibits." In turn, the construction of accurate models was dependent upon reliable source material. "There was an enormous variation in the amount of data which could be located on the subject structures," noted Vogel in referring to the Museum's exhibit on bridge design, "ranging from the thinnest sort of fourth-hand account of a bridge's appearance, to full sets of original drawings."376

In cases where a model was either bulky or insufficiently detailed, curators turned to illustrations as a substitute, some from manuscript engineering drawings and others from earlier published accounts. And Museum administrators believed two dimensional materials would bear fewer costs than either models or full size artifacts. In one case, Frank Taylor denied a curator's request to acquire a historic Shay locomotive, claiming that although the engine itself would provide a "superior value" for study, the costs for handling and preserving would outweigh similar value from "a complete file of detailed drawings and photographs." For ease of access, these manuscript materials were assembled by curators in their offices in file cabinets, on available shelving, and in various flat file map cabinetry. Multhauf understood the importance of this background material to the success of a research-based museum institution:

The objective of our collection is the most accurate and complete record possible of the mechanical as well as the cultural history of transportation, which requires a degree of care in restoration and model construction not always apparent to the casual visitor. It requires as well a documentary collection of drawings, trade literature, and component parts, much of which remains largely in "reference collections," available to the public but used primarily in the production of exhibits rather than in the exhibits themselves. ${ }^{377}$

Although some of the manuscript items entering the Museum were employed to illustrate exhibits or to inform the creation of models, most of them were not formally accessioned

\footnotetext{
${ }^{376}$ Quoted sections are from Vogel, "Assembling a New Hall,” 66, 71. One senses that Multhauf felt strongly that the Museum should assemble a systematic collection of large objects and that models and other surrogates were only "expediencies of desperation." See Multhauf, "A Museum Case History," 52. ${ }^{377}$ Multhauf, "A Museum Case History," 53.
} 
into the Museum's holdings, and archival materials were rarely included as display objects in an exhibit. The vast majority of manuscript material was gathered for the sake of recording and documenting a given industry. "It was obvious that steam engines were becoming an obsolete form of machinery," recalled Vogel, "so when I went to Erie or to Milwaukee ... I was gathering stuff that I knew was going to record an eventually obsolete form of technology, the stationary steam engine." Similarly, Multhauf did not feel the Museum's new hall of electricity represented the "totality of our concern with electricity," referring readers to the Museum's reference collections "where the bulk of the collections in telegraphy, telephony, and radio are maintained." 378

It is important to understand the nature of these curator "reference collections," later described as "information files" in the 1978 printed collections guide. Different than discrete sets of personal papers and company records acquired and held as identified, separate, manuscript collections, the "reference collections" varied from division to division and from curator to curator. Some were simple internal reference or research files, similar to those amassed by a university professor or scholar during his/her professional career. Others were much more substantive, including trade literature, scholarly publications, clippings and pamphlets, copies of maps, floor plans, letters and diaries, and even some manuscript items. Most divisions had generalized collections in file cabinets within their office and work areas. They were held informally, with little standardized arrangement or description. Titles assigned to these curatorial collections in the 1978 guide included phrases such as "American Domestic Life Collections" (19 cubic feet), "Military History Information Files" (70 cubic feet), and "Textile History Collection" (3.5 cubic feet). Some divisions had specialized reference collections unique to their topical area: the Division of Naval History held a generalized collection of "Ship Drawings and Plans" (137.3 cubic feet); the Division of Mathematics had amassed a large

\footnotetext{
${ }^{378}$ Quoted section about the Shay locomotive is from Frank Taylor to P.W. Bishop, "Shay Locomotive," November 14, 1960, in R.U. 276, Box 20, Folder "Museum of History and Technology Archival Collections, 1966," Smithsonian Institution Archives (the author is indebted to Eric Nystrom for sharing this source). Quoted sections about steam engines are from Robert Vogel, personal interview, May 30, 2009, and Multhauf, "A Museum Case History," 56. Original manuscript drawings of the 1876 Kentucky River Bridge, Roebling's bridge at Niagara, and the St. Clair Tunnel are used as illustrations in Vogel, "Assembling a New Hall," 66 and figures 4, 5a, and 6.
} 
"Electronic Computers History Collection" (150 cubic feet); and numerous divisions held biography files or oral history files. Many MHT divisions also collected information about their own activities, including photographs of artifacts held within the divisions and documentary-style images of their exhibit installations. The Division of Musical Instruments maintained a "Sound Recordings Collection" (18 cubic feet) that contained tape recordings of musical performances given at MHT using restored instruments in its collections. ${ }^{379}$

Generous budgets for exhibits for the new 1964 Museum building made possible the curators' research, artifact purchase, and archival collecting. MHT's curators used a variety of techniques to locate and solicit manuscript collections: direct approach to firms that produced or used technology, requests to universities for outdated laboratory machinery and associated documentation, brochures to professional organizations, and, occasionally, purchase.

The direct approach to manufacturing firms probably yielded the largest volume. "The Smithsonian had a lot of prestige," recalled White. "Most people had at least heard of it [, and most] people had a pretty good opinion of it. So that did open a number of doors." Curators directly approached firms that had produced heavy machinery and engines about donating both artifacts and historical records. They also approached the municipal agencies that purchased and maintained engines for water and sewer systems. Although MHT had no formal policy concerning manuscripts, letters and circulars informed prospective donors that the "museum's archival function is a major aspect of our activities, assuring the collections under our care of proper indexing, preservation treatment, and permanent preservation in fire-proof, air conditioned surroundings." 380 In addition to approaching firms that manufactured and entities that used industrial machinery, curatorial staff also scoured older laboratories at universities and colleges for artifacts and documents. "You'd find the janitor or the head of the physics

\footnotetext{
${ }^{379}$ MHT, Guide to Manuscript Collections, various pages.

380 "An Archive for the History of Electrical Science and Technology," brochure, undated (likely 1972) Archival Collections Administrative History Files, Archives Center, National Museum of American History.
} 
department or whoever might be around and you say 'have you got any old stuff,", recalled Barney Finn. Many institutions with heat engine laboratories in mechanical engineering and structural laboratories in civil engineering were changing emphasis in the 1950s and 1960s and discarding obsolete machinery, Vogel recalled:

It was just sheer dumb luck that at that time this transition was occurring at institutions of higher learning. I can't think of the number of universities and colleges that I myself visited. Yale, Harvard, MIT, Lehigh, every major college and university, mostly in the eastern U.S., that had a heat engine lab, and we got engines and records ... Faculty in these areas were delighted to see these curators coming on to their campuses ... They hated the thought of disposing of this stuff. ${ }^{381}$

To supplement the material gathered from industrial firms and universities, curators also distributed special printed solicitations to members of the American Society of Civil Engineers (ASCE) and the Institute of Electrical and Electronics Engineers (IEEE) "as a means of extracting material of historical value" from their membership. The brochures were illustrated with manuscript items from the Museum's growing archival holdings, including Thomas Edison's early 1883 sketches of light bulbs, photographs of early Niagara power lines, reproductions of illustrations from trade literature and manufacturers' catalogs, and a set of 1873 drawings of an early pumping station on the Chesapeake and Ohio Canal. These brochures represented a direct call for donations:

An Archive for the History of Electrical Science and Technology

Raw material for the history of electrical science and technology is to be found scattered throughout notebooks, photographs, catalogs, patent records, motion picture films, audio tapes, and artifacts. But unless these resources are identified and gathered together in appropriate centralized locations they are virtually useless to historians, and the danger of their being destroyed is greatly increased... If you know of appropriate manuscripts, notebooks, catalogs, photographs, artifacts, please write to the Division of Electricity, National Museum of History and Technology. ${ }^{382}$

\footnotetext{
${ }^{381}$ Robert Vogel, personal interview, May 30, 2009.

382 "An Archive for the History of Electrical Science and Technology," brochure, undated (likely 1972).
} 


\section{Archival Collections in the History of Civil Engineering}

The U.S. National Museum invites submissions of records, plans, photographs, trade catalogs, journals and diaries, correspondence and personal papers as well as artifacts that are either relevant to the history of civil engineering or that are contemporary to earlier periods of history and relate to some phase of civil engineering. ${ }^{383}$

Vogel distributed more than 50,000 copies of the ASCE brochure with a reasonably good return on the cost of the mailing. "A lot of stuff came in" according to Vogel. "There was a little concern, I think, on the part of our museum's administration that we would be flooded with this stuff; we were not. It came in reasonable quantities and we were selective." 384

While not nearly as important as the direct approach to industrial firms in building up MHT's manuscript collections, the Museum occasionally purchased collections from private collectors and at public auctions. Of those acquired in this manner, by far the most significant was the Warshaw Collection of Business Americana (1,000 cubic feet, 1708-1977). The collection had been amassed by Isadore Warshaw, a New York amateur historian and scrap paper dealer, and included business ephemera such as advertising cards, posters, trade catalogs, and handbills. Hagley staff had examined it as early as 1959, but Richmond Williams ultimately declined purchase, claiming the collection's core content of printed graphical material was outside the manuscript focus Hagley sought. The material was brought to Jack White's attention in the early 1960s and elicited a very different response than that at Hagley:

\footnotetext{
383 "Archival Collections in the History of Civil Engineering," brochure, undated (likely 1966). Several drafts of the brochure, including a printer's proof, are located in R.U. 276, Box 20, Folder "Museum of History and Technology Archival Collections, 1966," Smithsonian Institution Archives.

${ }^{384}$ John White's Quoted section about "prestige" is from John White, personal interview, April 5, 2010. Quoted section about archives being a "major aspect" of the program is from Robert Vogel to R.D. Johnson, Deputy Commissioner for Water, City of Chicago, November 19, 1965, R.U. 397, Box 13, Folder "Steam Misc. 1973-1981," Smithsonian Institution Archives. Quoted section about stopping janitors is from Bernard Finn, personal interview, March 1, 2010. Quoted section about "reasonable quantities" is from Robert Vogel, personal interview, March 5, 2010. See also Robert Vogel to Frank Taylor, Draft of Announcement - American Society of Civil Engineers," August 4, 1965, R.U. 276, Box 20, Folder "Museum of History and Technology Archival Collections, 1966," Smithsonian Institution Archives.
} 
I was just overwhelmed by the material. [A] Lot of it was early Nineteenth Century or middle Nineteenth Century...he was a scrap paper dealer, that's how he started collecting. And he thought some of this material was so marvelous that it shouldn't be turned into paper pulp, it should be preserved ... I think it's magnificent. I mean, it's ephemera. There's not George Washington's letters or notebooks or that, but it was everyday life represented in just any category you can think of. ${ }^{385}$

White convinced Vogel to make a visit, and he was equally impressed with the collection, particularly the 35,000 trade catalogs. "The great bulk of the catalogs were prior to 1875 with a large body of them in the period 1850-1865," Vogel reported to Multhauf in a May 2, 1966, memo. "It is important to realize the uniqueness of this collection," he continued, "There is, quite simply, nothing like it, anywhere, and can never really be again." With his curator's assurance that this was a one-of-of a kind opportunity, Multhauf convinced Smithsonian Secretary S. Dillon Ripley to allow an unprecedented $\$ 100,000$ purchase of the collection in August 1967. ${ }^{386}$

Lacking any significant oversight, MHT's curators collected following their own interests. Vogel, for instance, collected heavily in the area of engine manufacture -clearly beyond the representative sample really necessary for MHT's exhibit and interpretive needs. In addition to the huge collection from Baldwin-Southwark, Vogel acquired the records of steam and diesel engine producer McIntosh, Seymour and Company (93.6

\footnotetext{
385 John White, personal interview, April 5, 2010.

${ }^{386}$ Quoted section about the "uniqueness" of the collection is in Robert Vogel to Robert Multhauf and Silvio Bedini, May 2, 1966, R.U. 276, Box 81, Folder 7, Smithsonian Institution Archives. Information about the collection is from "Warshaw Collection of Business Americana, 1708-1977," http://sova.si.edu/record/NMAH.AC.0060, accessed April 26, 2017, and "Warshaw Collection of Business Americana, 1724-1977," http://americanhistory.si.edu/archives/d7060a.htm, accessed April 17, 2010. The acquisition of the collection proved very complicated extending over many years. Staff of the Museum of History and Technology were unsuccessful in attempts to attract corporate gifts for a portion of the purchase price, and the Smithsonian encountered significant challenges in meeting their contractual payment terms with Mr. Warshaw and his widow. See R.U. 276, Box 81, Folders 7 and 8 , Smithsonian Institution Archives. Information about Hagley's examination of the collection is covered in a previous chapter and sources include Frank Battan, "New York Itinerary," July 2, 1959, Box 159, Folder "Miscellaneous Subjects," Record Group 4; Richmond Williams, "1964 Report," 6, Box 169, Folder "Annual Reports-Library, 1960-1967," Record Group 5; and David Gilchrist to Richmond Williams, "Report of the Activities of the Specialist for the year 1964," undated, 3, Box 169, Folder “Annual Reports-Library, 1960-1967," Record Group 5; Eleutherian Mills Hagley Foundation Archives, Hagley Library and Museum.
} 
cubic feet, 1886-1939) and marine steam engine manufacturer Sun Shipbuilding and Dry Dock Company (53 cubic feet, 1875-1930). He also secured the records of the Skinner Engine Company (29 cubic feet, 1880-1960) and the Worthington Corporation (14.5 cubic feet, 1868-1960), the papers of steam engine designer Erasmus Leavitt (20.4 cubic feet, 1871-1917), and records from Nagle Engine and Boiler Works (11.3 cubic feet, 1890-1939), Hewes-Phillips Ironworks (4 cubic feet, 1906-1919), Providence Engineering Works (2 cubic feet, 1881-1933), the Atlas Imperial Diesel Engine Company (1.1 cubic feet, 1925-1967), and the Superior Engine Division of the National Supply Company (1 cubic foot, 1924-1949).

Vogel was selective in the records he requested from a company donor. He was specifically interested in the engineering and production aspects of these firms. Thus, few of his acquisitions included administrative records, such as accounting and financial ledgers or correspondence. More often, Vogel selected measured drawings and sketches of engines and other products, order and delivery books, catalogs and instruction manuals, and other types of engineering and shop records. He even assembled an artificial collection of 2,000 photographic prints and glass negatives, gathered during his collecting trips through Ohio, of machine tools, presses, steam engines, and other machinery. He titled the assembly: "Ohio Machinery Manufacturers Photograph Collection" (24 cubic feet, 1910-1920).

MHT's curators were not always successful in their attempts to secure records. Many companies weren't willing to give up their collections. Vogel distributed printed cards to be inserted into selected files which read: "This collection has historical value; if it is of no longer of use to this firm, would you kindly notify the Smithsonian Institution." It was often a disheartening journey. Many firms that had once built engines and heavy equipment had destroyed their drawing files decades earlier as the repair parts business dwindled and space was needed for other purposes. In some cases, curators arrived only a few weeks too late:

One that comes immediately to mind was the collection of glass negatives from the Pelton Water Turbine Company in San Francisco...I was in this guy's office and I said I believe you have a large collection of photographs and glass negatives of your various water turbines. And he said 'Oh dear, 
you should have been here two weeks ago.' You know, the old story that the curator hates to hear: 'If you'd only been here last week when we sent ... something like three dump-trucks full of glass negatives to the dump. ${ }^{387}$

Yet many of the direct solicitations proved successful, like a collection of 500 drawings of Corliss engines acquired in 1965 from the Sun Shipbuilding and Dry Dock Company of Chester, Pennsylvania (80 cubic feet, 1875-1930). Representing much of the firm's work from 1872 to 1900, Vogel remarked that "collections of mechanical drawings from such an early period have rarely survived in so complete a form."388

Vogel, Finn, and White produced impressive results. A few acquisitions highlights would include: records of electrical engineer and television pioneer Allen Balcom DuMont (33 cubic feet, 1929-1965) and DuMont Laboratories, which produced cathode ray tubes and sold some of the first domestic television receivers; records of the Baltimore and Ohio Railroad (26.2 cubic feet, 1826-1951); personal papers of William Hutton (30 cubic feet, 1830-1965), a civil engineer involved with a variety of nineteenthcentury bridges, tunnels, and canals; more than 13,500 images from the Pullman Palace Car Company (128.5 cubic feet, 1882-1955); and an immense collection of measured drawings from the Baldwin-Southwark Company (342 cubic feet, 1868-1945).

These successes came largely without design or purpose. In separate interviews, Vogel, Finn, and White agreed there was very little coordination or deliberation in this work. "I think it's fair to say that our archival collecting efforts before 1980 were conducted largely without plan or with any good notion of what we were going to do with the material once we got it," reported Barney Finn. "Our experience with objects led us to believe a) that we had a well-founded sense of what was important, b) that if we didn't take it when we found it there might not be a second chance, and c) that space would be created in response to the collecting effort." 389

\footnotetext{
${ }^{387}$ Robert Vogel, personal interview, May 30, 2009.

388 Quoted section about "historical value" is from Robert Vogel, personal interview, March 5, 2010. See also Robert Vogel, "A Collection of Early Steam Engine Drawings," The Smithsonian Journal of History, 1:4 (Winter 1967), 75-76. The Sun Shipbuilding records are officially described under the parent "Robert Wetherill Company," http://sova.si.edu/record/NMAH.AC.0992 accessed April 26, 2017.

${ }^{389}$ Bernard Finn, February 15, 2010, email interview.
} 
By the time exhibits for the new building were completed in 1965, curators found themselves responsible for large amounts of archival material. Vogel's survey of the archival collections of the Division of Mechanical and Civil Engineering recorded only one filing cabinet of material collected prior to 1955; ten years later his division needed the equivalent of 12 filing cabinets and 25 map case drawers to hold its reference collections. White's survey of archival material in the land transportation division noted a similar increase: in seven years, his unit had added 30 file cabinet drawers, 25 drawers of oversize flat file material, and two specialty cabinets for very large drawings of ships and steam locomotives. In addition to the 3,325 cubic feet of material counted in 1965, curators in the Department of Science and Technology projected a 25-33\% growth rate over 5 years in their archival collections. ${ }^{390}$

Although the Museum had hired staff to assist in planning for the new building and to research, design, and prepare its exhibits, none were trained or assigned to managing archival collections. "The problem I ran into was after you got the material," White recalled, “there wasn't a great deal of support on taking care of it. I mean, basically you were told, well, you collected this stuff, now it's your job to service it. [We had incredible challenges] organizing them, cataloging them and ... getting them ready for use, which was very time-consuming." One of the first pieces of administrative correspondence specifically referring to archival collections is a 1965 memo discussing personnel requests for archival assistants to help with the work of organizing this material. ${ }^{391}$

The purchase of the Warshaw Collection in 1967 would make matters far worse. Finn called Warshaw a "seismic shift" in the Museum's archival collecting activity:

\footnotetext{
${ }^{390}$ Department inventories are in R.U. 276, Box 20, Folder "Museum of History and Technology Archival Collections, 1966," Smithsonian Institution Archives, and data from 1965 is included in "Sixth Floor Archival" in Box 1, Folder 6, of the Archival Collections Administrative History Files, Archives Center, National Museum of American History

${ }^{391}$ Quoted section is from John White, personal interview, April 4, 2010. Robert Multhauf to John Ewers, "Budget Estimates Fiscal 1967, Priority of Positions," June 17, 1965, R.U. 276, Box 20, Folder "Museum of History and Technology Archival Collections, 1965," Smithsonian Institution Archives. John C. Ewers joined the Smithsonian in the 1940s as associate curator of ethnology. He later became assistant director and then director of the Museum of History and Technology.
} 
Vogel, White, myself and few others ... were out there collecting this stuff that was inevitably going to have to put pressure on the institution to do something about them. The Warshaw Collection really did that. That was the elephant here ... you couldn't hide it in your office or anyplace else. It required something to be done. ${ }^{392}$

Vogel agreed that Warshaw was a major step in MHT's acquisition of archival material.

"We paid a hundred grand for it at that time, that was significant. The volume it occupied was significant. Its nature was certainly significant." The Warshaw contents also implied a significant investment in inventorying and cataloging - likely to the item level - so that specific materials could be located for use. The large purchase price had Smithsonian administrators pressing for exhibit and publication of portions of the collection almost immediately, yet curatorial ethics required that the material be properly accessioned and inventoried before items could be removed for use. ${ }^{393}$

Even before Warshaw, MHT's curators had begun to be concerned about the archival material they had been accumulating. On June 17, 1965, Robert Vogel sent a memo to Frank Taylor and Robert Multhauf about "The Archival Collections." The memo served as a pre-emptive strike to justify the historical significance of these collections to the Museum - and the need to invest in space and personnel to properly manage the activity. Vogel's thoughts were informed by a project he had completed with a summer intern, Harold Skramstad, to assess and organize archival materials in his Division of Mechanical and Civil Engineering. After summarizing his division's collections, emphasizing the difficulties associated with collecting large museum objects,

\footnotetext{
392 Bernard Finn, personal interview, March 1, 2010.

393 Quoted section is from Robert Vogel, personal interview, March 5, 2010. See also Silvio Bedini to Robert Multhauf, August 2, 1967, R.U. 276, Box 81, Folder 7, Smithsonian Institution Archives. An unsigned correspondent added a handwritten note to the latter memo: "Don't you have to document the collection before we plan any exhibits with it? Doesn't this take time?" Extensive files describing the initial discussions of how best to organize and allow access to Warshaw are located in R.U. 276, Box 81, Folders 7 and 8, Smithsonian Institution Archives. Although it is not clear why he was chosen, John Hoffman, curator of mining, was assigned the task of managing the Warshaw collection. Yet little was done to improve description or access to the material and the collection remained in boxes in the Museum's basement vault for many years, closed to public access. See R.U. 334, Box 50, Folder "Archives - Warshaw Collections," Smithsonian Institution Archives.
} 
and the necessity of collecting "archival" material, Vogel referenced the unique responsibility MHT had for this type of material:

These collections are quite specialized and generally lack the intrinsic historical value that would make them acceptable to a large, general repository such as the Library of Congress or the National Archives... However, the acquisition, arrangement, and maintenance of documentary materials at the Museum of History and Technology is now carried out in a fairly haphazard manner. There remains a need for exerting some sort of control over such materials ... This does not necessarily mean the Museum of History and Technology should establish a formal archive or manuscript collection that would administer all the collections but rather that there should be some standardized means by which documentary materials of each division could be made known and accessible. ${ }^{394}$

Rather than simply encouraging someone else to develop guidelines for archival collections, Vogel appended a four-page model "Outline for The Management of the Archival Collection of the Division of Mechanical and Civil Engineering." The document acknowledged the adoption of "essential principals of managing an archival collection" from Lucile Kane's Guide to the Care and Administration of Manuscripts published by the American Association for State and Local History, as well as the Rules for Descriptive Cataloging in the Library of Congress: Pictures, Designs and Other TwoDimensional Representations. None of the surviving records indicate that Vogel or other Smithsonian curators were aware of T.R. Schellenberg's groundbreaking 1956 work, The Appraisal of Modern Public Records, or his 1965 study The Management of Archives. ${ }^{395}$

${ }^{394}$ Robert Vogel to Frank Taylor, Robert Multhauf, and Silvio Bedini, “The Archival Collections,” June 17, 1965, Accession T90005, Box 1, Folder “Archives 1965-1972," Smithsonian Institution Archives.

${ }^{395}$ Vogel requested that Skramstad's work be continued in a memorandum, Robert Vogel to Robert Multhauf, "Consulting work this winter for Mr. Harold Skramstad, September 7, 1965, R.U. 276, Box 20, Folder "Museum of History and Technology Archival Collections, 1966," Smithsonian Institution Archives. Lucille Kane first published her work in chapter form as, "Manuscript Collecting," in In Support of Clio; Essays in Memory of Herbert A. Kellar (Madison: State Historical Society of Wisconsin, 1958). It was subsequently published as Lucille Kane, "A Guide to the Care and Administration of Manuscripts," Bulletin of the American Association for State and Local History 11:11 (September 1960), 327-88, and then reprinted as a separate booklet for wider distribution. See also Library of Congress and Descriptive Cataloging Division, Rules for Descriptive Cataloging in the Library of Congress: Pictures, Designs, and Other Two-Dimensional Representations (Washington, D.C.: Library of Congress, 1959); Theodore Schellenberg, Modern Archives; Principles and Techniques. (Chicago, University of Chicago Press, 1956); and The Management of Archives (New York, Columbia University Press, 1965). 
Multhauf was generally supportive of the archival activity, but worried about the rate at which some curators were making acquisitions. "While I accept Mr. Vogel's argument for collecting manuscripts," he wrote to Taylor in June 1965, "my recommendation is for archival collection at a rate that does not exceed the digestive powers of our present organization." Multhauf understood that archival materials were particularly critical to curators dealing with mechanical and civil engineering or transportation subjects, but was concerned that administration of manuscripts would likely impair the curators' core research and other scholarly pursuits. ${ }^{396}$ In the end, Multhauf's disinclination toward new staffing lines was enough for him to suggest that the Museum consider transferring materials to the Smithsonian Institution Archives, which between 1964 and 1967 evolved into a separate administrative unit of the Smithsonian Institution with its own line-item budget. ${ }^{397}$

As director of MHT, Frank Taylor found the Museum's collection of archival material "a commendable exercise." Although agreeing with Multhauf on the possible need to consolidate all archives at the institutional level, he also recognized the need to catalog MHT's existing collections - and possibly expand the archival efforts of the Museum. Vogel likely took Taylor's equivocal tone as encouraging; within four weeks he had drafted his solicitation to the ASCE membership and prepared the mailing. Multhauf remained cautious; his memo to Taylor on September 15, 1965, indicated a reluctance to

\footnotetext{
${ }^{396}$ Quoted section is from Robert Multhauf to Frank Taylor, "Archival Collections - Vogel Memo of June 17," June 24, 1965, Accession T90005, Box 1, Folder “Archives 1965-1972," Smithsonian Institution Archives; Multhauf to Ewers, "Budget Estimates Fiscal 1967, Priority of Positions,” June 17, 1965.

${ }^{397}$ Robert Multhauf to Frank Taylor, June 24, 1965, Accession T90005, Box 1, Folder "Archives 1965 1972," Smithsonian Institution Archives. See also Silvio Bedini to Frank Taylor and John Ewers, June 28, 1965, R.U. 276, Box 20, Folder "Museum of History and Technology, Archival Collections, 1966," Smithsonian Institution Archives. William Jones Rhees was given the title "Keeper of the Archives" in 1891, and some form of institutional record-keeping continued within the Office of the Secretary thereafter. "The mission of the Archives became more research-oriented in 1965, when Samuel T. Suratt was appointed Smithsonian Archivist. The Smithsonian Institution Archives moved into new quarters within the Smithsonian Castle during Suratt's tenure." Taken from "A Brief History of the Smithsonian Institution Archives," http://www.siarchives.si.edu/sia/main_about.html, accessed April 18, 2010 (print copy in the author's collection).
} 
make any specific recommendations "until I am better informed as to MHT policy towards archives."398

As a result of these discussions, Taylor asked assistant director Silvio Bedini to assemble data about MHT's archival collecting activities and formulate an initial policy for consideration by the Museum. The first step in this process was to solicit a report from each of the divisions calculating existing holdings, anticipated annual additions "under the present program," and the anticipated returns from the ASCE collaboration.

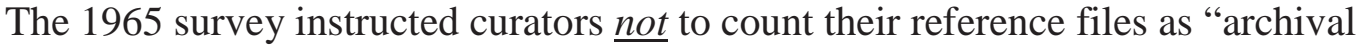
collections." Multhauf believed that much of the material curators had gathered was actually reference materials kept as an "independent resource" to identify and authenticate objects, to inform curators' scholarly research, or to answer public inquiries. Not surprisingly, curators protested at this separation. White's boss, Howard Chapelle, indicated that his transportation division did not maintain an "archival collection of independent resource." Vogel felt that "reference files cannot logically be separated from the distinct archival collections as the former contain much that is archival, and using the broadest definition, are entirely 'archival.,",399

The divisional reports, compiled in October and November 1965, provide a detailed snapshot of the Museum's archival holdings. Although the divisions of transportation and civil engineering held the largest amount of material, sizeable collections of manuscript items were also held by the medical and physical sciences

\footnotetext{
${ }^{398}$ Quoted section about "MHT policy" is from Robert Multhauf to Frank Taylor, September 15, 1965, R.U. 276, Box 20, Folder "Museum of History and Technology, Archival Collections, 1966," Smithsonian Institution Archives. See also Frank Taylor to Robert Multhauf, Silvio Bedini, and Robert Vogel, July 2, 1965; although an original of this memorandum was not located by the author, reference and excerpts from the document are included in several reviews of archival practice at MHT, including a summary of documentation entitled "Archives 1965-66" in the Archival Collections Administrative History Files, Archives Center, National Museum of American History, Smithsonian Institution. ${ }^{399}$ Quoted section is from Robert Vogel to Robert Multhauf, October 5, 1965, R.U. 276, Box 20, Folder "Museum of History and Technology, Archival Collection, 1966," Smithsonian Institution Archives. Bedini began his career at the Smithsonian Institution in 1961 as curator in the department of mechanical and civil engineering. By 1965, he had become assistant director of MHT, and in 1972 was appointed deputy director. He retired from the Smithsonian in 1987. See also Howard Chapelle to Robert Multhauf, September 30, 1965, Accession T90005, Box 1, Folder "Archives 1965-1972;" and Silvio Bedini to Robert Multhauf, September 28, 1965, and Robert Multhauf to Curators, "Survey of Archival Collections," September 29, 1965, Accession T90005, Box 1, Folder “Archives 1965-1972," Smithsonian Institution Archives.
} 
divisions. A summary of the collections across the combined departments indicated a total of 3,225 cubic feet of material - with growth predicted at 20-30\% in the next five years. ${ }^{400}$

This detailed survey revealed complete collections of primary source material acquired by curators from external sources - well beyond the normal types of research notes, copies, or single manuscript items curators were assembling in their "reference" or "information" files. The survey alerted Vogel to a collection of glass plate negatives and cyanotype prints documenting municipal pumping stations which became the Boston Water Works Collection (4 boxes, 1895-1919). The 1965 survey also reveals that Vogel had acquired the personal papers of Robert Cummings (20 cubic feet, 1884-1952), a civil engineer and early advocate of structural concrete. Vogel had also worked with Bedini to acquire the personal papers of architect Cass Gilbert (15 cubic feet, 1897-1963). The survey indicates that Finn worked with the International Business Machine Corporation (IBM) in 1962 to acquire the personal papers of William J. Hammer (36 cubic feet, 18741957), an electrical engineer who worked closely with Thomas Edison and who had collected materials about other scientists and inventors of his era. The survey of the Transportation Division described photographs of the railroad cars, streetcars, and shipyards of the American Car and Foundry Company and its predecessor, Jackson and Sharp (14.8 cubic feet, 1865-1927).

On October 18, 1965, in response to the large amount of manuscript material discovered during the survey, Bedini completed a "Policy on the Formation of MHT Archival Collections" for MHT Director Frank Taylor's review. The document indicated that all available space in MHT had "already been exhausted for offices, reference collections and areas required for activities supplementary to the operation of the museum." Any new space for archival collecting would need to be found elsewhere, and the space would need to be appropriate for these collections. In addition, the report

\footnotetext{
${ }^{400}$ Reports are held in R.U. 276, Box 20, Folder "Museum of History and Technology, 1966," Smithsonian Institution Archives. Summary data is from Department of Science and Technology, "Extent of Holdings at Present," November 1965, Box 3, Folder 1 of the Archival Collections Administrative History Files, Archives Center, National Museum of American History.
} 
acknowledged materials were difficult for either staff or visiting scholars to use, as there hadn't been time to properly screen, accession, and catalog materials. Not only did Bedini acknowledge that such work was unlikely in the near future, but he noted that additional acquisitions would only multiply the problem. Finally, Bedini said, there were "considerable costs involved with the acquisition of archival materials," including transportation, handling, and specialized storage cabinetry, which would have to be considered for any future acquisitions. ${ }^{401}$

Yet, despite these cautionary realities, Bedini was direct in his support for an archival program. "I feel strongly," he said, "that the acquisition of archival materials related to the collections of the museum is not only desirable but necessary." He referred to the possible creation of a "Smithsonian Historic Studies Center," which could absorb collections and manage them centrally for curators throughout the Museum. In the meantime, he maintained, "continued collection of archival materials should be accomplished under a clearly defined plan relating to all areas of the Museum, and such a plan should be affected as soon as possible."402

Taylor took comments on the draft from several curators and on May 2, 1966 issued a revised version in memo form ("Archival Collections in MHT") as a short-term policy statement. This second document included a direct statement from Taylor himself indicating that, for the short term at least, "each department or division will continue to exercise responsibility for its archival activities, including space and manpower needs within its own office or storage areas and with its own staff." In effect, Taylor opted to allow curators to continue collecting industrial records - asking them to "show judgment in their collecting and planning" - as long as they didn't ask for more space or personnel. Although he suggested a "Committee on Archival Collections" be established to study the problem further and make recommendations, there is no record of such a committee being seated in 1966. One may speculate that additional space and personnel for

\footnotetext{
401 Silvio Bedini to Frank Taylor, "Policy on the Formation of MHT Archival Collections," October 18, 1965, R.U. 276, Box 20, Folder "Museum of History and Technology, Archival Collections, 1966," Smithsonian Institution Archives.

${ }^{402}$ Bedini to Taylor, "Policy on the Formation of MHT Archival Collections," October 18, 1965.
} 
manuscripts were not likely following so closely on the Museum's 1964 opening. It is also likely that Taylor's interest in these day-to-day concerns declined as he neared the end of his active career at Smithsonian. He transitioned to the position of director-general of museums for the larger Smithsonian system in 1968 and retired completely in 1971. The question of manuscript collecting would remain low on the priority list of subsequent directors, and Taylor's 1966 "short-term policy statement” would actually serve MHT as its de facto manuscript policy for the next fifteen years. ${ }^{403}$

\section{Indecision, 1967-1983}

The continuing lack of substantive policy or oversight resulted in little control over new acquisitions, a shortcoming that was aggravated by the purchase of the very large Warshaw collection in August 1967. For more than fifteen years after the Warshaw purchase, MHT would struggle over development of collection policies, creation of adequate space for storage of their manuscript collections, systems to support public discovery and access, and staffing of these functions.

"Every curator was on his or her own as far as collecting was concerned," recalled Vogel. Additional studies of the archival holdings were completed in 1972, 1975, 1976, and 1978, drawing in several external consultants, including Richard "Dick" Lytle, archivist at the Smithsonian Institution Archives. This provided one of MHT's first formal interactions with the institutional records section of the larger Smithsonian system. Lytle, who had a personal and scholarly interest in the history of technology, was concerned about the materials that had been collected by MHT curators like Vogel, Finn, and White. In 1974, Lytle invited Maynard Brichford, archivist at the University of Illinois, to survey and make recommendations on the larger holdings in the Department of Science and Technology. Lytle's assistant, Richard Szary, returned to the Museum in 1976, developing a more detailed inventory of manuscript items held throughout the building in offices, in collection areas, in the storage areas, and sitting on shelves

\footnotetext{
403 “Frank Taylor: Influential public servant," The Sunday Times (New York), July 30, 2007; and Silvio Bedini to Frank Taylor, "Archival Collections in the MHT," May 2, 1966, R.U. 276, Box 20, Folder "Museum of History and Technology, Archival Collections, 1966," Smithsonian Institution Archives.
} 
alongside artifacts and reference material. "I was kind of surprised at how much there was," Szary recalled later, but approached his survey in a collaborative and friendly manner, realizing that the Smithsonian's centralized archival unit could accomplish more by working with curator-collectors at MHT. That same year, Robert Friedel, a doctoral student and MHT fellow, made a more qualitative study of archival collecting activities amongst the Museum's curators by interviewing each about their personal practice. ${ }^{404}$ MHT curators were willing to discuss selection and review processes, but they were reluctant to relinquish any significant amount of autonomy and authority in their specific acquisition activities. "Maybe it was Multhauf, or Taylor, I don't know who, no doubt one day said 'there's a problem here," Vogel continued, "we've got to have some way of filtering the collections as they're offered." In August 1972 - six years after Taylor initially recommended it - a collections committee was finally created, albeit with some initially informal operating rules:

As I recall the, our protocol was that if it was smaller than a breadbox, they didn't bother with it, the curator alone was able to judge whether that was something suitable or not. Bigger than a breadbox, it had to go through the committee. And that involved a memo from the curator describing the thing, saying what it was and why he or she thought we ought to have it in the collection, what its significance was historically ... everything went through the director, I believe, in both directions. ${ }^{405}$

Barney Finn felt the committee's work was valid. "It still leaves the curator with quite a bit of freedom," he claimed, "but then there are certain criteria which you had to have."

\footnotetext{
${ }^{404}$ Quoted section about each curator being “on his or her own" is from Robert Vogel, personal interview, March 5, 2010. The surveys may be found in the following locations: Maynard Brichford, "Report on Archival and Manuscript Collections in the Department of Science and Technology, National Museum of History and Technology," June 1974, R.U. 334, Box 58, Folder "SI Archives Move, Dick Lytle," Smithsonian Institution Archives, and Brooke Hindle to Curators, December 3, 1976, Accession T90006, Box 1, Folder "Archival Holdings Inventory Study," Smithsonian Institution Archives. Richard Szary's "Report on NMHT Manuscript Survey," July 28, 1977, and Robert Friedel's survey are attached to a memorandum from Richard Szary to Douglas Evelyn, March 31, 1980, in R.U. 334, Box 50, Folder "Archives MAH Centralized Records Facility," Smithsonian Institution Archives. See also Robert Vogel to Science and Technology Curators, March 4, 1974, R.U. 334, Box 47, Folder "Archival Committee," Smithsonian Institution Archives. Quoted section is from Richard Szary, personal interview, May 14, 2010.

${ }^{405}$ Robert Vogel, personal interview, March 5, 2010.
} 
Curators could argue that new material was part of their ongoing collecting, filled gaps in their existing collections, or might be a new collection that they were anxious to get. "But the important thing was you had to write a memo of justification," Finn recalled. "The committee was not shy about sending the thing back and saying, 'you have not justified this. We have no reason to think this isn't a wonderful thing to collect, but you gotta tell us why." ${ }^{406}$

Yet, the Archives Committee was slow to take root. Records indicate it was initially seated in May 1972 and held its first meeting the following August. The committee was reconstituted in May 1973, again in November 1973, and yet again in May 1974. The infrequency of its meetings and disinclination toward creation of policy likely reflected the lack of priority for the archives problem. Administrative officer and registrar Virginia Beets, appointed to the committee in 1975, was frustrated at its inability to take action. In 1976 she complained to the director of MHT that the committee had only met once in the year since her appointment, had recommended only one collection for acquisition, and had developed "nothing momentous or practical" as far as any policy. "Bulky collections can come in willy-nilly with no controls and no guidelines or accountability for good management because we lack an archival system." Her memo ended with a plaintive plea: "Will you please help us get this situation under control?" Review procedures were normalized in 1977, with printed forms and a decision flow chart for both accessions and deaccessions in place by June $1978 .{ }^{407}$

\footnotetext{
${ }^{406}$ Quoted sections are from Bernard Finn, personal interview, March 1, 2010.

${ }^{407}$ Quoted sections are from Virginia Beets to Brooke Hindle, "Need for Active Archival Committee," March 19, 1976, R.U. 334, Box 47, Folder "Archival Committee," Smithsonian Institution Archives. The first meeting held on August 8, 1972, is recorded in Archival Collections Administrative History Files, Box 1, Folder 2, Archives Center, National Museum of American History. Memos tracking the establishment and prodding of the committee include Silvio Bedini to Messrs. Vogel, White and Finn, "NMHT Archives," May 12, 1972; Silvio Bedini to Daniel Boorstin, "Archival Committee," May 2, 1973; Silvio Bedini to All NMHT Staff, "Archival Committee," November 2, 1973; Silvio Bedini to Brooke Hindle, “Archives Committee," May 20, 1974; and the Archival Committee's Memorandum "Toward an Archival Policy for the National Museum of History and Technology," June 27, 1974, all in R.U. 334, Box 47, Folder "Archival Committee," Smithsonian Institution Archives. Copies of the "Document Transaction" form (Form \#SI-182/6-5-78) and "NMHT Document Inventory Report" (Form \#SI-193/6-5-78) are in R.U. 397, Box 14, Folder "Archives Subcommittee," Smithsonian Institution Archives.
} 
Hagley Library director Richmond Williams was invited in 1977 to "look over documentary holdings and to informally discuss ... the problems and possible solutions to collecting, processing and storing of such materials." Williams spent two days at MHT, reviewed the reports of Brichford, Szary, and Friedel, and met with staff, including members of the "Documentary Collections Committee" (as it was called at that time). Williams' report, completed in February 1978, clarified the absence of a clear policy for the acquisition and administration of manuscripts.

In my view the present situation has been caused by benign neglect at the highest policy level which allocates resources of the museum. Being in the museum business - not the archives and manuscripts business - has prevented the expenditure of sufficient monies to do the job properly ... Adequate library and archival support has taken a back seat to more pressing "museum" problems. It boils down to management allocation of resources to provide intellectual and visual access to the remarkable group of collections that have accumulated over the last fifteen years. ${ }^{408}$

While acknowledging the tension created by curators' desire to keep materials close at hand for their own research, he argued for the creation of a central facility with appropriate staffing and professional finding aids. "There is no real national center for research in the history of technology," Williams noted, and MHT could assume national leadership in the field by developing a professionally run archives. ${ }^{409}$

Each successive survey and report confirmed what the curators already knew: they had rich collections, but no systematic archives program. Curators complained about the seemingly constant calls for assessments. "About once a year someone asks us to report on two things - number of visitors ... and archival inventory," noted Don Berkebile, a curator in the Division of Transportation. "Since we have a computer, one would think that some of this information might eventually get fed into it, so that the perpetual questions could be answered quickly whenever they drift into someone's

\footnotetext{
${ }^{408}$ Richmond Williams, "Report on the Care and Management of NMHT Documentary Collections and Research Center," February 15, 1978, 7, Archival Collections Administrative History Files, Box 1, Folder 5, Archives Center, National Museum of American History.

${ }^{409}$ Williams, "Report on the Care and Management of NMHT Documentary Collections and Research Center;" and Brooke Hindle to Staff, June 3, 1977, R.U. 334, Box 47, Folder "Archival Committee," Smithsonian Institution Archives.
} 
mind." But these surveys also reflected continued expansion of the collections, particularly in the divisions run by Vogel, Finn, and White. Richmond Williams-a known professional in "the archives and manuscripts business," who headed an established manuscript repository for business and industrial records - likely provided the final authoritative voice. His 1978 report encouraged adoption of a standardized collection policy, establishment of acquisition guidelines and collection handling procedures, assignment of adequate space and staffing to the activity, and publication of a guide to collections. ${ }^{410}$

An immediate priority became the publication of a guide to collections. Drawn from Richard Szary's 1976 inventory, MHT's Guide to Manuscript Collections in the National Museum of History and Technology was published in 1978. Known subsequently as "the green guide" due to the color of its soft-cover binding, the 143-page publication included a foreword by National Museum of History and Technology (MHT) director Brooke Hindle describing the Museum's growing archival holdings:

Some relate directly to and describe the artifact collections while others, in some measure, substitute for them. Even with the most selective discrimination, it has been impossible to collect the largest objects or to provide satisfactory representation of real objects in many of our divisions. Increasingly it will become necessary to rely more heavily upon documentary collecting to preserve here the elements of historical and technological evolution. ${ }^{411}$

The 1978 Guide provided comprehensive and comparable descriptions for each of the Museum's archival collections. It also provided separate listings for the "information files" maintained in each division and the "personal papers and other collections" being held as discrete manuscript collections.

A tabular analysis of information in the 1978 Guide (provided in Table 4.1) confirms the dominant role Vogel, Finn, and White had in MHT archival collecting.

\footnotetext{
${ }^{410}$ Quoted section is from Don Berkebile to Jack White, “Archival Inventory,” June 30, 1972, R.U. 334, Box 47, Folder “Archival Committee," Smithsonian Institution Archives.

${ }^{411}$ MHT, Guide to Manuscript Collections, iv.
} 
Table 4.1 - Tabulations of Collections Held in MHT Divisions and Departments, $1978{ }^{412}$

\begin{tabular}{|c|c|c|c|c|c|}
\hline & $\begin{array}{c}\text { Number of } \\
\text { Information } \\
\text { Files }\end{array}$ & $\begin{array}{l}\text { Cubic Feet of } \\
\text { Information } \\
\text { Files }\end{array}$ & $\begin{array}{c}\text { Number of } \\
\text { Other } \\
\text { Collections }\end{array}$ & $\begin{array}{l}\text { Cubic Feet of } \\
\text { Other } \\
\text { Collections }\end{array}$ & \\
\hline \multicolumn{6}{|l|}{ Dept. of Cultural History } \\
\hline Div. of Ceramics and Glass & 2 & 11.5 & 2 & 5.5 & \multirow{7}{*}{$\begin{array}{r}\text { Total c.f. } \\
492.0\end{array}$} \\
\hline Div. of Community Life & 3 & 75.0 & 1 & 10.0 & \\
\hline Div. of Costumes & 3 & 63.1 & 4 & 10.1 & \\
\hline Div. of Domestic Life & 6 & 68.0 & 10 & 116.8 & \\
\hline Div. of Graphic Arts & 3 & 51.5 & 1 & 2.0 & \\
\hline Div. of Musical Instruments & 5 & 78.5 & 0 & 0 & \\
\hline Totals for Department & 22 & 347.6 & 18 & 144.4 & \\
\hline \multicolumn{5}{|l|}{ Dept. of History of Science } & \multirow{7}{*}{$\begin{array}{r}\text { Total c.f } \\
865.6\end{array}$} \\
\hline Div. of Electricity and Modern Physics (Finn) & 3 & 24.2 & 23 & 424.2 & \\
\hline Div. of Mathematics & 7 & 208.0 & 1 & 8.0 & \\
\hline Div. of Mechanisms & 2 & 14.5 & 6 & 22.7 & \\
\hline Div. of Medical Sciences & 3 & 70.0 & 10 & 8.5 & \\
\hline Div. of Physical Sciences & 4 & 40.0 & 14 & 45.5 & \\
\hline Totals for Department & 19 & 356.7 & 54 & 508.9 & \\
\hline \multicolumn{5}{|l|}{ Dept. of the History of Technology } & \multirow{7}{*}{$\begin{array}{r}\text { Total c.f. } \\
2,458.8\end{array}$} \\
\hline Div. of Extractive Industries & 7 & 104.9 & 17 & 143.1 & \\
\hline Div. of Mech. and Civil Engineering (Vogel) & 9 & 302.2 & 115 & $1,194.9$ & \\
\hline Div. of Photography & 2 & 46.5 & 0 & 0 & \\
\hline Div. of Textiles & 3 & 50.3 & 0 & 0 & \\
\hline Div. of Transportation (White and Chapelle) & 7 & 326.5 & 14 & 290.4 & \\
\hline Totals for Department & 28 & 830.4 & 146 & $1,628.4$ & \\
\hline \multicolumn{5}{|l|}{ Dept. of National History } & \multirow{7}{*}{$\begin{array}{r}\text { Total c.f } \\
1,247.1\end{array}$} \\
\hline Div. of Military History & 7 & 223.4 & 1 & 0.6 & \\
\hline Div. of Naval History & 7 & 246.8 & 20 & 75.5 & \\
\hline Div. of Numismatics & 2 & 13.5 & 1 & 10.5 & \\
\hline Div. of Political History & 2 & 90.0 & 15 & 10.3 & \\
\hline Div. of Postal History & 3 & 98.5 & 5 & 478.0 & \\
\hline Totals for Department & 21 & 672.2 & 42 & 574.9 & \\
\hline \multicolumn{5}{|l|}{ Orphan Collections (not assigned) } & \multirow{3}{*}{$\begin{array}{r}\text { Total c.f } \\
1,200.0\end{array}$} \\
\hline Warshaw Collection & & & & $1,000.0$ & \\
\hline N.W. Ayers Collection & & & & 200.0 & \\
\hline TOTAL & 90 & $2,206.9$ & 260 & $4,056.6$ & $6,263.5$ \\
\hline
\end{tabular}

${ }^{412}$ All data is drawn from MHT, Guide to Manuscript Collections.

Page 202 
Some clarifications and caveats about the tabular analysis are required. Some collections described in the 1978 Guide are not part of the holdings at the Museum today. The section in the Guide for the Division of Postal History, for instance, described four large collections of official federal records from the United States Postal Service (120 cubic feet, 1894-1966), the Railway Mail Service (38 cubic feet, 1922-1966), the Internal Revenue Service (54 cubic feet, 1863-1925, relating to revenue stamps issued during the U.S. Civil War), and the final proof sheets from the Bureau of Engraving (210 cubic feet, 1894-1966). There is some question as to whether the latter two collections might be better described as artifact assemblages, and much of this material was later transferred to the National Postal Museum. The combined 422 cubic feet of material in these collections does, however, skew a numeric analysis of collections listed in the 1978 guide. Other collections were subsequently reduced in size - likely when more fully arranged and described - such as the Baldwin-Southwark Corporation records which were estimated at 400 cubic feet in the 1978 publication, but now measure 342 cubic feet. ${ }^{413}$

Two collections gathered by Division of Transportation curator Howard Chapelle are also of note. They are both titled the same, the first appearing as the Howard T. Chapelle Papers (98.7 cubic feet, ca. 1920s-1970s) as a "personal papers" collection under the Division of Transportation in the Department of Technology and described as containing drawings and tracings produced or collected by Chapelle in connection with his research and publications on the history marine transportation. The second, also called the Howard T. Chapelle Papers (38.3 cubic feet, ca. 1920s-1970s), is listed as a "personal papers" collection under the Division of Naval History in the Department of National History and described as including drawings he made for a specific book on sailing ships in the United States Navy. Although I was unable to access documentation about these materials, it would seem that either or both could be considered "information files,"

\footnotetext{
${ }^{413}$ In 1990, the National Philatelic Collection at NMAH was recast as a separate Smithsonian entity, the National Postal Museum and moved into the newly renovated Washington City Post Office in 1993. See “Agency History, 1957-present," National Museum of American History.
} 
perhaps best combined and included as information files in Chapelle's home in the Division of Transportation.

Additionally, it may seem surprising that MHT collected relatively few holdings relating to the mining industry. These numbers are even smaller when one realizes that the Division of Extractive Industries was also responsible for both agricultural and textile-related manuscript collections and these totaled more than 75 cubic feet. Of the 150 cubic feet recorded as relating to mining, the most significant documented three eastern anthracite coal mining companies: Coxe Brothers and Company (40 cubic feet, 1886-1935), Lehigh Coal and Navigation Company (45 cubic feet, 1820-1965), and the Philadelphia and Reading Coal Company (25 cubic feet, 1866-1920). Although these collections are important to MHT's manuscript holdings in science, technology, and industry, they are obviously minimal in comparison to the materials collected by Vogel, Finn, and White - and even in comparison to other manuscript-poor divisions in MHT's departments of Cultural History and National History. Sadly, none of the principal curators of the Division of Extractive Industries from this period survives to help assess and explain these unexpected shortcomings in the collections. ${ }^{414}$

Yet for all of these caveats, the Guide provides an important and detailed overview of archival holdings in 1978, near the end of the Museum's most active phase of collecting industrial manuscript material. The tabular data confirms that MHT curators outside of science and technology acquired manuscript materials, such as the Harry $\mathrm{T}$. Peters Collection (100 cubic feet), including more than 1,600 early American lithographic prints and acquired in 1960 by the Division of Domestic Life. In 1975, MHT acquired the records of the N.W. Ayer Advertising Agency (200 cubic feet, 1889-1960), which complemented the expansive Warshaw Collection of Business Americana $(1,020$ cubic feet, 1708-1977). Neither the Ayer nor the Warshaw collection had a specific divisional home at the time of the 1978 printing of the Guide, though White and Vogel

\footnotetext{
${ }^{414}$ All of the three anthracite collections changed in their final measurements after archival processing: Coxe increased from 40 to 100 cubic feet and Lehigh from 45 to 72 cubic feet; Philadelphia and Reading was reduced from 25 to 17 cubic feet. As the temporal date ranges for each collection remained the same from the 1978 Guide, one must assume that material was not added to the collections. Based upon review of finding aids held in the Smithsonian Online Virtual Archives http://sova.si.edu May 9, 2017.
} 
had been involved in acquisition of the Warshaw collection and John Hoffman, curator of mining, was given responsibility for both collections. ${ }^{415}$

This analysis proves that the greater bulk of archival materials were managed by Vogel, Finn, and White, with their divisions responsible for $40 \%$ of MHT's total archival holdings as reported in the 1978 Guide. Their three divisions held 152 of the 260 discrete external collections of personal papers and company records. And if one discounts the federal postal collections formally deposited at MHT - and credits the three curators with acquisition of Warshaw - they were involved with more than $60 \%$ of the core archival materials.

The lack of significant manuscript collecting by the other dozen curators at MHT likely reflects their different collections and professional attitudes. For most, archival materials simply weren't necessary for effective interpretation of their particular areas of responsibility. Divisions of ceramics or pre-industrial cultural history didn't have the "huge and transient subject matter" of the technological and industrial areas curated by Vogel, Finn, and White, which required technical documents to develop models and dioramas. Many accepted that curators would naturally collect reference files in the course of their work to seek, identify, and interpret objects in their divisions, and which could be passed along to a curator's successor. But most did not see their work - or the mission of the Museum - as including acquisition and management of "genuine archives" of personal papers or the complete records of companies or other organizations. ${ }^{416}$

Although the input of archival consultants was constructive, some external voices were less supportive. Not surprisingly, both the Smithsonian Institution Archives and the Smithsonian Institution Libraries felt it would be better to integrate MHT's archival

\footnotetext{
${ }^{415}$ Information about the Ayer collection, including indication of Hoffman's connection, is included in the finding aid at http://sova.si.edu/record/NMAH.AC.0059 accessed May 13, 2017.

${ }^{416}$ Quoted section concerning "huge and transient" is from Brooke Hindle to The Curatorial Staff, "Preservation and Management of Documents Collection," March 22, 1977, Archival Collections Administrative History Files, Box 1, Folder 8, Archives Center, National Museum of American History. See also Barbara Coffee to Roger Kennedy, "Document Collecting Policy," July 28, 1980, R.U. 334, Box 50, Folder "Archives General 1980," Smithsonian Institution Archives; Paul Forman to Roger Kennedy, "Documents Collecting Policy," July 1, 1980, and Roger Kennedy to Paul Forman and Barney Finn, July 23, 1980, (which used the phrase "genuine archives"), both in R.U. 334, Box 50, Folder "Archives Document Collecting Policy," Smithsonian Institution Archives.
} 
functions into their existing "mainstream information activities," claiming it would be "no difficulty to administer such an operation." The Library of Congress was also concerned about the Smithsonian's manuscript collecting activity, especially during the initial work on a separate building for the National Air and Space Museum (NASM) in the early 1970s. "We are particularly concerned that activities of the Museum staff may extend to personal papers that we feel belong more appropriately here," Librarian of Congress L. Quincy Mumford indicated to Smithsonian Secretary S. Dillon Ripley in April 1971. "For many years," he continued, "there has been an understanding of the general roles of these two organizations: the Smithsonian Institution would principally collect artifacts, the Library of Congress would principally collect published materials and manuscripts." Ripley's response recalled the earlier writings of Taylor and Multhauf:

With regard to the National Air and Space Museum, assembling reference documentation for aerospace artifacts is, of course, standard procedure. Such documentation often includes appropriate biographical material, but there should be no conflict of interest here and any such material can easily be shared. ... we look forward to continued cooperation and good will between our two organizations. ${ }^{417}$

Michael Collins, the new NASM director, acknowledged "considerable overlap between our operation and theirs," and expected that the Smithsonian would "periodically step on their toes with audible results." Not surprisingly, the Library of Congress balked again in 1972 when MHT distributed its printed solicitation to members of the Institute of Electrical and Electronics Engineers (IEEE) seeking archival material for the Museum's self-styled "archives of electricity." Ripley ultimately calmed Mumford at the Library of Congress with assurances that future collections of personal papers would be referred to his institution rather than MHT, and a policy statement (primarily targeted to NASM, but covering all Smithsonian units) limited museums to collecting exceptional items for exhibit and some materials which may be needed for reference or research. Barney Finn indicated to Brooke Hindle that the policy statement ultimately "shied away from the real

${ }^{417}$ S. Dillon Ripley to L. Quincy Mumford, April 22, 1971, R.U. 334, Box 47, Folder “Archival Committee," Smithsonian Institution Archives. 
issues," including curators' fear that the Library of Congress and National Archives would not see the value in the things the curators wanted to collect. One may speculate about their possibly selfish desire to keep their "reference collections" of manuscript material close at hand, but some curators remained convinced that MHT was a "home of last resort" preserving unique materials which would otherwise be lost. ${ }^{418}$

Space for archival collections became increasingly difficult to locate, particularly as other Smithsonian curators in addition to Vogel, Finn, and White continued to acquire archival collections outside of the disciplines of science and technology. Curators remained concerned about the inability of the institution to adequately manage these materials and, in a few cases, even turned collections over to other institutions. "We were generally quite willing to have the material go to other appropriate institutions," recalled Finn. "Our main concern was preservation and we knew there were limitations on what we could do." White, for example, acquired - and later gifted - manuscript material from the Reading Railroad and the Lima Locomotive Works. "I got their whole collection but I simply couldn't take care of it," he recalled. "I didn't really have a place to keep it, so after it had been on temporary storage for a while, I finally gave it or worked out a deal with the California State Railroad Museum to take it." ${ }^{419}$

Publication of the Guide in 1978, nonetheless, announced, very publicly, that the Museum was operating its own internal archival repository. Requests for access to these archival collections by outside researchers now became a growing problem. In addition to operational access issues, external researchers clamored for more descriptive information about the collections, including container inventories, indexes, and archival finding aids. Although the Guide helped to identify what collections existed within the Museum's holdings, it offered little in terms of detailed description of the contents of drawers or

\footnotetext{
${ }^{418}$ All sources for this issue are from R.U. 334, Box 47, Folder "Archival Committee," Smithsonian Institution Archives: Quoted section about "mainstream information activities" is from Robert Maloy to Roger Kennedy, December 3, 1980; Quoted section from Michael Collins about stepping on toes is from a memorandum dated May 18, 1971; Quincy Mumford to S. Dillon Ripley, April 5, 1971; Dillon Ripley to Quincy Mumford, April 22, 1971; Dillon Ripley to Quincy Mumford, "DE\&NE and IEEE Archival Project," September 13, 1972; J. Shroeder, "Background Discussion," August 13, 1980; and Barney Finn to Brooke Hindle, "Library of Congress and Air and Space Museum Conflict," May 8, 1974, R.U. 334, Box 47, Folder "Archival Committee," Smithsonian Institution Archives.

${ }^{419}$ Bernard Finn, February 15, 2010, email interview; and John White, personal interview, April 5, 2010.
} 
boxes. Cynthia Swank, archivist for the advertising firm of J. Walter Thompson, provided voice to many frustrated researchers in 1981, complaining about the lack of arrangement or description of the N.W. Ayer Collection.

[T] he collection is virtually inaccessible. N.W. Ayer itself evidently has tried to obtain photocopies without much success. In fact the only people who seem to use the collection are Smithsonian curators who wish an advertisement as background for an exhibit.

In the urge to collect, some institutions have neglected the other basic archival functions of preservation, arrangement, and description. If the materials collected cannot be used by the public, why bother having such repositories? ${ }^{420}$

Lacking a central reading room, curators made arrangements for visitors to examine materials in their own offices. "If I had a visitor come in," said White, "I had to go sit with the visitor as long as he was there handling things. Otherwise, stuff was disappearing." While he felt an "obligation" to provide access to this material, it was "enormously time consuming," and he would soon argue that management should either limit such access or provide more clerical staff. Distribution of the Guide increased demand for access, highlighting the need for detailed inventories and a programmatic approach to manuscripts within the Museum. ${ }^{421}$

MHT curators faced many other internal pressures and issues. Throughout the 1970s, the Museum's documents and archival committees returned time and again to debates about terminology and definition. For some, it was a theoretical consideration: were manuscript items museum objects? Assistant Director Silvio Bedini was sure that the term "archival" was part of the problem, as curators weren't sure if the term was limited to documents, or extended to include drawings and other graphical material. Curator Otto Mayr felt that archival policies must also extend to photographs, films, and sound recordings, as these were also important to the Museum's work, and that

\footnotetext{
${ }^{420}$ Cynthia Swank to Arthur Breton, July 2, 1981, R.U. 334, Box 58, Folder "Warshaw Collection," Smithsonian Institution Archives.

${ }^{421}$ John White, personal interview, April 5, 2010; and John White to Harold Skramstad, August 22, 1972, R.U. 334, Box 47, Folder “Archival Committee,” Smithsonian Institution Archives.
} 
"collection management methods appropriate to our conventional 'object' collections are inadequate for these materials." Questions also continued to surface about curators' "reference files" and whether they constituted "archives" in and of themselves. It proved to be a challenging topic with many Museum staff approaching the issue from a material culture perspective and trying to differentiate information content within a written document from its artifactual value as a material object. Vogel found such debates about "when-is-an-object-an-object-and-when-is-it-a-document" to defy logic, with curators arguing over "exceptions or violations of common sense." Committee members considered a variety of words and phrases to formally refer to the manuscript holdings: documentary materials, archives, non-accessioned material, reference files, documents, two-dimensional material evidence. One curator went so far as to draw an "Object Classification Diagram," placing manuscript items into a schema based upon their use as material evidence for research. ${ }^{422}$

In spite of challenges from other curators about manuscript acquisitions - and perhaps even masked by the lack of policy and lack of close oversight - Vogel, Finn, and White continued to collect archival material. In 1971, Finn negotiated the transfer of a collection of objects and archival materials from the Western Union Telegraph Company (25 cubic feet, ca. 1840-1961). The materials had been collected over sixty years by the Western Union Museum, which operated within the engineering division of the Company. The Smithsonian had had an ongoing relationship with Western Union since the 1930, when the Company had borrowed and replicated telegraph artifacts from the Smithsonian for inclusion in their exhibit at the Century of Progress World's Fair in Chicago. Following the Company's closure of its internal museum, MHT's Division of

${ }^{422}$ The "object classification diagram" is part of Barbara Coffee to Documents Committee, August 21, 1979, Archival Collections Administrative History Files, Box 1, Folder 8, Archives Center, National Museum of American History. See also Silvio Bedini to Brooke Hindle, "re: Archival Committee," August 3, 1976, R.U. 334, Box 47, Folder “Archives Committee," Smithsonian Institution Archives; Otto Mayr to Robert Vogel, "Role of the 'Documents' Committee," January 29, 1979, Archival Collections Administrative History Files, Box 1, Folder 7, Archives Center, National Museum of American History; Paul Forman to Roger Kennedy, "Documents Collecting Policy," July 1, 1980, R.U. 334, Box 50, Folder "Archives Documents Collecting Policy," Smithsonian Institution Archives; and Robert Vogel to Otto Mayr, January 22, 1979, Archival Collections Administrative History Files, Box 1, Folder 7, Archives Center, National Museum of American History.

Page 209 
Electricity acquired the collections. Subsequent transfers from the Company and additional gifts from former employees eventually increased the size of the collection to 452 cubic feet. ${ }^{423}$

Vogel continued to make collecting trips, though declining budgets restricted their frequency. He added both artifacts and archival records to the collection. His interest in steam engines continued with correspondents in Illinois, Alabama, Georgia, Texas, Ohio, and New Jersey. One trip took him to Milwaukee where he examined the records of the Nordberg Manufacturing Company. Once a producer of steam engines, compressors, and pumping engines for the mining, marine, and municipal power industries, Nordberg had successfully transitioned into the diesel market and expanded to acquire a second manufacturing facility in St. Louis. Vogel's visit encouraged the company's management to offer a variety of materials, including administrative correspondence, blueprints, and glass plate negatives of its products, facilities, and workforce. Yet, Vogel remained disinterested in administrative files:

Inasmuch as this material is primarily of a "business" nature, it is my belief that it ought more properly to be preserved at a major repository of such material. The preeminent of these is at the Baker Library at the Harvard School of Business. They should be interested, and you might wish to offer it to them. ${ }^{424}$

Vogel eventually acquired a subset of the Nordberg records (14.6 cubic feet, 1891-1947), including blueprint drawings of representative products, order books, time records, and a large series of photographs of the Company's operations. He also acquired several three dimensional artifacts which have been exhibited at the Museum. There is no record that the remaining "business" records are preserved at Baker Library or any other repository. ${ }^{425}$

${ }^{423}$ See "Guide to the Western Union Telegraph Company Records," http://sova.si.edu/record/NMAH.AC.0205 accessed May 13, 2017.

${ }^{424}$ Robert Vogel to Richard Bains, August 17, 1979, R.U. 397, Box 13, "Nordberg Collection," Smithsonian Institution Archives.

${ }^{425}$ See Vogel's correspondence in folders titled "Steam Engines,' "Steam Miscellaneous," and "Nash International, Inc.," in R.U. 397, Box 13, Smithsonian Institution Archives. A collection of records from 
Other curators also considered notable collections of material. In September 1980, Silvia Fine Kaye, widow of actor Danny Kaye, offered her collection of archival materials pertaining to musical comedy theater. Curators were unclear which division should be responsible for the collection. While the Division of Community Life held materials related to the history of American popular entertainment, its curator, Carl Scheele, complained they were "not equipped or set up for the storage and management of archival materials." The Museum ultimately declined the collection, and it eventually made its way to the Library of Congress in 1990. Meanwhile, Ray Kondratas, curator in the Division of Medical Sciences, acquired the Parke, Davis Research Laboratory Records (179 cubic feet, 1867-1971) in 1982 when the Warner-Lambert Company bought out the firm and closed its research facility in Detroit. The Wisconsin State Historical Society had turned down the collection as being too narrowly focused on pharmaceutical research, but Kondratas argued that the laboratory and research notes would directly support his division's research in the history of public health, biological research, vitamins, and pharmaceutical manufacturing. Barney Finn's cover note to MHT Deputy Director Douglas Evelyn provided his support for the acquisition - and bemoaned the absence of any useable review procedure from any active collections committee. ${ }^{426}$

\section{Maturity and Stabilization, 1983 to Present}

Frustrations with terminology, policy, space, staffing, and accessibility finally pushed the Museum's administration to action in the late 1970s. As neither offsite storage, nor an addition to the building, nor additional support staff seemed possible (or

Busch Sulzer, the company the Nordberg Manufacturing Company acquired in St. Louis, are preserved at the Wisconsin Historical Society. The finding aid for this collection indicates they were donated in 1970. See finding aid linked from https://search.library.wisc.edu/catalog/999464878202121 accessed May 13, 2017.

${ }^{426}$ Carl Scheele to Silvio Bedini, "The Silvia Fine Kaye collection of musical comedy archival material," September 30, 1980, R.U. 334, Box 50, Folder “Archives - Social and National History," Smithsonian Institution Archives; finding aid to the Danny Kaye and Sylvia Fine Collection, Library of Congress http://rs5.loc.gov/service/music/eadxmlmusic/eadpdfmusic/2012/mu012007.pdf accessed May 14, 2017; Ray Kondratas to Bernard Finn, "Parke-Davis archives," July 2, 1981, and cover transmittal note from Bernard Finn to Douglas Evelyn, July 2, 1981, both in R.U. 334, Box 58, "Doug Evelyn Archives," Smithsonian Institution Archives. 
prudent), MHT's administration decided to carve out space for a centralized internal archival program within MHT. Director Roger Kennedy and assistant director Douglas Evelyn identified a space on the Museum's third floor to serve as a starting point for the endeavor. Just as the building was transitioning to a new name and broader mission - it became the "National Museum of American History" (NMAH) in 1980 - minutes for a new "Working Group on NMAH Archival Collections" record the final effort to create the archives:

Over the past ten years a number of attempts have been made to deal in a coordinated manner with the documentary collections of the Museum, but there has been little real progress. Yet documents are as much a Museum responsibility as the artifact collections ... Rather than beginning yet another study and "reinventing the wheel," it is now time to act. ${ }^{427}$

Evelyn created four subcommittees with crossover membership to address specific needs: Collection Policy, Processing and Control, Access and Use, and Central Facility. He instructed the committees to have reports and recommendations completed in less than two months, so that budget actions could fit with the Museum's October fiscal cycle, and assigned one of his assistants to help with convening meetings, taking minutes, and developing policy documents to keep the effort moving forward. ${ }^{428}$

Of the many issues addressed by the staff during this initiative, the work of the "Collecting Policy Committee" was perhaps most the interesting. Chaired by Robert Vogel, the committee initially took up the debate about terminology and definitions. Realizing the "intractable nature of policy issues relating to archival collections," the committee quickly opted to "work out a simple and coherent policy statement rather than a complex one." Working from a very short, five-point guideline document drafted by Jack White in 1980, the committee spent a significant amount of time debating the proper

\footnotetext{
427 “Minutes, NMAH Working Group on Archival Collections, Meeting of 22 July, 1981,” R.U. 397, Box 14, Folder "Archives Subcommittee," Smithsonian Institution Archives.

${ }^{428}$ A variety of documents pertaining to the subcommittees can be found in R.U. 397, Box 14, Folder "Archives Subcommittee," Smithsonian Institution Archives. See also Hindle to Curatorial Staff, "Preservation and Management of Documents Collection," March 22, 1977, Box 1, Folder 10 of the Archival Collections Administrative History Files, Archives Center, National Museum of American History; and Henson, "Objects of Curious Research," S267
}

Page 212 
nomenclature for this material, ultimately agreeing to the phrase "archival collections." Warning Evelyn that he might be "surprised at its brevity," Vogel delivered the committee's final collecting policy statement on September 10, 1981. It filled less than a single page and suggested a broad collecting scope for manuscripts at the nation's premier history museum:

The Archival Collection of the National Museum of American History has been established for the purpose of preserving and making available for research certain historical documents and materials. The collection includes manuscript and printed; verbal and graphic; and audio-visual materials.

The collecting policy with respect to this collection will be guided by the general objectives and the mission of the Museum: to collect, preserve, interpret, and display the material evidence of American history.

Emphasis is placed on:

1) Documents directly related to specimens in the present collections, particularly those that interpret or authenticate these objects;

2) Documents associated with donors, makers, or persons in any field of American history represented in NMAH;

3) Documents associated with all other subject areas of cultural, scientific, and technological history - stressing American developments;

4) Documents having exhibit significance;

5) Documents able to serve as surrogates for artifacts that cannot readily be collected.

Collecting priority should be given to pertinent material not actively being collected by other repositories, either within or without the Smithsonian, and to important material that might otherwise be lost.

Collecting determinations will be made by the curatorial staff, as appropriate, in consultation with the museum's archivist, and subject to the standing policies of the Collections Committee.

As the overall aims of the Museum may change over time, these collecting guidelines should be considered subject to periodic review. ${ }^{429}$

\footnotetext{
${ }^{429}$ Quoted section from Robert Vogel is from August 19, 1981, minutes of the Collecting Policy Subcommittee. This document, the policy statement, and Robert Vogel to Douglas Evelyn, September 10, 1981, are filed in R.U. 397, Box 14, Folder “Archives Subcommittee," Smithsonian Institution Archives.
} 
This policy statement drew together many of the operating tenets evolved during the Museum's developmental period. Although the Museum's core functions were the collection, display, and interpretation of historical artifacts, some manuscript items accompanied donations of objects (\#2), others were necessary in understanding, describing, and interpreting museum objects (\#1), while some were themselves worthy of exhibit (\#4). The challenges Vogel, Finn, and White faced in collecting large industrial artifacts clearly informed the possibility for documents to serve as surrogates (\#5). Yet, it was the inclusion of the sweeping search for documents "associated with all other subject areas of cultural, scientific, and technological history" in the center of the document (as item \#3, perhaps in the hope that it wouldn't attract too much attention there?) which underlined the Museum's intention to continue to broadly collect manuscript materials. The new facility, to be called the "Archives Center of the National Museum of American History," would begin operation in 1982.

While finalizing policy, space, and furnishings for the centralized archival repository, discussions by the four subcommittees also considered the appropriate education, skills, and status of the individuals likely to be given responsibility for managing the manuscript collections. Many were nervous that a separate archive - and a separate archivist - would reduce curators' influence in future manuscript collecting. Some curators suggested that this individual be given the title "curator" and meet the same expectations for research and publication as other curators. Robert Vogel was adamantly opposed to this:

We are on the verge of taking the Museum on a giant, innovative, constructive and extremely worthwhile step forward, in establishing a formal archive. It is perhaps the most important thing we will have done around here from the museological standpoint since the construction of this building ... if we don't place the facility in the hands and charge of a person who is first, last, and (nearly) solely a professional archivist, it is my sincere belief that we never will achieve the potential inherent in it. ${ }^{430}$

\footnotetext{
${ }^{430}$ Robert Vogel to Roger Kennedy, March 25, 1982, R.U. 334, Box 67, Folder “Archivist Position,” Smithsonian Institution Archives.
} 
In the end, Director Roger Kennedy determined that the position would be filled by an experienced archivist. A national search was launched in April 1982, with an initial round of nine candidates interviewed in August. The Museum hired John Fleckner in December, and he began work early in 1983. Fleckner came to the Smithsonian following eleven years at the Wisconsin Historical Society where he had worked with manuscript collections and local government records. ${ }^{431}$

Through its interactions with Richard Lytle and Richard Szary, MHT had forged a positive working relationship with the Smithsonian Institution Archives. Richard Lytle pledged his support for the new operation and its new archivist. He realized the varied collections at MHT would require a full range of control that would only be possible for someone trained to work with archives. In particular, Lytle hoped that the new hire would reverse MHT curators' requirement for item-level cataloging, which he found "economically wasteful," and employ "collective archival techniques" to quickly open more material for public use. While continuing to harbor some "misgivings about how you are proceeding," he wrote to Roger Kennedy, "I'd like to help nevertheless. If NMAH does the job well, I'll be happy." 432

Contrary to Fleckner's expectations, archival material from the Museum's divisions did not immediately pour into the new Archives Center. Transfers began slowly and on a very limited basis. Barney Finn was an early adopter, transferring the Western Union and Clark Radioana collections. "[B]ut other curators held onto . . . collections," Fleckner recalled, "it was really only in later years as those curators retired and as their successors retired, that these collections have begun to flow into the Archives Center." Richard Szary, following Fleckner's work from his office across the Mall in the Smithsonian Institution Archives, didn't necessarily characterize it as curator resistance

\footnotetext{
431 John Fleckner, personal interview, March 1, 2010.

432 Richard Lytle to Roger Kennedy, "Manuscript/Documentary Collections in NMAH,” December 30, 1980, R.U. 334, Box 58, Folder “S.I. Archives Move - Dick Lytle," Smithsonian Institution Archives.
} 
as much as a combination of affection and convenient access to the treasured manuscripts they had protected for many years:

[I]t was, well, you know, we just kind of collect these things for our own background research and I'm not sure we want to give them up to a central repository where they're going to be managed and we don't have direct access to them. We're going to have to call for them, we're going to have to sign them out, all of these types of things. And right now, we can just go into our storage area and pull it out whenever we need it. So I think that, I would characterize it more as that, that a lot of people didn't want to give up that almost personal or departmental control over the collections. ${ }^{433}$

Fleckner never felt a sufficient sense of urgency to try to force the transfer of materials ("we had plenty to do with other collecting areas and with the stuff that we already acquired"). Finn noted that the curators appreciated the hands-off approach. "There was no pressure on them, on us, to contribute things," he said. "They had more than enough to do and were quite content that these things should come in slowly." "It was pretty much voluntary," Jack White recalled. "No one came in and held a gun to your head" and forcibly removed collections from curators' offices. Some collections took many additional decades to make the move - the records of the Sun Shipbuilding and Dry Dock Company, which Vogel acquired in 1965, for instance, didn't move to the Archives Center until 2007. ${ }^{434}$

While Fleckner's arrival at Archives Center early in 1983 did mark the "giant, innovative, constructive and extremely worthwhile step" forward which many sought, it also brought Vogel's "golden era" of collecting decisively to a close. Manuscript collecting had slowed following the opening of the Museum in 1964. "There has since been a leveling off," Vogel claimed in October 1965, "and it can be expected to be considerably lower from now on." Museum funding experienced flattening federal

\footnotetext{
433 Richard Szary, personal interview, May 14, 2010.

434 John Fleckner, personal interview, March 1, 2010; Bernard Finn, personal interview, March 1, 2010; and John White, personal interview, April 5, 2010. The 2007 transfer of the Sun Shipbuilding records is noted in the finding aid, "Robert Wetherill Company," http://sova.si.edu/record/NMAH.AC.0992, accessed April 26, 2017.
} 
budgets for cultural agencies. "I think what really put an end to the golden age of money was the war in Korea and then Vietnam," notes Vogel. Personnel and acquisitions budgets never recovered their pre-1965 levels. John Fleckner recognized the unique opportunity given to curators such as Vogel, White, and Finn: "It was an unusual moment in institutional history when BIG COLLECTING could happen." (emphasis Fleckner) ${ }^{435}$

Through their work at Smithsonian - and as a result of their research and publications from the object and manuscript collections they helped gather - MHT curators became significant figures in the field of industrial and technological history. Bob Multhauf remained closely tied to the academic world, serving terms as president of the Society for the History of Technology (1966-1970) and the History of Science Society (1979-1980), as well as fifteen years as editor of the latter's journal Isis (19641978). Robert Vogel participated in the series of industrial surveys conducted between 1965 and 1969 that helped to formalize a standard recording process for industrial sites akin to the Historic American Building Survey (HABS). These projects were critical to the establishment of the Historic American Engineering Record (HAER) in 1969, and Vogel served as team historian on the first official HAER survey, conducted in the Mohawk-Hudson Area. Vogel was also responsible for convening a 1971 meeting at the Smithsonian which led to the founding of the Society for Industrial Archeology. He helped to shepherd this organization through its initial growing pains and edited the Society’s newsletter for more than a decade. MHT curators participated in teaching activities at university programs in and around Washington, D.C., and all were active in exhibit design, research, and publication. White was the most prolific, authoring a dozen books and more than one hundred articles. As was the case at both Baker and Hagley, publications by MHT curators and other promotional tools attracted external researchers and new manuscript collections, while building on the Museum's existing cachet as a part of the Smithsonian Institution. ${ }^{436}$

\footnotetext{
435 Vogel to Multhauf, "Survey of Archival Collections," October 5, 1965; and John Fleckner, September 14, 2010, email interview.

${ }^{436}$ Finn, "Robert P. Multhauf," 268-269; Robert Vogel, "The Prehistory of HAER, 1965-1968," CRM, 23:4 (2000), 5-7; "The Life and Times of Robert M. Vogel," 5-8; and Post, “A Life With Trains," 35.
} 
MHT also became an important player in the emerging academic fields of history of science, history of technology, and industrial archaeology, taking a role in training scholars in these fields. Although MHT had no formal ties to an educational institution, such as the ties between Baker and Harvard or between Hagley and the University of Delaware, by the 1970s and 1980s MHT did have a well-funded fellowship and consultancy program that brought an active stream of doctoral students and post-doctoral appointments into the Museum. It became a common saying that anyone "who hasn't spent a year or half a year at the Smithsonian is no historian of technology." ${ }^{337}$

It is difficult to summarize numeric data on MHT's and NMAH's archival holdings. None of the surveys included all manuscript material; some surveys counted curator reference files as collections; the orphaned Warshaw material was not consistently reported; and some surveys recorded collections in terms of numbers of file cabinets and map drawers (with no conversion to cubic feet). Nonetheless, Table 4.2 charts the available data. Archival acquisitions clearly continued after 1983. In addition to new acquisitions, some of the reference files gathered by curators in previous decades were transferred, post 1983, normalized as described collections, and counted more consistently. Still others were dismantled, distributed to other institutions, or discarded altogether.

After 1983, acquisition activities with the new Archives Center shifted to filling gaps in existing holdings, expanding to cover new fields in the history of technology, and serving the broader mission of the rebranded National Museum of American History instead of actively seeking out any and all materials that seemed to have some remote relevance to curators' interests. Although curators continued to pursue individual collections of interest to their specific divisions, Fleckner developed acquisition activities in a more sustained fashion in three areas. Building upon the Warshaw and Ayer collections, Fleckner secured other materials on the history of advertising, including several oral history projects with leaders in the industry. In the late 1980s, Fleckner worked with curator John Hassey to add major collections in the history of music,

${ }^{437}$ Finn, "Robert P. Multhauf," 264. 
including the Duke Ellington papers (400 cubic feet, 1903-1989) and the Sam DeVincent Collection of Illustrated American Sheet Music (260 cubic feet, 1790-1990s). ${ }^{438}$

Table 4.2 - Growth of Collections, MHT, 1965-2011 439

\begin{tabular}{|c|c|c|c|c|c|}
\hline \multirow{2}{*}{ Date } & \multirow{2}{*}{ Source } & \multicolumn{2}{|l|}{ Science \& Technology Dept. } & \multicolumn{2}{l|}{ Total All MHT Depts. } \\
\cline { 3 - 6 } & & $\begin{array}{c}\text { Number of } \\
\text { Collections }\end{array}$ & Cu. Ft. & $\begin{array}{c}\text { Number of } \\
\text { Collections }\end{array}$ & Cu. Ft. \\
\hline 1965 & Survey of S\&T department & - & 3,325 & - & - \\
\hline 1966 & Survey of all departments & - & 3,325 & - & 7,875 \\
\hline 1975 & Space Survey (Finn/Harris) & - & - & - & $6,919^{*}$ \\
\hline $1976-77$ & [unknown] & - & 3,413 & - & 4,954 \\
\hline 1977 & Szary Survey & - & 2,273 & - & $5,141^{*}$ \\
\hline 1978 & Green Guide & 247 & 3,315 & 348 & $5,063^{*}$ \\
\hline 1986 & Fleckner/Crew & - & - & 242 & 4,500 \\
\hline 2011 & Archives Center survey & 460 & 5,842 & 1,237 & 17,281 \\
\hline
\end{tabular}

Note: totals marked with an asterisk (*) do not include the Warshaw Collection

While some areas Fleckner developed were outside the earlier focus on the history of technology, he also sought in a more nuanced manner to fill gaps in existing technology and industry collections and expand into new areas in the history of technology. For example, MHT's Archives Center partnered with the Smithsonian's Lemelson Center for the Study of Invention and Innovation to add archival collections in the broad areas of invention, business, marketing, and technology. A few highlights of

438 The three areas for expansion were described to the author by John Fleckner, personal interview, March 1, 2010. See also Fleckner and Crew, "Archival Sources for Business History," 485.

4391965 figure is from Department of Science and Technology, "Extent of Holdings at Present," November 1965, Box 3, Folder 1 of the Archival Collections Administrative History Files, Archives Center, National Museum of American History; 1966 figures are from an untitled survey in a folder labeled "Sixth Floor - Archival" in Box 1, Folder 6, of the Archival Collections Administrative History Files, Archives Center, National Museum of American History; 1975 figure is from Finn and Harris, "NMHT Space Survey;" in a folder labeled "Sixth Floor - Archival" in Box 1, Folder 6, of the Archival Collections Administrative History Files, Archives Center, National Museum of American History; 1976-1977 figures are from an untitled survey in a folder labeled "Sixth Floor - Archival" in Box 1, Folder 6, of the Archival Collections Administrative History Files, Archives Center, National Museum of American History; 1977 figures are from Szary, "Report on NMHT Manuscript Survey," (it is unclear why Szary's measurement of collections in Science \& Technology is low; it is possible that he was excluding Warshaw or some of the reference collections from his tally); 1978 figures are from MHT, Guide to Manuscript Collections; 1986 figures are from John Fleckner and Spencer Crew, "Archival Sources for Business History at the National Museum of American History," Business History Review, 60:3 (Autumn 1986), 474-486; and 2011 figures are from "Archives Center Collections Assessment," July 2011, sent to the author via e-mail by John Fleckner, September 9, 2011. 
NMAH's continuing interest in business and technology include acquisition of the records of the United Shoe Manufacturing Company (145 cubic feet, 1898-1987), the Hills Bros. Coffee Company (65 cubic feet, 1875-1965), the Simmons Mattress Company (88 cubic feet, 1892-2000), and the Bobcat Company (56 cubic feet, 1940s-2009).

\section{Commentary and Conclusions}

Historical manuscripts had been collected by the Smithsonian Institution from its establishment in 1846, though in random fashion and usually in association with object collections. Curators involved in planning the Museum of History and Technology following its authorization in 1954 rapidly expanded manuscript collecting, and continued, albeit at a somewhat slower pace, well past the opening of its physical museum structure in 1964, culminating with the acquisition of the Warshaw collection in 1967. Particular growth occurred with manuscripts relating to the history of science and technology, partly due to the difficulty in designing museum displays for large objects such as blast furnaces, bridges, and steamships. The publication of a collection guide in 1978 provided the first comprehensive listing of the archival collections held by MHT and confirmed that the national museum was one of a very small group of manuscript repositories focusing on business, industrial, and technological history.

Even in 1980, however, MHT employed no archivists, had no dedicated archival storage facility, and relied on a fourteen-year-old memo to define its manuscript collecting policy. In 1982, responding to both internal and external pressures, MHT finally created a dedicated space for archival materials and, in 1983, hired its first experienced archivist, establishing its Archives Center as an operating archival repository.

In contrast to Baker and Hagley, the Smithsonian's industrial manuscript holdings were gathered by museum curators with no formal archival training who were unaware of developing archival theory. As a result, occasional manuscripts were gathered alongside printed advertising, trade literature, and other historical scholarship into "reference collections" with little provenance to their origins. Robert Vogel, Barney Finn, and Jack 
White, the three curators most closely associated with industrial and technological manuscripts at MHT, were historian-curators, some holding graduate degrees, but all bearing experience from relevant fields of industrial practice. They tended to collect materials relating to their personal research interests. Vogel's acquisition of extensive holdings on steam engines, boilers, and other prime movers provides a prime example. While they preserved a considerable amount of valuable manuscript material, the curators' ignorance of archival practice - and the priority given to manuscripts that informed an individual curator's research and exhibit design - encouraged curators to split collections or to "cherry pick" just the few specific documents they needed.

These three key collecting curators were not without their detractors, and they encountered tensions with other staff seeking to impose limits to their acquisition activity, much like the tensions that developed at both Baker and Hagley. Rather than debating temporal or geographic boundaries as discussed at the other institutions, however, MHT curators debated the general place of manuscript acquisitions in the Museum's mission. The growth of manuscript holdings at MHT created needs for space, specialized types of arrangement and description, and staff skills which increasingly competed with the traditional priorities of an exhibit- and research-driven museum enterprise.

MHT's directors and other administrators were unsure how to control collecting activities and remained largely nonresponsive to the identified "archive problem" for nearly thirty years. This allowed curators significant autonomy in their collecting activities, particularly in the "golden era" between 1954 and the late 1960s when budgets for the new museum and its exhibits supported travel, supplies, and in some cases purchase of manuscript collections. Although a number of initiatives and "collections committees" suggested policies for the growing archival collection - and systems for review and approval of new acquisitions - the general lack of oversight through 1980 allowed individuals like Vogel, Finn, and White to continue acquiring materials as declining budgets might allow.

It is clear that MHT did not enter into manuscript collecting deliberately. Unlike Baker and Hagley, the institution's primary mission was that of a museum of history and 
technology, with no initial mandate to collect, preserve, and provide public access to an archival research collection. First and foremost, curators believed they were preserving materials which would otherwise be lost, items which other repositories, including the Library of Congress and the National Archives, would not value and select for permanent retention. Curators often claimed a relation between manuscript acquisitions and curators' needs for research, publication, and exhibit development, and gathered large internal "reference collections" and "information files," much like an academic historian or other scholar might amass during a professional career.

It is certain that archival material was necessary for understanding and documenting large objects and structures, particularly in topical areas such as transportation, mechanical engineering, and civil engineering. Through the late 1970s, other disciplines within the Museum, such as the Division of Ceramics and Glass or the Division of Numismatics, gathered only minimal information files and collected very few manuscript items. They did not see manuscript collecting activity as an active or integral part of their material culture collections. Although some documents were occasionally used as illustrations in exhibit settings, archival items were not regularly utilized as artifacts in displays.

By the time of publication of the 1978 Guide, MHT's manuscript collection included 350 collections measuring less than 5,000 cubic feet. This was much smaller than the contemporary holdings of Baker Library (1,400 collections listed in the fourth edition of its Guide published in 1978) and Hagley (more than 30,000 cubic feet referenced in its 1978 Guide). Most of the individual collections were smaller than those at Baker and Hagley; fewer than forty collections measured over 25 cubic feet, and only seven were larger than 100 cubic feet. The largest, the Warshaw Collection of Business American (measuring more than 1,000 cubic feet), was an anomaly. Lacking a logical home in any specific department or division, it remained largely unprocessed for several decades. The comparatively smaller size of individual collections is partly a reflection of the selectivity that curators such as Vogel, Finn, and White often applied in the field. As a museum of technology, curators were often primarily interested in engineering drawings, laboratory notebooks, and photographic material. They shied away from 
administrative correspondence, accounting records, and other types of "office files" - and openly referred such materials to repositories such as Baker Library. These selection decisions shaped the content of specific collections and influenced the types of questions which the preserved manuscripts might answer. ${ }^{440}$

By 1983, MHT had established itself as a key archival repository for records of science, technology, and industry. Its development represented yet another permutation of collecting in this topic area alongside Baker and Hagley. At Baker, collecting initially focused on the financial side of business and industry in support of an academic program. Hagley's directors collected the papers of business and industry more widely, in terms of both format and industrial sectors, and with more independence. At MHT, the research needs of a curatorial staff in a museum dedicated to the history of technology and science guided a somewhat disjointed manuscript acquisitions activity, but one centered more on technological hardware and records like blueprints and machinery tests than financial ledgers.

Like those at Baker and Hagley, MHT's collections eventually reached a period of stabilization as space limitations strongly influenced the transition from rapid expansion to maturity. After 1983, however, the preeminence of industrial and technological history in the nation's premier federal history museum had passed. Although technology remains an important topic of study and interpretation, John Fleckner noted that many of the collections he acquired in later years concerned

\footnotetext{
440 There is no easy way to compare collections, as each repository recorded and measured its collections differently and often failed to convert bound accounting volumes into linear or cubic footage. Baker Library provided discrete collection descriptions, but no aggregate total. John Riggs at Hagley tended toward counting discrete items; in 1978 he indicated total holdings over six million items, which the author has conservatively converted at a rate of 175 items per linear foot (to be inclusive of bound volumes). John Fleckner reported in 1986 that their 242 collections measured an estimated 4,500 cubic feet, but may have not included all of the curators' reference files. See Robert Lovett and Eleanor Bishop, Manuscripts in Baker Library: A Guide to Sources for Business, Economic, and Social History (Boston: Baker Library, 1978); John Riggs, A Guide to Manuscripts in the Eleutherian Mills Historical Library: Supplement Containing Accessions for the Years 1966 through 1975 (Greenville, Delaware: Eleutherian Mills Historical Library, 1978); and John Fleckner and Spencer Crew, "Archival Sources for Business History at the National Museum of American History," Business History Review, 60:3 (Autumn 1986), 475. For standard conversion figures see "Paper and Image Calculator" at https://www.ilmcorp.com/tools-and-resources/estimate-the-number-of-pages-or-images/ accessed June 10, 2017.
} 
"marketing of the product [and] the development of a brand identity" in the American consumer market. Although archival materials accompanied samples of coffee cans, mattresses, and machinery acquired by NMAH, manuscript assemblages now tended more toward promotional, advertising, and sales records. The NMAH's 2011 assessment of manuscript holdings for its current "Division of Work and Industry" - which includes the former units curated by Vogel, Finn, White, and others in the history of technology indicates that they comprise only a third of the manuscript holdings of the NMAH's Archives Center. Although no longer a focused archive of industrial and technological materials, the manuscripts held by the Smithsonian Institution's former Museum of History and Technology remain a critical resource to our understanding of the nation's industrial and technological heritage. The efforts of the early MHT curators, with their unique perspsectives, ensured that much more than just George Washington's letters or notebooks would be preserved as part of the United States' national history museum. ${ }^{441}$

441 “Archives Center Collections Assessment,” July 2011. 


\section{CHAPTER 5. FOUNDING AND EARLY DEVELOPMENT OF MANUSCRIPT COLLECTIONS AT THE BENSON FORD RESEARCH CENTER, THE HENRY FORD DEARBORN, MICHIGAN, 1905-1983}

\section{Introduction}

The manuscripts preserved at the Benson Ford Research Center at The Henry Ford in Dearborn, Michigan, represent, according to one historian, a "premier collection of available research material on an American business," with 1,800 accessions comprising 46,000 cubic linear feet of records. These materials were initially collected through two separate streams: (1) the Edison Institute, created by automotive industrialist Henry Ford in 1929 and comprising a museum, an open air living history museum (known as Greenfield Village), a grade school, and the Institute's library which contained a small manuscript collection; and (2) the corporate archives of the Ford Motor Company, begun in 1950 as only the third formal business archives in the United States. The collections from these two streams merged at the Dearborn museum location in 1964 and are presently housed in the Benson Ford Research Center. ${ }^{442}$

Throughout their development, the various Ford collections operated under a confusing variety of unit, divisional, and institutional names, but they are currently united at the Benson Ford Research Center (BFRC), a unit of The Henry Ford, the current brand name for the museum, Greenfield Village, and the research center. For ease of reference, this chapter will use informal naming conventions, such as the Museum, its Library, and the Village. Similarly, the Ford Motor Company will be referred to as "the Company," although its official corporate name also varied over time. ${ }^{443}$

\footnotetext{
${ }^{442}$ Quoted section is from Jeanine Head, "From Corporation to Museum: The Evolution of the Ford Archives," master's thesis, Wayne State University, 1987, 6. Information about extent of collections is from Benson Ford Research Center (BFRC) archivist Brian Wilson, personal communication, July 25, 2017.

${ }^{443}$ A page is devoted to name changes at the Museum and Village in Judith Endelman, Wendy Metros, and Jeanine Head Miller, Telling America's Story: A History of the Henry Ford (Virginia Beach, Va.: Donning Co. Publishers, 2010), 97.
} 
As one former archivist stated, "It is all tied up in Henry Ford." Ford played a central role in creating and nurturing both of the manuscript collecting streams. The resulting collections include business records of the international industrial firm he built, personal papers of his own life and of those of his family members, and historical materials gathered by the Edison Institute of Technology to support its Museum, Village, and other varied cultural missions. ${ }^{444}$

This chapter draws from a variety of source information, including publicly accessible administrative records of individuals responsible for the manuscript resources. Guides and inventories to the collections, both published and unpublished, furnish snapshots of the collections and allow one to track both additions and removals. Unfortunately, the author was not permitted access to internal donor information, accession records, or formal collecting plans. Oral interviews with current and former archivists, however, provide insight into acquisition and deaccessioning decisions. Additional historical sources include the reminiscences of Winthrop Sears, an early archivist for the Ford Archives, a handful of published articles by others associated with the repositories, and a 1987 master's thesis by historian and current Henry Ford Museum curator Jeanine Head. ${ }^{445}$

While the early history of Baker, Hagley, and Smithsonian's MHT could be categorized in three periods - creation, rapid growth, and maturity - this simple periodization cannot be applied to the Benson Ford Research Center. Thus, we will look at the two streams that eventually converged to become the Benson Ford - the Edison Institute and the Ford Archives - but pay particular attention to the Ford Archives, for after its period of rapid growth, the public Ford Archives did not enter into a period of maturity but was, instead, threatened with dismantling.

\footnotetext{
${ }^{444}$ Quoted section is from Cynthia Read Miller, personal interview, August 12, 2016.

445 The majority of sources are from the collections of the Benson Ford Research Center, The Henry Ford (hereafter abbreviated as BFRC). "Oral Reminiscence of Winthrop Sears Jr. Concerning the Henry Ford Archives in the 1950's and 1960's as told to Ann Flowers, one of his daughters," unpublished transcript, 1996, BFRC; Head, "From Corporation to Museum," 5; and Elizabeth Adkins "A History of the Ford Motor Company Archives, with Reflections on Archival Documentation of Ford of Europe's History," in Hubert Bonin et al., eds., Ford, 1903-2003: The European History (Paris: P.L.A.G.E.: 2003), 27-67.
} 


\section{Creation of Manuscript Collections at the Edison Institute, 1905-1964}

Henry Ford is the central figure in the manuscript collections preserved at the Benson Ford Research Center in Dearborn, Michigan, much as the collections at Hagley are linked to the personal and industrial life of P.S. du Pont. Born to a farming family in Dearborn in 1863, Ford was mechanically minded from a young age. Exposed to the machinery of his father's relatively modernized farm, Ford became an apprentice machinist in Detroit. Successive positions, including work with the Edison Illuminating Company, exposed the young man to machinery and processes of all types - steam engines, streetcars, and casting brass and bronze engine parts. Drawn to the concept of a self-propelled automobile, Ford built a gasoline engine from scratch in his home workshop and built his first "quadricycle" in 1896. His interest in building, selling, and racing automobiles soon led to employment by several fledgling automotive companies in Detroit. ${ }^{446}$

Ford incorporated The Ford Motor Company on June 16, 1903, and began limited production of vehicles. Experimenting with everything from engine block alloys to leaf springs and assembly techniques, Ford sought to produce a reliable automobile at a price accessible to a large portion of the population. What resulted was Ford's Model T, which began production in 1908. By 1920, Model Ts made up more than half of all automobiles on American roads. The success of the vehicle was predicated on a variety of new systems created, adopted, and/or adapted by Henry Ford and the Ford Motor Company, including the use of time-motion studies, a moving assembly line, a $\$ 5$ day wage scale, and other elements of mass production and mass consumption. This system evolved through production techniques developed at his factories on Detroit's Mack and Piquette Avenues, but more fully integrated in a wholly new complex built in Highland Park. "In the dozen years 1903-1915," historian and Ford biographer Allan Nevins wrote, "the

\footnotetext{
${ }^{446}$ Allan Nevins, Ford: The Times, the Man, the Company (New York: Charles Scribner's Sons, 1954), 74118, 154-162, 192-219; and James Wamsley, American Ingenuity: Henry Ford Museum and Greenfield Village (New York: Henry Abrams, 1985), 15, 157, 159.
} 
Ford Motor Company had written one of the most brilliant chapters of modern industrial history." 447

Outside the Company, however, Henry Ford maintained a keen interest in the history of mechanical and decorative arts and began to collect items in those areas. Early, he developed a collection of watches and clocks. Around 1905, Ford began to purchase materials relating to the life of his mentor and friend, Thomas Edison. Henry Ford developed a nostalgic love for the American past - a past that he had lived on the family's Dearborn farm - and one inspired by the wholesome messages he found in the Eclectic Readers published by William Holmes McGuffey between 1836 and 1920. Designed as early elementary school texts, the McGuffey readers became another one of Ford's collecting passions. Unable to easily locate the volumes, Ford began a search for the primers and eventually gathered more than 468 copies of 145 different editions from book dealers and manuscript collectors across the country. Henry Ford's interest in Americana, however, was also rooted in mechanical objects - machines which showed the progress and genius of the American people. By 1912, he was collecting larger mechanical objects such as wagons and threshing machines. Having ascended into the wealthy industrial elite, Henry Ford had the means to feed his collecting interests. His collecting (and collections) grew to include steam engines, tractors, and stoves, as well as smaller household items such as radios, appliances, and other inventions which changed people's everyday lives. ${ }^{448}$

Ford was dissatisfied with prevailing forms of historical teaching and interpretation. Writing and publishing scholarly books - and expecting that regular people would read them - failed, in his view, to engender interest and learning about the past (his "history is more or less bunk" comments were directed toward these

\footnotetext{
${ }^{447}$ Quoted section is from Nevins, Ford: The Times, the Man, the Company, 237. See also Wamsley, American Ingenuity, 166-167.

${ }^{448}$ Telling America's Story, 15-16; Wamsley, American Ingenuity, 17; and Geoffrey Upward, A Home for Our Heritage: The Building and Growth of Greenfield Village and Henry Ford Museum, 1929-1979 (Dearborn, Michigan: Henry Ford Museum Press, 1979), 2.
} 
practitioners). Ford cared little for traditional renderings of the past and cared even less

for historians and their varying interpretations of history. ${ }^{449}$

Ford believed one could more effectively show history through objects, buildings, and real stories of human experience, than through scholarly publications. It was an approach of "learning by doing," he stated, for "by looking at things that people used and that show the way they lived, a better and truer impression can be gained than could be had in a month of reading." 450

Besides the machines and smaller artifacts he was gathering, Ford believed another important avenue for such "truer impressions" was the preservation and/or reconstruction of historic buildings. In 1919, Ford moved and restored his own childhood home, piquing his passion for locating authentic antiques to furnish the interior. He developed a deep interest in traditional arts and hand crafts, wishing to replicate and demonstrate traditional methods and early manual production techniques which were passing from general knowledge (ironically, because of the industrial mechanization of firms such as the Ford Motor Company). ${ }^{451}$

As early as 1919, Henry Ford began to speak of his desire to create a place to manifest his ideas about teaching history.

We're going to start something. I'm going to start up a museum and give people a true picture of the development of the country. That's the only history that is worth observing, that you can preserve in itself. We're going to build a museum that's going to show industrial history, and it won't be bunk! We'll show the people what actually existed in years gone by and we'll show the actual development of American industry from the early days, from the earliest days that we can recollect up to the present day. ${ }^{452}$

Ford increased his tempo of collecting for the museum project. He assembled a team of agents and Company executives who traveled the country seeking material for his

\footnotetext{
${ }^{449}$ Upward, A Home for Our Heritage, 2; Telling America's Story, 16; and Steven Watts, The People's Tycoon: Henry Ford and the American Century (New York: Knopf, 2006), 423.

${ }^{450}$ Watts, The People's Tycoon, 423. Quoted section is included in Telling America's Story, 116-17, and Upward, A Home for Our Heritage, 154.

${ }^{451}$ Watts, The People's Tycoon, 403; and Telling America's Story, 19.

452 This uncredited quote appears in several places, including Wamsley, American Ingenuity, 27, and Upward, A Home for Our Heritage, 3.
} 
growing collection. "His taste was more enthusiastic than expert," one writer described, "but as sheer accumulator he had no peer." Rather than focusing on high style materials of America's landed gentry, Ford collected humble, everyday objects which "add depth and meaning to the story of America's development." Ford did not seek the sort of systematic or ordered collection meticulously amassed by museum curators to define a theme, but instead sought "something of everything." In a short span of time, Ford became one of the single greatest collectors of Americana in American history. ${ }^{453}$

At the same time, Ford's interest in historic buildings grew. In 1923, he bought the Wayside Inn in Sudbury, Massachusetts, which was constructed in 1686 and profiled by American poet Henry Wadsworth Longfellow. The resulting project - including restoration and furnishing of nearby period buildings, rerouting a busy highway, and establishing public tours with historical interpreters - was the precursor to the fully functioning open air museum he would develop in Michigan. Ford replicated the experience closer to home in 1924 when he purchased the 1836 Botsford Tavern just west of Detroit. ${ }^{454}$

These varying strands came together in 1925 when Ford established the Edison Institute of Technology, in honor of his mentor and friend Thomas Edison. The Institute was formed to administer a museum that would tell the story of man's technological and cultural progress, utilizing comprehensive displays of inventions and artifacts. It would also operate an adjacent open air village containing the buildings he was collecting; the village would help bring the Museum's artifacts to life by "recreating for visitors the real, lived conditions of the American past." Greenfield Village, as it became known, was a created community of relocated and renovated historic structures from around the world,

\footnotetext{
${ }^{453}$ Quoted section is from Sidney Olson, Young Henry Ford: A Picture History of the First Forty Years (Detroit: Wayne State University Press, 1997), 1. See also Watts, The People's Tycoon, 404, 409; Upward, A Home for Our Heritage, 3; and Telling America's Story, 23. A good description of Ford's network of agents is in Watts, The People's Tycoon, 404-406.

${ }^{454}$ Upward, A Home for Our Heritage, 3; Wamsley, American Ingenuity, 17; Telling America's Story, 20; and Watts, The People's Tycoon, 404.
} 
each filled with artifacts put into use by interpretive staff who had learned traditional crafts, such as pottery, printing, and glass-blowing. ${ }^{455}$

In 1926, Ford selected a site in Dearborn for the project; it was adjacent to the Ford Motor Company Engineering Laboratory and close to his own residence, a mansion he and wife, Clara, had built on the upper Rouge River and named Fair Lane. As the foundations were laid for the Museum on September 27, 1928, the Village opened. It would take another year to complete the Museum and install additional buildings in the Village, including a meticulous reconstruction of Thomas Edison's Menlo Park laboratory based upon original drawings and photographs Ford had collected. ${ }^{456}$

A formal, public dedication of initial exhibits in the Edison Institute Museum and Greenfield Village was held on October 21, 1929, to coincide with the $50^{\text {th }}$ anniversary of Edison's invention of the light bulb. Work on the two facilities was ongoing; the Village, which comprised 30 buildings in 1929, expanded to 68 structures by 1940, with another 20 added before Henry Ford's death in 1947. The Village employed more than 30 fulltime artisans and craftsmen, demonstrating pottery, spinning and knitting, glassblowing, farming techniques, and blacksmith work. It took workers until after 1940 to complete the Museum and its more than 350,000 square feet of exhibition space. ${ }^{457}$

The Museum and Village became a central part of Ford's life, and he often spent more time there than in any of his Company offices. He personally managed the project and avoided the employment of museum professionals who did not align with his ideas. "In all areas the driving force and only true management came from Henry Ford himself," historian Geoffrey Upward wrote, "Both facilities grew solely from his ideas." 458

\footnotetext{
455 Quoted section is from Watts, The People's Tycoon, 410. See also Upward, A Home for Our Heritage, 21.

${ }^{456}$ Upward, A Home for Our Heritage, 21, 35; and Wamsley, American Ingenuity, 17.

${ }^{457}$ Upward, A Home for Our Heritage, 58-66, 77; Wamsley, American Ingenuity, 19; Watts, The People's Tycoon, 405; and Telling America's Story, 53..

458 Watts, The People's Tycoon, 409; Upward, A Home for Our Heritage, 77; Telling America's Story, 56, 79; and "History of the Ford Archives," typescript chronology in Archives Vertical File titled "Sears Chronology," BFRC.
} 
While Henry Ford's obsessive collecting extended from steam irons to steam locomotives and from miniature patent models to full-size buildings, manuscript items and printed items often came with them. His passion for McGuffey Readers formed the nucleus of a growing a library collection, and he collected rare books and manuscripts in a haphazard fashion alongside artifacts and buildings. Museum librarian Jerome Smith claimed the resulting collection was comparable to E.D. Church's on the discovery of the Americas and their early history (now part of the Huntington Library), John Carter Brown's New World materials (now at Brown University), and William Clements' colonial collections (in the library bearing his name at the University of Michigan). ${ }^{459}$

Ford's small but growing collection of manuscript items was housed alongside print materials in the Museum library. Although little evidence of a distinct physical space survives, references to a Museum Library appear as early as 1935. A December 1937 article describing the opening of a new multipurpose building for the Edison Institute School, a K-12 school operating on the Village grounds, includes a photograph and description of a school library. The building, which became known as Lovett Hall, would house the expanding library collections until $1980 .{ }^{460}$

Like curators at Smithsonian's Museum of History and Technology, curators in the Museum and Village gathered manuscripts and gray literature to identify, verify, and interpret their artifacts. Manuscript material, photographs, and printed matter were often acquired with specific artifacts for the Museum and with the historic structures relocated to the Village, as was the case with the 1936 purchase of the Wright Brothers Cycle

\footnotetext{
459 Jerome Smith references a children's song in the McGuffey as "the rhyme that started a search that started a collection that started a Library that started a Museum that eventually lay in The Edison Institute that Henry Ford built in honor of his friend, Thomas Alva Edison." See Jerome Smith, "Robert Hudson Tannahill Research Library," The Herald (publication of The Edison Institute), 3:3 (July 1974), 3, 5; Wamsley, American Ingenuity, 25; Telling America's Story, 187;

460 J.A. Humberstone, "Conditions of Books in Museum Library," attached with memo from Humberstone to F.L. Black, March 4, 1935, Box 2, Accession E.I. \#156, Henry Ford Museum Planning and Construction Records, BFRC; "The Edison Institute's New Building," The Herald (publication of The Edison Institute), 4:23 (December 10, 1937), 1; Lighting fixtures and paneling in the photo match those in a 1937 photograph of Henry Ford and author H.G. Wells in the "Lovett Library." Image 108537, BFRC, https://www.thehenryford.org/collections-and-research/digitalcollections/artifact/110359\#slide=gs-263007 accessed January 21, 2017.
} 
Shop. Staff also maintained collections of books and documents pertinent to their individual research areas or to help document specific buildings and artifacts (though never to the extent of a curator such as Robert Vogel at Smithsonian). ${ }^{461}$

Historian Jeanine Head noted there was little attempt to systematize the records of the Museum organization and its component parts:

... documentation on village structures was held by the museum library, the registrar's office, and in the files of the historical architect. Administrative records were squirreled away in basements and other out-of-the-way storage areas. Although the [library] had acquired some material on an informal basis over the years, records were scattered throughout museum offices. ${ }^{462}$

A representative example are two boxes of material relating to the Armington and Sims machine shop building, constructed at the Village in 1929. The building was not a historic structure, but was designed by Village curators to represent the workings of a typical belt-driven machine shop of the period around 1875. To support the design and fabrication, the Library acquired a collection of records and catalogs from the firm of Armington \& Sims (3 cubic feet, 1884-1928, E.I. Accession 87), which were later incorporated into a larger and ever-expanding collection relating to each of the structures in Greenfield Village (E.I. Accession 186). The two boxes currently retained for Armington and Sims, for instance, include original historical photographs of machine inventors Pardon Armington and Gardner Sims, extant catalogs of the engines they manufactured, and correspondence of Village designer Edward Cutler about the 1929 design and construction project, as well as more recent material like John Bowditch's 1983 conference paper for the Society for Industrial Archeology, and a 2013 report from a graduate student who surveyed equipment associated with the building. ${ }^{463}$

Many original manuscript and printed items were incorporated into public displays. "Exhibition libraries" installed within the Village's historic buildings contained

${ }^{461}$ Smith, "Robert Hudson Tannahill Research Library," 3. See finding aid for the Wright Brothers Collection, Accession 1623 https://www.thehenryford.org/collectionImg/pdf/82-300-1623-

0/WrightBrothersCollection_Accession1623.pdf accessed January 22, 2017.

${ }^{462}$ Head, "From Corporation to Museum," 43.

463 "Armington \& Sims," boxes 1 and 2, Edison Institute Accession 186, and related photographs in Box 25, E.I. Accession \#1929, Edison Institute Photographs, BFRC. 
the actual books once owned and read by the people associated with the buildings, such as the Wright brothers' home and several other historic offices and workshops. The Heinz House staged actual ledgers and booklets on desks, and displayed original photographs depicting bottling processes, factory workers, and advertisements for the 57 Varieties. Portions of other Village buildings served as storage rooms: 200 linear feet of records from the Ford Motor Company, for instance, were stacked in the loft of the reconstructed Mack Avenue plant in Greenfield Village. ${ }^{464}$

There are indications that the Museum's library function was staffed with professionally-trained librarians by the 1950s. Kenneth Metcalf joined the Museum in 1954, following work in the Burton Historical Collections and as a reference librarian in the history and travel department at the Detroit Public Library. He held bachelors and master's degrees from Wayne State University, as well as a master's degree in library science from the University of Michigan. Although it is difficult to gage the work he accomplished at the Museum Library, there is evidence of Metcalf's professional activity with the Special Libraries Association and the Historical Society of Michigan. Sadly, Metcalf and his wife were killed in an automobile accident in September 1965, just months after he had been elevated to Deputy Archivist and Librarian. ${ }^{465}$

Even with a professional librarian, however, little was done to organize, describe, or make accessible the large amount of manuscript items. Jerome Smith, who was hired as a librarian in 1966, discovered manuscript items "stuffed in folders ... identified by the

\footnotetext{
${ }^{464}$ Smith, "Robert Hudson Tannahill Research Library," 5, 37; Henry Edmunds to H.S. Ablewhite, "Records from the Office of Henry Ford," January 7, 1953, Box 33, Accession 506, BFRC. Some of these materials were ultimately ordered returned to the Company when the Ford Archives were being developed at Fair Lane. Reference is made to materials removed in 1952 from the Museum to the Archives in a letter from Donald Shelley to William Clay Ford, May 20, 1963, folder labeled "Archives Lists," Box 1, E.I. Accession \#57, BFRC.

465 "The Shelley Years - 1954-1975," typescript document in "Shelley, Donald," Archives Vertical Files, BFRC. "Kenneth M. Metcalf," Chronicle (the newsletter of the Historical Society of Michigan), 2:6 (October 1965), 2. "Kenneth M. Metcalf," Bulletin of the Special Libraries Association, Michigan Chapter," 31:2 (December 1965), 1-2.
} 
most ambiguous titles." Nothing had been cataloged in any professional manner and it became a "hunt, pick, and guess system to locate anything."466

Glimpses of the Edison Institute's manuscript holdings are provided by a 1963 memo from Kenneth Metcalf to Donald Shelley, outlining business papers held by the Library, and by an article by librarian Jerome Smith in the July 1974 issue of The Herald, a magazine distributed to friends of Greenfield Village. Although specific dates for individual accessions cannot be discerned, the memo and article mention specific collections which survive today at the Benson Ford Research Center. These include the Autocar Company records (107 cubic feet, 1897-1932, Accession 424), the Thomas A. Edison Collection (53.6 cubic feet, 1860-1980, Accession 1630), the Boston and Sandwich Glass Company records (1.6 cubic feet, 1825-1892, Accession 00.1838), the H. J. Heinz Company records (2.7 cubic feet, 1874-1990, Accession 53.41), and a small Noah Webster Collection (0.1 cubic feet, 1788-1886, Accession 00.1422). ${ }^{467}$

Oddly, neither source mentions one significant collection acquired by the Museum in the 1930s: photographic images by William Henry Jackson and the Detroit Publishing Company (17.2 cubic feet and 46 oversize boxes, 1880-1936). Jackson's images of the American West made him the nation's most famous travel photographer. The Detroit Publishing Company was created to promote and distribute images documenting life in the Americas in the late nineteenth and early twentieth centuries. The Museum had acquired Jackson's original negatives and prints from the estate of Robert B. Livingstone in 1937. Jackson's son convinced the Museum to donate the negatives to the Colorado Historical Society, which split the collection with the Library of Congress in 1949. The Museum retained 30,000 photographic prints, 15,000 postcards, and 5,000

\footnotetext{
${ }^{466}$ Smith, "Preliminary Guide to the Manuscript Collections in the Robert H. Tannahill Research Library, Greenfield Village and Henry Ford Museum," (ii-iii), undated typescript inventory, Reading Room Reference Collection, BFRC.

${ }^{467}$ Some collections described in the two lists don't easily map to existing collections, such as the Loomis Machine Company records, account books for a series of iron furnaces in Pennsylvania, collections relating to the Michigan Cycle Company, and "many volumes of penned correspondence" of agricultural machinery manufacturer D.S. Morgan and Company. Kenneth Metcalf to Donald Shelley, May 21, 1963, Box 1, E.I, Accession \#57, BFRC; Smith, "Robert Hudson Tannahill Research Library," 2-37; Autocar is included in Richard Ruddell to Henry Edmunds, "Reduction of Archives' Holdings," July 24, 1956, Box 33, Accession 506, BFRC.
} 
color and sepia prints, and it remains one of the most important acquisitions of this early period. ${ }^{468}$

Henry Ford's death in 1947 was a significant blow to the Museum and Village.

His close oversight and management of the two facilities had nurtured their programs, but his distrust of trained historians had also kept the operations from developing the professional staffing and managerial structures used in museums of similar size and scope. "[Mr. Ford] expected someday to leave," remarked Roy Schumann, an Edison Institute employee, "Just how he thought it was going to be carried on, I don't know." The Museum and Village had not operated profitably; while Ford had covered shortfalls from his personal fortune, he made no arrangements in his will to fund its ongoing operations. Henry's widow, Clara Ford, looked in on the project with regularity, but her death in September 1950 was the catalyst for more significant action. She had bequeathed $\$ 4$ million to the Edison Institute at the time of her death, but the venture would need to be self-supporting moving forward. ${ }^{469}$

In September 1950, A.K. Mills was appointed as executive director for both Greenfield Village and the Edison Institute Museum. A personal friend of Henry Ford, Mills had served as director of public and employee relations for the Ford Motor Company. He had been involved with the Wayside and Botsford Inn projects and had worked with Henry Ford on other aspects of Greenfield Village. Mills had been selected by the Ford family and the Ford Motor Company a year earlier to coordinate a variety of projects planned for 1953 to mark the $50^{\text {th }}$ anniversary of the Ford Motor Company's founding (described in greater detail below). ${ }^{470}$

The fortunes of the Museum's small manuscript collection and library function ebbed and flowed through 1964. During the 1953 celebrations, the Museum adopted a new public name, The Henry Ford Museum, while continuing alongside Greenfield

\footnotetext{
${ }^{468}$ Finding aid for the Detroit Publishing Company Collection, Accession 37.102, BFRC, accessed 11-2816, http://www.dalnet.lib.mi.us/henryford/docs/DetroitPublishingCompanyCollection_Accession37102.pdf. See also "Photographer to the World," accessed 11-28-16, http://ophelia.sdsu.edu:8080/henryford_org/12-08-2013/exhibits/dpc/everyday/about.asp.html ${ }^{469}$ Quoted section is from Telling America's Story, 83. Additional material from 87-88.

470 "History of the Ford Archives," typescript chronology. The date of Mills' appointment is given as January 1951 in Telling America's Story, 88. See also "Oral Reminiscence of Winthrop Sears," [1].
} 
Village under the umbrella Edison Institute. Following Mills' unexpected death in 1954, Donald Shelley, a curator of fine arts, moved into the executive director's role and began a process of reevaluation and assessment to restructure the operations as a stand-alone, nonprofit cultural institution. Members of the Ford family continued their support in a "lay leadership" role as members of the Museum's Board of Trustees. Although the manuscript collections failed to grow in significance, the Edison Institute's museum and Greenfield Village components enjoyed increased public success, with annual visitation topping 1 million by $1960 .{ }^{471}$

\section{Creation and Rapid Expansion of the Ford Motor Company Archives, 1950-1954}

The small assortment of manuscripts collected by the Edison Institute was only one of the two streams that eventually merged to create what is now the Benson Ford Research Center. The other, much larger collection of records, originated as the internal corporate archives of the Ford Motor Company. Ford archivist Henry Edmunds noted that the Ford Motor Company Archives, "like a number of other industrial archives, owes its establishment primarily to an anniversary." Similar to the efforts at Hagley to develop a museum in honor of DuPont's $150^{\text {th }}$ anniversary in 1952, the Ford Motor Company Archives was created in 1951 in preparation for the Company's 50 $50^{\text {th }}$ anniversary celebration in $1953 .^{472}$

As early as the 1920s, the Company became increasingly aware of the role that its own history could play in promotion and marketing. As Model T production reached its zenith, the Company embarked on its most ambitious project: the creation of a huge selfcontained factory complex along Detroit's Rouge River to replace the Highland Park factory, which had reached its peak capacity for production. Supplied with raw materials from Ford-owned iron mines and timber tracts in Wisconsin and Michigan's Upper

\footnotetext{
471 “The Shelley Years;" Telling America's Story, 88; and Upward, A Home for Our Heritage, 125, 138.

472 Quoted section is from Henry Edmunds, "The Ford Motor Company Archives," The American Archivist, 15:2 (April 1952), 99. See also "History of the Ford Archives," The Ford Archives (Dearborn, Michigan: Greenfield Village and Henry Ford Museum, 1974), 8.
} 
Peninsula, as well as a rubber plantation in Brazil, the resulting River Rouge plant became the world's largest industrial site and the largest vertically integrated manufacturing facility. It also heralded the introduction of the Model A automobile in 1927, Ford's first departure from production of just the Model T. ${ }^{473}$

Alongside its industrial development, the Company developed public exhibitions to highlight the new Rouge plant and the history of the Ford brand. These included a series of exhibits in a structure known as The Rotunda Building. Originally built for the 1933-34 Chicago World's Fair, the building was reassembled adjacent to the Ford headquarters building near the entrance to the River Rouge complex - and about four miles from the Museum and Village complex. The Rotunda opened in 1936 as a public exhibit center to share the Ford story and as a jumping-off spot for public tours of the Rouge manufacturing complex. The Rotunda would also become the first home of a Ford corporate archives. ${ }^{474}$

Following Henry Ford's death on April 7, 1947, the family and Company desired to celebrate his life and legacy. The Company's $50^{\text {th }}$ anniversary was also approaching in 1953, and many saw this milestone as the vehicle to focus attention on the life of Henry Ford. In May 1950, the initial outline of the potential celebrations began to take shape. ${ }^{475}$ In the summer of 1950, President Henry Ford II committed \$2 million to a threeyear project to mark the $50^{\text {th }}$ anniversary during the summer of 1953 . Company officials created a Fiftieth Anniversary Plans Office, selecting A.K. Mills to lead the effort. A graduate of the University of the Missouri School of Journalism, Mills had initially worked in aviation marketing and publicity. He represented Amelia Earhart, directed publicity for the first Byrd Antarctic Expedition, and later worked for Time, Inc., Life Magazine, and Earl Newsom \& Company. Mills came to Ford Motor Company and eventually served as director of Public and Employee Relations. He was involved in

\footnotetext{
473 Watts, The People's Tycoon, 366-375.

${ }^{474}$ Head, "From Corporation to Museum," 14; "History of the Ford Archives," typescript chronology; and Adkins, "A History of the Ford Motor Company Archives," 41.

475 "History of the Ford Archives," typescript chronology; Head, "From Corporation to Museum," 2; and Adkins, "A History of the Ford Motor Company Archives," 33.
} 
several of Henry Ford's history projects and had been appointed as director of the Edison Institute in $1950 .{ }^{476}$

Mills began to talk to others within and outside of the Company about the anniversary project - and how best to cement and celebrate Henry Ford's legacy. Among the elements Mills initiated was providing the Rotunda building (receiving a muchneeded facelift) with new exhibits to mark the progress of the Company over its first half century. The anniversary year would include banquet dinners for dealers; a pictorial book, Ford at Fifty; and an exhibit at the Henry Ford Museum celebrating the life of Henry Ford. An advertising campaign themed to "The American Road" included calendars featuring Norman Rockwell art, a national television show (a live two-hour "visurama"), and a documentary-style film, all extolling improvements in the American landscape, farming, work life, and society resulting from the development of the automobile industry (particularly the central role of the Ford Motor Company). The primary events would be coordinated for a full week around the actual June 16, 1953, anniversary date. ${ }^{477}$

One of the principal anniversary projects was the publication of a book about Henry Ford and the Ford Motor Company. "We believe that the book should be something more than a routine business history," Ford executive J.R. Davis wrote to Henry Ford II, noting that it "can present the true story of the Company and the tremendous effect it has had on the social, economic and industrial history of America." Correspondence with business historians encouraged the idea. Baker Library director and Harvard University historian Arthur Cole encouraged a frank and honest account. "[A]llow your historian to make as much of the company's errors and its capacity to

\footnotetext{
${ }^{476}$ Head, "From Corporation to Museum," 1; Adkins, "A History of the Ford Motor Company Archives," 33; "History of the Ford Archives," typescript chronology.

477 There are extensive records of the more general activities of the anniversary committees in a number of collections. See documents such as "A General Outline of Plans and Activities Prepared by the Executive Secretary, 50 ${ }^{\text {th }}$ Anniversary Committee," ca. May 1952, Box 2, Accession 506, BFRC. For advertising and the role of Ford dealers, see Fifty Years Forward, a booklet distributed to dealers describing the various anniversary-related promotions, Box 2, Accession 506, BFRC.
} 
overcome them," Cole wrote, "as well as the easier triumphs of technological or good marketing policies." 478

Mills realized that a definitive history could only be completed by an external historian with full access to as many sources as possible. Allan Nevins, a historian at Columbia University, was eventually selected from a pool of potential authors. A respected published historian, Nevins had helped to develop the emerging technique of oral history at Columbia and had received Pulitzer Prizes for his works on U.S. President Grover Cleveland and U.S. Secretary of State Hamilton Fish. Nevins knew the book project was uniquely situated to benefit from oral interviews with the numerous living individuals who had known and worked with Henry Ford. The project was envisioned as a combination history of the Ford Motor Company, history of the automotive industry in general, and biography of Henry Ford. Company officials, including Henry Ford II, experienced "a rather severe shock" when Nevins informed them of his six-year schedule to produce a two volume study. Nevins did not expect the first volume, which was eventually titled Ford: The Times, the Man, and the Company, to be completed until at least the latter part of 1954 - nearly a full year after the $50^{\text {th }}$ anniversary celebrations were completed. ${ }^{479}$

The book and other anniversary projects required access to a variety of records. And the Company quickly discovered that its institutional memory "was in bits and pieces, physically diffused through hundreds of files, in dozens of locations." Company

\footnotetext{
478 J.R. Davis to Henry Ford II, December 12, 1950, Box 2, Accession 506, BFRC; and Arthur Cole to A.K. Mills, December 13, 1950, Folder labeled "Harvard University," Box 3, Accession 506, BFRC.

${ }^{479}$ Allan Nevins and Frank Hill, Ford: The Times, the Man, and the Company (New York: Scribner, 1954). The subsequent volumes were published as Ford: Expansion and Challenge, 1915-1933 (New York: Scribner, 1957) and Ford: Decline and Rebirth, 1933-1962 (New York: Scribner, 1963). Quoted section about "shock" is from Adkins, "A History of the Ford Motor Company Archives," 32. The project was funded by a grant from the Ford Motor Company Fund to Columbia University, and produced under the guidance of an academic advisory committee, but Nevins and co-author Frank Hill controlled the content. The authors retained copyright for the final work, with royalties given to the University. Information about the book project is included in Head, "From Corporation to Museum," 15-16; Adkins, "A History of the Ford Motor Company Archives," 35-36; and Allan Nevins to A.K. Mills, September 7, 1951, Box 130, Accession 506, BFRC. See also the "Historical Note" in the finding aid to Accession 506, BFRC, http://www.dalnet.lib.mi.us/henryford/docs/MillsEdmundsAndNevinsAndHillSeries_Accession506.pdf accessed March 17, 2016
} 
officials realized that in order to present a clear, complete and true narrative of the history of the company, pertinent material would need to be gathered and organized. The concept of a central Company library was supported by the anniversary committee. "Henry Ford is destined to occupy an important niche in history," the committee stated. "The Ford Motor Company can best serve itself and the public interest by establishing ... a central library of information for writers and historians for years to come" (italics mine). While the initial thoughts about the book project and archives might have focused on a biographical account of Henry Ford's life, Mills and others soon realized that Ford's life was so interconnected with the Company that older corporate records would also be necessary. ${ }^{480}$

Regardless of providing Nevins a free hand in writing the book, the group also realized its responsibility to sift through sources - both manuscript and published - to establish known facts about Henry Ford's life. "Since Henry Ford was a controversial figure, and since no definitive biography is available," the anniversary committee stated, "much controversial and contradictory material is coming increasingly into print." The committee hoped the competent group of research people it was assembling could also check material published about Ford to establish items as either authentic or untrue. ${ }^{481}$

Locating historical records was not initially difficult. Within the Company, a variety of units had preserved corporate records. The Company even operated a records storage facility at its former Highland Park plant, though little detailed evidence exists of a formal records management program. A February 1949 executive communication issued by Ford Vice President Ernest Breech spoke of an urgent need to review and modernize records practices to address rising costs. "Storage areas formerly considered ample for the filing of records are now seriously overcrowded," he noted, "and the total investment in floor space, filing cabinets, and other facilities, is at the highest point in the

\footnotetext{
${ }^{480}$ Quoted section about "bits and pieces" is from Edmunds, "The Ford Motor Company Archives," 99; "Minutes of Meeting of Committee on 50 ${ }^{\text {th }}$ Anniversary of Company Held in the Office of Mr. J.R. Davis May 2, 1950," Box 52, Accession 506, BFRC; Head, "From Corporation to Museum," 2; Adkins, "A History of the Ford Motor Company Archives," 33.

481 "Minutes of Meeting of Committee on $50^{\text {th }}$ Anniversary of the Company Held in the office of Mr. J.R. Davis," May 2, 1950, Box 52, Accession 506, BFRC.
} 
Company's history.” Breech's memo clearly reflects the influence of records management practices, particularly the need to retain certain records permanently while destroying others once legal, tax, or audit requirements passed. Breech collected policies and standards for the storage of paper records issued by the National Archives. ${ }^{482}$

Company officials assigned the Controller's Office records administration responsibility in 1949, and by December 1950, a variety of staff and units was involved with internal records issues. These included those managing specific collections in the Company's legal files office, financial records vault, and inactive records facility at Highland Park, but also Company information held in the engineering library, the labor relations department, and the library, photographic, and motion picture departments within the Ford public relations department. Some references indicated that the Accounting Policies and Systems Department and other operating divisions had developed records retention schedules, but others indicate a lack of adequate controls over the inactive files being stored at the Highland Park facility. Older engineering drawings had been photographed at some point, with very few paper originals retained. ${ }^{483}$

As Mills' group began to familiarize itself with what records might be used for the anniversary projects, A.K. Mills himself sought advice on how to gather and manage the materials as an archives. He made two trips east, in October and November 1950, to visit repositories which he felt presented similarities in content, theme, or structure to the Ford project. Rather than focusing on the few existing private corporate archives at that time, Mills included a wide variety of institutions and archival professionals on his itineraries - an indication that his outcomes were directed more toward a public facility with records of national significance rather than a private corporate records center. He visited with Wayne Grover, Archivist of the United States; Luther Evans, Librarian of

\footnotetext{
${ }^{482}$ Head, "From Corporation to Museum," 6; and Memorandum from Ernest Breech, "Retention and Destruction of Business Records," February 14, 1949, folder labeled "Reducing Archival Holdings," Box 33, Accession 506, BFRC. Based upon this information, Ford later adopted a specially-made foil-clad archival box which was designed to withstand higher temperatures in the event of a fire.

${ }^{483}$ Specific staff are named in the appendix titled "List of Officials and Employees Interviewed" in Robert Bahmer, "Report on the Archives of the Ford Motor Company," December 15, 1950, Box 2, Accession 506, BFRC, 3, 6. See also C.E. Bosworth to V.Z. Brink and A.R. Miller, "Organization of Records Administration Activities," September 28, 1951, Box 33, Accession 506, BFRC; and Edmunds, "The Ford Motor Company Archives," 104.
} 
Congress; Paul Vanderbilt, curator of the prints and photographs division of the library of Congress; and Herman Kahn, Director of the Franklin Delano Roosevelt Library at Hyde Park (the first presidential library, designed and supported by Roosevelt in advance of the Presidential Libraries Act passed in 1955). Faculty at the Columbia University Library School cautioned against setting aspirations too high, referencing other family archives which were "presently hard-pressed for funds and are so specialized that they do not become part of an integrated general library."

Of particular note was his visit to Cambridge, Massachusetts, and his interactions with Arthur Cole and Donald Clark at Baker Library, as well as Thomas Navin, a professor in business history at Harvard University. "I know something of the work which you people have done pioneering in this field," Mills wrote to Cole. "I am not only anxious to see it, but to seek your advice as our plans begin to take shape.” Mills was particularly pleased to receive a copy of Cole's 1938 article from Library Quarterly, entitled "Business Manuscripts: Collection, Handling, and Cataloging." 485

Mills was interested in how best to structure and staff the overall project, including the archives, the book project, and other aspects of the anniversary work. He also sought input concerning who should lead the effort. Patricia Diver at Time/Life cautioned Mills to carefully consider the competing needs of the research/writing and the library/archives. "[L]ibrarians want to keep everything and very often are loath to release any of the material even when needed." Instead, she suggested, the project should be led by a research director who would coordinate the two projects and write the publication.

\footnotetext{
${ }^{484}$ Mills corresponded with the Illinois Historical Society, the William Clements Library at the University of Michigan, the Carnegie Foundation archives, the Thomas A. Edison Collection, librarians at Yale University, and Stanley Pargellis at Chicago's Newberry Library. See "Draft," A.K. Mills, September 18, 1950, Box 3, Accession 506, BFRC. "Draft," A.K. Mills, September 18, 1950, Box 3, Accession 506, BFRC (summaries of the information Mills received from each office are in this same location); A.K. Mills to Stanley Pargellis, October 31, 1950, folder labeled "Harvard University," Box 3, Accession 506, BFRC; Head, "From Corporation to Museum," 5; "Notes," September 7, 1950, Box 3, Accession 506, BFRC; "Columbia University Library School," October 10, 1950, Box 3, Accession 506, BFRC; and "Paul Vanderbilt Papers," Collection 6911, unpublished finding aid, Archives of American Art, Smithsonian Institution. Accessed November 13, 2016 http://www.aaa.si.edu/collections/paul-vanderbiltpapers-6911.

${ }^{485}$ Quoted section is from A.K. Mills to Donald Clark, November 15, 1950, folder labeled "Harvard University," Box 3, Accession 506, BFRC; and A.K. Mills to Arthur Cole, October 31, 1950, folder labeled "Harvard University," Box 3, Accession 506, BFRC.
} 
Materials should be researched and evaluated by the biographer/historian first, before being given to the librarian, whose primary function "will be one of cataloging, crossreferencing and filing the material.",486

The anniversary committee decided to have Mills retain the central coordinating role, with divisions of archives, oral history, and research/writing operating alongside each other with equal authority. The oral history project was seen as a key component of the anniversary work, as it would help to fill gaps in the archival record and proactively answer some questions which might otherwise force "management or scholars to make decisions or draw conclusions based on fragmentary documentation." 487

During his visit to New York City, Mills spoke at length with Dean Anderson about the Oral History Project at Columbia University and this emerging form of historical research, pioneered just years before by Allan Nevins, the biographer under consideration for the Ford book project. Anderson outlined the process for oral history pre interviews, interviews, transcription - and suggested that the Ford Motor Company could be the first corporation to use the technique. Anderson provided detailed information concerning the necessary staff and equipment and estimated an initial expense of $\$ 40,000$. Anderson confirmed that a project could be up and running on January 1, 1951, and could complete roughly 150 interviews in the first year. ${ }^{488}$ Concerned with the need to reach key individuals while they still lived, Mills sought immediate support from Henry Ford II for the oral history program and even

\footnotetext{
${ }^{486}$ Diver actually suggested one potential research director/author, though cautioning that the person "apparently likes the bottle," "Time, Life and Fortune," October 12, 1950, Box 3, Accession 506, BFRC. See also "National Industrial Conference Board," October 10, 1950, Box 3, Accession 506, BFRC. Robert Gumbel at the Rockefeller estate offices in New York City noted the advantages of separating private and corporate papers. Staff at the National Industrial Conference Board shared examples of other anniversary publications from Firestone, Packard, the Edison Centennial, General Motors, Standard Oil, U.S. Rubber, Seiberling Rubber Company, Westinghouse, and New York Life Insurance Company. Richard Eells, a scholar, and chief of the aviation division at the Library of Congress, even promoted himself for the position of biographer and head of the archives program. "Richard Eells Papers," MS1661, unpublished finding aid, Rare Book and Manuscript Library, Columbia University Library. Accessed November 13, 2016 http://findingaids.cul.columbia.edu/ead/nnc-rb/ldpd_10301715

${ }^{487}$ Owen Bombard, "Speaking of Yesterday," December 29, 1952, Box 3, Accession 506, BFRC.

488 "Columbia University Library School," October 10, 1950, Box 3, Accession 506, BFRC; "Columbia University - History Department," November 7, 1950, Box 3, Accession 506, BFRC; and Columbia Center for Oral History website, accessed November 14, 2016 http://library.columbia.edu/locations/ccoh.html
} 
asked to use Ford's signature on a letter encouraging employees to participate. Owen Bombard, a PhD candidate at Columbia University, arrived in Dearborn and began the oral history program in January 1951. Bombard was at the forefront of the emerging use of oral history techniques. He spoke and wrote about the process throughout his career, including a detailed description of his work at Ford at a presentation at Fair Lane in December 1952 and in a 1955 article in The American Archivist. ${ }^{489}$

Having committed to Allan Nevins for the book project and Owen Bombard for the oral history project, Mills turned to formal creation of the archival program. Following his visit with Wayne Grover at the U.S. National Archives, Dr. Robert Bahmer, an assistant archivist of the United States, was invited to visit Dearborn, survey the situation in more detail, and make recommendations. It is not clear who directed this work - or who paid for Bahmer's time - but his professional stature and job title proved valuable to the archives project. Bahmer interviewed more than a dozen staff associated with records issues across the enterprise, made spot surveys of older records accumulations, and completed a thorough report in December 1950 which, perhaps not surprisingly, encouraged the project:

The important contributions of the Ford Motor Company and its founder, Mr. Henry Ford, to the social, industrial, and technical development of $20^{\text {th }}$ century civilization can be appraised correctly only if the basic historical records of the Company and of the man are preserved and made available for serious historical research. The numerous evidences of loss and destruction of significant data during the past half century point up the necessity of initiating the archives as soon as possible. ${ }^{490}$

Bahmer suggested that the project should include the historical records of the Company, any personal papers of Henry Ford, as well as those of his immediate family and other employees associated with him. "Few companies have the unique opportunity," he wrote,

\footnotetext{
489 "Notes," September 7, 1950, Box 3, Accession 506, BFRC; A.K. Mills to J.R. Davis, April 19, 1951, Box 2, Accession 506, BFRC; Adkins, "A History of the Ford Motor Company Archives," 34; Owen Bombard, "Speaking of Yesterday," December 29, 1952, Box 3, Accession 506, BFRC, 4; and Owen Bombard, "A New Measure of Things Past," The American Archivist, 18:2 (1955), 123-32.

${ }^{490}$ Bahmer, "Report on the Archives," 5.
} 
"to bring together the historical records of their operations and the records of the individuals responsible for their development."491

Bahmer encouraged the Company to see the business value of a records program, "pointing out the value of the records for legal purposes, policy formulation, and public relations and advertising support." In addition to these more internally-oriented records management goals, however, Bahmer also indicated that a business archives for Ford's inactive records should be available to both Company officials and serious scholars. The creation of such archives was a new field, he noted, and the Ford Motor Company should make a long-term commitment to the project. Rather than just an anniversary activity, the archives should become a permanent and integral part of the Company's organization. ${ }^{492}$

Bahmer outlined a plan of operations, which included recommendations for space and equipment. He provided a brief, but comprehensive overview of existing archival practices which the new archives should observe. These included creating operational policies and procedures for access to the collection by outside users, keeping accurate accession documents that recorded the provenance of all transfers, paying attention to original order of materials ("no attempt should be made to reorganize existing organized files in terms of any arbitrary overall filing scheme"), adopting appropriate boxes and shelving, as well as temperature, humidity, and security controls for storage areas. ${ }^{493}$

Working from his background at the National Archives, Bahmer encouraged modern archives techniques - and warned against the challenges of item-level description:

Library cataloguing techniques cannot be practically applied to the thousands of documents found in an archives. Some materials such as still photographs require item by item identification and control; significant

\footnotetext{
${ }^{491}$ It is not clear what arrangements were made for Bahmer's time, but Wayne Grover indicates that he "took leave" to do the work, so it is likely that Ford Motor Company provided him with some form of compensation. See Wayne Grover, Fair Lane: A Business Archives, ("An address delivered on the occasion of the dedication of the Ford Motor Company Archives at Dearborn, Michigan on May 7, 1953”) (Dearborn, Mich.: Ford Motor Company, 1953). 22 individuals are included as an appendix titled "List of Officials and Employees Interviewed" in Bahmer, "Report on the Archives," 7. See also Edmunds, "The Ford Motor Company Archives," 99.

492 Quoted section is from Adkins, "A History of the Ford Motor Company Archives," 33. The Bahmer report is also discussed in Head, "From Corporation to Museum," 3-5.

493 Quoted section is from Bahmer, "Report on the Archives," 10.
} 
items among the paper record will also be identified and listed. Initially, however, controls established should be by series and the work of description should proceed from the general to the particular. ${ }^{494}$

He further recommended that the Company hire a trained and experienced archivist to work with corporate officials on the selection and orderly transfer of records.

The report supported the program of directed oral interviews with individuals familiar with both Company and family history to help fill gaps in the documentary record. Bahmer encouraged the preservation of a broad range of records from the Company itself; while recent financial and legal records might be restricted from outside researchers, most of the material selected for the Archives should be open to serious scholars. $^{495}$

The Bahmer Report, as it became known, was distributed in January 1951 to the $50^{\text {th }}$ Anniversary Committee, other members of the executive team, and to Henry Ford II for review and consideration. Although apparently never formally approved, the document, nonetheless, provided an initial outline for development of the Archives and informed other aspects of the anniversary activity. "I think there is no doubt but that we will all be busy," Mills wrote to Bahmer in January 1951, "I only hope that it will turn out to be a monument to your foresight and planning." 496

A critical aspect of the development and operation of the Ford Motor Company Archives would be its staff. Bahmer recommended that the Archives be staffed with six employees: a chief archivist, three archives assistants, a secretary, and a clerk typist. During Mills' tours and interactions with repositories, he repeatedly requested recommendations for a person to lead Ford's archival project. "The person should be a young man," Bahmer suggested, "probably not more than 35." Bahmer felt that the chief archivist should have at least several years' experience in archives and records work.

\footnotetext{
${ }^{494}$ Bahmer, "Report on the Archives," 11.

${ }^{495} \mathrm{Head}$, "From Corporation to Museum," 5.

496 Quoted section at end of paragraph is from A.K. Mills to Robert Bahmer, January 31, 1951, Folder

"National Archives," Box 3, Accession 506, BFRC. See also Bahmer, "Report on the Archives." See also J.R. Davis to Henry Ford II, December 12, 1950, Box 2, Accession 506, BFRC.
} 
"The position will require ... someone with outstanding initiative," he wrote, "and an ability to develop the Archives into a genuine useful service activity."497

An appendix to some surviving versions of the Bahmer Report includes a list of five possible candidates for the chief archivist's position: Clifford Lord, director of the Wisconsin State Historical Society; William McCain, archivist of the State of Mississippi; Lester Capon, archivist and historian at the Rockefeller-supported Colonial Williamsburg; Robert Ballentine, an archivist with the United States Army; and Henry "Hank" Edmunds, who was ultimately selected to lead the program. ${ }^{498}$

A native of Colorado, Edmunds studied at the University of Kansas, the University of Colorado, and the library school at Columbia. He had extensive professional experience, as head archivist of the War Production Board during World War II and also as head archivist at the International Monetary Fund in Washington from its founding in 1946. He assumed the role of chief archivist at the Ford Motor Company Archives in 1951 at the age of 39 - four years beyond the age range that Bahmer had suggested - and would work with the collection until his retirement in 1977. 499

Other key archival positions were filled by individuals with library training. Not long after his arrival in Dearborn in February of 1951, Edmunds hired Richard Ruddell, another library school graduate, as his assistant archivist. Ruddell was later assisted by Klea Williamson, who had a background in records management. Notices posted at the University of Michigan library school advertised additional positions, resulting in the hiring of Winthrop Sears and Stan Graham, who both began work in Dearborn in July 1951. Sears held a bachelor's degree in library science from Columbia University and a master's in library science from the University of Michigan and remained with the Ford collection until his retirement in $1981 .^{500}$

497 Quoted section about "young man" is from "Notes," September 7, 1950, Box 3, Accession 506, BFRC; quoted section about "outstanding initiative" is from Bahmer, "Report on the Archives,"9.

498 Bahmer, "Report on the Archives," 8.

${ }^{499}$ Biographical information is from "A Historian with a Sense of Humor" (Henry Edmunds obituary), Detroit Free Press, July 25, 1982; Ford News Bureau media release, March 16, 1951, both in "Edmunds, Henry" Archives Vertical File, BFRC; Head, "From Corporation to Museum," 6; and "Historical Note" in the finding aid to Accession 506.

${ }^{500}$ J.R. Davis to Henry Ford II, December 12, 1950, Box 2, Accession 506, BFRC; “'Oral Reminiscence of Winthrop Sears," [1]; "History of the Ford Archives," typescript chronology; "Winthrop Sears (1918-

Page 248 
The Archives accepted some staff from other offices within the Ford Motor Company. Alice Benn transferred to the Archives when the Company's Public Relations Library was closed. She not only helped in describing photographs and records, but actually brought with her a large file of photographs and public relations releases. Benn had library training, so she provided an important service in maintaining the Archives' card catalog and in preparing bibliographies of books and articles about Henry Ford. Madeline Felix, daughter to one of Henry Ford's secretaries, initially worked with Owen Bombard overseeing the transcriptionists in the oral history section, but later worked in the Archives. L.J. Thompson came to the Archives following a 46-year career in the tax and real estate division of Ford's executive office. After Henry Ford's death, Thompson worked at the Fair Lane estate for eight years. "His long experience and intimate knowledge of the Company's complex operations," Edmunds noted, proved invaluable to the work of organizing some of the corporate records. ${ }^{501}$

Active professionally, Edmunds encourage staff to promote the creation of the Ford Archives to a variety of audiences:

Between now and $1953 \ldots$ the Archives staff will prepare and publish in several history journals, and in one or more industrial organs, four to six articles on 1) The Ford Motor Company Archives as a full-dress industrial archives, 2) the techniques of the Archives, including an explanation of the oral history operation, 3) the potential use of its holdings for social, industrial, business, and economic history, and 4) a company archives as a functional device in company records management. ${ }^{502}$

2000)," Open Entry (the newsletter of the Michigan Archival Association), 29:1 (Spring 2001), 11; and "Historical Note" in the finding aid to Accession 895, Winthrop Sears Records Series, BFRC, http://www.dalnet.lib.mi.us/henryford/docs/WinthropSearsRecordsSeries_Accession895.pdf accessed March 17, 2016.

${ }^{501}$ Quoted section about Thompson is from Henry Edmunds to J.W. Clarke, "Draft Letter for Mr. Moore and Mr. Dunham, RE: L.J. Thompson's retirement," April 14, 1958, Box 34, Accession 506, BFRC. See also "Oral Reminiscence of Winthrop Sears," [1-2, 5, 8]. The materials that Alice Benn brought the archives are held as Accession 536, Press Release Subseries, FMC Public Relations Series, BFRC.

502 "Role of the Archives in the Fiftieth Anniversary," Henry Edmunds to A.K. Mills, August 20, 1951, Box 2, Accession 506, BFRC. 
Within nine months of his arrival in Dearborn, Edmunds presented a paper on the new program at the annual meeting of the Society of American Archivists (SAA), resulting in an article in the April 1952 issue of the Society's journal, The American Archivist. "Under the guidance of an extremely knowledgeable and sympathetic management," Edmunds wrote, "we hope to provide an archival establishment that will be a credit to the Company and the philosophy and techniques of American archivists." 503

In connection with the 1953 anniversary year, the annual meetings of SAA, the American Association for State and Local History (AASLH), and the Historical Society of Michigan (HSM) were all held in Dearborn. Edmunds eventually became president of HSM and secretary and vice president of SAA. ${ }^{504}$

Edmunds and Ruddell explored a number of programs to assist with training graduate students in the work of business archives. Correspondence with the Department of Library Science at the University of Michigan suggested a summer course in archives and records administration. "The staff of the Ford Motor Company Archives would be completely at your disposal," he wrote, "Our staff is quite capable of presenting the practical aspects of archives and records management at the operational level." Ruddell envisioned the course being of interest to students in both library science and business disciplines, as well as practicing librarians who are "often called upon to be the ex-officio archivists of smaller businesses." Edmunds and Ruddell also pursued funding from the Ford Motor Company Fund for a fellowship program in which students would work 400 hours during a ten-week summer semester. The proposal emphasized the responsibility of the Ford Archives - now generally recognized as a leader in the business archives field to help train new archivists for similar work with other corporations. Although there is no evidence either of these programs was implemented, the ideas reflect an interest in the Archives to advance academic standards in the profession. ${ }^{505}$

\footnotetext{
503 Edmunds, "The Ford Motor Company Archives," 99-104.

${ }^{504}$ See "Scope and Content Note" in the finding aid to Accession 506, BFRC, http://www.dalnet.lib.mi.us/henryford/docs/MillsEdmundsAndNevinsAndHillSeries_Accession506.pdf accessed March 17, 2016. See also the "History of SAA Leadership," http://www2.archivists.org/history/leaders, accessed November 19, 2015.

${ }^{505}$ Quoted section is from Richard Ruddell to Henry Edmunds, "University of Michigan Course in Records," November 22, 1955, and Richard Ruddell to Raymond Kilgour, November 28, 1955, both in
} 
The Ford Motor Company Archives inhabited a number of physical spaces between 1950 and 1964. Staff took up initial residence in makeshift facilities in former farm offices and the broadcasting studio in the Ford Motor Company Engineering Laboratory building in Dearborn. "Our quarters are utilitarian," Edmunds noted in April 1952, “our equipment plain, and our procedures simple." The facility was located across a pond from the main building of the Henry Ford Museum. The staff ate at the Engineering cafeteria with the engineers and had access to the office that Henry Ford used in the building until the time of his death just four years previous. ${ }^{506}$

Patricia Diver, the marketing manager Mills met with at Time/Life in New York, proved prescient of potential problems between researchers and librarians, as the Ford Archives project and the Nevins and Hill book project encountered some initial growing pains. Nevins insisted on hiring his own research assistants and that his group would draw together the records they felt were necessary for the book from the various Ford offices and records caches. Mills and Edmunds felt that this was actually their charge, and that they would be doing the work of gathering and organizing records, with the Nevins group retaining only a research role. At a meeting in August 1951, Nevins visited the fledging Archives and acknowledged the large amount of work which had been completed. He agreed to work collaboratively with the archivists - and was encouraged enough to revise his schedule and complete the first volume for publication before the

folder labeled "University of Michigan," Box 33, Accession 506, BFRC. See also draft memoranda to William Pine, July 1954, and Richard Ruddell to Henry Edmunds, "Ford Motor Company Fund for Working Fellowships," March 6, 1956. Both in Accession 506, Box 29, folder labeled "Fellowships," BFRC.

${ }^{506}$ Quoted section is from Edmunds, "The Ford Motor Company Archives," 99-100. See also "Oral Reminiscence of Winthrop Sears," [2]; Head, "From Corporation to Museum," 4, 10; J.R. Davis to Henry Ford II, December 12, 1950, Box 2, Accession 506, BFRC; and "History of the Ford Archives," typescript chronology. The Ford Motor Company considered placing the records at the Detroit Historical Museum, whose new facility on Woodward Avenue in Detroit was under construction at the time. Carl White of the Columbia University Library School "agreed with Mr. Ford that the Detroit Museum would probably not be the best place for the archives," while scholar Richard Eells was concerned that a "civil and municipal enterprise might not recognize the importance of the material." See "Columbia University Library School," October 10, 1950, and "Richard Eells," October 12, 1950, Box 3, Accession 506, BFRC and "Minutes of Meeting of Committee on $50^{\text {th }}$ Anniversary of Company Held in the Office of Mr. J.R. Davis May 2, 1950," Box 52, Accession 506, BFRC. 
end of the anniversary year in 1953 (though Nevins' publisher, Charles Scribner's Sons, would delay the publication until February 1954). ${ }^{507}$

A permanent location was needed to house the staff and collections of the growing historical program. Ironically, the death of Henry Ford's wife, Clara, on September 30, 1950, provided several unexpected benefits to the archives project. Of greatest importance was the records discovered in the Fair Lane mansion. During one of Robert Bahmer's visits to Dearborn, a "search party" was organized to survey and assess the documents stuffed in desk drawers and cupboards, as well as dozens of boxes in the Fair Lane basement. Most of the records were personal papers of Henry Ford, though some were from the Company, presumably brought back with him from the office. After consultation with members of the Ford family, the Fair Lane Papers (74 cubic feet, 18351950, Accession 1), as they came to be known, were to be included in the Ford Archives. Archives' staff were sensitive to ensuring the Ford family that "any material of a special personal or controversial nature" would be referred to Henry Ford II for review (such materials could be "restricted or sealed for the present if you feel it desirable"). 508

Clara Ford's death raised questions about what should be done with the Fair Lane mansion and grounds. In the spring of 1951, the Ford Motor Company purchased the property from the family, to develop into a memorial for Henry and Clara Ford. In addition to the mansion itself, the property covered more than 1,300 acres and included four cottages, a summer bungalow, ten out-buildings, and Henry Ford's combined powerhouse, garage, and experimental laboratory and formal gardens planned by Mrs. Ford. ${ }^{509}$

Just as one of the Hagley's precursors was housed in a former du Pont family mansion, the Ford Archives ended up being housed in a former Ford family mansion. In August 1951, the Company announced its intention to make Fair Lane the permanent

\footnotetext{
507 Adkins, “A History of the Ford Motor Company Archives,” 36, 39-40.

${ }^{508}$ Quoted section about "controversial nature" is from J.R. Davis to Henry Ford II, December 12, 1950, Box 2, Accession 506, BFRC. See also Edmunds, "The Ford Motor Company Archives," 101; Head, "From Corporation to Museum," 6; and Adkins, "A History of the Ford Motor Company Archives," 45. Sidney Olson gives a colorful description of the search in his introduction to Young Henry Ford, ii.

${ }^{509}$ Head, "From Corporation to Museum," 10. "History of the Ford Archives," typescript chronology.
} 
home for the historical records. The Ford Archives at Fair Lane, as it became known, was intended to become a "semi-public institution," one report indicated. "The Archives will be made available as a research center for historians, serious writers, and artists who are developing historical materials on Ford subjects."

Over thirteen months, Fair Lane was converted from a residential building into a fully functioning archival repository. Contractors installed a freight elevator and separate book lift to ease the movement of materials between floors. They filled an indoor swimming pool with concrete to create a two-tiered stacks area for records storage. They created additional storage in a former bowling alley and basement storage rooms. In all, the conversion created more than 10,000 cubic feet of manuscript and print items. It was deemed too expensive to install air conditioning throughout the structure, so only the stacks areas were included in the new cooling system, and a year later a fire suppression system was also installed. Lighting and electrical services were perhaps the most challenging to implement while remaining sensitive to the historic structure. ${ }^{511}$

During the renovations, staff continued organizing papers initially gathered from the Company and from Fair Lane. They paid attention to provenance, with separate record sets assigned unique accession numbers identifying their sources (and differentiating them from other units). Edmunds and Ruddell created an overarching structure for the accessions, dividing them intellectually into three major headings - Ford Motor Company, subsidiary companies controlled or owned by Ford, and personal records of the Ford family (including personal records of other Ford employees). The structure provided a logical arrangement not only for descriptive practice, but also for physical shelving so that like materials could be housed adjacent to one another. ${ }^{512}$

As staff identified new materials for transfer to the Archives, they assigned accession numbers and made short written preliminary evaluations. They stamped or

\footnotetext{
${ }^{510}$ Quoted section is from "A General Outline of Plans and Activities Prepared by the Executive Secretary, $50^{\text {th }}$ Anniversary Committee," ca. May 1952, Box 2, Accession 506, BFRC. See also "Fair Lane Fact Sheet," May 7, 1953, folder labeled "Fair Lane Fact Sheets, 1953," Box 1, Accession 895, BFRC; Head, "From Corporation to Museum," 10; and "History of the Ford Archives," typescript chronology.

${ }^{511}$ Head, "From Corporation to Museum," 10-12.

512 Richard Ruddell to Henry Edmunds, "Proposed Changes to Records Control," July 8, 1952, Box 33, Accession 506, BFRC.
} 
affixed accession numbers on box labels before transit. Although it is possible that Edmunds' staff expected to complete further arrangement and description at some later date, their minimal level of work would haunt decades of subsequent archival workers. As was the case at Baker, Hagley, and Smithsonian, Ford Archives staff at this formative stage proved good at collecting material, but, also like their peers, they failed to remove duplicates, eliminate useless documents, or complete more than rudimentary description. ${ }^{513}$

Archives' staff created a card catalog with a subject cross index to track accessions, and the record group numbers they assigned as individual accessions were inventoried and described. Staff also developed an additional card subject index for references noted in printed books - what Edmunds called the Index to Source Materials along with procedures for ongoing additions. These indexes and card catalogs became as valuable to the Archives as some of its official records. ${ }^{514}$

Archivist Winthrop Sears recalled working with the extensive photographic collections. The needs of several key projects connected to the $50^{\text {th }}$ anniversary made processing photographs a priority. The Nevins and Hill book project, for instance, included a series of plates featuring photographs from the collection. In addition, advertising executive Sidney Olson needed a large number of photographs to support The American Road project. Olson intended to publish a photographic biography of Ford separately. Although that publication wouldn't appear for several decades, Winthrop Sears noted that the images Olson gathered were ultimately kept together as a core collection at the Ford Archives:

Because of Olson's need, the processing of photos was given priority. They were in cartons, totally disarranged. Dick [Ruddell] and I and other staff members sorted them into broad categories, such as Plants, Automobiles, Residences, Employees, etc., which we later subdivided. Sid [Olson] helped us identify many pictures, as he was working with pictures intensively ... The oral historians also helped by showing old photos to persons being interviewed, particularly group photos of employees and early plant scenes. Interviewees sometimes donated photos. ${ }^{515}$

\footnotetext{
513 Ibid.

${ }^{514}$ Edmunds, "The Ford Motor Company Archives," 102-103.

515 “Oral Reminiscence of Winthrop Sears," [4].
} 
Sears had primary charge of the photography collections, maintaining prints and negatives, and managing the emerging nomenclature for the subject headings. In most cases, requests for copies required that selected photographs and documents themselves be photographed, with new prints made from the copy negatives. ${ }^{516}$

Staff, offices, and records moved into Fair Lane in September 1952, combining the corporate records, the personal papers of the Ford family, and the oral history program under one roof for the first time. Some of the material was still stored in its original containers, including 171 file cabinets from the Henry Ford Office in the Engineering Laboratory building. Although most material went immediately into the mansion, some materials of secondary importance were placed temporarily in the outlying cottages. ${ }^{517}$

The formal dedication ceremony took place at Fair Lane on May 7, 1953, just a month before the actual $50^{\text {th }}$ anniversary of the Ford Motor Company. "In many respects," one report stated, "the Ford Archives was the nucleus of the $50^{\text {th }}$ anniversary program," and its dedication launched the public phase of the commemorative programs. Hosted by Henry Ford II, the ceremonies were brief and informal, featuring a ribboncutting by his mother Eleanor Ford (widow of Edsel Ford) and the dedication of a commemorative plaque. A.K. Mills was introduced as the permanent director of the Ford Motor Company Archives (while also continuing as executive director of the Edison Institute). ${ }^{518}$

\section{A booklet entitled Fair Lane: Ford Motor Company Archives provided an} overview of the archival program. The illustrated 24-page booklet gave a history of Fair Lane from its construction as home to Henry and Clara Ford, through its conversion for use by the Ford Archives. Photographs depicted interior rooms, including public spaces such as the reference room, library, and exhibit spaces, as well as staff offices, the processing room, and the stacks area. The volume also reproduced documents from the

\footnotetext{
516 Olson, Young Henry Ford, iii; and "Oral Reminiscence of Winthrop Sears," [3-6].

${ }^{517}$ Head, "From Corporation to Museum," 13; "History of the Ford Archives," typescript chronology; "Oral Reminiscence of Winthrop Sears," [3]; and The Ford Archives, 8.

${ }^{518} \mathrm{Head}$, "From Corporation to Museum," 13; and "Historical Note" in the finding aid to Accession 506.
} 
Archives' collections. Two additional publications were released at the dedication: Rules Governing Use of Ford Motor Company Archives, which had been in draft form for more than a year, and an illustrated guide to the Fair Lane house and gardens. ${ }^{519}$

A reception followed the dedication ceremony and featured an address by Dr. Wayne Grover, Archivist of the United States. He lauded the Ford Motor Company for creating a new model for business archives, one which would encourage more companies to preserve and provide access to their records. Grover likened the Ford Archives to the United States National Archives - requiring certain materials to remain restricted for a short-term, but bound by a greater public good to encourage transparency and learning. Grover indicated that the Ford Archives could become the national center for research on the automobile industry and on mass production in general. "It is probably correct to say that the Ford Motor Company Archives won't sell many Ford cars," he told the audience, "but it will support the Company's business affairs, provide a lasting memorial to Henry Ford, and also serve as a ground-breaking exercise in responsibility to the public." 520

Two exhibits, one at Fair Lane and another at the Museum, highlighted the primary documents discovered during the project. At the mansion, the exhibit told the story of Henry and Clara Ford, their childhoods, their courtship (revealed through early correspondence), the construction of Fair Lane, and their life there together. Ford Archives staff partnered with Museum staff for the second, more artifact-oriented exhibit, which explored Henry Ford's mechanical and business life. Located in a newly remodeled "Ford Room" at the Museum, the exhibit included Henry Ford's first automobile, his Highland Park office, and camping equipment he used with Thomas Edison and Harvey Firestone. The Museum's descriptive material credited Archives staff. $^{521}$

${ }^{519}$ Fair Lane: Ford Motor Company Archives (Bulletin No. 1) (Dearborn, Mich.: Ford Motor Company, 1953); Rules Governing Use of Ford Motor Company Archives (Bulletin No. 2) (Dearborn, Mich.: Ford Motor Company, 1953); and Fair Lane: The House and Gardens (Bulletin No. 3) (Dearborn, Mich.: Ford Motor Company, 1953).

${ }^{520}$ Grover, Fair Lane: A Business Archives.

521 "Oral Reminiscence of Winthrop Sears," [3]; "Opening of Ford Archives," ca. July 1953, Folder 1, Box 1, Accession 895, BFRC; Jeanine Head, "From Corporation to Museum," 29. 
The Archives saw immediate use for a variety of research projects. Primary support was given to Company officials "in whatever degree their work may demand." Edmunds claimed that representatives from every department within the Company used records in the Archives. "[T]hose departments that have deposited to our care the greatest body of records," staff noted, "are the very departments that have the most frequent occasion to call upon us and those records." These included staff in Finance, Industrial Relations, Office of the Counsel General, Sales and Advertising, Public Relations, the Engineering Office, and the Executive Offices. ${ }^{522}$

Another critical group of archival researchers were Allan Nevins, Frank Hill, and their group of full-time researchers for the book project. The group was provided special support and maintained a set of file cabinets to which they could charge out original documents. Contrary to Robert Bahmer's instruction never to "reorganize existing organized files in terms of any arbitrary filing scheme," staff of the Ford Archives found value in the new Nevins-Hill arrangement system and, although cross-references were kept, the relocated research files were retained as a grouping called Nevins and Hill Research (14.4 cubic feet, 1845-1960, Accession 572). ${ }^{523}$

While not broadly open to the public, the new corporate archives granted access to external researchers. Projects were expected to show "a serious and important purpose which can be satisfied only through the study of primary materials." Similar to Baker Library and Hagley, researchers were required to apply for access in advance of a visit, describing the scope of their intended work and proof qualifications - either by academic background or "comparable special competence." Staff issued admission cards to authorized users and provided detailed instruction on the use, care, and handling of documents. The Edmunds-authored guidelines also required researchers to have all materials reviewed by a staff member to "discharge their responsibilities as custodians of

\footnotetext{
${ }^{522}$ First quoted section is from "Rules Governing Use of Ford Motor Company Archives: Preliminary Draft," February 1953, Box 33, Accession 506, BFRC. Quoted section about "greatest body of records" is from "Business Archives Service to Industry as Exemplified by Ford Motor Company Archives," (no author, but likely Henry Edmunds), June 9, 1955, Box 33, Accession 506, 4. BFRC.

${ }^{523}$ Quoted section is from Bahmer, "Report on the Archives,"10; see also "Oral Reminiscence of Winthrop Sears," [6].
} 
vast amounts of documentary information touching on current events or living persons." 524

The Archives also responded to questions received through the mail from buffs, collectors, and the general public. By June of 1955, staff in the Reference Section were answering more than 100 questions per month, with nearly half coming from outside the Company, everything from casual questions from the general public about the history of Ford Motor Company or its products to questions requiring extensive research by Archives staff. ${ }^{525}$

By September 1951, the Ford Archives at Fair Lane was a recognized part of the Ford Motor Company records program alongside the Controller's Office in Finance, the Office Services Department of Finance, and the Archives Department of the $50^{\text {th }}$ Anniversary Plans Office. Under this records program, the Highland Park records depository was used for non-permanent materials awaiting destruction once their legal or fiscal value was assessed. Vital records were securely stored in vaults at each location, and the Ford Motor Company Archives at Fair Lane was the acknowledged location for the permanent and historical records of the Company. The system was intended to "reduce as rapidly as possible ... the quantity of the Company's business records to the minimum essential for administrative, financial, operational, legal or research purposes." 526

Yet, this arrangement failed to delegate clear responsibility to a single individual or unit. Recommendations by senior finance executives in the Company in 1951 and 1952 to centralize all records functions under Mills' office were not implemented, perhaps to limit the items made available to Nevins and other external researchers. The 1952 proposal, for instance, included a list of categories which might contain sensitive information about living individuals that needed to be restricted from public access. The Ford Archives remained separate, and a new records program maintained the independent

\footnotetext{
524 "Rules Governing Use of Ford Motor Company Archives: Preliminary Draft," February 1953, Box 33, Accession 506, BFRC.

525 "Business Archives Service to Industry," 6.

${ }^{526}$ C.E. Bosworth to V.Z. Brink and A.R. Miller, "Organization of Records Administration Activities," September 28, 1951, Box 33, Accession 506, BFRC, 1.
}

Page 258 
authority of the Archives "for the selection and maintenance of records which have historical significance or are of public interest." A ten-year cutoff margin was established between current operating files and those records transferred and made accessible in the Archives. ${ }^{527}$

By the end of the 1953 anniversary year or by early 1954, Mills had succeeded in creating the "central library of information for writers and historians for years to come" envisioned in 1950. The Archives contained more than five million documents, both personal and Company papers, and 25,000 photographs. Although never intended to be a full representation of all records, in just four years, the Archives had gathered a surprisingly large amount of historical materials. ${ }^{528}$

As Nevins, Edmunds, and their staff had expected, it wasn't easy to separate the personal papers of Ford family members from Henry Ford's office files, or from the other records of the Company. Archivists remained attentive, however, to the provenance of record groups, with individual accession numbers providing separation by source and/or location. Inventories and other lists of accessions allow for some analysis of the core materials collected during the period 1950-1954. These include summaries created by Edmunds' staff and other internal administrative reports, as well as dozens of articles and guides published subsequently. Comparison of a key external 1964 appraisal of the collections (described later below) with a 2017 overview of Ford Motor Company Record Groups used at the Benson Ford Research Center at The Henry Ford proves that most of the structure created by Edmunds' staff during their original accessioning remains in use today. ${ }^{529}$

${ }^{527}$ Quoted section is from T.O. Yntema executive memo, May 2, 1952, "Records Management Program," Box 33, Accession 506, BFRC. See also Bosworth to Brink and Miller, "Organization of Records Administration Activities;" H.R. Leonard to A.R. Miller and A.K. Mills, "Organization of Records Administration Activities," March 26, 1952, Box 33, Accession 506, BFRC; and "Business Archives Service to Industry," 6-7.

528 "Opening of Ford Archives," ca. July 1953, Accession 895, BFRC.

${ }^{529}$ There have been more than a dozen inventories and summaries of the manuscript collections created since the 1950s. Some more of the more useful examples are an undated "Accession Summary" [likely January 1952], folder labelled "Reduction in Archival Holdings," Box 33, Accession 506, BFRC; Edmunds, "The Ford Motor Company Archives;" Head, "From Corporation to Museum;" Wrixom to Farris, "Archives Study Progress Report;" Bakken, "The Ford Archives: The Next Quarter of a Century;" 
Most of the personal papers of the Ford Family were gathered in several core collections. The Fair Lane Papers (74 cubic feet, 1835-1950, Accession 1) comprised the personal papers pulled from the mansion at the time of Clara Ford's death. Accompanied by another ten accessions relating to the Fair Lane Estate and other properties, the collection documents the varying interests of Henry and Clara Ford outside of Henry's primary automotive business interests. Historian Jeanine Head noted an amazing amount of correspondence from prominent individuals and lesser knowns. "Hundreds of greeting cards, magazines and household bills," she wrote, "provided an intimate look into the everyday lives of the Fords and a broader view of American life and society during the years 1863-1950." 530

The main body of Ford Motor Company records contained material from the Secretary's office, legal and financial divisions, engineering, manufacturing and automotive units, industrial relations, and sociological departments, as well as purchasing, sales, and public relations. Company records in the Benson Ford Research Center today include hundreds of discrete accessions with a combined extent of 2,275 cubic feet. When Bahmer reviewed the Archives in 1950 he was surprised at how little executive correspondence had been retained by the Company, particularly from the earliest periods of its history. This encouraged Bombard's oral history program to gather "information about the early history of the Company by interviews with living participants." But it also required that anything dating before World War II be carefully reviewed and likely preserved. ${ }^{531}$

In between the Fair Lane personal papers and the official records of the Ford Motor Company was another large collection of material known as the Henry Ford Office. Staffed as early as 1911 with his own personal staff, the unit became a standalone operation after Ford's resignation as president of the Company in 1919. The Henry Ford Office records cover four primary groupings: the Highland Park Office records subgroup

and Terry Hoover, "Henry Ford Museum \& Greenfield Village Archives, Manuscripts, Library Holdings, and Special Collections," Michigan Historical Review, 27:1 (Spring 2001), 154.

${ }^{530} \mathrm{Head}$, "From Corporation to Museum," 7.

${ }^{531}$ Bahmer, "Report on the Archives,"4-5. 
(62.4 cubic feet, 1902-1928, Accessions 2 and 62), the Engineering Laboratory Office Records subgroup (1,248.8 cubic feet, 1920-1952, Accessions 284 and 285), a Financial Records subgroup (254.5 cubic feet, 1912-1952, Accessions 286, 790, and 254), and the Personal Topics Subject Group (54.3 cubic feet, 1823-1948, Accessions 23, 292, 62, 413, 288, and 289).

Totaling more than 1,620 cubic feet, the Henry Ford Office Records include detailed business records for Henry Ford's business activity outside of the Ford Motor Company, such as the Detroit, Toledo, and Ironton Railroad, the Dearborn Publishing Company (which Ford controlled to publish the Dearborn Independent), the Henry Ford Hospital, the Dearborn State Bank, and the tractor company he began with his son, Edsel, named Henry Ford and Son. The collections also include materials from Ford's Peace Ship expedition of 1915 and his aborted plans to develop Muscle Shoals, Alabama, into an industrial hub to rival Detroit.

Ford Motor Company photographic materials were organized under several accessions, the most important being the General Photographic Series (178 linear feet, 1913-1954, Accession 833), two groupings collected by the Engineering Department (the Photographs for the Company series, 100 cubic feet, 1918-1954, Accession 189, and the Photographs for Henry Ford series, 1918-1950, 87.6 cubic feet, Accession 188), and what would later be accessioned as the Photographic Vertical File (53.3 linear feet, 1860-1980, Accession 1660) but was created by the Ford Motor Company Archives staff during the early 1950s.

The voracious collecting of Edmunds' staff in the early 1950s also secured other important sets of records, such as the office records of key Ford employee Charles Sorensen (69.6 cubic feet,1913-1946, Accession 38) and Ford Engineer William Mayo's oversight of the Stout Metal Airplane Division (73.6 cubic feet, 1920-1932, Accessions 18, 251, and 383).

The Archives gathered collections of books, periodicals, and Ford Motor Company publications, as well as sales literature, product manuals, and other printed items. Edmunds' staff located more than 200 bound volumes of Detroit newspapers and acquired 200 albums of newspaper clippings (65 linear feet, 1911-1951, Accession 7) 
which were indexed and covered major news stories pertaining to Henry Ford or the Company from 1913 to 1947. A large collection of motion picture materials - some of which were deteriorating rapidly -- also made their way into the emerging Archives collection. $^{532}$

Owen Bombard's oral history program was a critical component of the documentation effort. Edmunds reported in The American Archivist that while the oral history project might appear "somewhat beyond the traditional archival concept" of care and oversight of records, it was actually "engaged in manufacturing archives." The program interviewed key individuals who had worked with Henry Ford in order to fill in factual information not covered in the records themselves. Mills realized that many documents had not survived. Additionally, the use of informal meetings and the telephone in modern business practices meant that some major policies and decisions were made without "a shred of written evidence." Over the course of the project, Bombard and his staff conducted more than 300 interviews, including friends, associates, servants, and employees of Henry Ford. These formed The Owen W. Bombard Interview Series (45.2 cubic feet, 1951-1961, Accession 65). Finished transcripts were individually bound and included an index, table of contents, and photograph of the subject. ${ }^{533}$

As was the case at Baker Library, Hagley, and Smithsonian, archivists at Ford tested the boundaries of the topical collection scope. Several sources suggest that Mills and Edmunds believed the collections could - and should - expand beyond the lives of Henry Ford and the development of the Ford Motor Company. "[S]ince we here at the

\footnotetext{
${ }^{532}$ Bahmer recommended retaining books that may have had a role in influencing Henry Ford's actions. As the project progressed, Nevins, Bombard, and others suggested additional book titles to help inform their research. A collection of bound newspapers was stored on shelving in the former bowling alley. Edmunds and Ruddell culled the book collection in 1952 to a core grouping of under 8,000 titles. High use items were kept in display cabinets in the reading room, while the remainder were kept in a nearby library space or in a secondary stacks area. 1,700 titles deemed worthless to the collections were disposed. See Bahmer, "Report on the Archives," 4. See also "Oral Reminiscence of Winthrop Sears," [2,3]; Richard Ruddell to Henry Edmunds, "Proposed Changes to Records Control," July 8, 1952, Box 33, Accession 506, BFRC; and Fair Lane: Ford Motor Company Archives (Bulletin No. 1) [15-16].

${ }^{533}$ Quoted section about "manufacturing archives" is from Edmunds, "The Ford Motor Company Archives," 103. Quoted section about "written evidence" is from an unpublished budget presentation document, 1956, Box 9, Accession 506, BFRC, and is also found in Head, "From Corporation to Museum," 8. See also "Oral Reminiscence of Winthrop Sears," [3]; and Head, "From Corporation to Museum," 10.
} 
Archives are interested in preserving the history of the Ford Motor Company," one argued, "we cannot ignore the automobile industry as a whole." In November 1952, Archives assistant Richard Ruddell outlined a plan to expand the collection to other materials, possibly partnering with the Museum Library:

A working agreement should be reached with the various libraries in the Ford Motor Company and, more particularly, the library of the Henry Ford Museum to secure in this one location all the local holdings in the field of automotive history. Compensatory materials might be exchanged for the material that we would receive. For example, the Henry Ford Museum Library might well be expected to concentrate on Henry Ford's non-Ford Motor Company interests which we could augment considerably from our own library. Conversely, the Archives should be expected to have those materials relating to Henry Ford's interest in the automotive field. ${ }^{534}$

Ruddell suggested that the Archives book budget be used to purchase a variety of automotive-related collections, both in the United States and abroad. "I feel confident that within six months," he wrote, "we could legitimately claim to be the number one repository of historical materials in the industry." 535

Historian Jeanine Head noted the new Ford Archives quickly acquired early automotive sales literature from competitors, as well as early general automotive periodicals. And, in 1954, the Archives accepted the transfer of 30,000 photographs relating to the Autocar Company (107 cubic feet, 1897-1932, Accession 424), one of the earliest automobile manufacturers in the United States, founded in 1897. Mills described the collection as the "largest single gift ever made to the Ford Archives from an outside source," and Ruddell described the acquisition as "one of the most important moves in the field of automotive history since the Ford Archives was founded." The collection had

${ }^{534}$ Richard Ruddell to H.E. Edmunds, “Automotive History Collection,” November 12, 1952, Box 33, Accession 506, BFRC.

535 Quoted section about "preserving the history" is from Head, "From Corporation to Museum," 18. The quote is attributed to a memo written by Richard Ruddell which is not repeated in the only other memo the author found on this topic. Unfortunately, Head's footnote provides an incorrect location for the source; the document does not reside in Box 44 of Accession 506 at the Benson Ford Research Center. The author has been unable to locate the original. Quoted section about "number one repository" is from Richard Ruddell to H.E. Edmunds, "Automotive History Collection." 
been held by the Franklin Institute in Philadelphia for several decades, and staff at the two institutions decided that the materials would be better served in Dearborn. Yet beyond these few examples, little evidence exists of expansion into non-Ford manuscript collections. Certainly none of the inventories, guides, and publications of the Ford Motor Company Archives record any significant amount of manuscript material collected outside of the central Ford story. ${ }^{536}$

Some materials uncovered during the archival start-up were not retained in the permanent - and publicly accessible - archival collections. Three-dimensional historical artifacts were often sent to the Public Relations department for incorporation into the exhibits at the Rotunda, while select pieces were sent to the Edison Institute Museum for preservation and inclusion in its exhibits. Edmunds and Mills remained sensitive to the privacy of the Ford family and protective of the Ford brand. They knew many influential Ford executives were not enthusiastic about the Archives project, and we may assume that recommendations to re-orient the Ford Archives under a finance or public relations executive reflected a desire to control access. Some materials were returned to the Ford family - either upon their request or at the suggestion of Archives staff. From the project's inception, staff were careful to refer controversial material to Henry Ford II for review. In 1951, for instance, a large collection of documents from the Edsel Ford collection (measuring 106 linear feet) was returned to Henry Ford II. A November 1952 memo from Mills to Henry Ford II referenced another removal:

Immediately after your visit to the Archives, Mr. Edmunds and his staff set about removing from the general collections of the Archives all of the invoices belonging to your father and grandfather. These are now being placed in a special room on the lower floor under lock and key. Mr. Edmunds has assured me that these records will not appear on any lists or indexes which the Archives might prepare, indicating their availability or their existence. ${ }^{537}$

\footnotetext{
${ }^{536}$ Quoted sections are from Richard Ruddell to Louis Clarke, July 2, 1954, and “Autocar Historical Collection Given to Ford Archives in Dearborn, Michigan,” Virginia Highway Users Magazine, 22:(September 1954), 22, both in folder labeled “Autocar Collection," Box 29, Accession 506, BFRC. Jeanine Head also references the Autocar collection in "From Corporation to Museum," 18.

537 A.K. Mills to Henry Ford II, November 4, 1952, folder labeled “Correspondence, Jul-Dec 1952,” Box 7, Accession 506, BFRC.
} 
These interactions likely encouraged Mills, Edmunds, and other staff to become cautious gatekeepers and protectors of the Ford legacy. ${ }^{538}$

By the end of the Ford Motor Company's $50^{\text {th }}$ anniversary celebrations, the great period of growth was complete, and the Ford Archives had become "one of the great storehouses of facts on this continent." The program had become a model for other companies, and Edmunds reported that requests for tours of the Archives were regularly received from visiting archivists, historians, and other interested groups. ${ }^{539}$

The various $50^{\text {th }}$ anniversary activities succeeded in elevating the profile of both Henry Ford and the Company, and the creation of the Archives was recognized as perhaps the greatest accomplishment of all:

The new image of Ford is the achievement of the Archives and the chronicles who are using its resources. What the Archives has done - and continues to do - is to organize in an objective and dispassionate way the history of the Ford Motor Company as it exists in documentary papers and pictures, and then make its files available, concealing nothing. What the journalists and historians seem to be doing, after using the vast resources of the Archives, is to show that the balance of Henry Ford's accomplishments were great and many, and contributed far more to the common good than Americans have a right to take for granted. ${ }^{540}$

The publication of Nevins and Hill's first volume in 1954 further proved the value of the Ford Motor Company Archives. Although not without its critics, their book supported the premise that allowing a "complete revelation of company records" to scholars proved

\footnotetext{
${ }^{538}$ Cynthia Read Miller referenced the removal and burning of papers relating to Edsel Ford in a personal interview with the author in 2016: "I could never figure out what they took away, and what they left behind" (personal interview, August 12, 2016). Judith Endelman reported that the empty shelves are still retained at the Benson Ford Research Center (personal interview, July 25, 2016). See also "Accession Summary," undated [likely January 1952], folder labelled "Reduction in Archival Holdings," Box 33, Accession 506, BFRC; Bosworth to Brink and Miller, "Organization of Records Administration Activities;" J.R. Davis to Henry Ford II, December 12, 1950; and A.K. Mills to Henry Ford II, November 4, 1952.

${ }^{539}$ Quoted section is from Olson, Young Henry Ford, xi. See also Adkins, "A History of the Ford Motor Company Archives," 39; and "Requests For Visits," undated, Box 2, Accession 506, BFRC.

540 “A Report on Ford's 50 $0^{\text {th }}$ Anniversary," ca. 1954, Box 1, Accession 365, Ford Motor Company Fiftieth Anniversary Report, BFRC. Quoted section is from Adkins, "A History of the Ford Motor Company Archives," 40.
} 
"less damaging to the prestige of an industry than a concealment of this data." Henrietta Larson, editor of the Bulletin of the Business Historical Society, and participant in the business archives program at Baker Library, acknowledged the milestone achieved in Dearborn. "[T]his is the first time a large American corporation has established a separate organization not only to preserve and handle its historical records, but also to make them available to scholars for research." 541

Mills and Edmunds had succeeded in gathering, preserving, and providing access to the records of the Ford Motor Company and the Ford family. Their 1955 Guide to Selected Records of the Ford Motor Company reported 5,373 feet of Company records, 1,197 feet of personal papers, and more than 175,000 photographs. Advertising executive Sidney Olson estimated that 20 percent were records of the Ford family, 70 percent were records of the Ford Motor Company, with the remaining 10 percent related to other companies and people. Olson doubted that a "whole tribe of historians" could exhaust the "pleasures its information can bring to people who like to read about America." 542

\section{Disinterest, Disinvestment, and Disposal of the Ford Motor Company Archives, 1954-1964}

Just as an anniversary had created the need for a Company Archives, the completion of the various $50^{\text {th }}$ projects - public events, documentary films, and the first volume of the scholarly history - reduced the Archives' ongoing utility to the Company. This situation was compounded by A. K. Mills' fatal heart attack on September 12, 1954. The loss of this leader - a former personal friend of Henry Ford who had a direct line of communication with Henry Ford II - provides a critical juncture in the history of both the Archives and the Edison Institute. Eight days after Mills' death, the company shifted the

\footnotetext{
${ }^{541}$ Quoted section about "concealment" is from Reynolds Wik, review of Ford: The Times, the Man, The Company in The Mississippi Valley Historical Review (September 1954) quoted in Head, "From Corporation to Museum," 16. Quoted section about "first time" is from Henrietta Larson, "Ford Motor Company Archives," Bulletin of the Business Historical Society, 27:2 (June 1953), 124.

${ }^{542}$ Head considered the period 1950-1955 as the "first great period of growth" for the Ford Archives, Head, "From Corporation to Museum," note 9. The 1955 "Guide" is located in folder labeled "Archives," Box 1, Accession 895, BFRC. See also Olson, Young Henry Ford, 4.
} 
reporting line of the Archives from the President's Office to the head of Public Relations. ${ }^{543}$

The mid-1950s provided economic challenges to the automotive industry. A dip in sales for Ford Motor Company in the 1956 fiscal year prompted reviews of all aspects of the firm's operations. Possibly affirming Wayne Grover's comment that "the Ford Motor Company Archives won't sell many Ford cars," this review included the costs associated with its fledgling archives. Like other corporate archives, the Ford Archives "began to experience the 'down side' of the financial cycles that characterize the history of American corporate archives.” Ford Archivist Elizabeth Adkins later questioned whether Edmunds' plan to expand the collection's scope might have been a tactical error, developing fears in administrators' minds of expanding costs and unintentionally hurting the long-term viability of the program. ${ }^{544}$

In 1956, T.L. Bewick, an executive on the Ford Public Relations staff, proposed reducing the rising operational costs of the Fair Lane property. One alternative he suggested would have spent $\$ 8,500$ to dig up most of the flower gardens and replace them with grasses for ease of maintenance, while another recommended closing the building to public access to reduce maintenance and security expenses. Other suggestions included closing the oral history program and slowing new records transfers to the Archives. One of his alternatives would have retained the Archives at Fair Lane, but another option moved the Archives and disposed of the Fair Lane property to the City of Dearborn or simply boarded it up. ${ }^{545}$

Henry Edmunds, hoping to preserve Fair Lane "as it was originally intended," suggested charging admissions and use fees to offset the high cost of maintaining Clara Ford's extensive gardens. But in the end, the Company decided to divest itself entirely of the Fair Lane property. On December 17, 1956, the Company announced a gift of land

\footnotetext{
543 "History of the Ford Archives," typescript chronology; Head, "From Corporation to Museum," 19; "Historical Note" in the finding aid to Accession 506.

${ }^{544}$ Quoted section is from Grover, Fair Lane: A Business Archives; See also Adkins, "A History of the Ford Motor Company Archives," 27-28, 41.

545 T.L. Bewick to S.W. Morrell and Henry Edmunds, "Proposal for Physical Changes to Archives Department," April 24, 1956, folder labeled "Plan for Operations 1957," Box 1, Accession 895, BFRC.
} 
and capital development money to support the development of the new University of Michigan-Dearborn campus on the Fair Lane site. ${ }^{546}$

The oral history program was discontinued, although interviews already in progress were completed, and all transcripts were brought to completion. By July 1960, the company had released most oral history staff or provided them with opportunities to work in other offices. Owen Bombard initially moved to a reference role within the Archives unit before assuming managerial responsibilities in the Company's public relations, publications, shareholder relations, and education departments (he eventually retired in 1980). ${ }^{547}$

Bewick investigated several new homes for the Archives. There was not enough space in Ford's new Administration Building to house the collections; the Highland Park Plant seemed too remote from the Company's main corridor of business operations in Dearborn and at the Rouge; and the estimated $\$ 250,000$ to construct a new building with adequate air-conditioned stacks space was considered too high. Instead, Company officials decided that the Ford Archives could best serve the Company from space in the north wing of the Rotunda building (and at an estimated cost of only \$174,000). ${ }^{548}$

The Rotunda had been renovated and reopened in June 1953 as a centerpiece of the $50^{\text {th }}$ anniversary and served as the gateway for tours of the Ford Rouge factory. The Company claimed that half a million people visited the Rotunda in 1952, promoted as the

\footnotetext{
${ }^{546}$ Henry Edmunds to S.W. Morell, June 29, 1956, folder labeled "Plan for Operations 1957," Box 1, Accession 895, BFRC; Head, "From Corporation to Museum," 20-21; "University of MichiganDearborn," Wikipedia, accessed November 25, 2016, https://en.wikipedia.org/wiki/University_of_Michigan\%E2\%80\%93Dearborn

547 T.L. Bewick to S.W. Morrell and Henry Edmunds, "Proposal for Physical Changes to Archives Department;" “Absence Record," June 30, 1960, and July 31, 1960, folder labeled "Administrative Attendance," Box 34, Accession 506, BFRC; and Adkins, "A History of the Ford Motor Company Archives," note 23, 65.

${ }^{548}$ T.L. Bewick to S.W. Morrell and Henry Edmunds, "Proposal for Physical Changes to Archives Department;" and "Scope and Content Note" in the finding aid to Accession 506, BFRC, http://www.dalnet.lib.mi.us/henryford/docs/MillsEdmundsAndNevinsAndHillSeries_Accession506.pdf accessed March 17, 2016.
} 
"world's largest privately-owned industrial museum." It also housed the Ford Motor Company's Public Relations department, to whom the Archives now reported. ${ }^{549}$

While much of the equipment and shelving could be moved (including the fire suppression system employed in the Fair Lane stacks area), the collection had to be reduced. The collections had expanded to more than 11,000 cubic feet by 1956, yet there would be only room for 4,200 cubic feet in the Rotunda. Richard Ruddell was tasked with identifying which materials could be disposed of to reach a 50\% reduction in the Archives' collections. ${ }^{550}$

The reduction was affected through a series of actions. Much of the Ford Motor Company archival material selected for disposal was actually transferred to other units or removed to the Highland Park storage facility. Although a final listing of specific dispositions does not survive, Ruddell's preliminary recommendations show everything from small accessions of cost accounting records (Accession 67, 16 linear feet, 19481949) and Henry Ford's personal purchase requisitions (Accession 213, 20 linear feet, 1931-1945) to larger collections such as executive correspondence (Accession 46, 130 linear feet, 1938-1945), the operations of the Fordson Coal Company in Kentucky (Accession 444, 250 linear feet, 1915-1936), and Henry Ford's winter residence at the Richmond Hill Plantation in Georgia (Accession 97, 236 linear feet, 1938-1951) being dispersed. Although some of these collections eventually made their way to the Benson Ford Research Center and are open for research today, many of them currently have only a portion of their original contents. The Richmond Hill collection, for instance, was reduced from 236 linear feet to only 1.6 cubic feet, and Accession 46 of executive correspondence was reduced from 130 feet to only 13 cubic feet. There is no indication that the Fordson Coal Company records survive. ${ }^{551}$

\footnotetext{
${ }^{549}$ Quoted section is from Ford Motor Company News Department, "Michigan," May 7, 1953, folder labeled "Dedication Ceremony 1953," Box 3, Accession 506, BFRC. See also Fifty Years Forward, Accession 506, Box 2, BFRC.

${ }^{550}$ Richard Ruddell to Henry Edmunds, August 3, 1956, "Proposed Move of Archives," Box 33, Accession 506, BFRC; Head, "From Corporation to Museum," 21; and Richard Ruddell to Henry Edmunds, "Reduction of Archives' Holdings," July 24, 1956, BFRC.

${ }^{551}$ Finding aid for the Richmond Hill Plantation Record Series, BFRC. Accessed November 21, 2016 http://www.dalnet.lib.mi.us/henryford/docs/RichmondHillPlantationRecordsSeries_Accession97.pdf; see
} 
Other materials were transferred outside of the Ford Motor Company. A collection relating to Henry Ford's 1915 peace expedition was sent to Swarthmore College, and 360 linear feet of bound Detroit newspapers were donated to Wayne State University. Over 500 linear feet of additional book and printed material were identified for disposal, though no record was made of their distribution. Ruddell also attempted to interest the Ford Foundation or Ford Motor Company Fund to support construction of a library at Henry Ford Community College, with the possibility of it becoming the repository for a large collection of moving image film held by the Archives. ${ }^{552}$

The Henry Ford Museum was given first consideration for Ford-related items. Nearly 300 feet of framed photographs, documents, and paintings were transferred. Perhaps most symbolic was the transfer of the Autocar photographic collection to the Henry Ford Museum, acknowledging that the Ford Archives would not become a broad, inclusive automotive heritage collection. ${ }^{553}$

When the Archives finally moved to the Rotunda in February 1957, its program suffered in other ways. Polices were formalized to reduce the amount of new transfers from units within the Company. The new reference room had very limited seating and was cramped with the card catalogs and a portion of the book collection. Only a few staff offices were convenient to the reading room and stacks; most employees were housed in smaller offices on an upper floor. It was a severe change for staff from their salubrious accommodations at the Fair Lane mansion. ${ }^{554}$

Administratively, the Archives Department ceased to be an independent unit. In March 1958 it was merged with the former Graphic and Information Services Department to form a new Research and Information Department. Henry Edmunds became manager of the new unit, reporting to the director of Public Relations. While the Archives had

also description of Accession 46 in OCLC ArchiveGrid accessed November 21, 2016 https://beta.worldcat.org/archivegrid/collection/data/758981049

552 “Oral Reminiscence of Winthrop Sears," [13]; and Richard Ruddell to Henry Edmunds, "Disposition of Historic Film,” October 29, 1958, Box 34, Accession 506, BFRC.

${ }^{553}$ Richard Ruddell to Henry Edmunds, "Reduction of Archives' Holdings," July 24, 1956. BFRC.

${ }^{554}$ Head, "From Corporation to Museum," 22. 
always provided support to Public Relations, it was now an administrative unit within the department. $^{555}$

By 1961, with the closing of the oral history section and reduction of the Archives' function, staffing was reduced to six employees. Winthrop Sears and Alice Benn provided the primary professional staffing. The tenor of their work, however, shifted significantly away from the scholarly clientele, and plans for a national automotive collection including non-Ford materials were forgotten. Edmunds and Ruddell became more involved in handling routine requests from Company personnel for information. They were also responsible for preparing educational materials for schools, printing speeches of Ford executives, and responding to general information queries from the public. In its new location within the PR Department, the former Archives saw an uptick in public requests for information about the Company. The amount of incoming mail was staggering, with the Archives unit fulfilling more than 12,000 requests for information in 1957 - the majority coming from outside the Ford Motor Company. Overall requests to the sister Information Services unit numbered more than 100,000 requests annually. ${ }^{556}$

Archives' staff now became more directly involved in administrative research for the Company's core departments. While staff continued to collect and describe record groups, they also maintained "information on economic forecasts, market analysis and public opinion research." They participated in the creation of Ford Company reports and publications, everything from a financial history of the purchase of the Lincoln Motor Car Company for the Property Accounting department, to the history of the supercharger

${ }^{555}$ Henry Edmunds, "Rough Draft: L.J. Thompson's retirement," April 10, 1958, Box 34, Accession 506, BFRC; Adkins, "A History of the Ford Motor Company Archives," 42; "Oral Reminiscence of Winthrop Sears," [7]; and Head, "From Corporation to Museum," 19.

556 “Absence Record," January 1957, December 1958, June 30, 1960, and July 31, 1960, folder labeled "Administrative Attendance," Box 34, Accession 506, BFRC; Head, "From Corporation to Museum," 19, 22, 24; "Oral Reminiscence of Winthrop Sears," [7-8]; Owen Bombard to Henry Edmunds, "Summary Report of Reference Service, 1957," January 29, 1958, Box 34, Accession 506, BFRC; and Clive Summers to Henry Edmunds, "Number of Requests Answered by Information Services," [February 1958], Box 34, Accession 506, BFRC. 
on automobile engines for the Technical Services Laboratory, as well as a history of safety features which the General Counsel office used in a damage suit. ${ }^{557}$

Other projects drew staff further afield. Edmunds ended up coordinating a reenactment of a coast-to-coast endurance race, including securing a Model T, preparing press packets, and contacting media outlets along the route. References also indicate that the department operated a self-serve public relations library for Company staff on the ninth floor of the Central Office Building. ${ }^{558}$

A microfilming project began in 1962, ostensibly to create preservation copies of some of the most important materials in the Ford Archives, particularly those cited in the Nevins history. Mills and Edmunds assigned greater value to those items, believing that their use by Nevins reflected their historical importance. More than 1,300 feet of records were initially identified for filming, including the Fair Lane Papers, records of Henry Ford's various offices, and property records. Some materials were filmed so that "bulky originals might be destroyed," while other work was completed on "accessions which we contemplate giving away." ${ }^{559}$

The prestige the unit had experienced at Fair Lane during the $50^{\text {th }}$ anniversary had passed. One visitor, having seen the Archives program in 1953 and then again in 1958, remarked how their space had been cut in half - "and their budget even more." Having been renamed the Research and Information Department, the writer continued, they have "shucked the name Archives, which they put into the vocabulary of millions of Americans." 560

To make bad matters worse, on November 9, 1962, a roofing project accidentally caused a fire at the Rotunda building. The central cylindrical part of the building acted as a chimney, and the fire quickly destroyed the primary exhibits, including a popular

\footnotetext{
${ }^{557}$ Head, "From Corporation to Museum," 23; and "Activity Reports," various dates, folders labeled “Activity Reports, 1956-1958 \& 1964," Box 34, Accession 506, BFRC.

558 "Oral Reminiscence of Winthrop Sears," [8] and Head, "From Corporation to Museum," 23.

559 "Top Priority Accessions to Microfilm at Rotunda," November 1962, Box 2, Accession 895, BFRC.

${ }^{560}$ Quoted section is from A.H. Perrin to R.G. Eagen, October 22, 1958, Proctor \& Gamble Archives, Archives General Collection, folder labeled "Archives Correspondence, 1958-1977, Box 266, which is also quoted in Adkins, "A History of the Ford Motor Company Archives," 42. See also "Microfilmed Accessions," March 12, 1964, and Winthrop Sears to Henry Edmunds, November 7, 1962, Box 2, Accession 895, BFRC; and Head, "From Corporation to Museum," 26.
} 
annual Christmas display. Fortunately, the Archives wing was spared the brunt of the damage. Records received only minimal damage, mostly from water used to fight the main blaze and rainfall in the days immediately after the fire. But the Rotunda had to be razed, and the collections moved again. ${ }^{561}$

Records were evacuated to a number of storage locations, including the Highland Park records center and the basement of the Central Office building. Archival staff took a few high-use collections with them to temporary office space on the ninth floor of the same building. The majority of the records, however, were moved to commercial storage warehouses in the local area. The varied locations provided a significant challenge to the staff in locating and retrieving records; the cartons moved to the basement of the Central Office Building were piled to the ceiling. Although the boxes were in numerical sequence with a useable inventory, access required hired men to dig through boxes in search of specific items - a price some Ford offices were unwilling to pay. ${ }^{562}$

Henry Edmunds found the situation extremely frustrating. Observing one particularly difficult search for land abstracts in the scattered collection, he decried how badly the Ford records system had deteriorated:

This is probably a good example of how the dissolution of a central recordkeeping activity and the return of inactive records to points of origin can very quickly turn operating offices into custodial and service operations ... [Y]ou have created dozens of fragmented information operations that would ostensibly require additional space and personnel. You have also burdened current operations with a function that diverts its personnel from their basic job. ${ }^{563}$

The fire prompted another evaluation of Ford's Archives program and consideration of whether the Company received an appropriate return on its investment in staffing and space. The Archives' relevance had faded. Although the unit still responded to requests for research and photograph duplication, it discontinued answering questions from the

\footnotetext{
${ }^{561}$ Winthrop Sears was at the Rotunda the day of the fire and provides a vivid description in "Oral Reminiscence of Winthrop Sears," [9-11]. See also Head, "From Corporation to Museum," 23; and Robert Cotter, "Edison Institute to House Vast Henry Ford Collection," Detroit Free Press, December 31, 1964.

562 "Oral Reminiscence of Winthrop Sears," [11]. Head, "From Corporation to Museum," 25.

${ }^{563}$ Henry Edmunds to P.F. Burns, February 19, 1963, Box 2, Accession 895, BFRC.
} 
public. By April 1963, its primary attention was devoted to whittling down "the pile" of materials hastily withdrawn from the Rotunda "to determine what can be destroyed, which donated or transferred, and which must be retained." New accessions slowed even further, though not completely stopped. What did come to the Archives received only rudimentary description, and much was shipped to the Highland Park storage facility with no description at all. ${ }^{564}$

In May 1963, M.H. Farris, Administrative Systems Manager in the Ford Motor Company Finance Office, issued a concise, three-page report recommending a more aggressive solution: disband the Ford Archives and redistribute the materials. His plan was based on a survey of the collections conducted by Methods Analyst J.R. Wrixom with Archives staff in March and April 1963. The survey reported 13,600 feet of records under the Archives' control, with more than half in spaces in the Central Office building and the rest either at Highland Park or moved into contracted warehouse space following the Rotunda fire. At that point only 56\% of the 888 accessions had been inventoried, though the inventory often represented more of a cataloging process rather than an evaluation of the records with "no effort ... made previously to cull out valueless documents." Wrixom acknowledged "that the Archives has achieved prestige in the professional field as one of the finest collections in industry" and realized the value of the function for public relations research. Yet "the cost of maintaining these records against the benefits derived" remained questionable. ${ }^{565}$

The Farris Report, as it became known, largely recast Wrixom's observations into a simple, business-oriented memo which recommended the dissolution of the Ford Archives. A large portion of the collection - 70\% of the total - could be retained by the Company. These materials would be dispersed to multiple units, but only after a detailed review and evaluation of each record set to identify the few documents which possessed qualities for permanent retention. Most material of lasting value would be integrated into

\footnotetext{
564 Winthrop Sears, "Duties, April 1963," Box 2, Accession 895, BFRC.

565 J.R. Wrixom to M.L. Farris, “Archives Study Progress Report," April 22, 1963, folder labeled "Reports Archives Progress," Box 2, Accession 895; and M.L. Farris to P.F. Burns, “Archives Study,” May 6, 1963, folder labeled “Burns Memo 1963,” Box 1, Accession 895, BFRC.
} 
the Records Management System - and placed into cold storage at the Highland Park records depository. Farris recommended transferring twelve file cabinets of photographic negatives and prints to the News Department. Implying an inappropriate expansion of work assignments to Edmunds and Ruddell, Farris recommended their reassignment "away from the promotion, special events, and program duties" of the Public Relations department. ${ }^{566}$

Farris believed that $30 \%$ of the existing collection could be donated to a local repository. He recommended vetting and removing materials that might be controversial:

This collection would be a valuable addition to any library or museum. It should be reviewed and controversial records, if any, identified. All documents should be microfilmed. After this is done, the controversial documents should be destroyed and the remaining collection should be donated to a library or museum within the Detroit area, for convenient reference of any Company activities. ${ }^{567}$

The primary accessions identified for donation consisted of the personal and office papers of Henry Ford, which Wrixom felt were "not Company records" and would "not be needed for Corporate or administrative purposes." Farris recommended that any documents pertaining to defunct companies (also of no ongoing value to the Company) be either donated or destroyed "after they are screened." 568

The Archives and Public Relations Department were allowed to complete their celebration of the centennial of Henry Ford's birth in June 1963 and work on a Ford exhibit scheduled for the April 1964 opening of the New York World's Fair. Yet, documents throughout these months continued to speak of the "planned disposition of the Ford Archives" to better serve the needs of the Public Relations staff. The effort to dissolve the collections was to be put into effect in the fall of $1963 .{ }^{569}$

\footnotetext{
${ }^{566}$ M.L. Farris to P.F. Burns, "Archives Study."

567 Ibid.

568 Seeing no value for the vast imprint collection of books, periodicals, and trade catalogs, the report included these in the recommendations for disposal. They included complete runs of Company publications and the extensive collection of newspaper clippings the Henry Ford Office had created from 1911-1948. M.L. Farris to P.F. Burns, “Archives Study;" and Head, "From Corporation to Museum,” 27. 569 “Public Relations Program Office,” July 30, 1963, folder labeled “Burns Memo 1963,” Box 1, Accession 895, BFRC.
} 
Not surprisingly, there was an outcry from staff. "This seemed to mean the end of the Archives as a manned research center," recalled Winthrop Sears. "At some point after the Rotunda fire, we knew that the Company did not want to spend money to relocate the Archives." Edmunds pointed out that it was difficult to estimate the likely work required to implement Farris' plan:

Probably no one has ever dissolved so large an archives as this one, so that we have the dubious distinction of pioneering in a new field. There are no precedents to guide us into the most efficient manner of proceeding. For this reason it is difficult for us to forecast our progress in detail. The time required for appraisal and for making arrangements for donation cannot be estimated at this time. We may find that institutions are willing to take some of our records, but lack storage space at present, so that we may have to hold the materials for a time. ${ }^{570}$

Staff estimated it could take two to five years to complete the survey/review of accessions intended for donation outside of the Company. Records in the Highland Park depository were not consistently arranged; materials removed from the Rotunda had been put on pallets, but the pallets were stacked on top of one other, often with other inactive records which were not part of the Archives' holdings. Materials accessioned and inventoried at the box level often contained mixed contents and would require folder-byfolder, or even document-by-document review to "withhold from donation documents which should not be made public." One draft of a dissolution procedural manual spelled out review and removal policies:

E. Remove material putting the Company in an unfavorable light if there are parts of the records which would lend themselves to donation.

F. If accession is not of sufficient historic or philanthropic value and retention is not required, recommend that it be approved for destruction.

G. Determine method of destruction (scrap or confidential). Destruction is accomplished ordinarily by treating material as trash. Confidential material is sealed in cartons and delivered to locked confidential trash room. The material is supposed to be burned in the sealed cartons. ${ }^{571}$

\footnotetext{
570 "Plan of Operation for Period July to December 1963: Disposition of Archives," likely by Henry Edmunds, May 17, 1963, Box 1, Accession 895, BFRC.

571 "Procedure for Evaluation and Disposition of Accessions," undated, folder labeled "Disposal," Box 2, Accession 895, BFRC.
} 
All materials identified for donation required final approval from Ford's general counsel, as well as the departmental source of the material. ${ }^{572}$

Encouraged by Richard Ruddell, Winthrop Sears prepared a response from the Archives staff. "We believed in the usefulness of the collection," Sears recalled later, "and were horrified at the thought of it being censored, broken up, and part of it destroyed." The report consisted of a four-page memo - with an additional 100 pages of appendix material - issued September 20, 1963, above Winthrop Sears' byline (Adkins suggests that it may have been politically advantageous for Edmunds to distance himself from direct authorship). ${ }^{573}$

Sears listed publications which made use of the collections, provided numeric figures for reference requests and photographic duplication, and indicated the myriad of guides and listings which advertised the Ford Archives for scholarly research. He detailed the staff's work in developing more than fifteen card indexes to specific parts of the collections, and argued for the cumulative value of keeping the family papers, Company records, photographs, and published materials together as a single research collection. ${ }^{574}$

Sears also pointed out the likely negative publicity attached to dismantling the Ford Archives, especially since many staff members were active in professional associations. "No one has ever dismantled so large and important a collection," he warned. "This step will be a historic event itself in the archival world and a choice morsel of gossip at academic conventions." Sears saw it as a lack of sincerity - that for Ford, the Archives was only another publicity gimmick, "part of the sales and marketing campaign for 1953." Perhaps most acridly, his report indicated that the Archives was not an "Edsel

\footnotetext{
572 Quoted section about "manned research center" is from "Oral Reminiscence of Winthrop Sears," [12]. See also "Plan of Operation for Period July to December 1963: Disposition of Archives," likely by Henry Edmunds, May 17, 1963, Box 1, Accession 895, BFRC.

${ }^{573}$ Quoted section is from "Oral Reminiscence of Winthrop Sears," [12]. See also Winthrop Sears, "The Ford Motor Company Archives: A Report Outlining its Continuing Importance and Value to the Ford Motor Company," September 20, 1963, folder labeled "Archives Report," Box 2, Accession 895, BFRC; "Scope and Content Note" in the finding aid to Accession 895, Winthrop Sears Records Series, BFRC; and Adkins, "A History of the Ford Motor Company Archives," 46.

${ }^{574}$ Ironically, Sears' work was stymied by poor record-keeping within the Archives itself. Through its short existence, staff had recoded reference statistics in a simple form with little detail on the individuals and departments the Archives had been supporting within the Company. "Oral Reminiscence of Winthrop Sears," [13].
} 
to be dumped if the public doesn't buy" and warned that the Company would "arouse hostility if we close it." ${ }^{, 575}$

As word leaked out about the possible dissolution of the Archives, some hostility did arise. Letters began to arrive from archivists and repositories in the area, sharing their concern about breaking up the collection. It is clear that Allan Nevins urged a letterwriting campaign; several letters, such as an August 1963 letter from the American Historical Association, referenced Nevins' concern that the Ford Archives might not be restored following the Rotunda fire. It is unclear how much of this negative response from scholars and the archival community reached executives, though many were addressed directly to Henry Ford II. ${ }^{576}$

Sears suggested alternative approaches to housing and continuing the program operating a small space with 2,800 linear feet of the most-used collections, with less-used accessions stored remotely. Sears was not against donations to other professionally-run cultural agencies. His report acknowledged previous transfers - and even indicated that the core collections could be transferred to the Henry Ford Museum "as nearly intact as legal considerations will permit." Sears warned the administration that the speed with which Company officials should expect reference and retrieval would slow. ${ }^{577}$

The Company discussed the issue for nearly a year, with varying voices and perspectives informing the argument. While the ongoing debate did slow some cleansing of documents already under way, it did not stop wholesale removal and destruction of many accessions. It is impossible to fully gage what was lost, but a sampling of records destruction reports from January 1963 includes four boxes of case files from the Company's Sociological Department, as well as records of some of Henry Ford's external business interests such as the Dearborn Realty \& Construction Company and the Dearborn Independent, a newspaper he owned and published from 1919 to $1927 .{ }^{578}$

\footnotetext{
575 Sears, "The Ford Motor Company Archives: A Report Outlining its Continuing Importance."

576 Boyd Shafer to Henry Ford II, August 1, 1963, folder labeled "Disposal," Box 2, Accession 895, BFRC.

577 "Possible Solutions," undated, folder labeled "Disposal," Box 2, Accession 895, BFRC; Sears, "The Ford Motor Company Archives: A Report Outlining its Continuing Importance;" and "Oral Reminiscence of Winthrop Sears," [13].

578 "Destruction Reports," Box 2, Accession 895, BFRC.
} 
It is unclear what role Sears' response to plans for dissolution may have had in the discussions, though several passages from his memo appeared in subsequent documents. The Company soon recognized that vetting collections, document by document, presented a prohibitive cost from a staffing resource standpoint. And the cost of the microfilming recommended by the Farris Report was enormous; one internal estimate identified 6,400 linear feet of records to be filmed, comprising probably 7,000,000 individual documents, requiring at least $\$ 300,000$ for labor, machine rentals, and film cost. The filming would take approximately 25 man-years. ${ }^{579}$

While decisions concerning the larger bodies of documents were slowed, initiatives to donate materials to repositories outside the Company proceeded. In most cases, these materials related to defunct companies and Ford initiatives outside the Company's core automotive work - items with no current legal or operating use. For instance, records relating to aviation were given to the Smithsonian Institution, while maritime-related materials were transferred locally to the Dossin Great Lakes Museum on Belle Isle in Detroit. Perhaps most significantly, a large collection of historic moving image film was given to the National Archives. The collection included 1.8 million feet of film, some dating to 1914, which reflected Henry Ford's personal interest in the medium. It included non-Ford materials as well as films produced by the Ford Motion Picture Department, comprising studio films, education pieces, and training movies. The donation was accompanied by a Company donation of $\$ 200,000$ to the National Archives Trust Fund. Ford Motor Company had all donated materials appraised so that it could realize appropriate charitable tax benefits; the motion picture film donation alone was valued at \$3.5 million and provided a \$1.9 million tax credit for the Company. The donations were also intended to garner some good will in the academic community in addition to some favorable publicity. ${ }^{580}$

\footnotetext{
579 "Oral Reminiscence of Winthrop Sears," [13]; and "Findings to Date, A Preliminary Report," December 20, 1963, folder labeled "Disposal," Box 2, Accession 895, BFRC.

${ }^{580}$ A copy of the press release about the film donation by the Ford Motor Company News Department, November 18, 1963, is in Box 1, Accession 895, BFRC; see also Head, "From Corporation to Museum," 26; The Ford Archives, 12; J.R. Wrixom to M.L. Farris, "Archives Study Progress Report;" M.L. Farris to P.F. Burns, "Archives Study;" and Henry Edmunds to T.H. Mecke, September 27, 1962, Folder labeled "Disposal," Box 2, Accession 895, BFRC.
} 
The Edison Institute was obviously interested in the possibility of records transfers including anything relating to the Museum, Henry Ford's personal life, or his interactions with other prominent Americans. Director Donald Shelley asked for, and received, detailed listings from his staff of the types of material they wanted. Librarian Kenneth Metcalf drew from his own research at the Ford Archives and suggested that they attempt to at least acquire the Henry Ford personal papers, if not "all automotive history materials." 581

Museum staff presented themselves as a "Ford interest institution," implying that they might be more sensitive to how the records might be handled or monitored in use by the public. Staff in the two organizations were familiar with each other; the Museum's 1953 exhibit on Henry Ford's life utilized many documents from the Ford Archives and was credited as a joint effort of the two staff. "If these papers go to the Henry Ford Museum," Winthrop Sears indicated in his rebuttal to the Farris Report, "the Museum can be trusted to exercise its discretion." Metcalf noted that other repositories believed donation to the Museum was the obvious course of action. Shelley approached William Clay Ford directly. He shared his staff's concern at news that some material might go to other repositories rather than to the Museum with its "Ford Family tradition." 582

In spring 1964, Ford executives announced their intention to donate the bulk of material comprising the Ford Archives to the Edison Institute to become a permanent part of the Henry Ford Museum. Always attentive to its taxable advantage, the Company arranged to have the collections appraised. The contract was awarded to the Industrial Appraisal Company of Pittsburgh, and their \$92,000 proposed budget included one-time monies to complete some of the microfilming. Staff from Industrial Appraisal surveyed the collections during the summer of 1964. They estimated the size of the collection at 14

${ }^{581}$ Donald Shelley, executive director of the Henry Ford Museum, to William Clay Ford, May 20, 1963, Box 1, Accession 895, BFRC; and Head, "From Corporation to Museum," 28. Quoted section is from Kenneth Metcalf to Donald Shelley, May 16, 1963, folder labeled "Archives Lists," Box 1, E.I. Accession \#57, BFRC. See also M.W. Thomas to Donald Shelley, May 16, 1963, Folder labeled “Archives Lists," Box 1, E.I. Accession \#57, BFRC.

${ }^{582}$ Quoted section is from Sears, "The Ford Motor Company Archives: A Report Outlining its Continuing Importance;" see also Kenneth Metcalf, "General Thoughts on the Ford Archives Situation," May 16, 1963, Folder labeled "Archives Lists," Box 1, E.I. Accession \#57, BFRC. See also Head, "From Corporation to Museum," 28-29. 
million separate items, including 475,000 photographs and a "profuse" number of blueprints. Some materials had already been moved to the Museum, while other documents remained at the Company's Central Office Building and warehouse facilities. Robert F. Metzdorf, an independent appraiser and former curator of manuscripts at Yale, and Edward Lucien, another independent appraiser, conducted the valuation. The final report, dated September 15, 1964, included input from a committee which included pictorial journalist and historian Roger Butterfield, IBM records manager John Porter, and Richmond Williams, director of the Hagley Library in Wilmington, Delaware. ${ }^{583}$

The valuation group faced many challenges, chief being that "no collection of the size and nature of the Ford Archives has previously been sold publicly or privately in this country or elsewhere." Some parts of the collection could be comparatively valued because of the letters of prominent political and historical figures, others from the recognized commercial value of their graphic content. Additional value was also factored in to acknowledge costs incurred by the Company (and its professional staff) in arranging the material. ${ }^{584}$

Industrial Appraisal's final report indicated a net value of nearly $\$ 4.5$ million, describing it as "the largest concentration of important business documents in existence." The appraisers ascribed additional value to keeping the personal and Company papers together; they valued the materials generally at \$2.9 million, but added \$1.5 million on the condition that they were donated as an intact, single collection with all copyright and literary rights. ${ }^{585}$

\footnotetext{
583 Correspondence between Ford Motor Company and the Museum is in folder labeled "Frank Caddy," Box 1, Accession E.I. \#57, BFRC. See also Head, "From Corporation to Museum,” 29; Telling America's Story, 113; Adkins, "A History of the Ford Motor Company Archives," 47; T.H. Mecke to J.E. Lundy, May 25, 1964, folder labeled "Winthrop Sears, FMC Archives (Rotunda) Correspondence, 1964-65," Box 1, Accession 895, BFRC; and Industrial Appraisal Company, "Appraisal of the Ford Motor Company Archives, Dearborn, Michigan,” September 15, 1964, Box 2, Accession 895, BFRC. See also "Oral Reminiscence of Winthrop Sears," [14].

${ }^{584}$ Industrial Appraisal Company, "Appraisal of the Ford Motor Company Archives.

585 Quoted section is from Industrial Appraisal Company, "Appraisal of the Ford Motor Company Archives." See also Head, "From Corporation to Museum," 30; and Adkins, "A History of the Ford Motor Company Archives," 48.
} 
The Company did retain a group of records, notably "certain vital records," observed Jeanine Head, "and confidential legal and financial documents ... retained in order to protect the interests of the Company." A new internal unit, known as the Ford Industrial Archives, was created to manage the retained material with Alice Benn placed in charge. ${ }^{586}$

The bulk of the remaining materials were delivered to the Museum in the final weeks of December 1964 (microfilming was completed in late January 1965, completing a total of nearly 775,000 images). An internal report summarized the total expenses for the creation and operation of the Ford Archives from 1950 through 1964 at more than \$2 million. Although certain elements of the analysis were open to debate - some work completed by Edmunds' staff would have been done by the Public Relations department regardless - the number represented a significant financial investment by the Ford Motor Company in the endeavor. ${ }^{587}$

\section{Combined Collections at the Henry Ford Museum, 1964-1983}

While one might have expected the Edison Institute to integrate the incoming records from the Ford Motor Company with the Institute's existing collections of print and manuscript materials, this was not the case. The formal announcement of the gift of the records in 1963 noted that the Ford Archives would exist as a separate operating division within the Edison Institute. In fact, there were no serious attempts to integrate the various collections residing at the Dearborn Museum location for the succeeding twenty years. ${ }^{588}$

\footnotetext{
${ }^{586}$ Head, "From Corporation to Museum," end note 36; "History of the Ford Archives," typescript chronology; and Adkins, "A History of the Ford Motor Company Archives,"48.

587 Adkins, "A History of the Ford Motor Company Archives," 47; John Dethman to Paul Burns, February 4, 1965, "Completion of Archives Microfilming," folder labeled "Correspondence," Box 1, Accession 895, BFRC; Richard Ruddell, February 4, 1965, folder labeled "Correspondence," Box 1, Accession 895, BFRC; and Memoranda to P.F. Burns (author unknown), August 20, 1964, folder labeled "Correspondence," Box 1, Accession 895, BFRC.

${ }^{588}$ Editor's Corner, Business History Review, 39:1 (Spring 1965), 129. Robert Cotter, "Edison Institute to House Vast Henry Ford Collection,” Detroit Free Press, December 31, 1964.
} 
Meanwhile, the manuscripts held in the Museum Library continued to receive little attention through at least 1977. Jerome Irving Smith was appointed as Librarian at the Museum in 1966 and given oversight of the unit's large collection of imprints and photographs, as well as its small collection of manuscripts. In April 1973, the Museum's library was recast as the Tannahill Research Library in honor of Robert Hudson Tannahill, a former trustee of the Museum board who had been a supporter of the Museum Library. Smith began to proactively gather materials from across the Museum and Village. "[G]reat treasures came out of hiding," Smith noted, from "the most inconceivable corners of the Museum. It was a fantastic revelation, a most challenging time." Smith also extended the Library's intellectual control beyond the walls of the physical Library space to include the exhibition libraries installed in the historic buildings in the Village. ${ }^{589}$

In 1973, the Library collections moved to Lovett Hall, the former dancehall space inside the Edison School's Education and Gymnasium building. Looking back upon this period many years later, librarian Joan Gartland described the Tannahill Research Library as isolated from the parent Edison Institute as well as from other libraries and standard library procedures. "[T]here was puzzlement about what went on in the library, if, in fact, its existence was noted at all," she wrote in 1980. By July 1974, the Library had six employees - three librarians, a library assistant, and two clerical positions - somewhat larger that than the three-person operation of the Ford Archives at that same time. ${ }^{590}$

A few surviving documents indicate that the staff's approach to processing and describing manuscript material in the 1970s wasn't attentive to modern archival practice. Evidence indicates an item-level philosophy following the literary manuscripts tradition. Smith indicated that staff were "busily sorting all the papers into their proper categories"

589 The April 1973 date is specified in Smith, "Preliminary Guide to the Manuscript Collections, (ii-iii). See also Telling America's Story, 123; and Smith, "Robert Hudson Tannahill Research Library," 5, 36.

590 The staff included Smith as chief librarian, David Behmlander, cataloging and research, Edward Kukla, rare books and manuscripts, Lynn McNaughton Ford, Library Assistant, Una Williams, secretary, and Julia Chesley, clerk-typist. See Tannahill Research Library, "Annual Report," [1980], folder 12 "Library Annual Reports, 1978-1981,” Box 5, Accession E.I. \#195, Douglas A. Bakken Records, BFRC; Smith, "Robert Hudson Tannahill Research Library," 37; and Smith, "Preliminary Guide to the Manuscript Collections, (iii). 
- likely obliterating any provenance or original order which may have existed - as their "first step to bring order out of chaos." Smith also described the process of organizing and describing manuscript materials, seemingly at the item level:

[E]ach manuscript will be placed into an acid free folder, identified by the principal name connected with it, dated and then put into a dust free box marked with its rightful classification such as LETTERS, MILITARY PAPERS, REAL ESTATE, CERTIFICATES, LEGAL PAPERS, etc. After that will be the gigantic task of fully cataloguing and cross-indexing the collection so that a complete record of the Library's holdings will be available ... to properly qualified research workers. Actually most of this has been instituted and is now under way. ${ }^{591}$

An extended article in the July 1974 issue of The Herald, a magazine publication distributed to friends of Greenfield Village, provides some of the earliest details of the materials gathered by the Library. The fact that the article fails to even mention the existence of the Ford Archives - which were transferred the Museum ten years earlier is further proof of the separation of the two operations. ${ }^{592}$

\section{A Preliminary Guide to the Manuscript Collections in the Robert H. Tannahill}

Research Library, was issued sometime after April 1973. Jerome Smith's introduction is personal and direct in describing the continuing lack of control over collections:

[I]t is impossible at the present time to describe fully the holdings of this great depository. Therefore at the very start, I wish to make clear that the list of items in our collections which follows is unfortunately only a teaser and more like what would be seen when viewing a magnificent iceberg - only the top shows shining in the sunlight: below is much, much more. ${ }^{593}$

Smith provided small snippets about the collections, describing the Tannahill Library's primary purpose as supporting curators and staff who are "hungrily seeking research sources" to inform their depictions of American history in the Village and Museum. Although the open market provided challenges to purchasing "manuscripts to fill the

\footnotetext{
${ }^{591}$ Smith, "Preliminary Guide to the Manuscript Collections, (iii).

592 Quoted section about "busily sorting" is from Smith, "Preliminary Guide to the Manuscript Collections, (iii). See also Smith, "Robert Hudson Tannahill Research Library," 2-37

${ }^{593}$ Smith, "Preliminary Guide to the Manuscript Collections, (ii).
} 
gaps," additions were made. While it is hard to say exactly what new materials were acquired in particular years, Smith claimed in 1974 that "several thousand items" were acquired annually, making Tannahill one of the "fastest growing facilities of its kind in the United States." 594

Some Tannahill materials Smith mentioned as acquired "in recent years" included a glass formula notebook from the Boston and Sandwich Glass Company (1.6 cubic feet, 1825-1892) and records of an early automobile maker, the Winton Motor Company Carriage Company (0.2 cubic feet, 1897-1928, Accession 73.201.1). Smith's article references a December 1973 donation of more than 10,000 United States, foreign, and United Nations postage stamps by George Trumbull and the Frederic Strum Collection of three thousand eighteenth-century newspapers. ${ }^{595}$

Meanwhile, the Ford Motor Company Archives suffered similar challenges as a separate operating unit within the Museum during this same period, 1964-1977. In addition to limited staffing and resources, the collection endured more severe isolation from other staff of the Edison Institute, some of it self-imposed. The size of the 1964 records transfer was huge; although initial recommendations from the Ford Public Relations department had only identified 2,800 linear feet of accessions to be transferred, the final donation included at least 6,000 feet and later accounts indicate the 1964 donation may have totaled more than 7,000 cubic feet. ${ }^{596}$

These materials were considered by Museum director Donald Shelley to be the "single most important gift to The Edison Institute in its 35-year history." The Museum had to clear its agricultural exhibit for initial arrival, with temporary walls erected to separate the Archives from the public galleries. The Institute provided permanent operating space for the collection in the southwest corner of the main Museum building. It was modest at only 10,000 square feet, including stacks space, an office for the

\footnotetext{
${ }^{594}$ Smith, "Preliminary Guide to the Manuscript Collections, (ii); and Smith, "Robert Hudson Tannahill Research Library," 5.

595 Smith, "Robert Hudson Tannahill Research Library," 13.

596 “Public Relations Program Office," July 30, 1963, folder labeled “Burns Memo 1963,” Box 1, Accession 895, BFRC ; Douglas Bakken, “The Ford Archives: The Next Quarter of a Century,” [1977], 16, folder 4, Box 5, Accession E.I. \#195, BFRC.
} 
director, and a small reading room. There was no separate processing area, and the stacks had limited climate control. Along with the collections, the Company provided a onetime donation of $\$ 52,000$ to the Museum to help defray the costs of processing and servicing the records. The money, however, was barely sufficient to cover the costs of altering space to house the Archives, installing appropriate shelving, and moving furniture and equipment. ${ }^{597}$

Hank Edmunds and Winthrop Sears now became employees of the Henry Ford Museum, along with one clerical assistant. The Ford Archives operated as a separate division within the Edison Institute, with Edmunds as Director. It is not clear if Ford Motor Company provided any funds to support their salaries. This further reduction in staffing (and isolation from their former colleagues in adjacent Company offices) had an immediate impact on the rate at which materials could be unpacked, sorted, reorganized, and shelved. Only in June 1966 was the move complete. ${ }^{598}$

With reference requests increasing, the Institute added an additional archivist in 1969 to assist with reference duties. But the need to support reference work meant little work on improving existing collection guides ("finding aids for the Ford Archives were rudimentary at best"), or creating new ones for unprocessed material. ${ }^{599}$

The Archives' 1969 annual report claimed a shift in emphasis "from a Company orientation into the field of scholarly inquiry." Yet is clear that Edmunds' staff continued to work closely with their former corporate allies. Several documents indicate provision of information to "Ford Motor Company, the Henry Ford Museum, and the public," and at least one indicates the staff had to "prepare research summaries and provide liaison

\footnotetext{
${ }^{597}$ Quoted section about "single most important gift" is from Robert Cotter, "Edison Institute to House Vast Henry Ford Collection," Detroit Free Press, December 31, 1964. Edmunds estimate for these infrastructure changes totaling \$39,300 is in Henry Edmunds to P.F. Burns, September 30, 1964, folder labeled "Correspondence," Box 1, Accession 895, BFRC. See also “Oral Reminiscence of Winthrop Sears," [15]; "History of the Ford Archives," typescript chronology; and Adkins, "A History of the Ford Motor Company Archives," 47.

598 "History of the Ford Archives," typescript chronology; Editor's Corner, Business History Review, 39:1 (Spring 1965), 129; Cotter, "Edison Institute to House Vast Henry Ford Collection,” Detroit Free Press, December 31, 1964; "Oral Reminiscence of Winthrop Sears," [15]; and Head, "From Corporation to Museum," 30.

${ }^{599}$ Quoted section is from Adkins, "A History of the Ford Motor Company Archives," 49; see also Head, "From Corporation to Museum," 31.
} 
between Company and research consultants on special assignments." Jeanine Head noted that "the archives afforded the same prompt reference service to Ford Motor Company staff [as was] extended when the archives was part of the company," and Edmunds and Sears even assisted with Company anniversaries and product introductions. Former archivist Cynthia Read Miller recalled that even after her arrival in the late 1970s, staff answered Company requests immediately. Photographic negatives that the Company wanted to use were physically sent to the lab at the corporate headquarters, rather than to the Museum's onsite dark room. ${ }^{600}$

In the years following the 1963 donation, staff of the Ford Motor Archives and The Edison Institute repeatedly attempted - and failed - to acquire additional records from the Ford Motor Company. Expectations that the big donation of 1963 would be the first in a series of regular transfers of inactive records from the Company to the Archives were soon disappointed. Edmunds had suggested that a three-year schedule for subsequent transfers "would suit the purposes of the Company and also provide a realistic work-load schedule which the Ford Archives could handle." Significant discussion occurred in 1973 and 1974 about the possibility of additional transfers in observance of the Company's $75^{\text {th }}$ anniversary in 1978. The Ford Motor Company's Industrial Archives were still being managed by Alice Benn in 1973 and comprised nearly 4,000 feet of records, with another 2,500 feet of possible interest at the Highland Park repository. But, as in 1963, some Ford executives, fearing transfer of sensitive material, opposed releasing any records "unscreened" to the Edison Institute, as that would be like putting them into the public domain. To no avail, Archives staff continued to assert that the Ford Archives was a "private research archives and not a public library" within the Museum and that they were willing to accept and enforce any specific access restrictions the Company might wish to impose. Staffing also remained an issue - both for processing records and for reference support. Edmunds and Shelley were willing to take on more

\footnotetext{
${ }^{600}$ Quoted section about preparing "research summaries" is from Donald Shelly, "Responsibilities of the Director of the Ford Archives," March 12, 1968, folder labeled "Information About Archives, 19621970," Box 2, Accession 895, BFRC. See also Annual Report, 1969, folder labeled “Archives Annual Reports, 1969-1974," Box 3, Accession 895, BFRC; and Head, "From Corporation to Museum,” 31. Some information is from Cynthia Read Miller, personal interview, August 12, 2016.
} 
material, and a more formal relationship for quick service, as long as the Company provided staffing or funding. And lack of space would have been a significant impediment to any sizeable transfer. Newer personnel within the Ford Motor Company weren't as supportive of records transfers, and some evidence survives that Ford employees were actively weeding Company records of information they deemed to be sensitive or controversial. ${ }^{601}$

Evidence of the stagnation of the Ford Motor Company Archives in the period after 1963 can be found in a booklet about the Archives produced by Edmunds and Robert Bishop, the editor of the Edison Institute's publication unit. Released in 1974, Ford Archives was a 25-page illustrated softbound volume. The booklet was almost a verbatim reprint of the Fair Lane: Ford Motor Company Archives booklet created twenty years earlier for the 1953 Fair Lane dedication event. The 1974 volume claimed that holdings were being "constantly increased from sources outside as well as within the Company," and that "each year thousands of additions ... become part of the permanent collection." Yet, descriptions of the Archives' holdings were repeated word for word from the 1953 booklet with no specific indication of any material which had been added. ${ }^{602}$

${ }^{601}$ Quoted section about "realistic work-load" is from Henry Edmunds to Donald Shelley, May 13, 1974, folder labeled "Edison Institute Correspondence, 1973-1974," Box 52, Accession 506, BFRC. Quoted section about "unscreened" records is from David Crippen to Henry Edmunds, "Messrs. Sears and Crippen's interview with Ron Gould of Ford Motor Company, September 13, 1973," September 14, 1973, folder labeled "Edison Institute Correspondence, 1973-1974," Box 52, Accession 506, BFRC. Quoted section about the archives being a "private research library," is from David Crippen to Henry Edmunds, "Messrs. Sears and Crippen's interview with Ron Gould of Ford Motor Company, September 13, 1973," September 14, 1973, folder labeled "Edison Institute Correspondence, 1973-1974," Box 52, Accession 506, BFRC. "Notes on Highlights of Meeting in Dr. Shelley's Office Between General Services Personnel from Ford and Museum Personnel," September 21, 1973, folder labeled "Edison Institute Correspondence, 1973-1974," Box 52, Accession 506, BFRC. David Crippen noted the appointment of Beverly Prystash to the position of "Records Management Coordinator," indicating that Alice Benn wasn't "overjoyed at the prospect" of reporting to her. Crippen observed that Prystash will be a good contact, but "not now perhaps as sympathetic to the Ford Archives as once might have been." David Crippen to Henry Edmunds, "Beverly Prystash," July 23, 1975, folder labeled "Edison Institute Correspondence, 1973-1974,” Box 52, Accession 506, BFRC. See also Winthrop Sears to Henry Edmunds, January 7, 1974, folder labeled "Edison Institute Correspondence, 1973-1974," Box 52, Accession 506, BFRC; and Bakken, "The Ford Archives: The Next Quarter of a Century."

${ }^{602}$ Robert Bishop to Henry Edmunds, March 23, 1973, Box 52, Accession 506, BFRC; Fair Lane: Ford Motor Company Archives (Bulletin No. 1); Rules Governing Use of Ford Motor Company Archives (Bulletin No. 2); and The Ford Archives, 13, 20. 
Bishop did inject some new material, including a light and conversational "Overview of the Ford Archives" written by Sidney Olson, a section highlighting the Museum's exhibit about Henry Ford's life, and a short "History of the Ford Archives." He also mentioned Edmunds, Ruddell, and other Archives staff, and provided an exterior photograph of Museum wing housing the collection. Just as Jerome Smith failed to mention the Ford Motor Company Archives, Edmunds and Bishop's 1974 booklet made no reference to manuscript and library materials curated elsewhere by the Museum or to the Tannahill Library. A comparison of the 1953 and 1974 publications suggests that little had changed in 20 years - other than a name change Robert Bishop suggested from "Ford Motor Company Archives" to simply "Ford Archives."

It is also clear that Ford Archives staff encouraged separation from the Museum. A July 1969 report referred to the Ford Archives as "a private collection of great public interest." While supporting Museum staff and assisting the public were components of their work, Archives' staff regarded their prime responsibility being to "the originating source of the bulk of our collection, the Company" continuing as gatekeepers to the contents of the Ford Archives, even to other staff in the Museum. As one internal report put it: "There are certain sensitive areas in which great discretion is needed in dealing with researchers." 604

These attitudes persisted even after the Tannahill and Ford collections were moved together into the Education building in 1980, recalled retired archivist Judith Endelman. "They were across the hall, they had two different staffs, and they barely talked to each other." There were two catalogs, two public reading rooms, and a great duplication of effort. When Tannahill librarian Cynthia Read Miller began her employment in the late 1970s, she encountered the protective and isolationist approach of

603 The Ford Archives, 14; and Robert Bishop to Henry Edmunds, March 23, 1973, Box 52, Accession 506, BFRC.

${ }^{604}$ Quoted sections are from uncredited report dated July 1969 in folder labeled "Information About Archives, 1962-1970,” Box 2, Accession 895, Box 2, BFRC. 
Henry Edmunds and Winthrop Sears. She was required to call and make an appointment to access the collections, and her request had to be approved by "Mr. Edmunds." 605

Space continued to be a confining issue for the Ford Archives and was exacerbated by a fire in the main Museum building in August 1970. Although the main stacks area was not directly affected, a secondary storage area was in the path of the fire. More than 50,000 photographs of engineering materials were destroyed, as were early production records for some Ford vehicles and original portraits of Ford family members commissioned from Norman Rockwell. The salvage operations added to the burden of the Archives staff who were already working over capacity. Because of the fire, the Ford Archives lost storage space equivalent to two rooms. In addition, Museum administrators decided to return the Autocar photograph collection back to the Ford Archives. The annual report for 1970 referred to the combination of pressures as a storage crisis, but were largely ignored by the Museum administration. ${ }^{606}$

The best opportunity for integration came in 1977, following the retirements of library director Jerome Smith and archives director Henry Edmunds. Douglas Bakken was hired in August 1977 and formally given responsibility for both the Tannahill Library and the Ford Motor Company Archives, as well as the Museum's publication program. A native of North Dakota, Bakken had earned his master's degree at the University of Nebraska and initially worked as an archivist at the Nebraska State Historical Society. ${ }^{607}$ His career led to Cornell University before he moved to the private sector to work as the administrator of the corporate archives and library for AnheuserBusch in St. Louis. ${ }^{608}$

\footnotetext{
${ }^{605}$ Judith Endelman, personal interview, July 25, 2016; and Cynthia Read Miller, personal interview, August 12, 2016.

606 "History of the Ford Archives," typescript chronology; Head, "From Corporation to Museum," 32-3; Annual Report, 1970, folder labeled "Archives Annual Reports, 1969-1974," Box 3, Accession 895, folder labeled "Archives Annual Reports, 1969-1974," BFRC.

607 "Love of History Led to Ford Archives," Frank Angelo, Detroit Free Press, April 9, 1980. Copy in "Bakken, Douglass," Archives Vertical File, BFRC.

${ }^{608}$ Tannahill Research Library, “Annual Report," [1980], Folder 12 "Library Annual Reports, 1978-1981," Box 5, Accession E.I. \#195, BFRC; "Love of History Led to Ford Archives," Frank Angelo, Detroit Free Press, April 9, 1980; and Head, "From Corporation to Museum," 33-34.
} 
Working with members of the Ford Foundation, Bakken surveyed and reported on the collections in the fall of 1977. Much of his analysis focused on the challenges presented by the Ford Archives. Bakken acknowledged the work of previous staff, but reported that "in the last ten years records were not processed."

[

Previous staff] in no way completed processing of the papers. During the 1960s and 1970s archival techniques instituted and practiced by other repositories were rarely studied and/or implemented at the Ford Archives. Thus a significant back-log exists in terms of modern, archival processing, inventorying and indexing. ${ }^{609}$

He estimated that only 20-30\% of the records had been processed (though current staff claimed that upwards of 65\% were organized and described). He found this to be a result of the "unfortunate decision" of previous staff to emphasize reference service over processing. He estimated a backlog of 3,000-4,000 feet of unprocessed material just from the 1964 donation alone - more work would be necessary with any new donations contemplated in $1978 .{ }^{610}$

The situation was compounded by a lack of space for processing and/or storage. The spaces allotted for the Ford Archives provided no contiguous rooms for convenient growth, so materials were scattered in several spaces, some of them at significant distance from the office and reading room. Bakken managed to carve out a small processing area in one of the adjacent hallways. And he began to get collection processing underway in a more professional and meaningful manner. For instance, a new authority list helped to standardize the local subject headings used to describe collections. Bakken was also able to hire some additional part-time staff to help with the descriptive work. ${ }^{611}$

Bakken appointed Joan Gartland to oversee the Library function in January 1978, and she found things equally awry in the print collection, both in the quality of its

${ }^{609}$ Bakken, "The Ford Archives: The Next Quarter of a Century," 17.

${ }^{610}$ Bakken, "The Ford Archives: The Next Quarter of a Century," 17, 28, 31; and "History of the Ford Archives," typescript chronology.

${ }^{611}$ Head, "From Corporation to Museum," 35. Head references the Ford Archives annual report for 1977 for the hiring of additional staff. Although these reports are now closed to outside researchers, they reside in Box 2, Accession E.I. \#195, BFRC. 
cataloging and in its enormous backlog of unprocessed books. She immediately instituted an inventory of the entire collection to ensure that the card catalog was updated for what was on the shelf. Staff regained control and standardized processes for ongoing cataloging, though portions of the work would need years to complete. Most of the group's remaining energies were directed to re-establishing a reference service and conducting outreach activities to promote use. Gartland acknowledged that lacking a Rare Books and Manuscripts Librarian, it was impossible to accession a small backlog of manuscript items in the Library and that processing of special collections material was at a standstill. ${ }^{612}$

Bakken and Gartland hired Cynthia Read Miller in 1976 as an assistant librarian and cataloger for the Library. She had just completed her graduate training at the University of Chicago; the Ford Museum was her first professional position. Although her primary duties were split between cataloging and reference, she also applied her interest in historical photography to the Library's unprocessed photo collections, including the Detroit Publishing Company collection. Gartland and Miller were active professionally, attending workshops and conferences with the Michigan Library Association, the Special Libraries Association, American College and Research Libraries (Boston meeting), and the Society of American Archivists. In May 1978, Gartland made a trip to Delaware to meet her counterparts and tour the Winterthur and Eleutherian Mills Historical Library. Her report was confined primarily to the other libraries' procedures for handling printed material, which involved, in both cases, a large amount of original cataloging for their specialized holdings. ${ }^{613}$

As Bakken worked to normalize technical functions within each of the units, he also attempted to soften rules for access and use of the collections, lifting outdated requirements for review of materials by the archivist before researchers could have

\footnotetext{
${ }^{612}$ Tannahill Research Library, “Annual Report," [1980], folder 12 "Library Annual Reports, 1978-1981," Box 5, Accession E.I. \#195, BFRC.

${ }^{613}$ Miller later became a curator within the Museum's photographs and prints collection. Cynthia Read Miller, personal interview, August 12, 2016. See also Tannahill Research Library, "Annual Report," January 15, 1980 and Tannahill Research Library, "Annual Report," [1980], both in folder 12 "Library Annual Reports, 1978-1981,” Box 5, Accession E.I. \#195, BFRC; and Joan Gartland to Douglas Bakken, May 22, 1978, folder 12 “Library Annual Reports, 1978-1981,” Box 5, Accession E.I. \#195, BFRC.
} 
access. He expanded contacts with audiences inclined toward the topical contents of the collections and cultivated relationships with automobile clubs and automotive historians. These efforts helped raise awareness of the collections, presented library and archives as parts of a larger whole, and encouraged the idea that the repositories were the appropriate place for other materials to be donated. ${ }^{614}$

Like the Ford Motor Company's 50 ${ }^{\text {th }}$ anniversary in 1953, the Museum's $50^{\text {th }}$ anniversary in 1979 encouraged attention to the Edison Institute's internal records. "Much coordination is needed of archival material in various parts of the E.I.," Winthrop Sears advised, as "questions involving our history come in constantly." The compilation of a commemorative history of the Museum's first half century was stymied by the lack of organized records. This eventually resulted in Bakken's units accepting responsibility for an additional 2,500 cubic feet of Museum-related records and helped to present the Library and Archives as units interested in all aspects of the Museum's work. It also increased space constraints on the Archives, which stymied possible transfers of additional corporate records from the Ford Motor Company. The result was a $\$ 500,000$ commitment by the Ford Motor Company Fund to renovate the former gymnasium in the Education Building to better integrate the Tannahill and Ford Archives programs. But no significant donations of additional Ford Motor Company records followed. ${ }^{615}$

The renovation was informed by field excursions to recently-constructed archives in the region and provided much better efficiencies. The work resulted in four staff offices, a processing room, separate lobby and reading room public spaces, and a staff lounge. The stacks area comprised 30,000 square feet - more than three times the combined size of the previous storage areas. The entire facility was air conditioned, and the stacks had a full sprinkler fire suppression system. The Ford Archives were moved into the new space beginning on March 17, 1980. Staff from both Library and Archives

\footnotetext{
${ }^{614}$ Bakken, "The Ford Archives: The Next Quarter of a Century," Appendix 5; and Head, "From Corporation to Museum," 36.

${ }^{615}$ Quoted section is from Winthrop Sears to Doug Bakken, March 1, 1979, Box 8, Accession E.I. \#195, BFRC (and is also quoted in Head, "From Corporation to Museum," 43). See also Head, "From Corporation to Museum," 36-38; and "History of the Ford Archives," typescript chronology.
} 
assisted each other with the move, and the combined collections were estimated at 10,000 cubic feet of records at the time of the move. ${ }^{616}$

The new space was intended to better integrate the previously separate Library and Archives activities. Bakken finally abandoned use of the phrase "Ford Archives" and promoted the collections as the Museum's “Archives and Research Library.” Historian Jeanine Head indicates that Bakken now began to "actively pursue records and materials related to the automotive industry as a whole," wishing to move the program "once again ... in the direction of becoming a subject-oriented repository." Guides to the photographic collections and archival holdings were published for distribution in 1981 and 1983 (though these publications fail to identify any extensive new additions). Bakken told Museum administrators that the collections had been neglected but contained many "diamonds" - such as the Detroit Publishing Company photographs, the Edison papers, trade catalogs, and other special collections. They needed to be "mined and then subjected to polishing" by more thorough staff work, but Bakken recognized the challenges of relating the Library's collections to the "indoor-outdoor museumeducational-crafts institution" which the Edison Institute had become. ${ }^{617}$

Staffing levels continued to stifle progress in arrangement and description, and more often than not, acquisitions were handled similarly to previous years with little documentation created. Staff continued to "describe and catalog the most important collections first and establish simple controls over the remainder until time and personnel permits a thorough job." 618

Once separated physically and administratively from the Ford Motor Company, the Ford Archives had no formal channels of communication with key Company personnel. Materials continued to be preserved within the Company as part of the Ford

\footnotetext{
${ }^{616}$ Head, "From Corporation to Museum," 39; Tannahill Research Library, “Annual Report,” [1980], folder 12 "Library Annual Reports, 1978-1981," Box 5, Accession E.I. \#195, BFRC; Cynthia Read Miller personal interview, August 12, 2016; and "History of the Ford Archives," typescript chronology.

${ }^{617}$ Quoted sections are from Douglas Bakken to Harold Skramstad, "Tannahill Research Library Report," January 19, 1981, folder 12 "Library Annual Reports, 1978-1981," Box 5, Accession E.I. \#195, BFRC. See also Head, "From Corporation to Museum," 36, 39-40.

${ }^{618}$ Henry Edmunds to Frank Caddy and Robert Wheeler, June 11, 1974, "Edison Institute Correspondence, 1973-1974," Box 52, Accession 506, BFRC.
} 
Industrial Archives. However, the Ford corporate records program faced its own status and resource challenges and maintained a low profile within the Company and the research community through the turn of the century, often staffed by only a single employee. ${ }^{619}$

Bakken was likely frustrated by his failure to develop a working relationship with the Company for additional records transfers. Although efforts to become, through "regularized channels ... the official repository for all significant Ford Motor Company

Table 5.1 - Growth of Collections, Ford Archives, 1951-2017 620

\begin{tabular}{|c|c|c|c|c|}
\hline Date & Source of Information & $\begin{array}{l}\text { Number of } \\
\text { Accessions }\end{array}$ & $\begin{array}{c}\text { Ford } \\
\text { Materials } \\
\text { Cubic Ft. }\end{array}$ & $\begin{array}{c}\text { Total } \\
\text { Cubic Ft. }\end{array}$ \\
\hline Dec. 1951 & Accession Summary & 98 & 2,543 & \\
\hline Apr. 1952 & Edmunds Report & 64 & 4,000 & \\
\hline Sep. 1955 & Fact Sheet & & 7,417 & \\
\hline 1956 & Head & & 11,000 & \\
\hline Jul. 1956 & Ruddell Memo & & 10,270 & \\
\hline Apr. 1963 & Farris Memo (before donation) & & 13,600 & \\
\hline 1964 & Caddy (actually transferred) & & 6,000 & \\
\hline Oct. 1977 & Bakken & & $8,000+$ & \\
\hline Mar. 1980 & Head & & & $\begin{array}{r}\text { nearly } \\
10,000 \\
\end{array}$ \\
\hline 2001 & Terry Hoover & & 10,000 & $>10,650$ \\
\hline Mar. 2015 & Brian Wilson & & 10,763 & \\
\hline Jul. 2017 & Brian Wilson & 1,800 & & 46,000 \\
\hline
\end{tabular}

${ }^{619}$ Adkins, "A History of the Ford Motor Company Archives," 28, 48.

${ }^{620}$ December 1951 figures are from “Accession Summary," [likely January 1952]; April 1952 figures are from Edmunds, "The Ford Motor Company Archives," 100; September 1955 figures are from "Holdings (as of September 15, 1955)," folder labeled "Fair Lane Fact Sheets, 1953," Box 1, Accession 895, BFRC; 1956 figure is from Head, "From Corporation to Museum," 21; July 1956 figure is from Ruddell to Edmunds, "Reduction of Archives' Holdings;" April 1963 figure is from Wrixom to Farris, "Archives Study Progress Report," 1; 1964 figure is from Frank Caddy to The Board of Trustees, October 17, 1977, folder labeled "Financial Papers," Box 1, Accession E.I. \#57, BFRC; October 1977 figure is from Bakken, "The Ford Archives: The Next Quarter of a Century," 17; March 1980 figure is from Head, "From Corporation to Museum," 39; 2001 figures are from an article by archivist Terry Hoover which gives extents for most of the larger, named, manuscript collections, though no distinct numeric extent for photograph holdings and institutional archives, Hoover, "Henry Ford Museum \& Greenfield Village Archives;" 2015 and 2017 figures are from current BFRC archivist Brian Wilson, personal communication, July 25, 2017, and August 11, 2017. Wilson indicates that the discrepancy between 2001 and 2017 figures is likely due to unaccessioned and non-manuscript Edison Institute materials, including maps, sheet music, and automotive trade literature which were not counted in the earlier survey. 
records of historic value came to naught," some smaller acquisitions did occur. Sears listed 289 linear feet of accessions received by the Ford Archives between 1964 and November 1973. These materials included 227 feet from sources within the Ford Motor Company. The larger individual accessions were engineering blueprints, surveyors' notebooks, and some expired patents. Most of the remaining material consisted of small accessions of both Ford and non-Ford materials, each measuring less than inch (and in most cases only comprising a few pages). Because these 289 feet represented $\underline{\text { all }}$ accessions by the Ford Archives in the 10-year period 1964-1973, one could say that acquisitions of records from or even about the Ford Motor Company had nearly completely ceased. ${ }^{621}$

As with the previous case studies, it is challenging to locate consistent numeric data concerning the growth of the manuscript collections over time. Some reports, particularly public promotion of the May 1953 opening of the Fair Lane facility, record discrete numbers of items (in that case, 5 million items). Few records following the 1964 donation to the Edison Institute provide reliable whole numbers of the entire manuscript holdings beyond the core Ford materials. Table 5.1 includes some for the more salient numeric data, confirming that these core Ford family and Ford Motor Company materials experienced no significant increase in size between 1964 and 2001.

1983 provides a logical end date for this exploration of the founding and early development of manuscript collections at The Henry Ford. By 1983, through the work of Douglass Bakken, the two collections (the Ford Archives and the Edison Institute Library) had reached an initial point of integration. The departure of key personnel, including Donald Shelley (retired in 1976), Henry Edmunds (retired in 1977), and, especially, Douglass Bakken (departed in 1983 to become director of the archives of the John Ball Foundation in Muncie, Indiana) provide a logical break point. Most of the Benson Ford's significant document accessions had occurred by that time - in fact, most

${ }^{621}$ Quoted section about "regularized channels" is from Head, "From Corporation to Museum," 31; Winthrop Sears to Henry Edmunds, "Accessions logged in since 1964," November 30, 1973, folder labeled "Edison Institute Correspondence, 1973-1974," Box 52, Accession 506, BFRC; Winthrop Sears, "Accessions Since 1964 From Sources Outside the Company," and "Accessioning Done Since Dec. 31, 1964,” folder labeled "Edison Institute Correspondence, 1973-1974," Box 52, Accession 506, BFRC. 
of the key collections were physically in place in Dearborn as early as 1964, following the donation of the Ford Motor Company Archives to the Edison Institute. ${ }^{622}$

\section{Commentary and Conclusion}

The manuscript collecting which resulted in the records currently held at the Benson Ford Research Center provides a useful comparison to the work undertaken at Baker Library, Hagley, and Smithsonian's Museum of History and Technology. The manuscript collection relating to Henry Ford and Ford Motor Company enjoyed only brief periods of status and meaningful support. During the era studied, 1905-1983, manuscripts were generally assigned secondary value by both the Edison Institute and the Ford Motor Company. At the Company, older corporate records were valued primarily for their promotional and public relations value. Thus Company records management policies were inconsistent and record preservation underfunded. At the Edison Institute, manuscript materials were seen as a secondary form of material culture, of lesser value than artifacts, buildings, and artisan crafts and skills to its educational and interpretive goals. Manuscripts "were not high on the list," noted archivist Terry Hoover, unless an important new exhibit called for manuscript items. Nonetheless, the collection that emerged is still one of largest publicly-accessible collections from a single industrial corporation. 623

This research reveals that most of the important manuscript items currently held at the Benson Ford Research Center were identified, acquired, or preserved by the Museum, its Library, the Village, or the Company before 1953. Although manuscript acquisitions have become a more regular part of the Center's program - and important additions have been made in more recent decades - little of significance was added between the 1964 donation of records by the Ford Motor Company to the Museum and the first effective integration of manuscript collections at the Museum which began in 1983.

\footnotetext{
${ }^{622}$ Telling America's Story, 88; and "Historical Note" in the finding aid to Accession 506.

${ }^{623}$ Terry Hoover, personal interview, July 29, 2016.
} 
The manuscript collections preserved at the Benson Ford Research Center at The Henry Ford were heavily influenced by anniversaries, deaths, and retirements. The Edison Institute was established to mark the $50^{\text {th }}$ anniversary of Edison's invention of the light bulb, with milestones in its story marked by gifts timed to the Museum's own $50^{\text {th }}$ anniversary. Henry Ford's death in 1947 and the Ford Motor Company's 50 ${ }^{\text {th }}$ anniversary prompted the creation of the Ford Motor Company Archives in 1953, with Clara Ford's death creating the opportunity to house the collections at Fair Lane. The death of A.K. Mills in 1954 marked the end of the Ford Archives' zenith as a fully-funded corporate activity, while the retirements of archivist Hank Edmunds and librarian Jerome Smith in the late 1970s created cultural changes allowing for a more fully integrated approach to archival administration. The fact that these events mark the ebb and flow of support for the archival program reflects the undue importance placed on personalities, rather than policy, in the approach to collecting Ford-related manuscripts.

The manuscript collections gathered at the Edison Institute were always just a small component of a larger museum program. Unlike the Library of Congress or the National Archives, remarked Judith Endelman, "archives are core to the mission, but it's not the core product" of the Museum. "The primary resources in the Institute's library were there for the Museum curators," recalled Ford Museum photograph curator Cynthia Read Miller, "they were not there for outside researchers." In the case of the Sandwich Glass records, Miller recalled, a curator even kept the collection closed to outside researchers until he completed his dissertation using the collection. Despite this, marketing staff regularly highlighted the size and breadth of the manuscript collections for promotional purposes - and the library and archives program was able to attract a surprising amount of investment in bricks and mortar construction over the period 1929 to 1983. But, as Endleman noted, "manuscript collections don't really bring in money." The manuscript holdings collected by the Edison Institute to support the Museum and Village were relatively small, but varied across the broad thematic topics explored by its 
parent organization. Limited staffing, however, resulted in decreased capacity to arrange and describe these collections. ${ }^{624}$

Meanwhile, the records gathered from 1950 to 1954 as the Ford Motor Company Archives served a primarily promotional purpose. As the $50^{\text {th }}$ anniversary faded, so too did the desire to fully fund the necessary work to organize and describe the materials. Recommendations by Farris and Wrixom to dismantle the Archives in 1963 reflected a new generation of managers with different priorities in the Archives' parent unit, the Public Relations Department. Ultimately echoing Wayne Grover's 1953 comments that "the Ford Motor Company Archives won't sell many Ford cars," the new managers stressed that "we are all in the automobile business ... and not the Public Relations business." They begrudged time devoted to archival support for non-Ford researchers and other activities that did not appear to have measurable bearing on sales or profits. Historian and former Ford Motor Company Archivist Elizabeth Adkins later described it as a move away from work to support "public goodwill about the company" towards a focus on "publicity for new vehicles." A scholarly Archives collection simply did not fit this new direction. Thus the Company donated the majority of its archival records to the Edison Institute in $1964 .{ }^{625}$

The closeness of archival staff to the Ford Motor Company - as donor, as customer, and as financial supporter - made them cautious in their handling of any materials deemed to be sensitive or controversial. This was certainly the case when the collections were a wholly internal administrative unit within the Company, but continued after the 1963 transfer to the Museum. Adkins conjectures that Edmunds and his considerably reduced staff tried to protect "what they regarded as Ford's interests by carefully controlling access to the records." In addition, archival staff provided a

${ }^{624}$ Cynthia Read Miller, personal interview, August 12, 2016; and Judith Endelman, personal interview, July 25, 2016.

${ }^{625}$ Elizabeth Adkins references the rise of the financial "Whiz Kids" that Henry Ford II had brought into the Company following World War II. She indicates that the Archives was likely seen as only a "soft benefit" to the company. See Adkins, "A History of the Ford Motor Company Archives," 45-46 (Adkins references her source for this information as part II.A, 20, Sears, "The Ford Motor Company Archives: A Report Outlining its Continuing Importance"). See also Grover, Fair Lane: A Business Archives; and "Public Relations Program Office," July 30, 1963, folder labeled "Burns Memo 1963," Box 1, Accession 895, BFRC. 
significant level of reference service to Ford employees both before and after the 1963 transfer. This not only furthered the impression of an ongoing corporate archives, but also distracted staff from their core need to arrange and describe the collections. As a result, the Archives between 1963 and 1983 was "characterized by a lack of major development and marked by isolation from the mainstream of the museum's activities." The sense of separation would prove challenging for people working with both functions for several decades. ${ }^{626}$

More might have been expected of the unique "Company-Institute" relationship between the Ford Motor Company and the Edison Institute. Like Hagley and DuPont, Ford company records supported historical promotion and museum experiences at the Edison Institute. Both DuPont and Ford developed records management programs and eventually turned large blocks of older records over to their respective museum and library counterparts. But neither company developed formal transfer agreements with their library or ultimately turned over any significant additional resources after their first large transfers. Yet, as one of the leading figures in the Company's archives pointed out in 1977, "Most corporations have taken the relatively easy step and simply not preserved or made accessible any historical records." Like the du Pont family and its foundations, both the Ford family and the Ford Motor Company have provided substantial financial support to the Edison Institute and the Company's archives and their manuscript collecting activities. ${ }^{627}$

This trend has continued. Elizabeth Adkins referenced very few records moving to the Museum between 1983 and 1995, and current staff only speak of a few big collections acquired from the Company in recent decades. Some of the larger accessions from the Company have been important, such as the Parts Drawings Collection (675 cubic feet, microfiche, 1903-1957, Accession 86.1.1701) and the Ferguson vs. Ford Records (1,000 cubic feet, Accession 90.1.1753), but little of the material identified in

\footnotetext{
${ }^{626}$ Quoted section about "controlling access" is from Adkins, "A History of the Ford Motor Company Archives," 48. Quoted section about "isolation" is from Head, "From Corporation to Museum," 30.

${ }^{627}$ Bakken, "The Ford Archives: The Next Quarter of a Century," 7.
} 
surveys by Edmunds, Ruddell, Sears and others in the 1950s, 1960s, or 1970s has made its way to the Benson Ford Research Center. ${ }^{628}$

Besides its lack of support for the Archives, the Company has also failed to address ongoing internal records issues. Its Ford Industrial Archives became an orphan moving from department to department, often employing a librarian with no formal training in archival theory and practice and failing to maintain pace with any modern records practice. As a result, noted Company archivist Elizabeth Adkins, the first fifty years of the Company "are fairly well documented and accessible to the public," while the "historical record of the next fifty years ... is less complete." 629

In 1995, the Ford Motor Company finally formally acknowledged the Henry Ford Museum as the official and permanent repository for its historical records. Still, it wasn't until planning began for another anniversary celebration - the 2003 centennial commemoration of the founding of the Ford Motor Company - that records issues would be accorded any significant attention by either the Museum or the Company. As in 1953, the anniversary prompted the "re-engineering" of the corporate archives "to serve both the Company's current business needs and the various Centennial projects." The Company authorized a significant survey and plan for its internal corporate archives, creating a formal records program, and hired Elizabeth Adkins to build a new Ford Motor Company Archives program from the historically under-funded Ford Industrial Archives program. In addition, the Company and Museum were later able to successfully collaborate to improve their shared records legacy: in March 2002 they dedicated the Benson Ford Research Center as the new purpose-built home for the manuscript, archival, library, and smaller artifact holdings of The Henry Ford Museum. Judith Endelman recalled that the planning for this truly integrated facility drew the Library and Archives closer. ${ }^{630}$

${ }^{628}$ Adkins, "A History of the Ford Motor Company Archives," 28; and email interview with Brian Wilson, January 18, 2017.

${ }^{629}$ Adkins, "A History of the Ford Motor Company Archives," 27, 48-49.

${ }^{630}$ Quoted section about "re-engineered" is from Adkins, "A History of the Ford Motor Company Archives," 28. See also Adkins, "A History of the Ford Motor Company Archives," 27-28, 49-63. Additional information is from Judith Endelman, personal interview, July 25, 2016. 
Although staffing was rarely adequate, like Hagley, the Ford Archives and Museum employed professionally trained staff whenever possible. Individuals such as Kenneth Metcalf, Henry Edmunds, and Douglass Bakken were active professionally, sharing information about their operations at archival conferences and providing leadership and service to professional associations.

Ending this case study in 1983 is not intended to imply that the Benson Ford has not added new collections in subsequent decades. Judith Endelman was hired in 1986 as librarian and curator of manuscripts to continue Bakken's work of integrating the two collections, resulting ultimately in a complete merger into a single unit. ${ }^{631}$ Collections continued to be acquired in support of the mechanical and industrial thematic interests of the Museum and Village, such as additions to the Wright Brothers Collection (5.2 cubic feet, 1867-2006, Accession 1623), the records of the Boyne City, Gaylord \& Alpena Railroad Company (1901-1975, 23 linear feet, Accession 1615), the papers of designers Bill Stumpf (142 cubic feet, 1913-2006, Accession 2009.141) and Robert Probst (162 linear feet, 1936-1998, Accession 2010.83), the personal papers and documents of automotive collector and historian Henry Austin Clark (10.4 cubic feet, 1852-1990, Accession 1764), and collections from furniture manufacturers such as Herman Stickley (13.6 linear feet, 1879-1978, Accession 1624), Herman Miller (31 cubic feet, 1923-2006, Accession 89.177), and La-Z-Boy (collection information unavailable for this relatively new accession).

Anecdotal evidence indicates that staff at the Benson Ford Research Center continue to struggle with unprocessed and under-described accessions acquired before 1965 - some gathered by Edmunds in 1951 and others dating almost back to the Museum's founding. Even as late as 1989, archivist Terry Hoover arrived to find "quite a bit of material" still unprocessed and ongoing funding issues preventing the archives from hiring people to help with processing. Since Adkins' departure in 2009 from the Ford Motor Company, the internal Ford Archives has suffered swings in budgetary, staffing, and administrative support. Some additional Company records have been

${ }^{631}$ Judith Endelman, personal interview, July 25, 2016. 
transferred under the auspices of a "Ford Historical Resources Collaborative," but the corporation remains guarded in what it is willing to donate to a publicly-accessible archives. ${ }^{632}$

Some staff speak to the challenges of the "Henry Ford" moniker. Not that they don't understand Henry Ford's personal role in creating or gathering much of the manuscript material held today at the Benson Ford Research Center. The regret, if that is the appropriate word, is that the name implies that their manuscripts are only about Henry Ford and the Ford Motor Company. Judith Endelman reflected that this likely discouraged some donors - and some Museum staff - from growing the manuscript collections beyond the Ford story. While it remains hard to separate "Henry Ford, the Museum" and its manuscripts from "Henry Ford, the man," the mission of the Museum and Village have expanded to more broadly explore and interpret aspects of American history. Yet, during its first fifty years, the institution was not successful in broadening its manuscript holdings much beyond the Ford name. Even amongst a more recent acquisitions expansion at the Benson Ford Research Center, the Ford-related collections particularly the larger business and industrial components which Judith Endleman called "the largest publicly-accessible collection of records from a multi-national corporation" remain as the repository's seminal, best known, and highest use collection. ${ }^{63}$

632 Terry Hoover, personal interview, July 29, 2016; and Telling America's Story, 189.

633 Judith Endelman, personal interview, July 25, 2016. 


\section{CHAPTER 6. COMMENTARY AND CONCLUSIONS}

\section{Introduction}

This study has examined factors that influenced the manuscripts collected during the establishment and early development of four leading repositories that have collected records of business, industry, and technology. In many cases, these records represent the only surviving material culture of individual businesses, former factories, or entire industries which have been removed from the physical landscape and archaeological record. The first institution, Baker Library, was the earliest chronologically and gathered archival resources to support faculty and graduate student research into business and economic history at the nation's first graduate school of business. The Hagley Library began as a private research library, initially focusing on the personal papers of P.S. du Pont and records of the companies he led. It merged with a related industrial museum to become a broad, nonprofit, cultural institution with museum, library, and archival collections, supported by endowed corporate funds. Manuscript records were not initially expected to be a core activity of the Smithsonian's Museum of History and Technology (MHT), but came to be collected somewhat haphazardly to understand and interpret the history of science, engineering, and technology, particularly very large objects and complex technological topics. After the period covered in this study, topics such as science, engineering, and technology have declined in prominence as the museum expanded to more comprehensively represent American history. Meanwhile, in Dearborn, Michigan, the Ford Motor Company gathered the personal papers of Henry Ford and the corporate records of the Ford Motor Company for a corporate anniversary. This corporate archive experienced changing access and growth patterns before the company donated a large portion of the records to a related, standalone nonprofit with museum, library, and archival collections, with some support from the corporation and its endowed foundations.

The individual case studies reveal obvious idiosyncrasies. Not surprisingly, each of these repositories - developed over different timelines and in different geographic locations - gathered unique collections. Because of the particular experiences revealed in 
the institutional histories in the previous chapters, it is clear that a number of factors beyond obvious temporal and geographical differences influenced the manuscripts collected. These factors include institution type and mission, the models which inspired their work, the organizational and staffing structures they employed, the collection policies they developed, and their handling of issues relating to collections storage space. It is useful to examine each of these factors and how they influenced the nature of the records collected at each of the four repositories.

\section{Institutional Type and Mission}

At the broadest scale, these four institutions showed the most variation in institution type and the intended uses of their manuscripts. The institutions that housed Baker and Hagley were the most academic in orientation. Baker was physically and administratively located within Harvard University, but Hagley's close affiliation with the University of Delaware provided a similar core of local, engaged academic scholars who used the manuscript collections for serious research. Both repositories saw themselves as focused, private research archives devoted to serious scholarship and presented significant hurdles to more casual users seeking access. Staff at the Ford Archives attempted to mimic this academic style when their facility opened at the Fair Lane location. Although external researchers were not entirely prohibited, applications for access were closely vetted for an acceptable level of "serious and important purpose." However, lacking an associated university or academic institution similar to Baker or Hagley - and controlling access by external scholars much more closely - the Ford Archives failed to develop a broad user group of academic scholars who could support expansion of its collections. ${ }^{634}$

The manuscript collections at Baker initially had a direct connection to the core case method of study at Harvard's graduate business school. Faculty and graduate students collected and studied historical business records to understand the evolution of

${ }^{634}$ Quoted section about "serious and important purpose" is from "Rules Governing Use of Ford Motor Company Archives: Preliminary Draft,” February 1953, Box 33, Accession 506, BFRC. 
business in the United States and the American economy. These interests resulted in a preference for financial and accounting records; other manuscripts, such as engineering drawings and shop floor documentation, were not regularly collected due to the Baker's institutional ties. Meanwhile, scholars using the Hagley's collections - both from the University of Delaware and other programs - arrived with broader questions about business, industrial, and technological history. As a result, Hagley sought a broader range of record formats and types, including photographs, correspondence, and extensive collections of engineering blueprints. The Ford Archives, without an affiliation with an academic institution, was unsuccessful in engaging graduate students in its program. The emergence of ties to academic research at the Smithsonian came after the focus of this study and did not influence manuscript collecting before 1980.

Unlike Baker, manuscript collecting at Hagley, Smithsonian's MHT, and Ford were influenced by associated museum functions. As the primary function of MHT, the museum prompted the initial infusion of federal monetary resources for staff, a building, the purchase of artifacts, and the research, design, and installation of interpretive exhibits. MHT acquired some manuscript items as material culture artifacts to be used in exhibits. But the larger portions of MHT's archival collections developed "on the side" with no deliberate intention, often serving as surrogates for materials such as steamships, bridges, and blast furnaces which could not be systematically collected or easily displayed. Curators in the thematic areas of science, engineering, and technology uncovered extensive manuscript materials as they traveled the country and the visibility and national importance of the museum opened many doors. Many of MHT's curator-collectors considered archival collections as secondary material cultural resources within the larger museum collections. But engineering-oriented curators such as Robert Vogel, Barney Finn, and John White believed they were the only parties interested in preserving much of the manuscript materials they uncovered. Not trusting in the Library of Congress or National Archives to care about this type of ephemera from industry and technology, they felt justified in collecting such materials at MHT themselves. While such altruistic preservation attitudes may be commended, MHT's curators failed to develop useable acquisition or management policies for MHT's manuscript collections. By slowing or 
deflecting serious policy discussions, these same curators may have deliberately intended to distract museum leadership from their unbridled collecting in areas of personal interest. Because their accumulations of manuscripts were not intentionally collected as archival resources for public access (as was the case at Baker and Hagley), MHT staff ignored needs for arrangement or description, were not trained in these procedures, and were wholly unprepared when external researchers sought access to these records.

Hagley provided a more balanced experience between archival and museum functions, with two endowed funding streams initially supporting the two separate functions. Even after their merger, however, each continued to receive balanced attention and continued budget support, and the manuscript program was able to promote itself separate from the museum as a fully-fledged research library and archives.

Henry Ford's antiquarian interest in Americana included manuscript material, yet the archival collection developed within the Henry Ford Museum was relatively small. Before the 1960s, these meager holdings were housed in a poorly funded library supporting the Edison Institute's children's school, largely lost within the institution's museum, village, and educational programs. Museum staff were primarily interested in these documents as historical artifacts, bearing signatures of famous Americans and fitting into a celebratory framework of events such as the United States' bicentennial year. The Ford Motor Company records received only slightly better treatment after their transfer to the Museum in 1964. A few trained archival staff were also transferred, but the manuscript collections had no obvious value to, or purpose in, the larger and primary mission of the Museum and Village. As with MHT, it would take many decades for manuscript collections at Ford to receive anything near the budgetary support or institutional value that manuscript programs were assigned at Hagley.

Baker Library was never closely associated with a larger museum venture like Hagley, MHT, or Ford. Other than housing a few three dimensional monetary specimens and a brief partnership with the Railroad History Society (which included a small "exhibit room'), Baker never suffered the significant tensions, distractions, or competition for resources from an associated museum like the other three repositories. 
Affiliation with a museum had both benefits and drawbacks for manuscript acquisition. The healthy staffing levels and acquisition budgets at an institution like MHT certainly created a "golden era" for collecting, even if it unfolded with little deliberate planning or active oversight. In fact, the lack of any controlling policy actually encouraged curators like Vogel, Finn, and White to feed their appetite for manuscript material. Many important collections in the history of business, industry, and technology survive at MHT as a result. Hagley's successes in manuscript acquisition, like MHT's, was the result of reliable funding streams. If it weren't for the significant financial support received from the du Pont family and the DuPont Company, Hagley's manuscript experience would likely have been more akin to that at the underfunded Henry Ford museum. ${ }^{635}$

Institutions with both museum and archival functions often presented a better face to donors. Hagley, MHT, and Ford were able to accept mixed donations of both artifacts and manuscript items, such as Vogel's acquisitions from the Nordberg Manufacturing Company and the mixed materials of the La-Z-Boy furniture company acquired more recently by The Henry Ford. And it appears that the broader mixture of historians, curators, and interpretive specialists with librarians and archivists at institutions having both museum and manuscript functions may have supported more holistic perspectives on the material culture of business, industry, and technology which, in turn, encouraged acquisition of a broader range of manuscript formats than the focus on financial and accounting records at Baker.

On the negative side, manuscript collections sometime did not fare well in the competition for staff and funds in museum-archives combinations. This was certainly the case at MHT after the early 1980s. And the Ford archives has never received more than a small fraction of the funding that goes into the museum function of The Henry Ford.

Similarly, these four case studies reveal the benefits and pitfalls which manuscript repositories have encountered in their associations with corporations and business people.

${ }^{635}$ Quoted section about a "golden era" is from "The Life and Times of Robert M. Vogel, Ret.," SIA Newsletter (Fall 1988), 5. 
For Baker Library, insulated by its academic affiliation, these associations were generally positive. Harvard alumni working at active business enterprises not only taught some coursework and hosted graduate student interns, but they also facilitated records donations to Baker Library. Harvard-educated lawyers dealing with bankruptcies, especially during the Great Depression, or with the papers from the estates of deceased business leaders, often guided collections to Baker Library. The Business History Society, and its businessmen members across the country, actively collected and donated manuscript material to Baker.

At Hagley and Ford, ties to businesses had a less favorable outcome, in part because they were heavily dependent on a single corporate entity and industrial personality. They also did not have the protection provided by an academic institution. On the positive side, corporate milestone anniversaries played significant roles in the corporations' decision to create and promote archival collections. At both Hagley and Ford, the personal papers of a founder, his extended family, and the records of associated corporations formed the initial core collections. Both Ford and DuPont experimented with emerging records management systems and developed workflows to control vast amounts of routine records. DuPont was seen as being at the vanguard of such practices by 1957.

The close physical proximity of DuPont's records storage facility, the Hagley industrial museum, and the Eleutherian Mills Historical Library allowed for collegial interplay between corporate, museum, and library staffs, and encouraged the transfer of pre-1902 corporate records. No similar interplay, however, developed at Ford. Individuals like Hank Edmunds and Richard Ruddell were hired from outside the Ford Motor Company and were tasked with rounding up records from various corporate locations. These individuals did not have the skills to differentiate between items of lasting historical value belonging in a permanent archival repository and routine administrative records which should have been handled using internal records management tools. Their desire to establish the Ford Archives at Fair Lane in the style of a private research library proved incompatible with the needs of internal corporate executives and Ford's marketing, public relations, and accounting staff. Corporate 
concerns over protecting Ford's legacy and brand, as well as the lack of a monetary return on the archival investment, undermined Edmunds' hope for a publicly accessible research collection. Following the conclusion of the $50^{\text {th }}$ anniversary celebrations - and the death of Ford Archives' champion A.K. Mills - company officials gutted the program and retreated to a more wholly internal focus. As the Fair Lane concept faded, Edmunds and his staff naturally shifted their mission and goals to those of the corporation. Unfortunately, the resulting culture as gatekeeper employee insiders, rather than objective archivist/historians, continued even after the collections (and these individuals) were "donated" to the Henry Ford museum in 1964.

While helpful, corporate support was not always consistent. From a brick-andmortar perspective ties to corporations were quite useful. The development of manuscript repositories at both Hagley and Ford benefited significantly from corporate and family supporters. In Delaware, Hagley's separate museum and library functions received significant support for facilities. This included the 1955 renovation of P.S. du Pont's former country estate manor house into the Longwood Library to house his family papers and imprints, the 1957 dedication of former DuPont industrial buildings as the Hagley Museum, the 1961 construction of a purpose-built library and archives, and also the 1986 renovation of the Soda House into a standalone archival facility. Ford's Dearborn investment was even more significant when one includes the 1929 dedication of Greenfield Village and construction of the Henry Ford Museum, the 1953 renovation of Henry Ford's former country estate manor house into the Fair Lane Archives to house his family and corporate papers, a number of interim facilities before the 1964 donation to the museum, the 1980 renovation of a former grade school gymnasium to house the Ford Archives, and the 2003 construction of the purpose-built Benson Ford Research Center facility.

However, neither Hagley nor Ford could rely on corporate benefactors. Hagley benefitted from endowment funds, but the Foundations that controlled these funds were managed by individuals outside the library and museum, often active or retired DuPont executives or family members (or both). Charles David and Richmond Williams watched as these external parties imparted directional control over the Hagley's programs, such as 
defining its geographic scope and giving priority to supporting the legacy of the family and corporation. The Ford Archives suffered more serious funding inconsistency following the $50^{\text {th }}$ anniversary celebration in 1953, Mills' death in 1954, and the lack of endowed operating funds. While several critical steps in the survival and evolution of the Ford manuscript collections (particularly the facility investments listed above) benefited from family and corporate philanthropy, this support was neither regular nor assured.

Despite close ties to companies, donations of corporate records were not regular or assured either at Hagley and Ford. Both DuPont and the Ford Motor Company made important initial donations of older business documents, but surprisingly little of any substance thereafter. Despite repeated attempts by staff at the Henry Ford Museum, the publicly accessible collection held today at the Benson Ford Research Center is not much larger than what was donated in 1964 - and certainly no larger than what was held in 1983. Hagley received its original large accession of DuPont records covering the period 1802-1902 as its initial donation in 1957. Although it did accumulate and describe additional materials as a 'Series II' in its 1978 Guide, the material represented only small bits and pieces from the company's vast collection of post-1902 internal records. In both cases, the corporations wished to protect information, limit public access to records, avoid release of any potentially controversial materials, shield themselves from possible litigation, and generally protect a corporate brand. Even without such subsequent transfers, however, the records which DuPont and Ford released to Hagley and the Benson Ford Research Center are significant. Most major American corporations do not release any records to private corporate archives, and records facilities and may not even keep historical records internally.

\section{Models Used}

As pioneers in the collection of business, industrial, and technological records, these four repositories sought inspiration from a variety of contemporary models during their early development. They were also aware of each other's work, with evidence of some interplay and exchange amongst their staffs. 
As the earliest to initiate its manuscript collection - and the first recognizable manuscript repository collecting business records - Baker Library had few models on which to draw. As a library in the Harvard University community, it could emulate basic library procedures at other campus facilities, and its earliest work occurred when the collections were physically located in the Widener Library. Numerous nearby manuscript repositories in Boston, both on- and off-campus, provided obvious examples for collecting and preserving historical records, though many embraced the prevailing literary manuscripts approach. While single items and the smaller collections of pre-1890 bound accounting books could be handled much like imprint collections, staff quickly discovered that these traditional item-level approaches were inadequate to deal with the voluminous financial and administrative records Baker encountered during the expansion period of its manuscript collections. As a result, Baker created seminal procedures for managing such records and became a model for other organizations.

The Hagley - branded initially as the Longwood Library - emulated other private research libraries created by wealthy businessmen and industrialists. P.S. du Pont hoped to mimic institutions such as the Huntington Library, founded by a wealthy railroad tycoon in 1919; the Folger Shakespeare Library, created by a former president of Standard Oil in 1932; and the Morgan Library, founded in 1924 with collections gathered by banking and industrial financier John Pierpont Morgan. Each had evolved from a private collection into an independent research repository with stable endowment funding. The Longwood Library focused on personal papers of the du Pont family, with a large imprint collection providing context to its business and political activity in Europe and early America. P.S. du Pont's desire to contextualize his family's success also included collecting records of other families and businesses for comparison. Following du Pont's death in 1954, Longwood's collecting activity expanded to manuscript acquisitions on a regional scale. As with Baker Library, some initial staff clashes occurred as item-level descriptive systems - such as those preferred by John Riggs with the du Pont family papers - proved laborious and ineffective for Longwood's expanding accessions of industrial records. 
Internally and separately, the DuPont Corporation was also attentive to its history and records. During a period with few extant models, DuPont's internal records management program was lauded in contemporary trade literature, particularly the standalone records storage facility it created in 1945. The scale of its records was dramatic, with some reports indicating a total volume of more than 150,000 cubic feet. When the two operations (Longwood and the Hagley Museum, which had received a portion of the corporation's papers) merged in 1961, the combined manuscript holdings at its purpose-built Eleutherian Mills Hagley Library represented a wholly unique institution: part corporate archive and part private research library, with attachment to an industrial history museum at a nationally significant historic site. The new library drew inspiration from Baker Library, though Hagley staff envisioned its mid-Atlantic manuscript collection partly as a foil to the New England bias created by research and publication from Baker's collections. By the 1970s, business and industrial history - and the collection of related records at the local and regional level - had become a booming business of its own, encouraged by the experience and example of both Baker and Hagley.

The Smithsonian's Museum of History and Technology wasn't intended to include a manuscript repository, so it did not initially seek models for the development of its archival collections. The museum itself drew inspiration from other national industrial museums and international expositions, with artifacts and models gathered to document, interpret, and celebrate technological developments. The fact that MHT's curators adopted no models for manuscript acquisition allowed them a free hand to collect, but resulted in a haphazard and inconsistent archival collection. When the institution belatedly recognized the need to manage its manuscript holdings - both for its own internal use and for an increasing number of external scholars - it initially turned to itemlevel descriptive approaches familiar to those managing museum artifacts. Acquisition of larger manuscript collections, such as the Warshaw Collection of Business Americana, proved this approach untenable, and MHT finally sought the input of professional archivists and created a centralized internal archives center with a modern collectionoriented archives approach. 
In Dearborn, Henry Ford's disdain for contemporary narrative history led to the design of his industrial museum and open air village to provide a more authentic, handson opportunity to explore American history. His boyhood love of the McGuffey Readers spurred his initial interest in imprints and manuscripts. Yet, the small collection of manuscripts gathered as part of the Henry Ford Museum fell well short of aspirational models such as the Huntington Library or the Michigan-based Clements Library and Burton Historical Collections. Meanwhile, the Ford Motor Company created a wholly separate Ford Archives at Fair Lane in 1953, the first time that the corporate archives of a significant, active American business firm had been opened to scholars and the public. Rather than emulating others, the Ford Archives became the model for what a publicly accessible archives of a transparent modern corporation should be. After its initial glory, however, the archives declined both physically and administratively, becoming an internal public relations department for Ford. The collections were divided, and following some scholarly outcry, the company dumped a portion of the oldest records on the Henry Ford Museum. For decades, the Ford Archives struggled to find an identity, either as an internal corporate records collection, or one subsumed in a museum, or a standalone institution.

The manuscript collections associated with Henry Ford and the Ford Motor Company bear many parallels to those at Hagley, but one should not mistakenly assume that du Pont's Longwood Library or the Hagley Museum provided a useful model for the developments in Dearborn. Although the structure of this dissertation placed Ford as the fourth and final case study, its chronology actually intersected those of the other repositories more awkwardly. The creation of the Henry Ford Museum and Greenfield Village in 1929 far predated the founding of either the Longwood Library or the Hagley Museum. In fact, Longwood staff actually visited Dearborn in 1958 to observe what they called "the great Ford project called the Edison Institute." The Ford Motor Company's interest in records management developed along a similar timeline to that at DuPont, and it was also a corporate anniversary - Ford Motor Company's $50^{\text {th }}$ in 1953 , just a year after DuPont's $150^{\text {th }}$ - that initiated the gathering of the Ford records. Hagley and Ford archival staff crossed paths at many points, including Ford's retention of Hagley director 
Richmond Williams for the appraisal of records donated by the Ford Motor Company to the Henry Ford Museum in 1964, yet it appears that their concurrent developmental trajectories failed to create opportunities for either to serve as a definitive model for the other. $^{636}$

Baker Library certainly became the prevailing national model for collecting business manuscripts. Longwood director Charles David publically proclaimed his intention to adapt and repeat Baker's experience with business records in New England in his own expansion of Hagley's collection in the mid-Atlantic region. As the Ford Motor Company contemplated the creation of its archives, it sought the input of Baker Librarian Arthur Cole. Ford's A.K. Mills was not only aware of Baker's pioneering work, but traveled to Boston in 1950 to meet personally with Baker librarians and collect a copy of Cole's 1938 manual for handing business manuscripts (still the seminal work at the time). Curators at Smithsonian also acknowledged the "preeminent" collection of business records at Baker Library and often deflected offers of business records to Boston. By 1954, The American Archivist recognized Baker as representing "the fullest or most complete development of the idea of preserving American business records." These various acknowledgements of inspiration and respect were not without some embedded criticism, however. Hagley's concern about a New England bias in Baker-based scholarship has already been mentioned. But it is also clear that Baker's initial preoccupation with business and economic history, particularly during its early collecting in the 1920s and 1930s, resulted in microappraisal decisions focused upon accounting and other administrative business records. Perhaps ironically, the referrals made to Baker by individuals like Robert Vogel implied some backhanded criticism concerning the limited types of 'business records' of interest to Baker, compared to the broader range of ‘industrial records' sought by institutions like Hagley and Smithsonian. ${ }^{637}$

\footnotetext{
${ }^{636}$ Quoted section about the Edison Institute is from "Minutes," Longwood Library staff meeting, October 24, 1958, 3.

${ }^{637}$ Robert Vogel described Baker Library as "preeminent" in his letter to Richard Bains, August 17, 1979, R.U. 397, Box 13, "Nordberg Collection," Smithsonian Institution Archives. Quoted section about Baker being the "fullest or most complete" is from Oliver W. Holmes, "Some Reflections on Business Archives in the United States," The American Archivist, 17:4 (1954), 291-304.
} 


\section{Organizational Structures and Staffing}

The organizational and administrative structures and staffing choices within each institution, like their institutional contexts and aspirational models, also influenced decision-making on manuscript acquisition and processing. Some structures featured tight control by oversight boards or depended heavily on the personality of directors. Others were more loosely organized, giving staff greater autonomy.

Baker Library developed as a specialized business library within the Harvard School of Business. It utilized a more traditional administrative structure with a strong director. In this academic setting, the selection and hiring of the library director (known simply as the 'Baker Librarian') was under the complete control of the School's dean. Directors were selected for their knowledge and experience in the fields of business and economic history during Baker Library's founding and period of early development. Baker's first director, Charles Eaton, was a Harvard graduate who brought a decade of experience in the business world - and contacts which the School hoped might help the fledgling library. Arthur Cole assumed the director's role in 1929, held a doctoral degree from the Business School, and continued as a professor of business economics after being hired at Baker Library. Even Donald Clark, Baker Library's first key staff person to have college training as a librarian, was required to complete a Harvard MBA before assuming the director's role in 1956. During the creation and expansion phases at Baker, this emphasis on business knowledge certainly helped directors develop and utilize networks of alumni and business leaders, such as the Business Historical Society, to secure donations of imprints, manuscripts, and funds to build the collections. As business scholars and Harvard alumni, Baker's early directors could interact with faculty, alumni, and other researchers as peers. They intimately understood how the library and manuscript collections meshed with the needs of the Business School program. A lack of library training provided challenges in managing a library and its staff, but these directors were able to use their knowledge of business and economic history to inform the administrative work. This was particularly true for Arthur Cole who not only created one 
of the first guides for the care and handling of business manuscripts, but also developed a wholly new classification system for business concepts in a library setting.

It is clear that Baker Library directors held complete authority over acquisition decisions for both imprint and manuscript materials. This resulted in some chaotic collecting by Charles Eaton, but evolved into Cole's more consistent, yet autocratic, management style during his tenure in the position. While admitting that he was "flying blind" when it came to manuscripts, Cole nonetheless developed systems of control which stabilized and rationalized Baker's program. Although Cole eventually released some of his authority to Donald Clark as operational manager in 1940, and Robert Lovett as manuscripts curator in 1948, he maintained close oversight of acquisition decisions until his retirement in 1956. Over three decades, Cole's singular vision for Baker Library's collections influenced what manuscripts were acquired. ${ }^{638}$

P.S. du Pont did not live to see the creation of a private research library housing his family's personal and business records. His death in April 1954 occurred just before Longwood Library hired its first director and three years before Longwood's records were opened for public research. The Longwood Library was administered by the trustees of the Longwood Foundation, which was populated by members of the du Pont family and executives from the DuPont Corporation. It not only managed the endowed funds from the du Pont estate, but was also responsible for selecting Longwood's director. Based on P.S. du Pont's vision of a scholarly research institution, the trustees hired Dr. Charles David, a trained historian with knowledge of topical areas relating to the transatlantic du Pont story, but also a seasoned academic library administrator. David had become Director of Libraries for the University of Pennsylvania in mid-career and had just retired when Longwood's trustees approached him. David, in turn, hired a staff whose key figures were experienced and/or trained librarians.

Drawing on the then prevailing literary manuscripts approach, staff like John Riggs attempted to apply item-level description to Longwood's manuscript collections.

${ }^{638}$ Quoted section about "flying blind" is from Cole, "Some Details on the Determination of The Proper Areas for Collecting Activity at Baker Library," January 16, 1961, 9, 13. 
This proved laborious and time-consuming for the du Pont family papers, delaying publication of the library's first guide to collections for nearly fifteen years. In the meantime, David and his successor, Dr. Richmond Williams, expanded manuscript acquisitions beyond the du Pont story, bringing in larger collections of business, industrial, and technological records from the four-state region surrounding Wilmington, Delaware. Like David, Williams held a doctoral degree in history, rather than in a library field, and arrived with some administrative experience. Williams also acquired knowledge of mid-Atlantic industrial history as director of a large historical society, museum, and library in Wilkes-Barre, Pennsylvania. Arriving at Wilmington in 1961, just as Longwood merged with the Hagley Museum and dedicated its new library building, Williams accelerated acquisitions by creating a 'Specialist in Industrial Collections' position. He selected the individuals employed in this role from 1962 to 1979 for their graduate work in historical disciplines (some from the University of Delaware, Hagley's partner academic institution) and developed with them a manuscript acquisitions program based on systematic surveys of the region's industries and careful study of extant historical records held by other institutions. When the standard library cataloging approaches espoused by Riggs proved increasingly inadequate for the larger collections of records acquired from factories, steel mills, and manufacturing concerns, Williams allowed staff, such as Hugh Gibb, the Specialist for Industrial Collections from 1969 to 1979, to take an active role in the arrangement and description of the records being acquired and to introduce new descriptive approaches in line with emerging national standards - even though they had no professional library training.

Charles David and Richmond Williams managed a large organization with staff involved in book acquisition and cataloging, photo duplication, publications and promotion, programming, and portions of a graduate fellowship program. Each allowed operational staff to manage these functions - and created meeting and reporting structures to allow for staff input in decision-making - yet it is clear that each exerted personal control over the manuscript acquisition program. Each also encountered questions (and sometimes pushback) from Foundation trustees concerning the overarching scope and purpose of the library's archival collections.

Page 318 
The Smithsonian Institution also used a hierarchical approach to staffing its Museum of History and Technology. The museum's executive leadership was provided by a director with a small workforce of assistant directors and clerical staff. The core work of the Museum, however, was carried out by curators with assignments in specific topical areas. Although these topical areas were grouped and structured into individual departments and overarching thematic divisions, the organizational chart was in constant flux as directors and curators frequently realigned staff, artifact collections, and conceptual themes. There was no defined manuscript repository, nor any special staff trained and hired to manage archival material. Instead, individual curators, operating with a great deal of autonomy, identified and acquired manuscript and other reference materials which they found relevant to their research and exhibit needs. These curators came from a variety of backgrounds, most with graduate historical study or work in industry (or both). None arrived with any training or experience in museum or archival settings. MHT utilized committees and work teams to manage broad aspects of the museum's operation - as well as specific exhibit and interpretive projects - but it failed to empower any group to exert any significant control over manuscript acquisitions. As a result, individual curators retained high levels of autonomy and authority, with archival collections added to MHT's holdings with little oversight. This was particularly true for curators in the fields of business, industry, and technology, who felt that manuscript records in these areas were not being preserved by other agencies and whose personal research interests in steam engines, bridges, and electrical power systems required acquisition of archival materials as surrogates for larger objects. While some of these curators may have used the lack of policy to mask inappropriate acquisitions - such as the extensive manuscripts documenting steam power collected by Robert Vogel - it is unlikely that many of MHT's acquisitions before 1983 would have been preserved by other repositories.

When the Ford Motor Company began gathering corporate records for its $50^{\text {th }}$ anniversary, it seated a committee to coordinate a number of projects and commemorative events. The group included a variety of corporate executives who selected A.K. Mills, the former head of Ford's public relations department, to lead the 
work. Mills had no library training or archival experience, but was familiar with Henry Ford's interest in history and was director of the Henry Ford Museum at the time. Mills sought input from a number of external agencies about whom he should put in charge of the archives portion of the project. Some recommended an individual with a research background, recognizing that a central promotional goal was to publish a company history. Staff from the United States National Archives, however, suggested hiring a trained and experienced archivist, seeing the project as needing a solid foundation of records control. Following the latter's advice, Mills selected Henry Edmunds, who brought the perspective of a trained librarian with archival experience at federal agencies and the International Monetary Fund. Edmunds, in turn, hired recent graduates from library and records management programs to assist with the work. It is not clear why Ford anniversary planners did not engage any company employees already working with internal records issues within the company. But with the tacit support of President Henry Ford II, Edmunds and his team began to gather historical records from across the enterprise, including personal papers of Henry Ford discovered at the time of Clara Ford's death.

During the first six years of the effort, 1950-1956, these archivists completed the basic steps involved in creating the archives: locating, identifying, and accessioning record groups, physically transferring records, and developing simple forms of numeric and administrative control. Evidence reflects a frenzied pace, with Edmunds coordinating the group's activities in gathering nearly 11,000 feet of manuscripts. Yet, the pressures of supporting other aspects of the anniversary - including item-level description of photographic material, close interaction with the book publication project and promotional aspects of the anniversary, and dedication of the Fair Lane archival facilitydeferred any detailed arrangement and description of the collections to a later date. A slump in Ford Motor Company finances and the death of A.K. Mills in 1954 undermined corporate support for the archives project. Further processing of records ground to a halt. Following the donation of a portion of the Ford Archives records and staff to the Henry Ford Museum, Edmunds and a single assistant devoted most of their limited capacity to reference service, much of it to Ford Motor Company staff. It was a sad irony that even 
with its employment of trained and experienced archival staff, the Ford Archives remained largely unprocessed through the early 1980s.

Both the Hagley and Ford Archives collections were influenced by individuals associated with their primary corporate donors. Executives and staff drawn from DuPont and Ford, both active and retired, were placed in charge of anniversary celebrations and the family and company foundations which controlled archival and museum budgets. In some cases, these individuals provided useful institution insights and knowledge to the work, such as Frank Battan, P.S. du Pont's personal secretary, who worked in various capacities at Hagley for more than a dozen years, and Madeline Felix, daughter to one of Henry Ford's secretaries, who assisted with the Ford oral history project. But members of the du Pont and Ford families, as well as executives of the active corporations, were protective of the legacies and public image of the families and the companies. Evidence of some censorship - particularly in the case of records relating to Edsel Ford - and the failure of the two companies to transfer any significant subsequent records reflect the influence of family and corporate leaders. In this way, the organizational structure of Hagley and Ford negatively impacted manuscript acquisition.

All four repositories placed significant authority in the hands of single individuals during the early development of their manuscript collections. Smithsonian curators Robert Vogel, Barney Finn, and Jack White at Smithsonian exercised a free hand in their collecting with budgetary support for travel and the shipment of manuscript material to Washington, D.C. Directors such as Arthur Cole at Baker and Charles David and Richmond Williams at Hagley directly controlled manuscript acquisition. Ford executives provided A.K. Mills and Hank Edmunds complete authority to move records to Fair Lane for inclusion in the archives. Staff like John Riggs at Hagley and some corporate records managers at Ford complained about their lack of input in the rapid development of manuscript collections, but such criticisms were either ignored by these aggressive personalities, silenced by management who had appointed the directors, or, in the case of Smithsonian, were deliberately distracted by policy-making initiatives which devolved into meaningless debates concerning the status of manuscripts as material culture objects. 
The aggressive confidence of these key players also served to raise the reputation of these institutions. They were active professionally, serving in leadership roles in professional associations in the fields of library, archives, museum, records management, history, business, economics, industrial heritage, and other areas. They authored a wide variety of publications - everything from dedication booklets for new archival facilities and collection guides, to scholarly articles in peer reviewed journals and monographic publications. Their collective writings defined the challenges associated with managing the manuscripts of business, industry, and technology and suggested realistic approaches to the selection, arrangement, and description of this emerging thematic collecting area. In the pre-internet era, these publications were also a means to announce acquisitions and help researchers locate collections, as well as promote the institution and attract additional acquisitions. Through this work, individuals such as Arthur Cole, Richmond Williams, Robert Lovett, Robert Vogel, and Henry Edmunds became identified leaders in the fields of business and industrial history and in the preservation of related manuscripts. Whether a function of personal ego or a reflection of dynamic, catalytic personalities, their professional activities and publication records significantly raised awareness about the repositories, their manuscript holdings, and their ongoing collecting interests, thereby encouraging preservation of more of the historical record.

Unfortunately, each of these repositories struggled to secure an adequate number of staff to keep up with the incoming volume of new accessions, particularly during periods of rapid expansion. Although organizational charts and staffing levels are difficult to track consistently, even during times of flush resourcing and staffing, the number of staff specifically committed to working with manuscript materials was relatively small (or, in the case of Smithsonian, nonexistent). Making matters worse, Baker and Hagley had large imprint collections, requiring dedicated librarians and support staff to catalog, shelve, and manage reading room functions.

Any repository will bemoan inadequate staffing levels, but it became a particular problem for these four repositories as they expanded their holdings of twentieth century business records. The sheer volume of available material diverted both Baker and Hagley from their initial plans to collect nationally, but there was still an overwhelming amount 
to consider even within their home regions. Staff faced difficult appraisal/selection decisions in the field, particularly during emergency salvage situations. Often unsure of what to collect and what might be of value to themselves or other researchers, many erred on the side of taking as much as possible. Staff at Baker acknowledged that "no one had the foggiest idea" what they were doing, while those at MHT recalled materials coming in "willy-nilly" with no guidelines or accountability. Lacking strong models, existing guidelines, or adequate staffing with appropriate training, each of these four repositories allowed backlogs of unprocessed manuscript materials to accrue. Often clashes broke out between those with responsibility for collecting and those responsible for processing and describing materials. At Hagley, for instance, John Riggs' manuscript processing unit could not keep pace with the large collections arriving via Richmond Williams and his Specialists for Industrial Collections. Although partly a reflection of Riggs' insular interest in retaining a sharp focus on the du Pont story and partly his distraction with the publication of a guide to collections (and possibly an honest fear that his group could not apply the item-level description he preferred), Riggs ultimately accepted the assistance of Hugh Gibb in processing the newer industrial acquisitions. At MHT, the growing backlog of unprocessed material held in individual curators' offices became an increasing access issue for both staff and external researchers, pushing creation of a centralized archival program with additional new staff to arrange and describe the collections. ${ }^{639}$

Looking at the early development of manuscripts at these four institutions, the organizational structure and staffing approach at Hagley yielded the best results. Although not always perfect, the mixture of staff education and experience in fields of library science, library administration, general aspects of American history, and specific aspects of industrial and regional history allowed for a greater breadth of perspective. Hagley's Specialists for Industrial Collections developed surveys, bibliographies, and conferences to build staff knowledge about regional industrial history and help identify gaps in their holdings. These activities also identified potential donors and collections.

\footnotetext{
${ }^{639}$ Quoted section about "foggiest" is from Cole, "Some Details," 9. Quoted section about "willy nilly" is from Virginia Beets to Brooke Hindle, "Need for Active Archival Committee," March 19, 1976, R.U. 334, Box 47, Folder "Archival Committee," Smithsonian Institution Archives.
} 
Staff responsible for arranging and describing manuscripts made a relatively quick transition from item-level description to collection-oriented methods more appropriate to the volume of incoming industrial records. Hagley staff also maintained professional activity in business, library, and archival organizations, adopted emerging archival management techniques, and shared their own experience through conference presentations and publications. With stable endowment funding, Hagley was able to continue to build its collections, apply more concentrated staff capacity to resolve backlogs, support significant research and publication programs (such as the Hagley Fellows), and broadly brand itself as a public research archives with interests in records of business, industry, and technology. Each of the other repositories only succeeded partially with any of these activities before 1983, and none approached the work as holistically and consistently as Hagley. Each succeeded in gathering and preserving significant collections, but Ford and MHT failed to clarify the purpose and audience for this work and failed to direct any significant staff resources to mounting backlog issues during early developmental phases. At Baker, collecting successes by Arthur Cole, the Business Historical Society, and Robert Lovett - and a greater response to staffing and backlog reduction than Ford or MHT - were leavened by the inward focus of its program toward its own faculty and students. Even today, Baker Library presents the greatest restrictions to public access of these four institutions.

\section{Collection Policies and Appraisal/Acquisition Systems}

During their early development, these four repositories experienced initial periods of quick expansion, during which staff aggressively sought materials for collections. Both Baker and Hagley toyed initially with the idea that their archival holdings could be national in scope.

At Baker, Charles Eaton's initial desire to collect broadly was perhaps understandable as no repository had ever attempted to deliberately collect business materials. The assistance he received from members of the Business History Society quickly revealed the enormous amount of extant material available around the country - 
far more than one repository could collect. Arthur Cole, recognizing the failures and dangers of this approach, quickly established a regional New England geographic boundary, as well as an 1890 temporal boundary (just before cost accounting techniques and duplication technologies caused an expansion of paper records in business enterprises).

At Hagley, Charles David also flirted with the concept of a national scope. Trustees of the Longwood Library clearly recognized the enormous cost of such an endeavor and quickly restricted future acquisitions to an 80-mile radius. Cole, David, and Richmond Williams also brought a historian's analytic and systematic eye to their work. Cole created a classification system for business materials at Baker. Both Baker and Hagley came to treat individual manuscript collections as specimens in a hoped-for systematic representation of business, industry, and/or technology. Even if confined to a specific geographic region, this approach echoed the systematic collections of geological or natural history museums, selecting examples of records from each known business type or industrial sector. Once staff felt there was sufficient coverage of a theme, they deflected offers of new material - unless a 'better' collection was discovered for a theme or industry - in which case the repository might discard or gift materials of 'lesser' value. "Two banks should be sufficient," noted Hagley's Hugh Gibb, and "we don't need any more grist mills." Attentive to gaps in these overarching frameworks, both Baker and Hagley also willingly ignored established geographic boundaries to add a collection representing an industry otherwise absent. During the period of maturity which followed rapid expansion, both programs slowed their acquisitions, and many of their post-1980 acquisitions targeted new and emerging topics, such as aerospace, computing, and the rise of consumer products and marketing. ${ }^{640}$

Unlike Baker and Hagley, neither Smithsonian's MHT nor the Ford Archives developed a systematic approach for their manuscript collections. MHT, though national in scope, failed to establish any workable or enforceable policy to guide or limit

\footnotetext{
${ }^{640}$ Quoted section is from Hugh Gibb to Richmond Williams, August 29, 1969, "Aims of the Specialist in Industrial Collections,” Box 373, Folder “Annual Reports - Industrial Specialist,” EMHFA/RG5.
} 
manuscript acquisitions. Some specific companies or sites were deemed nationally significant for interpretation by the museum - which might include acquiring relevant manuscript material - but there was neither a distinct plan for an archival collection or an overarching goal that manuscript collections comprehensively represent all thematic areas. In Ford's case, at least before 1983, the focus was on Henry Ford, the Ford Motor Company, and certain individuals directly associated with the two. There is some evidence of plans to expand the collections outside of the Ford stories, yet very few external manuscripts were acquired before 1983.

This study was not informed by review of internal donor, registrar, or accession files from any of the four repositories, but there is evidence that each acquired some manuscript materials through purchase. While this may have been minimal at the Henry Ford Museum, the published guides of Baker Library identify hundreds of manuscript collections which were purchased (some by members of the Business History Society), and minutes of Hagley staff meetings indicate several purchased collections. MHT curators still celebrate their early collecting and generous travel and acquisition budgets, though it should be noted that the focus was on acquiring three-dimensional artifacts for exhibit. That said, the Smithsonian paid $\$ 100,000$ for the Warshaw Collection - which Hagley had examined, but declined to purchase. MHT curators traded on the cachet of the Smithsonian name when interacting with donors, but it is likely that the deep pockets of the federal government also led to the purchase of some manuscript materials. Lacking a more thorough review of donor files, however, it is difficult to fully assess the influence that purchased collections had in the overall collecting activity of these institutions.

\section{Facilities and Space}

Collections storage space has been both a defining and confining factor at archival repositories, and was certainly so at the four case study institutions. New buildings with empty shelves often invited poor acquisition decisions. Aristotle observed that nature abhors a vacuum, requiring every space to be filled with something, even if that something is colorless, odorless air. Archival repositories are no different, and in their 
earliest stages of development, when space was plentiful, they often acquired materials voraciously with less concern for quality. At later dates, as spaces became filled, archival leaders faced tougher decisions. Where are we going to house this new accession? Should we discard or completely deaccession an existing collection to make more room? How can we come up with the funds for new or redesigned space?

Even a quick review of the spaces used for manuscript storage at the case study repositories reveals some basic commonalities. During their early years, before creation of a defined and dedicated space, manuscripts were stored in whatever space was available: for Baker, the top floor of Harvard's Widener Library; for Hagley, basements and garages at P.S. du Pont's country mansion; for MHT, the file cabinets in curators' offices, and for Ford, spaces in a former engineering laboratory building. Baker and MHT each enjoyed their biggest physical expansions with the construction of their first permanent homes, Baker in a new library built at the heart of the business school campus in 1927, and MHT with the opening of its museum building in 1964. Neither Baker nor MHT saw any subsequent significant new construction (though both would use offsite storage and expand beyond their initial footprint into additional repurposed spaces elsewhere in their buildings).

The singular relationships that Hagley and the Ford Archives had with their donor families and corporations steered the physical locations of their manuscript collections. Fostered initially as the Longwood Library in the renovated mansion of P.S. du Pont, the manuscript collections of the Hagley moved in 1961 to a purpose-built library adjacent to the historic DuPont powder mills, and then again to a renovated industrial building in 1986. The Ford Archives took a similar, though inverted route, from the renovated mansion of Henry Ford, to the Ford Rotunda building in 1956, to a section within the Henry Ford Museum in 1964, to the renovated Gymnasium building at Greenfield Village in 1980, and finally to its current purpose-built facility in 2002. Staff at both Hagley and Ford dealt with challenges inhabiting renovated historic structures, including the lack of adequate environmental controls, appropriate elevator access, and complicated shelving arrangements. The relationship of manuscript and library collections to the museums operated by both entities added to the challenge. The merger of Longwood and 
Hagley required the new 1961 library to carve out valuable spaces for museum staff and the emerging Hagley Fellows program. Meanwhile, in Dearborn, the arrival of the Ford Archives at the Ford Museum in 1964 was accommodated only by the abandonment and repurposing of a section of the museum's public gallery area.

Once the initial vacuum was filled by the wild collecting of each repository's expansion phase, significant challenges arose within their defined spaces. Processed and described collections often received good quality stacks areas (particularly at Baker and Hagley), but space for unprocessed material - and whatever staff was assigned to complete arrangement and description work - was usually inadequate in size or inconvenient to offices and reading rooms. Each repository made use of offsite storage, some simply in other spaces controlled by their governing institution, but some rented from external storage companies. Both Baker and Hagley discussed or established a temporal cutoff date for their collections - the end of the nineteenth century - to avoid the volume attendant with twentieth century business records and the dramatic implications for storage. Such space implications surely inclined Baker and Hagley toward more systematic collecting policies, encouraging the deaccessioning and disposal of some early accessions to make room for 'better' collections representing similar industrial themes. Evidence also points to many cases where repositories selected limited types or formats for preservation, or sampled voluminous runs of routine records to reduce the space required. Beyond 1983, the cutoff date of this study, evidence indicates subsequent reappraisal projects to address some of the poorer acquisition decisions of the principal players discussed in these four case studies.

\section{Lessons Learned}

What can be learned from this review of the founding and development through 1983 of these four repositories for records of business, industry, and technology? Framed in the context of advice to individuals considering establishing an archive focusing on these thematic areas, one clear suggestion is to establish clear expectations - and in some cases place clear limitations - on the types of manuscripts to be collected, keeping in 
mind the intended users and uses of the materials and the likely level of funding for staffing and space.

A repository must have a focused collection policy to realistically respond to the huge volume of records dealing with business, industry, and technology which may be collected - particularly if one includes the digital records of active corporations. It is simply impossible to collect everything, so a new repository should set a clear scope of collections with specific geographic, temporal, and thematic limits.

At a macro level, it is important to understand how the collections at any single repository relate contextually to the holdings of other repositories. To this end, some thoughtful analysis of the extant holdings of similar records - such as the surveys, field visits, and bibliographies completed by Hagley staff - can help to define a collecting approach that adds to the historical record but avoids competition and duplication of effort with other institutions for available manuscripts.

At the micro level, one should become knowledgeable and set guidelines regarding the myriad of record types and formats that could document the themes a repository selects. Records types include administrative business and finance records, correspondence, production and shop floor records, measured drawings, photographs, moving images, and sound recordings. Some of these pose challenging preservation problems, particularly if they have been stored for decades in disused or abandoned industrial buildings. Others present special storage problems, such as large format blueprints, oversize bound accounting volumes, or glass plate negatives. Once clear acquisition guidelines are set, a repository should remain focused and steadfast in only accepting appropriate and significant record types of enduring value.

It is critical that any repository understand its intended users and the resources they are likely to draw on. The four repositories of this study supported differing communities and audiences during their developmental and expansion periods. Several worked with academic faculty and graduate students in history, some in special programs like the Hagley Fellows, with very serious scholarly interests in industrial history. For these, having directors with a business or historical/academic background provided some assistance in making collection decisions. Several repositories also worked alongside an 
affiliated museum organization that drew on its resources, using manuscript items as exhibit objects, in reference files, or as surrogates for certain types of large objects. The Ford Archives for a long period was used heavily by corporate public relations staff. Each repository struggled at times (and still does) with its ability to support more casual research by nonprofessional historians, buffs, automobile and railroad enthusiasts, and members of the general public. Identifying and engaging core user communities will help steer acquisition guidelines.

While it is understood that a repository can always do more with more money, any repository needs stability in funding. Archives simply do not furnish an appreciable financial return on investment, hence their vulnerability (as in the case of Ford) when too closely tied to an operating company. From these four case studies, the best budget model is Hagley with its endowed Foundation funding. Academic institutions, such as Baker Library's situation within Harvard University, provide lower levels of funding, but value the role of archives in scholarship, provide stable forms of funding, and have lower expectations for financial return from libraries and archives. As a result, a new archive in business, industry, and technology should seek either a hefty endowment or an academic home.

Any archive in this specialized field should carefully select staff appropriate to the work: records managers, librarians, archivists, and historians. The four case study institutions developed manuscript collections before the professionalization of archival work and reflect the variety of challenges faced by staff lacking appropriate models, guidelines, and training or experience with historical records. Problems arose when technical cataloging staff could not keep up with volume of incoming records selected by active (and sometimes well-funded) field acquisitions staff. Again, Hagley may have had the most success by providing adequate numbers of staff from a balanced mixture of backgrounds, education, and experience. This study suggests the importance of having a director with a vision for collecting in business, industry, and technology. A new archives' first director - if the repository envisions rapid early expansion - ideally would have historical training and administrative experience in a library setting. The success of David and Williams at Hagley certainly suggests this direction. After the archive is off 
and running, however, subsequent directors should come from an archival background, as institutional focus will naturally shift from acquisitions (which a historian might better direct) to organization, description, and processing (which a professional archivist is more competent to do). But from the start, any director needs trained line staff to arrange and describe the materials to keep from getting too far behind.

Each of the four repositories encountered different issues with physical space. There are many lessons to be learned here: be wary of historic structures renovated for use as archival facilities and don't allow the visual lure of empty shelves to distract focus from a clear collection policy (and/or don't allow backlogs of less valuable unprocessed accessions to accrue). Even within the confines of historic analog records, there will never be enough space for even selective collecting at a regional level. Ideally, space should be scalable and expandable to allow for ongoing acquisitions. Ultimately, archives don't need to look pretty, but must accommodate sufficient space in convenient locations for collections, staff, processing and conservation work, a public reading room, and, if possible, instruction and public programming. While the allure of placing historical records in historical buildings seems commendable and logical, buildings designed originally as residences, businesses, or factories can rarely be affordably renovated to meet the functional and environmental needs of archives. A visit to the current facilities of the four repositories indicates that the 2002 purpose-built archival facility at The Henry Ford comes closest to the ideal.

Repositories should be wary of close interaction with an operating corporation. It is critical that most active records, of only short-term internal value, should be managed through the corporation's records management program and ultimately disposed. Only records with enduring historical value should be accepted into an archives. Even then, access and use are key issues: are the materials restricted for use only by employees of the company, open to select scholars, or generally open to the public? Most important, will the active company restrict, remove, or destroy sensitive or controversial materials? Finally, as noted above, funding and other support from corporations (including document transfers) should not be counted on. As an archivist from one of these case 
studies indicated to the author informally, it is always easier to accept the records of defunct companies rather than active ones.

\section{Closing Comments}

Hagley is the only example in this study to retain its original mission and purpose with manuscript collections. While staffing and space resources have been challenged at times, Hagley has never wavered in its commitment to manuscripts as its core function. At the Baker Library, faculty and administrators initially thought that manuscripts would be a key resource for the case study method. Over time, other sources were found equally valuable - particularly the current, 'real world' problems presented by corporate leaders in their own enterprises - and graduate students in the School of Business have become less interested in manuscript records. The Baker Library has, nonetheless, continued to expand its manuscript collections, as well as its imprints, finding relevance within a narrow community interested specifically in economic and business history within the Harvard University community and its School of Business.

MHT and the Ford Archives have struggled more than Hagley and Baker with identity and relevance. In the case of MHT, the evolution of the National Museum of History and Technology into the expansive National Museum of American History has transformed an archival collection focused on the history of technology and industry into a much broader historical archive. In some ways, the archive's original identity has been swallowed up. The Ford Motor Company made a significant investment to develop an archive in conjunction with its $50^{\text {th }}$ anniversary. Afterwards - and during a downturn in the corporation's profitability - the value of the archives function lessened and its purpose shifted away from historical research and toward public relations and promotional activities. Its relevance declined even further following the 1964 transfer to the Henry Ford Museum, lost in the many-pronged mission of the larger Edison Institute

enterprise. It would take many decades - and a redirection in branding of The Henry Ford as a museum of innovation - for the Ford records to enjoy greater contextual relevance to its host institution. 
One might question whether enough manuscript material has been preserved which documents business, industry, and technology. From a representative standpoint, it seems so, particularly at a national level (Hagley's Hugh Gibb certainly felt that grist mills were adequately recorded). But it is impossible to preserve adequate primary source material to answer all conceivable historical questions. The study of these four institutions not only helps to understand what has been preserved, but also the factors which have influenced what was not collected - at least not by these specific repositories.

Overall, the collections amassed at these four repositories represent an amazing amount of material on the history of science, technology, business, and industry. From a representative standpoint, sample records of almost any type of American business enterprise are included in at least one of these repositories. With the addition of the records held at the hundreds of other archival repositories in the United States, it is likely that some record of just about any American industry has survived. The rise of data aggregators, such as WorldCat, ArchiveGrid, the Digital Public Library of America, and other web-based search tools, has improved discovery and access to these materials.

The most glaring gaps in the collections of these four repositories before 1983 were in geographic coverage. Even with the presumed national scope of the collections at Smithsonian's MHT, curators were most interested in industries along the eastern seaboard and the manufacturing centers of the Midwest. The regional geographic focus at Baker Library and Hagley provides detailed coverage of the New England and midAtlantic areas, while the pre-1983 holdings of the Ford Archives largely focus on a single automobile corporation. As a result, researchers working on industries in those regions or interested in the Ford Motor Company have the advantage of being able to travel to and complete their research within a single repository. Archives have collected business, industry, and technology records, in other geographic regions of the country, but scholars are more likely to have to visit multiple repositories, each holding limited and poorly organized collections. Many singular collections of specific corporations are preserved in other isolated repositories - and may support a focused graduate research study, for instance - but those pursuing comparative work across multiple companies, industries, 
regions, or temporal time periods will be challenged to find comprehensive collections in a single repository similar to those at Baker Library or Hagley.

This study certainly suggests a myriad of areas for additional study. Obviously, one could explore what has happened in the decades since 1983 at these institutions, and determine how their manuscript collections have evolved. How did each institution change its collection policies, what new acquisitions did it pursue, and for what reasons? What types of reappraisal of earlier acquisitions occurred, and what differing institutional priorities informed decisions to deaccession, give away, or destroy records that previous staff had chosen for preservation? How did the employment of professionally trained archivists influence the program of each repository?

It would be useful to examine and better understand microappraisal practices at each institution, i.e., how staff determined which specific records within a collection should be retained as part of the final processed collection. The current study highlights a few such areas - such as the overarching interest in accounting and financial records at Baker Library - but additional detail about field and salvage operations, decisions made during the processing of specific collections, and specific, subsequent decisions to remove or sample certain records series would add detailed insight to each repository's collections.

Most of this subsequent research will, however, require access to the internal administrative records of these and other repositories. It is ironic that archivists aren't good at selecting, preserving, arranging, describing, and providing public access to information about their own institutional histories. The issue of public access to such internal records deserves further comment. It is perhaps understandable that some donor and accession records are of a confidential nature. But while archival repositories have well-established policies for allowing scholarly access to confidential information they collect from external agents, they do not apply those polices to their own records. It is human nature to be sensitive about potential scholarly critique of past internal practices, particularly as it affects the appraisal, selection - and sometimes permanent destruction of historical records. 
Archivists and archival administrators must avoid becoming overprotective gatekeepers of information about their own policies and practices. An open and honest review of past practice - particularly in areas such as those affecting the voluminous records of business, industry, and technology - will strengthen current and future work, helping to ensure that adequate and appropriate documentation is preserved of these core aspects of North American history.

Finally, and of central importance, this study reinforces the view that archival collections are an important element of the study of industrial heritage. The manuscript resources preserved by these four key repositories have been used in thousands of research projects linked to industrial heritage, from scholarly monographs and journal articles to high school History Day exhibits and television documentaries. In many cases, these records provide both the only surviving pieces of material culture from and the only extant historical information about their subjects - factories which have been razed for shopping centers, industrial sites remediated for condominium complexes, shop floor work practices which no living person can recall, and long-forgotten scientific advances which underpin our technology-driven society. In other cases they provide an essential supplement, enabling greater understanding of what does remain. Thus, understanding the people and institutional contexts that influenced manuscript selection at the four important repositories that are the focus of this study is vital. Whether through conscious, policy-driven structures or less-deliberate, personality-driven approaches, their acquisition decisions have determined the limited archival resources that survive to support the study of industrial heritage today. 


\section{BIBLIOGRAPHY}

\section{Published books and articles}

“A Conversation with Robert Lovett," Harvard Business School Bulletin, 57:1 (January/February 1981), 18-19.

Adkins, Elizabeth, "The Development of Business Archives in the United States: An Overview and a Personal Perspective." The American Archivist, 60 (Winter 1997), 833.

Adkins, Elizabeth, "A History of the Ford Motor Company Archives, with Reflections on Archival Documentation of Ford of Europe's History," in Hubert Bonin, Ford, 19032003: The European History (Paris: P.L.A.G.E.: 2003).

Akers, Nancy, "Metropolitan Life Insurance Archives," Special Libraries, 46:1 (January 1955), 8-10.

Alexander, Edward, Museums in Motion: An Introduction to the History and Function of Museums (Nashville, Tennessee: American Association for State and Local History, 2008).

Alexander, Edward, Museum Masters: Their Museums and Their Influence (Walnut Creek, California: AltaMira Press, 2002).

Altman, Elizabeth, "History of Baker Library," in Abraham Zaleznik, et al., editors, Baker Library and the Harvard Business School, 51-92 (Boston, Massachusetts: Harvard University, Graduate School of Business Administration, 1978), 51-92.

Altman, Elizabeth, "A History of Baker Library at the Harvard Business School of Business Administration,” Harvard Library Bulletin, 29:2 (April 1981), 169-196.

Ambacher, Bruce, "The Modern Archives Institute: A History and Profile of Recent Students." Archival Issues, 18:2 (January 1, 1993), 109-19.

Asher, Glen, "Researching the History of Technology at the Hagley Museum and Library," Technology and Culture, 44:4 (October 2003), 762-777.

Armstrong, John, Directory of Corporate Archives: Some Corporate Members of the Business Archives Council Which Maintain Archive Facilities (London: Business Archives Council, 1985). 
"Autocar Historical Collection Given to Ford Archives in Dearborn, Michigan," Virginia Highway Users Magazine, 22:9 (September 1954), 22-25.

Baer, Christopher, "Salvaging History," Railroad History, No. 192 (Spring/Summer 2005), 76-87

Bailey, Robert, "The Certified Records Managers Program," in Irene Place and David Hyslop, editors, Records Management: Controlling Business Information (Reston, Virginia: Reston Publishing Company, 1982), 323-45.

Baker Library, A Classification of Business Literature, (New York: The H.W. Wilson company, 1937)

Baker Library, Industries List; a Classified List of Industries and Occupations with a Numerical Notation (Boston, Massachusetts: Baker Library, 1949).

Bakken, Douglas, "Corporate Archives Today," The American Archivist, 45:3 (Summer 1982), 279-86.

Barcan, Arthur, "Records Management and the 'Paperwork Age,"” The Business History Review, 29:3 (September 1955), 218-26.

Barrett, James, "Acquisition in Industrial Archives," The American Archivist, 24:3 (July 1961), 333-36.

Bartoshesky, Florence, "Business Records at the Harvard Business School" The Business History Review, 59:3 (Autumn 1985),

Basalla, George, "Museums and Technological Utopianism," in Ian Quimby and Polly Anne Earl, editors, Technological Innovation and the Decorative Arts: Winterthur Conference Report 1973 (Charlottesville, Va., 1974), 355-73, and reprinted in Curator, 17:2 (1974), 105-118.

Bedini, Silvio, "The Evolution of Science Museums," Technology and Culture, 6:1 (Winter 1965), 1-29.

Benedict, Karen, "Business Archives Literature," The American Archivist, 45:3 (1982), $312-14$.

Benedict, Karen, "Collecting Repositories and Corporate Archives: Variations on a Theme?" in O'Toole, editor, The Records of American Business (Chicago: Society of American Archivists, 1997), 349-68. 
Benedict, Karen, A Select Bibliography on Business Archives and Records Management (Chicago: Society of American Archivists, 1981).

Berner, Richard, "Archival Education and Training, 1937 to the Present," in Richard Berner, Archival Theory and Practice, 100-110.

Berner, Richard, Archival Theory and Practice in the United States: A Historical Analysis (Seattle: University of Washington Press, 1983).

Birdsall, William, "Archivists, Librarians, and Issues during the Pioneering Era of the American Archival Movement," The Journal of Library History, 14:4 (Fall 1979), 457-79.

Blouin, Francis, "An Agenda for the Appraisal of Business Records" in Nancy Peace, editor, Archival Choices: Managing the Historical Record in an Age of Abundance (Lexington, Massachusetts: Lexington Books, 1984), 61-79.

Blouin, Francis, "A New Perspective on the Appraisal of Business Records: A Review," The American Archivist, 42:3 (July 1979), 312-320.

Blouin, Francis, "Business and American Culture: The Archival Challenge," in The Records of American Business (Chicago: Society of American Archivists, 1997), 1-9.

Boles, Frank, Selecting and Appraising Archives and Manuscripts (Chicago: Society of American Archivists, 2005).

Bombard, Owen, “A New Measure of Things Past," The American Archivist, 18:2 (1955), 123-32.

Bonin, Hubert, Ford, 1903-2003: The European History (Paris: P.L.A.G.E.: 2003).

Campion, Eleanor, "The Union Library Catalogue," in Riggs, John, editor, Charles Wendell David: Scholar, Teacher, Librarian (Philadelphia: Union Library Catalog of the Philadelphia Metropolitan Area, 1965), 19-24.

Boyd, T. A., "The Charles F. Kettering Archives," Technology and Culture, 5:3 (Summer 1964), 412-15.

Bradsher, James, Managing Archives and Archival Institutions (Chicago: University of Chicago Press, 1989).

Brichford, Maynard, "The Relationship of Records Management Activities to the Field of Business History,” The Business History Review, 46:2 (July 1972), 220-32. 
Brown, John, "When Machines Became Gray and Drawings Black and White: William Sellers and the Rationalization of Mechanical Engineering." IA, 25:2 (1999), 29-54.

Business Archives Council, Guide to Methods of Listing, Indexing and Reporting on Business Archives (London: The Council, 1959).

Butler, Stella, Science and Technology Museums (Leicester: Leicester University Press, 1992).

Cappon, Lester, "Historical Manuscripts as Archives: Some Definitions and Their Application," The American Archivist, 19:2 (April 1956), 101-110.

Chandler, Alfred and Stephen Salsbury, Pierre S. Du Pont and the Making of the Modern Corporation (New York: Harper \& Row, 1971).

Chandler, Alfred, Strategy and Structure: Chapters in the History of the American Industrial Enterprise (Cambridge, Massachusetts, Massachusetts Institute of Technology Press, 1962).

Chandler, Alfred, The Visible Hand: The Managerial Revolution in American Business (Cambridge: Belknap Press, 1977).

"Charter of The Business Historical Society, Incorporated," Harvard Business School Alumni Bulletin, 1:1 (June 1926), 11-16.

Cheape, Charles, Strictly Business: Walter Carpenter at Du Pont and General Motors (Baltimore, Maryland: the Johns Hopkins University Press, 1995).

Clark, Donald, "Business School Archives Holds Secrets of Past," Harvard Business School Alumni Bulletin, 23:6 (Spring 1947), 2-4.

Clark, T. D., "Records of Little Businesses as Sources of Social and Economic History," Bulletin of the Business Historical Society, 19:5 (1945), 151-58.

Clapp, Verner, "Bibliographic Vision," in John Riggs, editor, Charles Wendell David: Scholar, Teacher, Librarian (Philadelphia: Union Library Catalog of the Philadelphia Metropolitan Area, 1965), 35-41.

Cochran, Thomas, “Arthur Harrison Cole, 1889-1974," The Business History Review, 49:1 (Spring 1975), 1-5.

Cochran, Thomas, "New York City Business Records: A Plan for Their Preservation," Bulletin of the Business Historical Society, 18:3 (June 1944), 59-62. 
Cochran, Thomas, Railroad Leaders, 1845-1890: The Business Mind in Action (Cambridge: Harvard University Press, 1953).

Cohen, Marilyn, American Civilization in Three Dimensions: The Evolution of the Museum of History and Technology of the Smithsonian Institution (PhD Dissertation, George Washington University, 1980).

Cole, Arthur, "The Baker Library as a National Research Institution," March 19, 1948, HBS Faculty Publications Files, Baker Library, Harvard Business School (GB2.299).

Cole, Arthur, "Baker Library in 'The Depression," Harvard Business School Bulletin, 11:1 (November 1934), 26-28.

Cole, Arthur, The Birth of a New Social Science Discipline: Achievements of the First Generation of American Economic and Business Historians, 1893-1974 (New York: Economic History Association, 1974).

Cole, Arthur, "Business History and Financial Records," Harvard Business School Bulletin, 8:5 (May 16, 1932), 245-46.

Cole, Arthur, "Business Manuscripts: A Pressing Problem," The Journal of Economic History, 5:1 (May 1, 1945), 51-55.

Cole, Arthur, "Business Manuscripts: Collection, Handling, Cataloging," Library Quarterly, 8:1 (January 1938), 93-114.

Cole, Arthur, "The Committee on Research in Economic History: An Historical Sketch." The Journal of Economic History, 30:4 (December 1970), 723-41.

Cole, Arthur, "Corporation Material in the Business School Library." Harvard Library Notes, (June 1941), 46-53.

Cole, Arthur, "Early Days of the Business School Library," Harvard Library Notes, 3:6 (March 1939), 270-77.

Cole, Arthur, "The Evolution of the Baker Library at the Harvard Business School," 1967, HBS Faculty Publications Files, Baker Library, Harvard Business School (GB2.299).

Cole, Arthur, "The Impact of a Large Collection of Business Literature," Harvard Library Bulletin, 15:2 (April 1967), 180-98. 
Cole, Arthur, "Notes on my Early Experiences with the Library of the Harvard Business School," November 12, 1960, HBS Archives Vertical Files, Baker Library, Harvard Business School (E6C 1960.14).

Cole, Arthur, "Some Details on the Determination of The Proper Areas for Collecting Activity at Baker Library," January 16, 1961, HBS Archives Vertical Files, Baker Library, Harvard Business School (E6C 1960.14).

Cole, Arthur, "Organization and Preservation of Manuscript Collections in the Baker Library of the Harvard Business School," Public Documents with Archives and Libraries, 6 (1938), 380-86.

Cole, Arthur, "Principles for the Selection of Materials for Preservation in Collections of Business Records," Public Documents with Archives and Libraries, 6 (1938), 349-56.

Cole, Arthur, "What Is Business History?" The Business History Review, (36:1) (Spring 1962), 98-106.

Cole, Arthur, and Laurence Kipp, "Baker Library Loses a Helmsman," Harvard Business School Bulletin, 39:2 (April-May 1963), 20-22.

Cole, Arthur, and Margaret Stirling, "Flexibility of the Baker Classification," Special Libraries, 35:6 (August 1944), 333-339.

Coleman, Laurence, Company Museums (Washington, D.C.: The American Association of Museums, 1943).

Cook, Terry, "What is Past is Prologue: A History of Archival Ideas Since 1898, and the Future Paradigm Shift,” Archivaria, 43 (Spring 1997), 17-63.

Cooper, Gail, Air Conditioning America: Engineers and the Controlled Environment, 1900-1960 (Johns Hopkins University Press, 1998).

Copeland, Melvin. And Mark an Era: The Story of the Harvard Business School (Boston: Little, Brown: 1958).

Corning, Howard, "The Collection of the Business Historical Society at Baker Library," Bulletin of the Harvard Business School Alumni Association, 5:4 (April 1, 1929), 149-153.

Cotter, Robert, "Edison Institute to House Vast Henry Ford Collection," Detroit Free Press, December 31, 1964. 
Cox, Richard, American Archival Analysis: The Recent Development of the Archival Profession in the United States (Metuchen, New Jersey: Scarecrow Press, 1990).

Cox, Richard, "American Archival History: Its Development, Needs, and Opportunities," The American Archivist, 46:1 (Winter 1983), 31-41.

Craig, Tracey Linton, "Delicate Balance: Hagley Museum Traces the Impact of Technology and Its Products on Society and the Individual," History News, 37:5 (May 1982),

Cusick, Margaret Ronzone, List of Business Manuscripts in Baker Library (Boston: Harvard University Press, 1932)

Daniels, Maygene, "Records Appraisal and Disposition," in Richard Bradsher, editor, Managing Archives and Archival Institutions (Chicago: University of Chicago Press, 1988), 53-66.

Danton, Periam, “The Library Press,” Library Trends, 25:1 (July 1976).

David, Charles, "The Conservation of Historical Source Material," American Documentation, 7:2 (April 1, 1956), 76-82.

David, Charles, "The Longwood Library," Papers of the Bibliographic Society of America, 51:3, (1957),

David, Charles, "The Longwood Library, Kennett Square, Pennsylvania," Bulletin of the Special Libraries Council of Philadelphia and Vicinity, 22:3 (January 1956),

David, Charles, "Robert Curthose, A Critical Biography" (unpublished dissertation, Harvard University, 1918).

Deiss, William, Museum Archives: An Introduction (Chicago: Society of American Archivists, 1984).

DuPont Company, The History of the E.I. du Pont de Nemours Powder Company: A Century of Success and Dutton's Du Pont.

Dutton, William S., Du Pont: One Hundred and Forty Years (New York: Scribner, 1951).

East, John, "Searching the Museum Studies Journal Literature," Curator, 51:3 (July 2008), 311-317. 
Eastwood, Terry, "Nurturing Archival Education in the University," The American Archivist, 51:3 (Summer 1988), 228-52.

"The Edison Institute's New Building," The Herald (publication of The Edison Institute), 4:23 (December 10, 1937), 3.

“The Editor’s Corner,” Business History Review 36:2 (Summer 1962) 229-230.

“The Editor’s Corner,” Business History Review, 39:1 (Spring 1965), 127-129.

Edmunds, Henry, "The Ford Motor Company Archives," The American Archivist, 15:2 (April 1952), 99-104

Edson, Gary, International Directory of Museum Training (London: Routledge, 1995).

Eleutherian Mills Historical Library, Eleutherian Mills Historical Library; A Record of Its Dedication on 7 October 1961 (Greenville: Eleutherian Mills-Hagley Foundation, 1961).

Eleutherian Mills-Hagley Foundation, The Hagley Museum: A Chronicle of America's Industrial Heritage (Greenville: Delaware, Eleutherian Mills-Hagley Foundation, 1963).

Endelman, Judith, Wendy Metros, and Jeanine Head Miller, Telling America's Story: A History of the Henry Ford (Virginia Beach, Virginia: Donning Co. Publishers, 2010).

Endersby, Linda, Expositions, Museums, and Technological Display: Building Cultural Institutions for the "inventor Citizen" in the Late Nineteenth Century United States (PhD Dissertation, Massachusetts Institute of Technology, 1999).

Eulenberg, Julia, "The Corporate Archives: Management Tool and Historical Resource," The Public Historian, 6:1 (Winter 1984), 21-37.

Evans, Frank, "Modern Methods of Arrangement of Archives in the United States," The American Archivist, 29:2 (April 1966), 241-263.

Fair Lane: Ford Motor Company Archives (Bulletin No. 1) (Dearborn, Michigan: Ford Motor Company, 1953).

Fair Lane: The House and Gardens (Bulletin No. 3) (Dearborn, Michigan: Ford Motor Company, 1953).

Ferguson, Eugene, Bibliography on the History of Technology (Cambridge, Massachusetts: Massachusetts Institute of Technology, 1968). 
Ferguson, Eugene, "Technical Museums and International Exhibitions," Technology and Culture, 6:1 (Winter 1965), 30-46.

Finn, Bernard, "Exhibit Reviews-Twenty Years After," Technology and Culture, 30:4 (October 1989), 993-1003.

Finn, Bernard, "Robert P. Multhauf, 1919-2004," Technology and Culture, 46:1 (January 2005), 265-273.

Fisher, Charles, "The Railway \& Locomotive Historical Society, Inc." Bulletin of the Business Historical Society, 8:5 (October 1934), 77-80.

Fitzpatrick, John, Notes on the Care, Cataloguing, Calendaring and Arranging of Manuscripts (Washington, D.C.: Government Printing Office, 1913).

Fleckner, John, "Reaching the Mass Audience: Business History as Popular History," in O'Toole, editor, The Records of American Business (Chicago: Society of American Archivists, 1997), 327-48.

Fleckner, John, and Spencer Crew, "Archival Sources for Business History at the National Museum of American History," Business History Review, 60:3 (Autumn 1986), 474-486.

Ford Archives, The Ford Archives (Dearborn, Michigan: Greenfield Village and Henry Ford Museum, 1974).

Ford Motor Company, ed., Ford Documents and Photographs (Dearborn, Michigan: The Archives, 1953).

"Frank Taylor: Influential public servant," The Sunday Times, (New York), July 30, 2007.

Genoways, Hugh, "Museum Studies Programs Are Not Prepared for the Ph.D," Curator, 39:1 (March 1996), 6-11.

Genoways, Hugh, and Mary Andrei, Museum Origins: Readings in Early Museum History and Philosophy (Walnut Creek, California: Left Coast Press, 2008).

Gibb, Hugh, The Delaware Railroad (M.A., University of Delaware, 1965).

Gilliland-Swetland, Luke, "The Provenance of a Profession: The Permanence of the Public Archives and Historical Manuscripts Traditions in American Archival History," The American Archivist, 54:2 (Spring 1991), 160-175. 
George Brown Goode, "The Genesis of the United States National Museum," in Annual Report of the Smithsonian Institution for 1897, Part 2 (Washington, D.C.: Government Printing Office, 1898).

Gras, Norman Scott Brien (N.S.B.), "Are You Writing Business History?" Bulletin of the Business Historical Society, 18:4 (October 1944), 73-110.

Gras, Norman Scott Brien (N.S.B.), "Past, Present, and Future of the Business Historical Society" Bulletin of the Business Historical Society, 24:1 (March 1950), 1-12.

Gras, Norman Scott Brien (N.S.B.), "The Value of Research to Business." Bulletin of the Business Historical Society, 3:6 (November 1929), 3-6.

Gras, Norman Scott Brien (N.S.B.), "What Is Business History," Bulletin of the Business Historical Society, 18:4 (October 1944), 87-91.

Grover, Wayne, Fair Lane: A Business Archives, ("An address delivered on the occasion of the dedication of the Ford Motor Company Archives at Dearborn, Michigan on May 7, 1953”) (Dearborn, Michigan: Ford Motor Company, 1953).

Hagley Museum and Eleutherian Mills-Hagley Foundation., The Hagley Museum: A Chronicle of America's Industrial Heritage. (Greenville, Delaware: Eleutherian Mills-Hagley Foundation, 1963).

Hagley Museum and Library, Impressions of Hagley (Wilmington, Delaware: Hagley Museum and Library, 1991).

Hamilton, Earl, "Memorial: Edwin Francis Gay," The American Economic Review, 37:3 (June 1947), 410-13.

Harvard Commission on Western History, The Harvard Commission on Western History (Cambridge, Massachusetts: Harvard University, 1912).

Head, Jeanine, "From Corporation to Museum: The Evolution of the Ford Archives," master's thesis, Wayne State University, 1987.

Hedlin, Edie, Business Archives: An Introduction, (Chicago: Society of American Archivists, 1978).

Henson, Pamela M., “'Objects of Curious Research:' The History of Science and Technology at the Smithsonian," Isis, 90 (1999), S249-S269. 
Henry Ford Museum and Greenfield Village, An American Invention: The Story of Henry Ford Museum \& Greenfield Village (Dearborn, Michigan: The Museum and Village, 1999).

Hidy, Ralph, "Business Archives: Introductory Remarks," The American Archivist, 29: 1 (1966), 33-36.

Hidy, Ralph, and Muriel Hidy, "Henrietta Larson: An Appreciation," The Business History Review, 36:1 (Spring 1962), 33-36.

Hindle, Brooke, "Comment: Museum Reviews and the History of Technology," in Donald Hoke, editor, The History and Sociology of Technology: Proceedings of the Twenty-fourth Annual Meeting of the Society for the History of Technology, Milwaukee, Wisconsin, October 14-17, 1981 (Milwaukee: The Society for the History of Technology, 1982), 200-201.

Hindle, Brooke, "Museum Treatment of Industrialization: History, Problems, Opportunities," Curator, 15:3 (1972), 206-13.

Hirsch, Rudolph and Margaret Nolan, "The Peaceful Revolution,” in Riggs, John, editor, Charles Wendell David: Scholar, Teacher, Librarian (Philadelphia: Union Library Catalog of the Philadelphia Metropolitan Area, 1965), 25-34.

"A Historian with a Sense of Humor" [Henry Edmunds obituary], Detroit Free Press, July 25, 1982.

The History of the E.I. du Pont de Nemours Powder Company: A Century of Success (New York: The Banker and Investor Magazine Publishing Company, 1912).

"History of the Ford Archives," typescript chronology in Archives Vertical File titled "Sears - Chronology," Benson Ford Research Center.

"History of the Ford Archives," The Ford Archives (Dearborn, Michigan: Greenfield Village and Henry Ford Museum, 1974).

Holmes, Oliver, "Archival Arrangement—Five Different Operations at Five Different Levels," The American Archivist, 27:1 (January 1964), 21-42.

Holmes, Oliver, "The Evaluation and Preservation of Business Archives." The American Archivist, 1: 4 (1938), 171-85.

Holmes, Oliver, List of Business Manuscripts in Baker Library, by Robert Lovett, [book review], The American Archivist, 15:2 (1952), 166-68. 
Holmes, Oliver, "Some Reflections on Business Archives in the United States," The American Archivist, 17:4 (1954), 291-304.

Hoover, Terry, "Automotive History Collections: Henry Ford Museum and Greenfield Village," Michigan Historical Review, 22:2 (Fall 1996), 149-53.

Hoover, Terry, "Henry Ford Museum \& Greenfield Village Archives, Manuscripts, Library Holdings, and Special Collections," Michigan Historical Review, 27:1 (Spring 2001), 152-169.

Hounshell, David, “A Guide to Manuscripts in Electrical History," Technology and Culture, 15:4 (October 1974), 626-27.

Hounshell, David, From the American System to Mass Production, 1800-1932: The Development of Manufacturing Technology in the United States (Baltimore, Maryland: Johns Hopkins University Press, 1984).

Hounshell, David, and John Smith, Science and Corporate Strategy: DuPont R and D, 1902-1980 (Cambridge and New York: Cambridge University Press, 1988).

Hower, Ralph, "Old Business Records Wanted," Bulletin of the Harvard Business School Alumni Association, (November 1935), 48-49.

Hower, Ralph, "The Preservation of Business Records," Bulletin of the Business Historical Society, 11:3/4 (November 1937), 37-61.

Hower, Ralph, The Preservation of Business Records (Boston: Business Historical Society, 1941).

Hower, Ralph, "Wanted: Material on the History of Marketing," Bulletin of the Business Historical Society, 9:5 (October 1935), 79-81.

Hudson, Kenneth, A Social History of Museums (Atlantic Highlands, NJ: Greenwood Press, 1975).

Hyde, Charles, Riding the Roller Coaster: A History of the Chrysler Corporation (Detroit: Wayne State University Press, 2003).

Impey, Oliver, and Arthur MacGregor, editors, The Origins of Museums: The Cabinets of Curiosities in Sixteenth- and Seventeenth Century Europe (Oxford: Clarendon Press, 1983).

Jenkinson, Hilary, A Manual of Archive Administration (Oxford: The Clarendon Press, 1922). 
Jimerson, Randall, "American Archivists and the Search for Professional Identity," in Randall Jimerson, editor, American Archival Studies: Readings in Theory and Practice (Chicago: Society of American Archivists, 2000), 1-23.

Johnson, Arthur, "Identification of Business Records for Permanent Preservation," The American Archivist, 24:3 (July 1961), 329-32.

Johnson, Roxanne, An Analysis of the Early Record Keeping in the Du Pont Company, 1800-1818 (New York: Garland, 1989).

Jones, Arnita, and Philip Cantelon, editors, Corporate Archives and History: Making the Past Work (Malabar, Florida: Krieger Publishing Company, 1993).

Kane, Lucille, "Manuscript Collecting," in William Hesseltine, editor, In Support of Clio; Essays in Memory of Herbert A. Kellar (Madison: State Historical Society of Wisconsin, 1958), 35-36.

Kane, Lucille, "A Guide to the Care and Administration of Manuscripts," Bulletin of the American Association for State and Local History, 11:11 (September 1960), 327-88

Keller, Herbert, "Organization and Preservation of Manuscript Collections in the McCormick Historical Association Library," Public Documents with Archives and Libraries, 6 (1938), 357-64.

Kellar, Herbert, "Significance and Use of Business Archives," Proceedings of the Society of American Archivists, (1937, no volume number), 34-40.

"Kenneth M. Metcalf," Bulletin of the Special Libraries Association, Michigan Chapter," 31:2 (December 1965), 1-2.

"Kenneth M. Metcalf," Chronicle (the newsletter of the Historical Society of Michigan), 2:6 (October 1965), 2.

Kranzberg, Melvin, “At the Start.” Technology and Culture 1:1 (Winter 1959), 1-10.

Lankton, Larry, Beyond the Boundaries: Life and Landscapes at the Lake Superior Copper Mines, 1840-1875 (New York: Oxford University Press, 1997).

Lankton, Larry, Cradle to Grave: Life, Work, and Death at the Lake Superior Copper Mines (New York: Oxford University Press, 1991).

Larson, Henrietta, "Availability of Records for Research in the History of Large Business Concerns," Bulletin of the Business Historical Society, 22:1 (February 1948), 12-21. 
Larson, Henrietta, "Business Men as Collectors," Bulletin of the Business Historical Society, 18:6 (December 1944), 162-170.

Larson, Henrietta, "Ford Motor Company Archives," Bulletin of the Business Historical Society, 27:2 (June 1953), 124-125.

Larson, Henrietta, Guide to Business History: Materials for the Study of American Business History and Suggestions for Their Use (Boston: J. S. Canner, 1948).

Lathrop, Florence, “Toward a National Collecting Policy for Business History: The View from the Baker Library,” Business History Review, 62:1 (Spring 1988), 134-43.

Leahy, Emmett, “Modern Records Management," The American Archivist, 12:3 (July 1949), 231-242.

Leavitt, Thomas, "Toward a Standard of Excellence: The Nature and Purpose of Exhibit Reviews," Technology and Culture, 9:1 (January 1968), 70-75.

Leon, Warren, and Roy Rosenzweig, editors, History Museums in the United States: A Critical Assessment (Urbana: University of Illinois Press, 1989).

Lerner, Fred, The Story of Libraries: From the Invention of Writing to the Computer Age (New York: Continuum, 1999).

Lewis, David, and David Gilchrist, Economic Change in the Civil War Era: Proceedings of a Conference on American Economic Institutional Change, 1850-1873, and the Impact of the Civil War, held March 12-14, 1964, (Greenville, Delaware: Eleutherian Mills-Hagley Foundation, 1965).

Lewis, John, “Introduction," in Riggs, John, editor, Charles Wendell David: Scholar, Teacher, Librarian (Philadelphia: Union Library Catalog of the Philadelphia Metropolitan Area, 1965), 7-8.

Library of Congress and Descriptive Cataloging Division, Rules for Descriptive Cataloging in the Library of Congress: Pictures, Designs, and Other TwoDimensional Representations (Washington, D.C.: Library of Congress, 1959).

“The Life and Times of Robert M. Vogel, Ret.," SIA Newsletter, 17:3 (Fall 1988), 4-8.

Little, Cynthia, "Business History Holdings at the Historical Society of Pennsylvania," The Business History Review, 70:1 (Spring 1996), 91-107. 
Loomis, Richard, "The Telephone Comes to Washington: George C. Maynard, 18391919," Washington History, 12:2 (Fall/Winter 2000/2001), 22-40.

Lovett, Robert, “Adventures of a Business Records Hunter," March 1985, HBS Faculty Publications Files, Baker Library, Harvard Business School (GB2.535).

Lovett, Robert, "The Appraisal of Older Business Records," The American Archivist, 15:3 (July 1952), 231-239.

Lovett, Robert, "The Archivist's Book Shelf: Business Records," The American Archivist, 13:3 (1950), 303-305.

Lovett, Robert, "Arthur Harrison Cole," Proceedings of the Massachusetts Historical Society, 86 (1974), 86-89.

Lovett, Robert, "A Brief Account of the Collecting of Business Records at Harvard University," Bulletin of the Business Archives Council of Australia, (unknown date), 84-86, from the HBS Faculty Publications Files, Baker Library, Harvard Business School (GB2.535).

Lovett, Robert, "Business Manuscripts at Baker Library," Business History Review, 34:3 (Autumn 1960), 345-355.

Lovett, Robert, "Business Manuscripts at Baker Library, 1969-1979," The Business History Review, 53:3 (Autumn 1979), 386-391.

Lovett, Robert, "Business Manuscripts in the Baker Library," Harvard Library Bulletin, 5:2 (Spring 1951), 255-261.

Lovett, Robert, "Business Manuscripts in Baker Library: The Pierson Collection: Life in an Early Company Town," Bulletin of the Business Historical Society, 27:4 (December 1953), 260-263.

Lovett, Robert, "Business Records and Baker Manuscripts and Archives Department," Harvard Business School Bulletin, 57:1 (January/February 1981), 20-23.

Lovett, Robert, "Business Records in Libraries," The American Archivist, 20:3 (1957), 253-261.

Lovett, Robert, "The Case for Business History," Vermont History, 32 (January 1964), 29-35.

Lovett, Robert, List of Business Manuscripts in Baker Library (Boston, Baker Library, 1951). 
Lovett, Robert, List of Business Manuscripts in Baker Library (Boston, Baker Library, 1969).

Lovett, Robert, "Looking Around: Business Records," Harvard Business Review, (March 1951), 127-30.

Lovett, Robert, "Of Manuscripts and Archives," Special Libraries, 64 (October 1973), 415-18.

Lovett, Robert, "Recent Developments in the Care of Business Records," Bulletin of the Special Libraries Association, Business Division, 8:3 (October 1954), 1-6.

Lovett, Robert, "Some Changes in the Handling of Business Records at Baker Library," The American Archivist, 19:1 (1956), 39-44.

Lovett, Robert, "The Status of Business Archives," The American Archivist, 32:3 (July 1969), 247-250.

Lovett, Robert, and Eleanor Bishop, Manuscripts in Baker Library: A Guide to Sources for Business, Economic, and Social History (Boston: Baker Library, 1978).

Lubar, Steven, "The Computer Museum, Boston, Massachusetts," Technology and Culture, 27:1 (January 1986), 96-105.

Macmillan, David, "Business Archives: A Survey of Developments in Great Britain, The United States of America, and in Australia," in Albert Hollaendar, editor, Essays in Memory of Sir Hilary Jenkinson (Chichester, Sussex: Moore and Tillyer, 1962), 108127.

Malon, Dumas, editor, Correspondence Between Thomas Jefferson and Pierre Samuel du Pont de Nemours, 1798-1817, (New York: De Capo Press, 1930).

McCall, Emma, "Notes on Handling and Preserving Company Historical Materials," Special Libraries, 46:1 (January 1955), 16-17.

McMahon, Michal, "The Romance of Technological Progress: A Critical Review of the National Air and Space Museum.” Technology and Culture, 22:2 (April 1981), 28196.

McMahon, Michal, Technology in Industrial America: The Committee on Science and the Arts of the Franklin Institute, 1824-1900 (Wilmington, Del: Scholarly Resources, 1977). 
Mellon, De Forest, "Preserving Business Records for History, an Issue Raised by the N.R.A." Bulletin of the National Retail Dry Goods Association, 19:3 (June 1934), 1888.

"Memorial: Edwin Francis Gay," The American Economic Review, 37:3 (June 1947), $410-413$.

Moberley, Jewel, Case Studies in Records Retention and Control (New York: Controllership Foundation, 1957).

Mohr, Carolyn, Guide to the Illinois Central Archives in the Newberry Library, 18511906 (Chicago, Illinois: Newberry Library, 1951).

Molella, Arthur, "The Museum That Might Have Been: The Smithsonian's National Museum of Engineering and Industry," Technology and Culture, 32:2 (April 1991), 237-263.

Morris, Stephanie, The Franklin Institute and the Making of Industrial America: Guide to the Microfiche Collection (Bethesda, Maryland: Academic Editions, 1987).

Moss, Michael, and Lesley Richmond, "Business Records: The Prospect from the Global Village," in James O'Toole, editor, The Records of American Business (Chicago: Society of American Archivists, 1997), 369-90.

Muller, Samuel, J.A. Feith, and Robert Fruin, Manual for the Arrangement and Description of Archives (1898; first U.S. translation: New York: H.W. Wilson Company, 1968).

Multhauf, Robert P., "A Museum Case History: The Department of Science and Technology of the United States Museum of History and Technology," Technology and Culture, 6:1 (Winter 1965), 47-58.

Nash, Michael, "Business History and Archival Practice," in J O'Toole, editor, The Records of American Business (Chicago: Society of American Archivists, 1997), 1140.

Nash, Michael, "Business History at the Hagley Museum," Business History Review, 60:1 (Spring 1986), 104-120.

Nash, Michael, John Rumm, and Craig Orr, Pennsylvania Power \& Light Company: A Guide to the Records (Wilmington, Delaware: Hagley Museum and Library, 1985). 
National Fire Protection Association and Committee on Protection of Records, Protection of Records: Consolidated Reports of the Committee on Protection of Records.

(Boston, Massachusetts: National Fire Protection Association, 1935).

National Museum of History and Technology, Guide to Manuscript Collections in the National Museum of History and Technology, 1978 (Washington: Smithsonian Institution Press, 1978).

National Records Management Council, Index to Federal Record Keeping Requirements (New York: National Records Management Council, 1955).

Nesmith, Tom, "Seeing Archives: Postmodernism and the Changing Intellectual Place of Archives," The American Archivist, 65:1 (Spring/Summer 2002), 24-41.

Nevins, Allan, and Frank Hill, Ford: The Times, the Man, and the Company (New York: Scribner, 1954).

Nevins, Allan, and Frank Hill, Ford: Expansion and Challenge, 1915-1933 (New York: Scribner, 1957).

Nevins, Allan, and Frank Hill, Ford: Decline and Rebirth, 1933-1962 (New York: Scribner, 1963).

“News and Comment," Pennsylvania History, 43:2 (1976), 186.

Norton, Margaret, "Herbert Anthony Kellar, 1887-1955." The American Archivist, 19:2 (April 1956), 151-53.

Olson, Sidney, Young Henry Ford: A Picture History of the First Forty Years (Detroit: Wayne State University Press, 1997).

"Oral Reminiscence of Winthrop Sears Jr. Concerning the Henry Ford Archives in the 1950's and 1960's as told to Ann Flowers, one of his daughters," 1996 (copy at Benson Ford Research Center, The Henry Ford).

Orbell, John, “The Development of Office Technology," in Alison Turton, Managing Business Archives (Oxford, England: Butterworth-Heinemann, 1991), 60-83.

O’Toole, James, "The History of the Archives Profession," in James O’Toole, Understanding Archives and Manuscripts, 27-47.

O'Toole, James, editor, The Records of American Business (Chicago: Society of American Archivists, 1997). 
O’Toole, James, Understanding Archives and Manuscripts (Chicago: Society of American Archivists, 1990).

Overman, William, "The Firestone Archives and Library." The American Archivist, 16:4 (October 1953), 305-9.

Overman, William, "The Pendulum Swings," The American Archivist, 22:1 (January 1959), 3-10.

Overton, Richard, "Can the Records Manager Help the Business Historian?" The Business History Review, 29:3 (September 1955), 211-17.

Parks, Jim, "A Sense of Corporate History: Hagley Museum and Library is the Nation's Foremost Depository of Corporation Archives," Focus: Metropolitan Philadelphia's Business Newsweekly, (July 19, 1989), 18-21.

Parks, Ruth, "The National Safety Council Archives," Special Libraries, 46:1 (January 1955), 11-13.

Paul, Karen Dawley, "Archivists and Records Management," in James Bradsher, editor, Managing Archives and Archival Institutions (Chicago: University of Chicago Press, 1988), 34-52.

Pederson, Ann, "Analysis or Prescription? Richard Berner on Archival Theory and Practice," The Midwestern Archivist, 9:1 (1984), 35-43.

Porter, Glenn, The Workers' World at Hagley (Wilmington, Delaware: Hagley Museum and Library, 1981).

Posner, Ernst, American State Archives (Chicago: University of Chicago Press, 1964).

Post, Robert, “A Life With Trains," American Heritage Invention and Technology, 6:2 (Fall 1990), 34-40.

Post, Robert, "A Very Special Relationship:" SHOT and the Smithsonian's Museum of History and Technology," Technology and Culture, 42:3 (July 2001), 401-435.

Pursell, Carroll, "The History of Technology and the Study of Material Culture," American Quarterly, 35:3 (January 1983), 304-15.

Reeves, Dorothea D., Resources for the Study of Economic History: A Preliminary Guide to Pre-Twentieth Century Printed Material in Collections Located in Certain American and British Libraries (Boston: Baker Library, Harvard Graduate School of Business Administration, 1961). 
Reynolds, Terry, and Virginia Dawson, Iron Will: Cleveland-Cliffs and the Mining of Iron Ore, 1847-2006 (Detroit: Wayne State University Press, 2011).

Rich, George, “Our Primary Purpose.” Bulletin of the Business Historical Society, 1:1 (June 1926), 1-2.

Richmond, Lesley, and Bridget Stockford, Company Archives: A Survey of the Records of 1000 of the First Registered Companies in England and Wales (Aldershot, England: Gower, 1986).

Richmond, Lesley, and Alison Turton, Directory of Corporate Archives: A Guide to British Businesses Which Maintain Archive Facilities (London: Business Archives Council, 1997).

Riggs, John, A Guide to the Manuscripts in the Eleutherian Mills Historical Library: Accessions through the Year 1965 (Greenville, Delaware: Eleutherian Mills Historical Library, 1970).

Riggs, John, A Guide to Manuscripts in the Eleutherian Mills Historical Library: Supplement Containing Accessions for the Years 1966 through 1975 (Greenville, Delaware: Eleutherian Mills Historical Library, 1970).

Riggs, John, editor, Charles Wendell David: Scholar, Teacher, Librarian (Philadelphia: Union Library Catalog of the Philadelphia Metropolitan Area, 1965).

Rink, Evald, Printing in Delaware, 1761-1800 (Wilmington, Delaware: Eleutherian Mills Historical Library, 1969).

Rink, Evald, Technical Americana: A Checklist of Technical Publications Printed Before 1831 (Millwood, New York: Kraus International Publications, 1981).

Robbins, Caroline, “The First Half Century," in Riggs, John, editor, Charles Wendell David: Scholar, Teacher, Librarian (Philadelphia: Union Library Catalog of the Philadelphia Metropolitan Area, 1965), 10-18.

Roe Smith, Merritt, "Toward a Standard of Excellence: The Second Installment," Technology and Culture, 15:1 (January 1974), 76-79.

Rounds, Jay, "Is There a Core Literature in Museology?," Curator, 44:2 (April 2001), 194-206.

Rounds, Jay, "On the Uses of Museum Studies Literature: A Research Agenda," Curator, 50:1 (January 2007), 135-146. 
Rubin, Richard, Foundations of Library and Information Science (New York: Neal Schuman, 1998).

Rules Governing Use of Ford Motor Company Archives (Bulletin No. 2) (Dearborn, Michigan: Ford Motor Company, 1953).

Saretzky, Gary, "North American Business Archives: Results of a Survey," The American Archivist 40:4 (October 1977), 413-19.

Saretzky, Gary, "Oral History in American Business Archives," The American Archivist, 44:4 (Fall 1981), 353-55.

Schellenberg, Theodore, Modern Archives; Principles and Techniques. (Chicago, University of Chicago Press, 1956).

Schellenberg, Theodore, The Management of Archives (New York, Columbia University Press, 1965).

Schlatter, Elizabeth, Museum Careers: A Practical Guide for Students and Novices (Walnut Creek, California: Left Coast Press, 2008).

Schulz, Constance, American Historical Association, and National Council on Public History, Careers for Students of History (Washington, D.C.: American Historical Association, 2002).

Scranton, Philip, "Diversity in Diversity: Flexible Production and American Industrialization, 1880-1930,” Business History Review, 65:1 (April 1991), 27-90.

Schwantes, Carlos, Vision \& Enterprise: Exploring the History of Phelps Dodge Corporation (Phoenix: University of Arizona Press, 2000).

Seely, Bruce, "SHOT, the History of Technology, and Engineering Education," Technology and Culture, 36:4 (October 1995), 739-72.

Shiff, Robert, "The Archivist's Role in Records Management," The American Archivist, 19:2 (1956), 111-20.

Sinclair, Bruce, Philadelphia's Philosopher Mechanics; a History of the Franklin Institute, 1824-1865 (Baltimore, Johns Hopkins University Press, 1974).

Singer, Charles, et al., editors, A History of Technology, 5 vols. (Oxford: Clarendon Press, 1954). 
Skramstad, Harold, "The Mission of the Industrial Museum in the Postindustrial Age," The Public Historian, 22:3 (Summer 2000), 25-32.

Slaff, Allan, "Organization and Operation of Baker Library," in Abraham Zaleznik, et al., editors, Baker Library and the Harvard Business School (Boston, Massachusetts: Harvard University, Graduate School of Business Administration, 1978), 31-51.

Smith, David, "A Historical Look at Business Archives," The American Archivist, 45:3 (Summer 1982), 273-278.

Smith, Jerome, "Preliminary Guide to the Manuscript Collections in the Robert H. Tannahill Research Library, Greenfield Village and Henry Ford Museum," undated, copy in Reading Room Reference Collection, Benson Ford Research Center, The Henry Ford.

Smith, Jerome, "Robert Hudson Tannahill Research Library," The Herald (publication of The Edison Institute), 3:3 (July 1974),

Smulyan, Susan, “America’s Smithsonian.” The Public Historian, 19: 3 (July 1997), 8791.

Society of American Archivists, Directory of Business Archives in the United States and Canada (Chicago: The Society, 1975).

Soltow, James, "The Business Use of Business History," The Business History Review, 29:3 (September 1955), 227-37.

Sullivan, Peggy, “Library Associations,” Library Trends, 25:1 (July 1976), 135-152.

Swanson, Duane and Hugh Gibb, The Historical Records of the Components of Conrail: A Survey and Inventory (Greenville, Delaware: Eleutherian Mills Historical Library, 1978).

Sward, F. L., "Business Records Management," The American Archivist, 29:1 (January 1966), 69-74.

“Symposium: Company Archives,” Special Libraries, 46:1 (January 1955), 7.

Taylor, Frank, Catalog of the Mechanical Collections of the Division of Engineering, United States National Museum (Bulletin 173) (Washington, U.S. Government Printing Office, 1939), 13-20.

Taylor, Frank, "The Background of the Smithsonian's Museum of Engineering and Industries," Science, 104:2693 (August 9, 1946), 130-132. 
Taylor, Graham D., and Patricia E. Sudnik, Du Pont and the International Chemical Industry (Boston, Massachusetts: G.K. Hall, 1984).

Turton, Alison, Managing Business Archives (Oxford, England: Butterworth-Heinemann, 1991).

Upward, Geoffrey, A Home for Our Heritage: The Building and Growth of Greenfield Village and Henry Ford Museum, 1929-1979 (Dearborn, Michigan: Henry Ford Museum Press, 1979).

Vogel, Robert, "A Collection of Early Steam Engine Drawings," The Smithsonian Journal of History, 1:4 (Winter 1967), 75-76.

Vogel, Robert, “Assembling a New Hall of Civil Engineering," Technology and Culture, 6:1 (Winter 1965), 59-73.

Vogel, Robert, “The Prehistory of HAER, 1965-1968,” CRM, 23:4 (2000), 5-7.

Wallace, Anthony, St. Clair: A Nineteenth-Century Coal Town's Experience with a Disaster-prone Industry (New York: Knopf, 1987).

Wamsley, James, American Ingenuity: Henry Ford Museum and Greenfield Village (New York: Henry Abrams, 1985).

Warren, Kenneth, Big Steel: The First Century of the United States Steel Corporation (Pittsburgh: University of Pittsburgh Press, 2001).

Watts, Steven, The People's Tycoon: Henry Ford and the American Century (New York: Knopf, 2006).

Weil, Stephen, Rethinking the Museum and Other Meditations (Washington, D.C.: Smithsonian Institution, 1990).

Weisz, Jackie, Codes of Ethics and Practice of Interest to Museums (Washington, D.C.: American Association of Museums, 2000).

Williams, Richmond, "Eleutherian Mills Historical Library," Manuscripts, 14:2 (Spring 1962), 38-41.

White, John, “The Railway Museum: Past, Present, and Future.” Technology and Culture, 14: 4 (October 1973), 599-613. 
Williams, Richmond, "The Longwood Achievement," in John Riggs, editor, Charles Wendell David: Scholar, Teacher, Librarian (Philadelphia: Union Library Catalog of the Philadelphia Metropolitan Area, 1965), 46-53.

Williamson, Harold, editor, Evolution of International Management Structures (Newark: University of Delaware Press, 1975).

Winkler, John K., The Du Pont Dynasty (New York: Reynal \& Hitchcock, 1935).

"Winthrop Sears (1918-2000)," Open Entry (newsletter of the Michigan Archival Association), 29:1 (Spring 2001), 11.

Wohl, Richard, "The Significance of Business History," The Business History Review, 28:2 (June 1954), 128-40.

Wolfsberg, Vernie, "Building Company Archives," Special Libraries, 46:1 (January 1955), 13-15.

Wolfsberg, Vernie, Review of Fair Lane; Ford Motor Company Archives; Rules Governing the Use of Ford Motor Company Archives; Ford Documents and Photographs; An Exhibit (Fair Lane); Speaking of Yesterday; An Explanation of the Ford Motor Company Archives Oral History Project, The American Archivist, 16:4 (October 1953), 354-55.

Wright, Helena, "Insurance Mapping and Industrial Archaeology," IA, 9:1, (1983), 1-18.

Yates, JoAnne, Control Through Communication: The Rise of System in American Management (Baltimore: Johns Hopkins University Press, 1989).

Yates, JoAnne, "Internal Communication Systems in American Business Structures: A Framework to Aid Appraisal," The American Archivist, 48:2 (Spring 1985), 141-58.

Yeager, Mary, "Mavericks and Mavens of Business History: Miriam Beard and Henrietta Larson," Enterprise and Society, 2:4 (December 2001), 687-768.

Zaleznik, Abraham, et al., editors, Baker Library and the Harvard Business School (Boston, Massachusetts: Harvard University, Graduate School of Business Administration, 1978).

Zilg, Gerald Colby, Du Pont: Behind the Nylon Curtain (Englewood Cliffs, New Jersey: Prentice-Hall, 1974).

Zitmore, Irving, "How to Decide Whether to Microfilm Business Records and How to Go About It," Journal of Accountancy, 40:2 (February 1951), 276-281. 


\section{Manuscript collections}

Note: This section is limited to the significant groups of administrative records and personal papers which document the internal operations of each case study institution. It does not include references to all of the individual business collections held at each institution; please see footnotes in the case study chapters for specific information.

Abbreviations:

HBS Archives - Baker Library, Harvard Business School.

BFRC - Benson Ford Research Center, The Henry Ford.

EMHFA/RG4 - See reference under Hagley Museum and Library below.

EMHFA/RG5 - See reference under Hagley Museum and Library below.

Baker Library, Harvard Business School, Boston, Massachusetts.

HBS Faculty Biography Files. HBS Faculty Publications Files. HBS Archives Vertical Files. Business Historical Society Records, HBS Archives.

Benson Ford Research Center, The Henry Ford, Dearborn, Michigan.

Accession E.I. \#57, Frank Caddy Records.

Accession E.I. \#156, Henry Ford Museum Planning and Construction Records. Accession E.I. \#195, Douglas A. Bakken Records. Accession E.I. \#1929, Edison Institute Photographs. Accession 365, Ford Motor Company Fiftieth Anniversary Reports. Accession 506, Mills, Edmunds and Nevins and Hill Series. Accession 536, Press Release Subseries, FMC Public Relations Series. Accession 895, Winthrop Sears Records Series. Accession 906, Archives Reports Subseries. Archives Vertical Files.

Hagley Museum and Library, Wilmington, Delaware.

Eleutherian Mills Hagley Foundation Archives. Record Group IV, Longwood Library (EMHFA/RG4).

Record Group V, Library (EMHFA/RG5).

Archives Center, National Museum of American History, Smithsonian Institution, Washington D.C.

Archival Collections Administrative History Files. 
Smithsonian Institution Archives, Smithsonian Institution, Washington D.C.

Record Unit 276, National Museum of History and Technology, Office of the Director, Records.

Record Unit 334, National Museum of American History, Office of the Director, Subject Files.

Record Unit 397, National Museum of American History, Division of Engineering and Industry, Records.

Accession T90005, National Museum of American History, Department of History of Science, Records.

Accession T90006, National Museum of History and Technology, Department of History of Technology, Correspondence and Memoranda.

\section{Personal interviews}

Endelman, Judith, July 25, 2016

Finn, Bernard, February 15, 2010 (email)

Finn, Bernard, March 1, 2010

Fleckner, John, March 4, 2009

Fleckner, John, March 1, 2010

Fleckner, John, September 14, 2010 (e-mail)

Hoover, Terry, July 29, 2016

Hyde, Charles, August 4, 2010

Mein, Nardina, July 1, 2016

Miller, Cynthia Read, August 12, 2016

Skramstad, Harold, July 30, 2014

Spence, Theresa, August 96, 2009

Szary, Richard, May 14, 2010

Vogel, Robert, May 30, 2009

Vogel, Robert, March 5, 2010

White, John, April 5, 2010

Wilson, Brian, July 25, 2017, (e-mail) 


\section{Internet sources}

Note: This bibliography omits references to online versions of the finding aids referenced in footnotes in the case study chapters.

Bailey, Courtney, "Identify In Flux: The Evolution of the Selection and Retention of Business Records," April 24, 2012, https://cbaileymsls.files.wordpress.com/2015/04/ 755_business-records.pdf, accessed February 1, 2017.

Business Archives Council (Great Britain), "About the Business Archives Council," http://www.businessarchivescouncil.org.uk/about/aboutintro/, accessed February 8, 2017.

"David Gilchrist," The Day (New London, Conn.), September 9, 2011, http://www.legacy.com/obituaries/theday/obituary.aspx?pid=153522898, accessed October 13, 2015.

"Early Writing," Harry Ransom Center, University of Texas at Austin, http://www.hrc. utexas.edu/educator/modules/gutenberg/books/early/, accessed February 16, 2017.

"Frank Taylor; Founding Director of American History Museum," Washington Post, June 30, 2007, http://www.washingtonpost.com/wp-dyn/content/article/2007/06/29/ AR2007062902435.html, accessed April 23, 2017.

"Frank Taylor; Influential public servant and administrator who steered the postwar expansion and modernization of the Smithsonian," The Sunday Times (New York), July 30, 2007, http://www.timesonline.co.uk/tol/comment/obituaries/article2163431.ece, accessed April 27, 2010.

"History of the ARMA International Educational Foundation," https://www.arma.org/aief/who-we-are/history, accessed February 9, 2017.

National Museum of American History, "Mission \& History," http://americanhistory.si.edu/museum/mission-history, accessed April 23, 2017.

"Photographer to the World," http://ophelia.sdsu.edu:8080/henryford_org/12-082013/exhibits/dpc/everyday/about.asp.html, accessed November 28, 2016.

"Powering A Generation: Finn Biography," http://americanhistory.si.edu/powering/bios/finn.htm, accessed April 23, 2017.

"Richmond Dean Williams," (obituary), The News Journal (Wilmington, Delaware), October 25, 2014, http://www.legacy.com/obituaries/delawareonline/obituary .aspx?pid=172927963, accessed November 15, 2014. 
Smithsonian Institution Archives, "A Brief History of the Smithsonian Institution Archives," http://www.siarchives.si.edu/sia/main_about.html, accessed April 18, 2010.

Smithsonian Institution Archives, “Agency History, 1957-present," National Museum of American History, https://siarchives.si.edu/collections/siris_arc_218078, accessed May 9, 2017.

Smithsonian Institution Archives, “Agency History, 1957-present," National Museum of American History, Division of Agriculture and Natural Resources, https://siarchives.si.edu/collections/siris_arc_222941 accessed May 9, 2017.

Society of American Archivists, "Business Archives: Establishing and Managing an Archives," http://www2.archivists.org/prof-education/course-catalog/business-archives\%E2\%80\%A6-establishing-and-managing-an-archives, accessed September 2, 2017.

Society of American Archivists, "Directory of Corporate Archives in the United States and Canada," https://www2.archivists.org/groups/business-archives-section/directory-ofcorporate-archives-in-the-united-states-and-canada-introduction, accessed February 8, 2017.

Society of American Archivists, "History of SAA Leadership," http://www2.archivists.org/history/leaders, accessed November 19, 2015. 